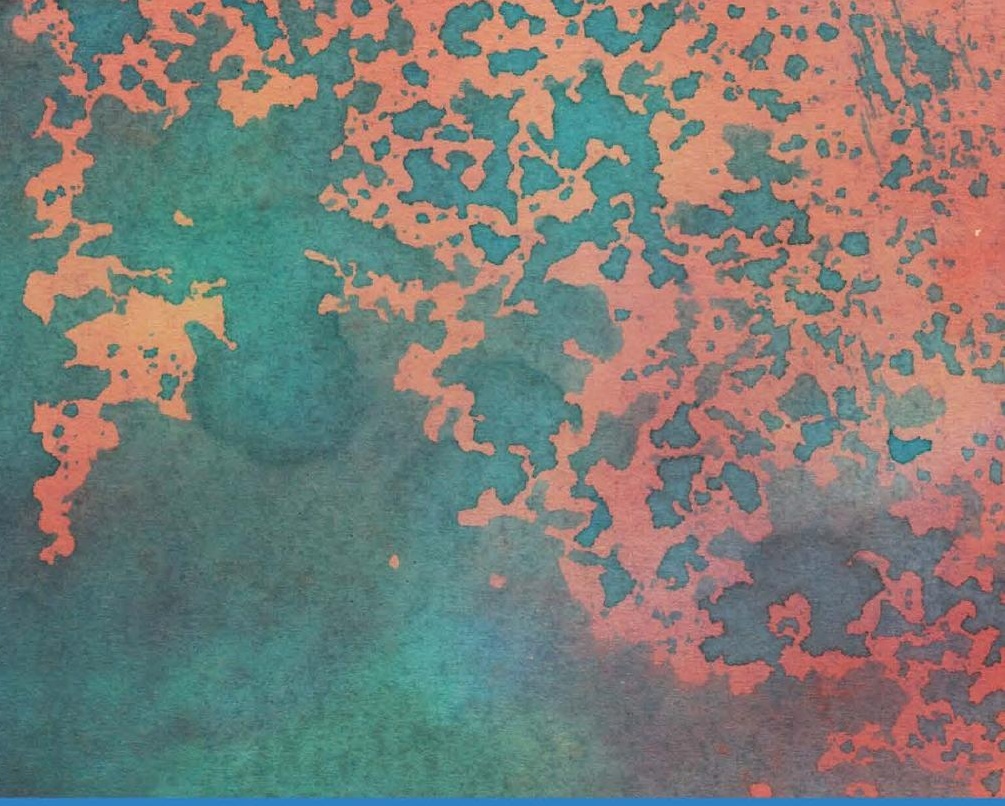

Routledge Studies in Anthropology

\title{
HUMAN EXTINCTION AND THE PANDEMIC IMAGINARY
}

Christos Lynteris

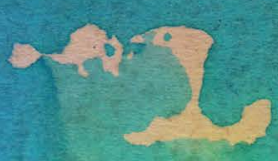




\section{Human Extinction and the Pandemic Imaginary}

Nested in debates in anthropology, philosophy, social theory and global health, the book argues that fear of and fascination with the "next pandemic" stem not so much from an anticipation of a biological extinction of the human species, as from an expectation of the loss of mastery over human/non-human relations. Christos Lynteris employs the notion of the "pandemic imaginary" in order to understand the way in which pandemic-borne human extinction refashions our understanding of humanity and its place in the world. The book challenges us to think how cosmological, aesthetic, ontological and political aspects of pandemic catastrophe are intertwined. The chapters examine the vital entanglement of epidemiological studies, popular culture, modes of scientific visualisation, and pandemic preparedness campaigns. This volume will be relevant for scholars and advanced students of anthropology as well as global health, and for many others interested in catastrophe, the "end of the world" and the (post)apocalyptic.

Christos Lynteris is Senior Lecturer in Social Anthropology at the University of St Andrews, UK. His books for Routledge include Plague and the City (2018) and The Anthropology of Epidemics (2019). 


\section{Routledge Studies in Anthropology}

\section{Hybrid Communities}

Biosocial Approaches to Domestication and Other Trans-species Relationships

Edited by Charles Stépanoff and Jean-DenisVigne

Orthodox Christian Material Culture

Of People and Things in the Making of Heaven

Timothy Carroll

Bureaucracy, Integration and Suspicion in the Welfare State

Mark Graham

\section{Slogans}

Subjection, Subversion and the Politics of Neoliberalism

Edited by Nicolette Makovicky, Anne-Christine Trémon, and Sheyla S. Zandonai

\section{Security Blurs}

The Politics of Plural Security Provision

Edited by Tessa Diphoorn and Erella Grassiani

Cultural Models of Nature

Primary Food Producers and Climate Change

Edited by Giovanni Bennardo

Guatemalan Vigilantism and the Global (Re)Production of Collective Violence

A Tale of Two Lynchings

Gavin Weston

\section{Human Extinction and the Pandemic Imaginary}

Christos Lynteris

For more information about this series, please visit: www.routledge.com/ Routledge-Studies-in-Anthropology/book-series/SE0724 


\section{Human Extinction and the Pandemic Imaginary}

Christos Lynteris

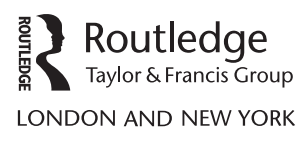


First published 2020

by Routledge

2 Park Square, Milton Park, Abingdon, Oxon OX14 4RN

and by Routledge

52 Vanderbilt Avenue, New York, NY 10017

Routledge is an imprint of the Taylor \& Francis Group, an informa business

(C) 2020 Christos Lynteris

The right of Christos Lynteris to be identified as author of this work has been asserted by him in accordance with sections 77 and 78 of the Copyright, Designs and Patents Act 1988.

All rights reserved. No part of this book may be reprinted or reproduced or utilised in any form or by any electronic, mechanical, or other means, now known or hereafter invented, including photocopying and recording, or in any information storage or retrieval system, without permission in writing from the publishers.

Trademark notice: Product or corporate names may be trademarks or registered trademarks, and are used only for identification and explanation without intent to infringe.

\section{British Library Cataloguing-in-Publication Data}

A catalogue record for this book is available from the British Library

Library of Congress Cataloging-in-Publication Data

Names: Lynteris, Christos, author.

Title: Human extinction and the pandemic imaginary / Christos Lynteris.

Description: Milton Park, Abingdon, Oxon ; New York, NY :

Routledge, 2020. | Series: Routledge studies in anthropology | Includes bibliographical references and index.

Identifiers: LCCN 2019029081 (print) | LCCN 2019029082 (ebook) |

ISBN 9780367338145 (hardback) | ISBN 9780429322051 (ebook)

Subjects: LCSH: Epidemics. | Extinction (Biology) | Biological disasters.

Classification: LCC RA651 .L96 2020 (print) | LCC RA651 (ebook) | DDC 614.4/9-dc23

LC record available at https://lccn.loc.gov/2019029081

LC ebook record available at https://lccn.loc.gov/2019029082

ISBN: 978-0-367-33814-5 (hbk)

ISBN: 978-0-429-32205-1 (ebk)

Typeset in Times New Roman

by Apex CoVantage, LLC 
To my parents, Emily and Dimitris 


\section{Contents}

List of figures viii

List of tables ix

Preface and Acknowledgments $\quad \mathrm{x}$

Introduction: the end of mastery 1

1 The end of the world as we do not know it 24

2 Zoonotic transformations 42

3 Anthropogenesis reversed $\quad 77$

4 The epidemiologist as culture hero 99

5 The post-pandemic condition 118

$\begin{array}{ll}\text { Conclusion: catastrophism beyond closure } & 136\end{array}$

$\begin{array}{lr}\text { Bibliography } & 145\end{array}$

Index 172 


\section{Figures}

2.1 "The New Plague: We're one mutation from the end of the world as we know it" (New Scientist cover, May 9, 2015)

2.2 An example of zoonotic cycles applied to plague in contemporary studies

2.3 Ben Ari et al.'s zoonotic cycles model of plague; note interlaps between different "cycles" (Ben Ari et al. 2011) 52

2.4 "Spidergram" showing Ebola spillover drivers (EFSA 2015) 60

3.1 Diagram comparing Promethean and anti-Promethean transmission and transformation

4.1 US CDC poster accompanying "Zombie Preparedness 101" campaign, 2011 


\section{Tables}

4.1 Zombie Containment Pathways in World War Z (USA and UK, 2013) 


\section{Preface and acknowledgments}

This book does not examine the past so as to understand the present, or indeed the other way around, but considers the present and the past together, as the past participle of what is not yet. Rather than amounting to an archaeology of the future, however, this study focuses on a conjugation that leads to the erasure of any future, understood as a time of human agency: the "next pandemic". To understand how the past and the present are rendered into the anteroom of an eternal nofuture, the prelude to human extinction, has required me to engage with material and methods hitherto at the edge of sight as far as my research, both ethnographic and historical, is concerned. It all started as a sideways gaze, taken at leisurely breaks from archival work for my research on the emergence of epidemic photography at the turn of the nineteenth century: a film here, a video game there, the cover of yet another feature on the existential threat posed by a killer virus. Then came a film that, even in the censored, airplane version that was the first one I watched, immediately appeared to condense in all its unbearable banality a series of anthropological transformations, which in turn illuminated the historical material I was examining: World War Z. What started as an obsession with dissecting the anthropological heart of this zombie Hollywood blockbuster quickly grew into a systematic examination of how scientific outputs and public health policies interlink and form a unified field of signification with what is generally seen as "pop" forms and practices of pandemic-threat consumption. Catching up with developments relating to this pandemic triangle (science, policy, popular culture) soon developed into a race that many times appeared futile. Every month, new films, TV series, popular science articles, computer games, or smartphone apps like "BBC Pandemic" would come up to add new elements to the way in which the next pandemic became entangled with anticipations, fears, and fantasies of human extinction. At the same time, the Ebola epidemic of 2014-2016 led to a surge in scientific interest in infectious disease emergence and fear of a global pandemic drove global health policy, like the 2009 swine flu scare and the 2003 SARS outbreak had done before. Not coincidentally, during this period (roughly October 2013 to September 2018), the anthropological study of infectious diseases witnessed an impressive development, so that today what we may call the anthropology of epidemics forms a substantial corpus of work beyond the sum of individual ethnographies about specific outbreaks in different locations on 
the globe. I have been fortunate to collaborate in diverse ways over the past eight years with champions of this new wave of anthropological theory and practice: Frédéric Keck, Carlo Caduff, Ann Kelly, Alex Nading, Hannah Brown, Natalie Porter, Genese Sodikoff, and others. If in Human Extinction and the Pandemic Imaginary I opt to not summarize these works, this is so as to focus more on developing links between them and other fields of scholarship and spheres of critique that have remained relatively undeveloped in medical anthropology.

The principal strategy of this book consists in building meaningful bridges between anthropology, history, literary and film studies, theology, the classics, and political philosophy on the relation between pandemics, the imaginary, and existential risk. Doing so runs the risk of the result appearing eclectic or "intellectualist". In the process of completing the book and presenting its chapters to seminars across universities and disciplines, I have sometimes been confronted with what we may call disciplinary "suspicion": Why do I take cultural products like pandemic films or video games so seriously? Surely, they are just entertainment ephemera that should not be considered as having the same gravity as scientific works or policy documents. And, on the other hand, why confuse my audience with bookish references to Galenic medicine, Greek tragedy, or Paulian eschatology when the phenomenon I am studying is twenty-first-century visions of the end? When combined, the two critiques may indeed lead one to wonder: Are not the raw material of this book too ephemeral and its analytical toolkit too highbrow? Do we really need to examine the relation between Thucydides' notion of anomy and Paul's vision of the apocalypse to understand video games like The Last of Us? And can films like I Am Legend really contribute to our understanding of contemporary attitudes toward autopoiesis? I hope this book will convince its readers that what is needed in order to understand the "pandemic imaginary" is not a presentist "close reading" but rather a telescopic vision of the way in which we negotiate humanity today in the West: as a process of projecting its end in the future through the use of visual and discursive tools forged and transformed in the near and long-distanced past.

In thus drawing what may be called a troubled genealogy of humanity's nonfuture, this book is primarily the result of reflections on contemporary material, rag-picked in the process of my research with historical material relating to the third plague pandemic (1894-1959) - the first pandemic in human history to be captured by the photographic and then cinematographic lens and to set mechanical representations at the center of new ways of knowing and acting upon epidemic crises. Punctuating this examination is the study of interlaced fields of vision. If the notion of the pandemic and the worldview this created arose out of human efforts to understand and cope with the third plague pandemic at the turn of the nineteenth century, pandemic-borne human extinction and its accompanying world and worldview are hallmarks of the era of emerging infectious diseases. Both the emergence of pandemic frameworks and their transformation into frameworks of human extinction depend not only on epistemological shifts of understanding disease but also, and pertinently, on the visual configuration of these shifts into new regimes of truth that are able to span scientific, governmental, and 
popular cultures. If this book is not a study of visual culture, it returns time and again to shifting pandemic fields of vision, as these provide a unique window into the transformations of the imaginary that is the proper object of this study.

Human Extinction and the Pandemic Imaginary was written as an unexpected result of my research as the Principal Investigator of the Visual Representations of the Third Plague Pandemic project at the Centre for Research in the Arts, Humanities and the Social Sciences of the University of Cambridge and the Department of Social Anthropology of the University of St Andrews. I would like to thank Lukas Engelmann, Branwyn Poleykett, Nicholas Evans, Abhijit Sarkar, and Maurits Meerwijk for ideas and critiques of my approach of epidemic representation and Emma Hacking, Teresa Abaurrea, Samantha Peel, and Catherine Hurley for their tireless help with my project.

I would also like to thank colleagues and friends who have taken up the time to read different parts of the book at different stages of its development. In particular, I would like to thank David Napier for his eagerness to discuss everything, from contagious zombies and superspreaders to beaked-masked plague doctors over the course of many years. I would also like to thank Frédéric Keck for undertaking together an ongoing journey to the philosophical eschata of zoonosis and its anthropological significance, and Ruth Prince and Carlo Caduff for their thoughts about the next pandemic and prophetic photography. I would like to thank Lukas Engelmann and Caroline Humphrey for an ongoing exchange on diagrams and Boris Schimdt, Michael Kosoy, Michelle Ziegler, Matei Candea, Ann Kelly, Hannah Brown, and Elizabeth Hallam for their input in my understanding of zoonotic diagrams. I would also like to thank Carlo Severi and Nigel Rapport for their feedback on my take on the imaginary and imagination, Joel Robbins for patiently listening to and responding to my musings about the apocalyptic, Elizabeth Edwards for her encouragement in my photographic exploration of epidemics, Alex Taylor for generous discussions of existential risk and its filmic representations, and Marc Berdet for his invaluable advice on Walter Benjamin's approach of mastery.

Parts of Chapter 2 have been previously published in "Zoonotic Diagrams: Mastering and Unsettling Human-Animal Relations" in the Journal of the Royal Anthropological Institute (2017) and "The Prophetic Faculty of Epidemic Photography: Chinese Wet Markets and the Imagination of the Next Pandemic" in the journal Visual Anthropology (2016): 118-132. In both cases, the text has been revised and updated. Chapter 5 was previously published as "The Epidemiologist as Culture Hero: Visualizing Humanity in the Age of "the Next Pandemic" in Visual Anthropology (January 2016), 29(1): 36-53. The text has been revised and updated.

\section{Funding information}

Research leading to this book was funded by a European Research Council Starting Grant (under the European Union's Seventh Framework Programme/ ERC grant agreement no. 336564) for the project Visual Representations of the Third Plague Pandemic (University of Cambridge and University of St Andrews, 2013-2018). 


\section{Introduction}

\section{The end of mastery}

"A typical person is more than five times as likely to die in an extinction event as in a car crash". ${ }^{1}$ The statement, from a headline in The Atlantic, appears to be at first sight frivolous, if only for the way in which so many generalizations are packed in such a short sentence. Still, we should not be misled to overlook the idea underscoring it, which is none other than the imminence of human extinction as both a population-level event and a personal eventuality.

In recent years, an increasing interest in human extinction has given rise not only to bestselling novels, blockbuster Hollywood films, and computer games but also to preparedness policies, major research programs, and think tanks, including lavishly funded centers dedicated to the study of existential risk at Oxford and Cambridge. ${ }^{2}$ At the same time, the "end of the world" has become a prolific basis for works by and exchanges between philosophers, anthropologists, and social theorists. ${ }^{3}$ This corpus has developed in response to climate change, and more broadly the idea of the Anthropocene, as well as to the impact of more immediate disasters like the one brought about by the 2011 earthquake in Fukushima, whose consequences continue to unfold eight years later. Engaging in catalytic ways with current political and ecological debates, these works have rekindled questions posed at the height of Cold War nuclear anguish by philosophers like Günther Anders and Hans Jonas. ${ }^{4}$ Key to the overall discussion has been the relation between humans and the world and, in particular, the way in which different "ends of the world" configure humankind as an "entity for whom the world is a world, or rather, whose world the world is". 5

Situated in the "in between" of the political, philosophical, and anthropological fault lines of this question, Human Extinction and the Pandemic Imaginary develops a critical approach of human extinction as a key component of what Déborah Danowski and Eduardo Viveiros de Castro have called "mythical variations of the end of the world". 6 In particular, it examines an "end of the world" variant that raises key anthropological questions about human extinction, insofar as, being the sole variant that assumes the source of the "end" to be terrestrial nonhuman life, it challenges mastery as the ontological foundation of being human. This is none other than the "next pandemic" - the anticipated-asinevitable event of human extinction in the hands, or rather spikes, of a "successful zoonotic pathogen". ${ }^{7}$ 


\section{Introduction}

Neil Gerlach and Sheryl Hamilton have recently argued that what they call "pandemic culture" becomes "constituted, not in the proliferation of pandemics as medical phenomena, but in the explosion of communication about imagined, potential pandemics". 8 Taking a critical distance from the notion of "culture" and seeking to forge a critical theoretical approach of human extinction, the aim of this book is to examine the way in which ideas, policies, anticipations, and representations of the next pandemic comprise what I call the "pandemic imaginary". It is through this notion that the book will seek answers to how is humanity configured and transformed when we consider it from the vantage point of its disappearance. ${ }^{9}$

\section{Transformations of extinction}

Over the past decade, proliferating concerns about the impact of climate change as well as the notion of the Anthropocene, as an age where the Earth's very geology is formed by human activity, have increasingly led anthropologists to approach the subject of species extinction from various analytical and critical perspectives. In her introduction to The Anthropology of Extinction, a work that may be considered as the leading volume on the subject so far, Genese Sodikoff frames this interest within the broader narrative of the "sixth extinction" ${ }^{10}$ The idea - conceptually traced back to biologist Norman Myers - was first coined by Richard Leakey and Roger Lewin in a homonymous book published in $1995 .{ }^{11}$ It has since been employed in works ranging from Pulitzer-awarded popular science books to fiction bestsellers and science fiction spectacles, so as to become the staple of newspapers and magazines. ${ }^{12}$ Put simply, the "sixth extinction" revolves around the idea that life on Earth is undergoing a new transformative process similar to the one that 66 million years ago led to the end of the dinosaurs - with the difference that "the sixth extinction is neither abrupt nor spectacular" and "not defined by a steep reduction of all life on Earth but rather by a reduction in the abundance and diversity of macroscopic life". ${ }^{13}$ This is then seen as a gradual but, at the same time, accelerating (and by some irreversible) process through which humanity's impact on the planet is leading "in a compressed timeframe" to the extinction of an ever larger number of species and, most crucially, to a critical demise in biodiversity as a whole. ${ }^{14}$ Rather than being an event that is simply projected to the future, the sixth extinction is thus conceived and experienced as an ongoing process: "We are already well into the sixth mass extinction in Earth's history, and it is being caused by us. The comet isn't coming, it has arrived". ${ }^{15}$

Sodikoff has argued that such concerns mark a significant shift from original extinction narratives, as these emerged in the course of the nineteenth century, when European scientists first came to ponder about the extinction of "primitive" groups or "races" under the bane of "civilization". ${ }^{16}$ And yet one should note that a great number of contemporary extinction narratives retain the paternalistic idiom of what Renato Rosaldo has described as a paradoxical if no less productive form of "imperialist nostalgia", whereupon one first exterminates or irrevocably changes a form of life, only to then mourn and regret "that things have not 
remained as they were prior to the intervention". ${ }^{17}$ Moreover, Victorian interests in extinction did not solely revolve around dying or lost "tribes". As a principle of natural selection articulated by Charles Darwin and made visible in popular publications and exhibitions of fossils, by the second half of the nineteenth century the idea of extinction both fascinated Western publics and threatened their view of humanity. ${ }^{18}$ Janet Chernela has provocatively argued that it is worth considering the extent to which it was not so much the idea of "common origins" elaborated by Darwin's The Origin of Species as the specter of a "common ending" between human and nonhuman animals (lying outside the book itself) that posed the biggest challenge to Western visions of humanity's destiny. ${ }^{19}$ In Chernela's view, the fact that humans did not feature in The Origin of Species, or were even deliberately omitted from it, "underscored the importance of the missing message". 20 Insofar as humankind was included within the gradual process of given species slowly becoming more and more rare until they finally die out, the notion of extinction as a common, pan-species destiny challenged both redemptive visions of humanity's "exceptional" future (be these religious or secular) and progressivist ideologies where the nonending process of development was configured as an end in itself. Neither ending up in some redemptive millennium or in the realization of species-being in a socialist utopia nor, however, nonending in the guise of perpetual "progress", humanity was for the first time included in a possibility of a final, meaningless end - an end that would, by grace of its cross-species commonality, reduce or return us to our animal origins, as configured by the epistemic framework of natural selection.

Perhaps no popular work reflected the impact of this new vision of beinghuman more acutely than the writings of H. G. Wells, whose The Extinction of Man opened by attributing humankind's incredulity to the possibility of its own demise to "excessive egotism": "“A world without us!', it says, as a heady young Cephalapsis might have said it in the old Silurian sea". ${ }^{21}$ Wells' oeuvre provides a kaleidoscopic vision of different routes to human extinction, which can be read as Victorian mythic variants of the end of the world. ${ }^{22}$ Among different tropes, two appear to be prevalent: one concerns the possibility that "man through his own doing would bring about conditions where the laws of nature would determine his extinction"; the other concerns the possibility of humanity becoming extinct in the hands of a more "evolved" terrestrial or extraterrestrial being. ${ }^{23}$ Linked to narratives of "degeneration" (the shadow twin of evolutionism prevalent at the time), both variants related to Wells' key warning that, be it internal or external, "the Coming Beast must certainly be reckoned in any anticipatory calculations regarding the Coming Man". ${ }^{24}$

In contrast to Darwin's idea of extinction and its popular reception at the time, contemporary sixth extinction narratives do not portray the latter as part of an "economy of nature". ${ }^{25}$ Configuring extinction as a fundamentally anthropogenic process, ever since Norman Myers' paper on “disappearing species”, sixth extinctionism has been permeated by a vision of humanity as simultaneously part of and apart from nature. ${ }^{26}$ In her review of Myers' work, Chernela notes that the former colonial officer conceived nature as "the patrimony of mankind". ${ }^{27}$ 


\section{Introduction}

This fueled a vision of decreasing biodiversity as a threat to human development, insofar as the loss of any one species constitutes a loss in "value" for humanity. Besides the obvious "naturalized capitalism" overtones, what is worth underlining is the ontological and biopolitical entanglement of the particular schema. ${ }^{28}$ Rather than simply being a rehearsal of what Ursula Heise has identified as 200 years of "cultural anxiety over vanishing nature", what we see here is the transformation of extinction from a process driven by nature (of which humanity is inalienably a part) to today's configuration of the former as a result of human activity. ${ }^{29}$ This $^{2}$ transformation fosters an ontological exceptionalism that posits humans outside the realm of "decreasing biodiversity" while rendering the latter redeemable only via human intervention. Yet rather than being led to conclude, with Chernela, that this framing excludes humanity from the threat of extinction, we should maintain that, on the contrary, it captures it in an inclusive exclusion whose biopolitical implications need to be taken seriously.

Existential risks, defined by Nick Bostrom as "one[s] where an adverse outcome would either annihilate Earth-originating intelligent life or permanently and drastically curtail its potential", are often said to be the result of the "success of Homo sapiens" over the past couple of centuries. ${ }^{30}$ The Oxford philosopher reasons that since we have so far survived "natural" existential risks as a species, "it is prima facie unlikely that any of them will do us in within the next hundred [years]". ${ }^{31}$ Thus, while meteor impact, volcanic eruption, or black holes do feature in canonical lists of existential risk, what principally concerns human extinction pundits are "self-inflicted" catastrophes. In the typology provided by John Leslie in his acclaimed The End of the World, these are listed as including human aggression (nuclear, chemical, or biological warfare), environmental impact (greenhouse effect, pollution, food/water exhaustion, overpopulation, and, we could add, antimicrobial resistance), and technological advancement (genetic engineering, digital/computer technology, nanotechnology). ${ }^{32}$ The implicit premise of contemporary human extinction narratives is that all these existential risks are interlinked and mutually entangled through the development of human technology, which either generates or facilitates the projected extinction event. This includes both the development and globalization of technologies, like fossil fuel-based industry and transport, and the emergence of new technologies, such as artificial intelligence. The former are usually seen as carrying over a mid- to long-term accumulative impact (e.g., the Anthropocene, global warming), while the latter as threatening to usher in rapid, uncontrollable change by "error" or by "terror"; that is, either accidentally or as the result of human malice (e.g., bioterrorism or an EMP attack). ${ }^{33}$ Without going into further detail, for the purposes of this Introduction, we need to take a quick look into the ideological heart of this narrative. Underscoring the various technoscientific visions of the end of humanity is the premise that technological development is in itself an inalienable part of being-human. Indeed, a key vernacular anthropological narrative of modern Western societies revolves around the mythic image of becoming-human not so much by grace of developing language, ritual, or symbolic thought but primarily by inventing the first technological tools. The genealogy of this Promethean 
transformation of technology from a means to various goals into the telos and, at the same time, essence of humanity cannot be drawn here. What is important is to keep in mind that, through this framing of anthropogenesis, technological development is naturalized as humanity's self-realization - the very heart of human nature, and the pivot of human emergence. Thus unfolds human extinction cloaked in the rags of tragedy: humans cannot help it; we simply have to become more and more technological; it is in our DNA (as a technoscientific rendition of the more traditional "blood") to seek and develop new, more efficient tools that will lead to the expansion of mastery. Seeking thus no more than to realize our true nature (becoming-masterful), we are trapped in a process that unleashes a series of threats to our very existence.

This tragic schema marks an important departure from Victorian understandings of extinction but also from twentieth-century Cold War concerns about human self-destruction. In the case of Victorian visions of human extinction, as we have already seen, the latter was a natural process, which leveled humanity down to its originary, animal nature. In the case of Cold War imaginaries, by contrast, human extinction, literally looming over our heads in the form of the Nuke, was an aberration from humanity - the result of a few "Dr. Strangelove" maniacs in the Pentagon or in the Kremlin gambling human existence for personal power or for an ideological abstraction. In our age and time, by contrast, the responsibility for both the sixth extinction and human extinction (either as part of the former or as an independent event) is diffused, not only in the sense that it is shared by all humans in a horizontal manner but also in that it is internalized as the consequence of what makes us human. Having condemned any attempt to social organization contrary to capitalism as leading inexorably to totalitarianism, and thus to a repression of human nature, this narrative then represents complex material challenges to human existence under the reign of globalized capital (global warming, new epidemiological patterns in infectious and noninfectious diseases, the degradation of the environment, deregulation of subsistence, etc.) as indexes of a coming, all-consuming catastrophe, which is in turn presented as the result not of a historically specific political economy but of human nature.

In this sense, narratives of human extinction tend to be forms of mystification, which reduce concrete and complex historical processes into an anthropological abstraction. Yet more than that, this book would like to argue, they are mythic registers of anthropogenesis: visions of an end that immerse us into an anthropological imaginary - a realm where what is human, what is not human, and what lies between the two is negotiated, forged, and challenged, so as to function as a relatively autonomous sphere of symbolic and performative repertoires of humanity.

\section{The next pandemic}

The focus of this book is on a particular "mythocosmological variant" of human extinction and the way in which it has come to institute visions of humanity and its relation to the nonhuman. ${ }^{34}$ This variant has, in recent years, assumed paramount 


\section{Introduction}

proportions across the sciences and governmental and international policies, as well as in cultural production: the so-called next pandemic.

"It all started with the world getting sick", reflects the narrator of the first episode of the TV adaptation of The Twelve Monkeys. As scenes of queues of ill people give way to mass burials and torching corpses with flamethrowers in the snow, the voice continues: "Humanity is on its way out, one more generation at best. The virus is mutating, evolving". ${ }^{35}$ In terms of variants of human extinction, the next pandemic holds a productively ambiguous position. With the exception of scenarios involving bioterrorism or biological warfare, this is a type of extinction that arises directly from "nature", seen as both the reservoir and plane of immanence of microbial pathogens. Still, we should not be hasty to conclude that this excludes it from the framework of anthropogenic existential risks held by pundits of the field to be the prime threat to human survival - for this projected event is consistently depicted as arising from a range of drivers involving in one way or another the application of human "culture", usually in the form of global technological and economic development.

The idea of a next pandemic as an event threatening humanity with imminent extinction arose in the early 1990s out of a shift in epidemiological reasoning, which ushered in the now prevalent notion of emerging infectious diseases (often summed up as "EID"). Nicholas King has traced the "emergence of "emergence" to the 1989 conference "Emerging Viruses" chaired by Stephen S. Morse, an American epidemiologist who differentiated between evolutionarily new viruses and "existing viruses transferred unchanged or with slight variations to the human population". ${ }^{36}$ King stresses that the rhetorical power of this distinction was derived from the notion that while true evolutionary change cannot be predicted, the aforementioned type of variation and interspecies transfer can. This new epidemiological framework placed particular emphasis on zoonotic diseases: diseases transmitted to human from other animals. As we will examine in Chapter 2, through the prism of emergence, zoonosis was itself transformed from a routinized into a charismatic epistemic thing. Shifting attention away from long-term persistence patterns of diseases among animal populations yet not abandoning the general premises of disease ecology, the paradigm of emergence led to a focus on the so-called spillover - the process through which a pathogen "jumps" the proverbial "species barrier" and begins to circulate within and between human populations for the first time, with catastrophic consequences. Emergence-led epidemiological reasoning thus promoted the vision of an ontological and at the same time biopolitical breach through which human/nonhuman distinctions evaporated in a moment of pathogenic commensality.

Emergence is thus a process considered as prone to expose humankind to an asymmetrical threat of fatal proportions. Being immunologically "virgin" visà-vis emerging pathogens, humans (as a species totality) are pictured as being vulnerable to a devastating kill-off, which would furthermore be facilitated by rapid intercontinental travel, free trade, and liberal democratic civil rights. This has been part of a broader biomedical discourse that presents infection as an existential battle - a struggle defined by microbial intentionality, cunning, and 
deceit. ${ }^{37}$ In his recent ethnographic work on pandemic preparedness, Carlo Caduff has shown how virologists paint a nefarious picture of pathogens like avian flu: a "killer strain lurking in the shadows". ${ }^{38}$ Yet more importantly, Caduff argues, emergence ontologizes viruses-about-to-spillover as "indeterminate entities". 39 These mutant strains are seen as enemies of humankind that necessitate a form of vigilance, which in recent years has featured in government policies and budgets under the name of "pandemic preparedness" - a regime of predictions, modeling practices, data mining, syndromic surveillance, and sentinel watching that has been extensively examined by medical anthropologists. ${ }^{40}$

As a consequence, the next pandemic has become a catalyst of major biopolitical transformation, international intervention, and cycles of investment - processes that have been periodically fueled by regional outbreaks of diseases such as Ebola (2014-2016) or fears of antimicrobial resistance (AMR). At the same time, global interest in the next pandemic has unfolded on the basis of a systematic entanglement between science, policy, and cultural production. King traces the institutionalization of emergence in the report Emerging Infections: Microbial Threats to Health in the United States, authored by a National Academy of Science's Institute of Medicine committee co-chaired by Morse and Joshua Lederberg. ${ }^{41}$ Written in the shadow of the AIDS/HIV pandemic, the report was a landmark in reversing the draining of funds for research in infectious diseases, directly "targeting policymakers and framing its arguments in terms of American public health and national security". ${ }^{42}$ As a result of an aggressive media advocacy program, journalists became quickly interested in the notion of emergence, "a powerful scalar resource for characterizing individual outbreaks as incidents of global significance". ${ }^{43}$ Literary scholar Priscilla Wald has argued that it is crucial to recognize that "the question simmering beneath even the most sedate accounts" of actually existing outbreaks, such as Severe Acute Respiratory Syndrome (SARS) or Ebola, is "whether this disease, with its unknown origins and alarming mortality rate, might be the "coming plague". ${ }^{44}$ This practice of configuring limited, local outbreaks of infectious disease as precursors or indeed "rehearsals" of global pandemics underlines what Wald has coined "the outbreak narrative" - a "paradigmatic story" about disease emergence. ${ }^{45}$

At the helm of these efforts in the early 1990s was Richard Preston's New Yorker article "Crisis in the Hot Zone" (1992), warning against the emergence of a pathogen that "could wipe out our species". ${ }^{46}$ Soon after, the idea of the next pandemic, was rapidly popularized and disseminated through a series of international bestsellers. In her 1994 book The Coming Plague, Laurie Garrett presented the next pandemic as a result of shifting cultural practices, geopolitical relations, and economic regimes, which she described as resulting in a perilous "world out of balance". ${ }^{47}$ Similarly, that same year, Preston in his book The Hot Zone forecasted the next pandemic as a result of ecological damage, theorizing that "[i]n a sense, the earth is mounting an immune response against the human species". ${ }^{48}$ As will be examined in Chapter 4, by the second decade of the new millennium, the entanglement between science, policy, and cultural production had become so thoroughly institutionalized that the US Centers for Disease Control 
and Prevention (CDC) trained Hollywood actors for Steven Sodenbergh's blockbuster Contagion (2011) and even launched a preparedness campaign featuring zombies as the agents of the next pandemic. ${ }^{49}$

Though not an anthropologist, Wald has noted the mythic character of "the outbreak narrative", which she largely sees as maintaining "imagined communities" via the articulation of sociocultural norms "as enduring truths". ${ }^{50}$ More recently, Frédéric Keck has advanced a less functionalist reading of the mythic aspect of pandemics in his examination of avian influenza. Keck follows Claude Lévi-Strauss' analysis of mad cow disease so as to argue for a more sustained attention to the role of zoonosis-related origin myths in the reclassification of animals and human/nonhuman relations. ${ }^{51}$ This analysis of zoonotic diseases and their pandemic potential has underlined that a mythic reading of animals as the source of human extinction allows us to see how human/nonhuman relations assume a pivotal role in the problematization of human existence. At the same time, Keck shows how the "eventalization" of the next pandemic revolves around myth becoming reality (or indeed ritual) through the application of preparedness technologies. ${ }^{52}$ In this way, the outbreak narrative may be said to operate not only in analogy to epidemiological maps or the microscope, as a means of making visible what is already in place, but also, most importantly, as Carlo Caduff has proposed as a prophetic apparatus: a way of visualizing an ever-elusive yet imminent future. ${ }^{53}$

It is, of course, true that plagues and pestilences have formed part of prophetic traditions going back to Greek drama and the Bible (think Sophocles' Oedipus Rex or the plague of Ashdod in 1 Samuel 5:6). It is also true that such traditions were revived at the dawn of the nineteenth century as part of broader sociocultural and political transformations in the Western hemisphere. However, in contrast to Mary Shelley's sibylline vision of a (noncontagious) pestilential apocalypse in The Last Man, the prophetic faculty of the "coming plague" bears no Romantic undertones. ${ }^{54}$ Indeed, as will be discussed in more detail in Chapter 1, the next pandemic sits uncomfortably within the framework of apocalyptic events. Recent works on the "end of the world", both in and outside anthropology, have engaged systematically with the question of the apocalyptic in secular "ends", like the one brought about by climate change. ${ }^{55}$ In light of this discussion, it would seem that pandemic-borne human extinction carries with it an apocalyptic potential insofar as it supposedly reveals essential truths about the human condition. However, as will be discussed in detail in Chapter 1, if the apocalypse in its many religious or secular forms entails a temporality punctuated by the mutual, anti-dialectical immanence of a finite end (the "end of time") and an absolute, that is to say extratemporal, beginning, the next pandemic is instead underscored by what Elana Gomel has described as "an accumulation of repetitive episodes, deferring any kind of meaningful closure". ${ }^{56}$ In other words, if humanity's apocalyptic being-inthe-world is always already a being for an eschaton, by contrast, human existence under the sign of the next pandemic unfolds in accordance to "a cyclical plot" of meaningless endlessness, which strips humanity's end of any redemptive quality while abandoning human existence to the realm of a monotonous repetition of 
extinction deferrals. ${ }^{57}$ The anticipation of the next pandemic thus operates according to what, echoing the great Italian poet Cesare Pavese, we may call the tired poetics of deferral. ${ }^{58}$ Far from being an active poetics of death and resurrection, this gospel is empty of hope or redemption - a vision populated by omens and signs of an "end indefinitely postponed" instead. ${ }^{59}$ In this sense, the vision of the next pandemic may be said to be prophetic, only insofar as the prophecy in place does not point to a redemptive end but rather to an end without ending: not simply a protracted twilight of humankind but a humankind hollowed of its humanity. ${ }^{60}$

Whereas other "end of the world" variants, like nuclear holocaust or meteor impact, denote the annihilation of human (or indeed planetary) life as such, in the case of the next pandemic not only does life on Earth continue, but in fact proliferates; it takes over the planet and engulfs humanity (see Chapter 5). And yet it would be hasty to say that, in the terminology recently developed by Danowski and Viveiros de Castro, the next pandemic is imagined as leading to a "world without us" rather than to "us without the world". ${ }^{61}$ For, in fact, at the mythic heart of the next pandemic lies no less than a biopolitical and at the same time ontological reversal. The pandemic is imagined as striking not simply human populations - or even the human species as a whole - but rather at the heart of humanity as a project for mastery. I am following here Walter Benjamin who, in a characteristic anthropological materialist turn, noted that our modern predicament is not so much underlined, as Theodor Adorno and Max Horkheimer believed, by the mastery of nature (Naturbeherrschung) but instead by the "mastery of the relation between nature and humankind". ${ }^{62}$ Giorgio Agamben is right to note that the key to this formula is "only the 'between', the interval, or, we might say, the play between the two terms, their immediate constellation in a non-coincidence". ${ }^{63}$ Thus, for human mastery over human/nonhuman relations to be the operative field of the project called humanity, it requires not so much a subject-object relation as a dynamic field of difference, where the relation between relations, to remember Lévi-Strauss, assumes the role of a structure for human existence. This "between" forming the locus of exercise of human mastery is no less than the locus of articulation between being, becoming, and remaining human.

The central theme of Human Extinction and the Pandemic Imaginary revolves precisely around this observation: what is at risk in pandemic scenarios of human extinction developed in the global West is not simply, or primarily, human biological survival, but instead the survival of humankind as human - the survival of humanity. Thus, a series of questions is raised: How is the human condition (qua humankind's humanity) configured through the anticipation of human extinction? How does a vision of what it means to be human emerge from the imminent yet always already deferred end of humanity? What forms of being-human does this pandemic vision establish as worthy of defense or sacrifice? Which traits of humanity and its relation to the world does it configure as inalienable, and which ones as worth giving up so as to remain human? To what extent and in which ways is human extinction configured as a process of self-extinction? And how does this, ultimately, redefine humanity's relation to itself as both an ontological constant and as a process of realization? 


\section{The pandemic imaginary}

In order to propel these questions into an anthropological examination of human extinction, this book proceeds by investigating what I would like to call the "pandemic imaginary". This does not refer to an imaginary pandemic or to historical ideas about the pathogenic qualities of the imagination, such as were once prevalent in Europe. ${ }^{64}$ Nor, however, should the proposed notion of the pandemic imaginary be read within the enduring analytical indistinction between the imagined and the imaginary, or the imaginary and imagination, which, as Claudia Strauss has noted, ends up with using the term as a synonym for culture. ${ }^{65}$ Instead, the term here is intended to relate to the imaginary as an instituting force of the social, in dialogue with the work of Cornelius Castoriadis.

In his Imaginary Institution of Society, Castoriadis famously distanced himself from psychoanalytic notions of the imaginaire. Opposed to a view of the "specular", as "a by-product of Platonic ontology" (the eidolon), Castoriadis proposed an analytic that saw the imaginary not as a reflective surface of reality but as a creative principle. ${ }^{66}$ Rather than consisting in "images of", for Castoriadis the imaginary "is the unceasing and essentially undetermined (social-historical and psychical) creation of figures/forms/images, on the basis of which alone there can ever be a question of 'something". ${ }^{67}$ This rejection of Lacanian metaphysics (and structuralism as a whole) led to an understanding of the imaginary as something that, on the one hand, needs to "pass through the symbolic in order to be expressed" and, on the other hand, is not subsumed to it but exceeds it insofar as the symbolic "cannot [. . . ] without the capacity to "see in a thing what it is not, to see it other than it is" .68

If, as Arnaud Tomes notes, for Castoriadis the imaginary never assumes the status of a "hyperconscience" or of the collective unconscious, what is then its role in human societies? ${ }^{69}$ As he often reflected, Castoriadis himself was confronted with the question: "Whose imagination is this? Show us the individuals who ... or the factors that . . and so on".$^{70}$ The problem with this question is that it relies on an understanding of the imaginary that is not compatible with the one developed by Castoriadis and adopted by this study - for it reduces the imaginary into a subject-object process of "representing the images of reality, or images that combine elements taken from the real" ${ }^{71}$ The way this study, following Castoriadis, understands and explores the imaginary, by contrast, is not as a process of producing images or as the "reproduction of what already is" but as the "emergence of what is not": a defining faculty of being-human in the sense that it is the "continuous origin" of society. ${ }^{72}$

This understanding of the imaginary is central to Castoriadis' opposition to ontologies of determinacy - which, in simple terms, postulate that " $t o$ be is to be determined" ${ }^{73}$ In this sense, his notion of the imaginary seems to share with Jean-Paul Sartre's take on the imagination the crucial aspect that, as a capacity for seeing and acting on the world "as different from what [is]", it forms not simply a "power of consciousness" but is rather "the whole of consciousness as it realizes its freedom". ${ }^{74}$ As Nigel Rapport has argued, what defines 
imagination for Sartre is "the ability of the human mind to imagine what is not the case". ${ }^{75}$ However, crucial differences exist between Sartre's and Castoriadis' approach of the imaginary. For Castoriadis the imaginary is a primary function of human societies, in the sense that these derive and are formed by humankind's imaginary capacity. This is the instituting capacity of the imaginary. Yet, for Castoriadis, the imaginary is both what allows the (inter)institution of social and individual autonomy (or "freedom" in Sartre's terms) and what lies at the heart of individual and social heteronomy. ${ }^{76}$ The systematic examination of these two aspects of the imaginary (one instituting, the other instituted) allows us to avoid collapsing Castoriadis' political ontology into existentialist metaphysics of freedom.

On the one hand, for Castoriadis the imaginary is instituting in the sense that it is a creative force: in particular, a force responsible for "bringing into being a form that was not there before, the creation of new forms of being". ${ }^{77}$ Castoriadis explains, "It is ontological creation: of forms such as language, institution qua institution, music, and painting; or of some specific form, some work of art, be it musical, pictorial, poetic, or other" ${ }^{78}$ The instituting imaginary must thus be seen as a "vis formandi", which is immanent both on a social and on an individual level. ${ }^{79}$ For Castoriadis, "It is the instituting social imaginary that creates institution in general (the institution as form) as well as the particular institutions of each specific society, and the radical imagination of the singular human being". 80

This study shares with Castoriadis the premise that the instituting imaginary is not simply one more social faculty but the very principle of society as a process of self-creation or autopoiesis. It is in this sense that the instituting imaginary is "radical" or "creative" rather than simply "productive" a society not simply to change but to self-institute itself according to the establishment of new forms of social and individual being and thus to reach for what Castoriadis calls "autonomy". 82

However, if the imaginary is the capacity that generates new kinds of social and individual being, in Castoriadis' political philosophy, it is also what guarantees social reproduction. Once "crystallized" and "solidified" in given institutions, it takes the form of an instituted imaginary: "It assures continuity within society, the reproduction and repetition of the same forms, which henceforth regulate people's lives", until they are themselves replaced by either gradual historical change or radically new forms deriving from the instituting imaginary. ${ }^{83}$ However, this instituted imaginary, which operates through "socially sanctioned symbolic systems", is not simply a byword for hegemony or ideology. ${ }^{84}$ Instead, it forms the very basis for society's autopoetic faculty insofar as reflecting critically upon it is foundational to a society "recogniz[ing] in its institution its own self-creation" and thus

institut[ing] itself explicitly and overcom[ing] the self-perpetuation of what is instituted by showing itself to be capable of taking a new look at it and 
transforming it in accordance with its own requirements and not following the inertia of the already-instituted, of recognizing itself as the source of its own otherness. ${ }^{85}$

This approach then sets my reading of the pandemic imaginary apart from both discussions of technoscientific or sociotechnical imaginaries/imagination and Charles Taylor's reduction of the "social imaginary" into "that common understanding that makes possible common practices and a widely shared sense of legitimacy" - both a "'self-understanding' of a society, but also as 'repertory" of the practices which can be adopted by society's members". ${ }^{86}$ At the same time, following Castoriadis' anthropological thought coherently and systematically obviates an important limitation present in the otherwise fruitful attempt by David Sneath, Martin Holbraad, and Morten Axel Pedersen to adopt his ontology of the imaginary. ${ }^{87}$ Set against "the way in which the concept [. . .] is used by anthropologists as a mainly rhetorical device in well-rehearsed constructivist arguments", the three anthropologists have attempted "a positive programme for an alternative anthropology of the imagination". In this they follow Castoriadis in identifying three key fallacies in social scientific approaches of the imagination: its reduction into a by-word for "culture", its understanding through its function or functions in specific social settings, and its admiration as a source of inspiration or creativity. ${ }^{88}$ As Castoriadis pointed out in his Imaginary Institution of Society, the way in which the imaginary has been traditionally conceived is such that "it is never thought for itself: it always rests in the service of something else". ${ }^{89}$ To remedy this, Sneath, Holbraad, and Pedersen have proposed a processual view informed by Kant's approach of the imagination as a pervasive faculty of human consciousness, Tim Ingold's anthropology of technology and its social role, and Castoriadis' idea of the "indeterminate' character of the imagination". 90 "The key idea here", they write, "is that the imagination can be defined in terms of its irreducibly indeterminate relationship to the processes that precipitate it (i.e. its 'technologies')". ${ }^{91}$ Following Castoriadis in arguing that "a broad but analytically precise distinction can be made between phenomena whose emergence is fully conditioned and phenomena whose emergence is not fully conditioned", Sneath, Holbraad, and Pedersen conclude that

only the latter are to be conceived as phenomena of the "imagination". The place of the imagination, then, is the place of indeterminacy in social and cultural life, and it can be empirically identified and ethnographically explored with reference to the processes or technologies that open it up..$^{92}$

Whereas this turn has been successful in producing nuanced ethnographies and in renewing anthropological interest in the study of the imaginary, it fails to account for its dynamic role as both a creative and a conserving faculty. ${ }^{93}$

Human Extinction and the Pandemic Imaginary argues that, in contemporary technoscientific societies, the pandemic imaginary plays an irreducibly dynamic role. On the one hand, it can enable us to conceptualize a future where human 
mastery over human/nonhuman relations has ceased to be humanity's condition or destiny. It is, in other words, an imaginary that is potentially institutive of human futures without human mastery and, at the same time, of a present awakening insofar as, to use Adorno's turn of phrase, "the absurd is presented as self-evident in order to strip the self-evident of its power" ${ }^{94}$ Yet, at the same time, the pandemic imaginary is also a set of instituted ideas insofar as it forms part of the biopolitical apparatus of preparedness. As such, it hampers the conceptualization of the future in terms of a radically new potentiality; in other words, in terms of an alternate anthropogenesis and of a new reality principle (see Chapter 5). Hence, while pandemic-borne human extinction forms an imaginary that holds the potential of radical indeterminacy, allowing us to see the human condition as other than is (a future without human mastery), within its specific historical conditions it generates a vision of what following Danowski and Viveiros de Castro we can call a "future-that-is-over", or to be more precise, the future either as what already is or as nothing. ${ }^{95}$ This is a vision of humanity having finally arrived at its proper plane of existence, which can either be maintained or lost but in no way overcome an anthropogenic telos; humanity as Being-in-itself.

This anthropological study aims to explore the tension between what we may call the two operative poles of the pandemic imaginary, its instituting autonomy and its instituted heteronomy faculty, and the consequences of their interplay as regards the way in which the human condition is instituted today. ${ }^{96}$ This does not, however, mean that the two positions or poles of this political ontological process should be treated in a symmetrical manner. Following Castoriadis' anthropological thinking, this study assumes as its political-philosophical framework the premise that if autonomy, based on the unceasing reflexion upon social organization and the critique of institutions and representations structuring one's society and culture, is the condition of realizing humanity as a process of self-institution through alterity (becoming other that what is), then heteronomy comprises, by contrast, the historically sedimented tendency of humanity toward what Castoriadis following Thucydides called "quietness" - a drive "towards inertia, towards irresponsibility, and towards the acceptance of authority". ${ }^{97}$ In these terms, the interplay between the autonomy and the heteronomy faculty of the pandemic imaginary (or any social imaginary for that matter) is a tension that is structurally unequal. For the former relates to humankind's ability to be "for itself"- in other words, its potentiality for autonomy whereas the latter relates to humankind's propensity to be "in itself" - in other words, its proneness for voluntary servitude. Rather than simply being a heuristic or agitating device, this position forms the anthropological backbone of this book, as a study that, following the critical-theoretical tradition, aspires to illuminate human extinction and the next pandemic as thresholds in the imaginary institution of society.

\section{Between science, policy, and cultural production}

Human Extinction and the Pandemic Imaginary explores the ways in which "the transformative force of myth [and] the authority of science" is fused into 
a pandemic imaginary in the intersection between science, policy, and cultural production..$^{98} \mathrm{My}$ aim is to examine how the anticipation of human extinction brought about by the next pandemic functions as the pivot of an anthropological transformation, a critical shift in the way we conceive humanity brought about by an unsettlement in the vision of human mastery over human/nonhuman relations.

For an anthropologist who works on epidemics and epidemiology on the basis of ethnographic and archival research, undertaking the task of approaching a phenomenon that cannot be empirically grasped by the analytical planes of "experience" and "practice" - and indeed supersedes them - poses a particular challenge. To this purpose, the book relies on a tradition that anthropologists have fruitfully utilized in their own explorations of what lies beyond the ethnographic or archival continuum: critical theory, and in particular Walter Benjamin's anthropological materialism. This is all the more pertinent as the object of my investigation and critique is the way in which the mythic and the scientific are entwined and crossgerminated in the pandemic imaginary. ${ }^{99}$

As Susan Buck-Morss has argued, the identification of mythic "elements with the most modern phenomena" in Benjamin's work was aimed at illuminating (rather than "resolving" in the Hegelian sense) the contradictory character of modernity. ${ }^{100}$ As such, it was a method aimed not at revealing some self-contained reality but at awakening us into (not from) the dream that structures modern life. Central to this project was the employment of a "microscopic gaze" (a phrase Theodor Adorno used for Benjamin): "a means for making the very particularity of the object release a significance which dissolved its reified appearance and revealed it to be more than a mere tautology, more than simply identical to itself'. ${ }^{101}$ Retaining the particularity of minute and fragmentary social and cultural phenomena under examination while at the same time going beyond their "given" immediacy, this approach presumes that "nonidentity [is] the locus of truth". ${ }^{102}$ It thus allows us to forge new, illuminating, and at the same time necessary relations between the salvaged fragments of our investigation. ${ }^{103}$ This method then authorizes not only the recognition of usually overlooked or devalued components of social and cultural life, lying as they do in our case in the growing zone of indistinction between science, policy, and cultural production, but also the radical transformation of their value insofar as it fosters an anti-contemplative, anti-panoramic, and as a result anti-reifying approach where the anthropologist assumes the guise of the "ragpicker"; a Benjaminean figure that by contrast to its more illustrious cousin, the flâneur (a romantic, even rhapsodic character), is at one and the same time "methodic, reflexive and implacable", in that his or her systematic trajectory involves an "attentive[ness] to the new, without succumbing to madness". 104 Human Extinction and the Pandemic Imaginary is then an anthropological investigation that, by proceeding attentively through the fissures of contemporary visions of the end of humanity, as these are rehearsed in the crossroads between scientific, policy, and popular culture significations and practices, aspires to move beyond the "Hippocratic face" of history and "to acquire the density of experience without losing any of its rigour". ${ }^{105}$ 
Central to this study are visual images, which, to paraphrase Frédéric Keck, we may claim form "the basis for a perception of a still invisible catastrophe". ${ }^{106}$ Ranging from films and photographs to diagrams and scientific illustrations, these are productively positioned between science and fiction and thus form a paradigmatic field for the emergence and consolidation of the pandemic imaginary. This study does not mount a theory of images or figuration (as an operation of making visible what is invisible), as recently being developed by anthropologists like Philippe Descola or Carlo Severi. ${ }^{107}$ And yet it shares with them, as an analytical baseline, the idea that "the image has its own mode of action insofar as it captures the intersecting intentions of their maker and the person who looks at it". ${ }^{108}$ In the case of the pandemic imaginary, images operate within processes of figuration that, on the one hand, allow capacious exchanges between scientific, lay, and fictional framings of the next pandemic and human extinction, while, on the other hand, retain a transformative potential as regards, more broadly, understandings of infectious diseases and existential risk. ${ }^{109}$

\section{The book's structure}

Human Extinction and the Pandemic Imaginary begins by critically examining the popular idea that the next pandemic is part of a broader apocalyptic imaginary in Western societies. In dialogue with anthropological and philosophical works on catastrophe, eschatology, and the apocalypse, Chapter 1 explores how human extinction under the bane of the next pandemic challenges this apocalyptic reasoning. Arguing that the apocalyptic potential (or lack thereof) of the next pandemic needs to be examined through an exploration of the relation between the end of time and the time of the end, I take up Danowski and Viveiros de Castro's invitation for an anthropological engagement with the Paulian notion of the katechon. Chapter 1 thus juxtaposes the temporality of the next pandemic to the one of the apocalypse, pointing out that between the two there is a relation of mythic reversal. This reversal, it is argued, entails the replacement of a finite end of the world (in the guise of an apocalypse, with or without a follow-up "kingdom") by the infinite or endless "end" of generalized anomy. Whereas in other visions of the end of the world, such as nuclear catastrophe, anomy has the role of an intermediary state or threshold with which humanity can meaningfully interact by means of prevention or delay (katechon), in the pandemic end of the world it takes the place of the interminable outcome of the next pandemic. Chapter 1 discusses how, understood as a collapse of mastery, this retemporalization of anomy is supposed to be brought about not by means of an erasure of human nature but through its activation, where socially instituting rules and customs, and ultimately mastery as humankind's species-being are abandoned in the name of biological survival.

Chapter 2 focuses on the supposed origin of pandemic-borne human extinction: disease-carrying animals. Focusing on shifting visualization practices, it explores how the loss of mastery over human/nonhuman relations is predicated upon an epistemological transformation in the understanding of zoonosis, or animal-derived infection, as the source of human illness. Conventionally dated at around 1990 but 
still ongoing, this entails an abandonment of hitherto dominant frameworks of zoonosis, which took diseases like plague to be naturally residing in nonhuman animals and only able to infect humans due to a lack of proper (that is to say, modern) habits and structures of interspecies separation. This sanitary-utopian paradigm, which promised the eventual isolation of such diseases in the nonhuman realm, has become dislocated by what is known as the emergence paradigm in infectious diseases. Chapter 2 argues that this has been a model of infection that configures human existence as irreducibly entangled with nonhuman animals; a mode of being that excludes any possibility of sanitary separation and institutes practices of anticipation of emergence that should be considered beyond conventional frameworks of apocalyptic thinking and within medical traditions of prophecy.

If the end of humanity originates in animals, what is then the agent of its spread among humans? Critically examining notions of contagion, Chapter 3 takes as its subject a figure seen since the SARS pandemic of 2003 as pivotal in the universal spread of the killer virus: the so-called superspreader. An individual who, according to current epidemiological narratives, is able to transmit pathogens to an extraordinary number of contacts, the superspreader is examined as a key component in a neoliberal biopolitical doctrine that diverts attention and funding from political economic, infrastructural, and materially complex epidemic etiologies to exceptional individuals. More than this, however, Chapter 3 will show that the superspreader is also a mythic character that brings humanity back into a prehuman condition. Central to this argument is the challenge of the presumption that humanity deprived of mastery relapses into a condition of "total animality" ${ }^{110}$ Instead, a much more radical fall is entailed in the ontological collapse of humanity under the bane of the next pandemic. This microbiological catastrophe brings humanity "back" to a zombie-like state of humankind before techne, as described in that landmark of Western anthropogenesis, Aeschylus' Prometheus Bound. In this sense, the superspreader is shown to be much more than just a heuristic tool of epidemiological reasoning. Instead, it is a character that fills the role of an anti-Prometheus who brings about a reverse anthropogenesis by means of the late-capitalist fantasy of "becoming viral" being finally fulfilled in the most literal and universal way.

The examination of the mythocosmological consequences of pandemic-borne human extinction proceeds in Chapter 4 through the study of a figure set at the antipodes of the superspreader, a character that is depicted as humanity's last chance in the struggle against pandemic collapse: the epidemiologist. By following the transformation of the latter into a culture hero in a series of pandemic films, but also in the pandemic preparedness campaigns of the US Centers for Disease Control and Prevention (CDC), the chapter explores the ways in which human nature and mastery are reconfigured by this process of fictional salvation from the next pandemic. Bringing in dialogue anthropological works on immunology with Grégoire Chamayou's dialectics of cynegetic and pastoral technologies of power, the question is raised: What in humanity itself and in its relation to the world is rendered sacrificeable in the name of the continuation of human mastery over human/nonhuman relations? 
Chapter 5 examines the anthropologically rich terrain of the post-pandemic condition. It is here that the heteronomy faculty of the pandemic imaginary becomes more pronounced. This chapter examines the way in which the post-pandemic condition differs from post-apocalyptic and, in particular, post-nuclear futures. To achieve this, it excavates a pervasive trope of the post-pandemic condition: the idea that following the success of the next pandemic, the world becomes speedily "naturalized" through a process of frenetic rewilding, whereas those humans who have survived remain decidedly "unwild". Post-pandemic humans themselves are seen as unable to reemerge and develop a new way of being-human or to develop any new meaningful relation with the world. Rather than simply falling into the ontological gap between nature and culture, humankind is thus seen as deprived of its foundational, autopoetic capacity, insofar as it is unable to self-create itself anew through its relation to the world following the latter's end as a world to which humans relate through a project for mastery.

The Conclusion of the book launches a critique of the reduction of the pandemic imaginary to yet another form of "capitalist realism". This necessitates reconsidering Michaël Fœssel's and Jean-Luc Nancy's focus on the relation between catastrophism and loss under the light of the pandemic imaginary. Developing an approach that considers the instituted aspect of the imaginary in tension with, but not in opposition to, its instituting aspect, the book's Conclusion argues that the pandemic imaginary should be considered not simply as a form of anthropological closure but as a field of signification that is always already part of the creation of new kinds of institutions and ways of instituting humanity.

\section{Notes}

1 Robinson Meyer, "Human Extinction Isn't That Unlikely," The Atlantic, April 29, 2016, accessed June 10, 2016 www.theatlantic.com/technology/archive/2016/04/ahuman-extinction-isnt-that-unlikely/480444/

2 For a critique of the two centers, see: Rosi Braidotti, "Posthuman Critical Theory," In Critical Posthumanism and Planetary Futures, eds. D. Banerji and M. R. Paranjape, pp. 13-31 (New Delhi: Springer India, 2016).

3 Key texts, in terms of their cross-disciplinary range, include: Roy Brassier, Nihil Unbound: Enlightenment and Extinction (New York: Palgrave Macmillan, 2007); Evan Calder Williams, Combined and Uneven Apocalypse (Hants: Zero Books, 2011); Déborah Danowski and Eduardo Viveiros de Castro, The Ends of the World, translated by Rodrigo Nunes (Cambridge: Polity Press, 2016); Jean-Pierre Dupuy, Pour un catastrophisme éclairé. Quand l'impossible est certain (Paris: Seuil, 2004); Michaël Fœssel, Après la fin du monde, Critique de la raison apocalyptique (Paris: Seuil, 2012); Donna Haraway, Staying with the Trouble: Making Kin in the Chthulucene (Durham, NC: Duke University Press, 2016); Timothy Morton, Hyperobjects: Philosophy and Ecology after the End of the World (Minneapolis, MN: University of Minnesota Press, 2013); Jean-Luc Nancy, After Fukushima: The Equivalence of Catastrophes, translated by Charlotte Mandell (New York: Fordham University Press, 2014); Isabelle Stengers, In Catastrophic Times: Resisting the Coming Barbarism, translated by Andrew Goffey (London: Open Humanities Press, 2015); Anna Lowenhaupt Tsing, The Mushroom at the End of the World: On the Possibility of Life in Capitalist Ruins (Princeton: Princeton University Press, 2015). 
4 In particular: Günther Anders, Le temps de la fin (Paris: L'Herne, 2007); Günther Anders, Hiroshima est partout (Paris: Seuil, 2008); Hans Jonas, The Imperative of Responsibility: In Search of an Ethics for the Technological Age (Chicago: The University of Chicago Press, 1985).

5 Danowski and Viveiros de Castro, The Ends of the World, 20.

6 Danowski and Viveiros de Castro, The Ends of the World, 20.

7 Alok Jha, "A Deadly Disease Could Travel at Jet Speed Around the World: How Do We Stop It in Time?," The Guardian, November 12, 2013, accessed April 10, 2016 www. theguardian.com/science/2013/nov/12/deadly-disease-modern-global-epidemic

8 Neil Gerlach and Sheryl N. Hamilton, "Trafficking in the Zombie: The CDC Zombie Apocalypse Campaign, Diseaseability and Pandemic Culture," Refractory: A Journal of Entertainment Media 23 (2014) https://refractory-journal.com/cdc-zombie-apocalypsegerlach-hamilton/

9 I am here paraphrasing: Michaël Fœssel, "La 'fin du monde': une métaphore pour le présent?," Esprit 388(10) (October 2012): 35, my translation.

10 Genese Marie Sodikoff, "Introduction: Accumulating Absence: Cultural Products of the Sixth Extinction," In The Anthropology of Extinction: Essays on Culture and Species Death, ed. Genese Marie Sodikoff, pp. 1-16 (Bloomington and Indianapolis: Indiana University Press, 2012).

11 Norman Myers, The Sinking Ark: A New Look at the Problem of Disappearing Species (Oxford: Pergamon Press, 1979); Richard Leakey and Robert Lewin, The Sixth Extinction: Patterns of Life and the Future of Humankind (New York: Anchor Books, 1995).

12 Some examples include: Elizabeth Kolbert, The Sixth Extinction: An Unnatural History (New York: Henry Holt and Company, 2014); James Rollins, The 6th Extinction: A SIGMA Force Novel (New York: William Morrow \& Company, 2014); Chris Carter and Kim Manners, X Files, "The Sixth Extinction," Season 7, Episode 1 (7 November 1999). This study concurs with scholars of science fiction like Peter Y. Paik (2010) that SF films, and more broadly comic books, video games, and other such staple of contemporary cultural production are foundational of social and political transformations.

13 Sodikoff, "Introduction," 2, 4, emphasis in the original.

14 Deborah Rose, Tom Van Dooren and Matthew Chrulew, "Telling Extinction Stories," In Extinction Studies: Stories of Time, Death, and Generations, eds. Deborah Rose, Tom Van Dooren and Matthew Chrulew, p. 1 (New York: Columbia University Press, 2017).

15 Francis Gooding, "Feathered, Furred or Coloured," The London Review of Books 40(4) (22 February 2018): 16.

16 Sodikoff, "Introduction"; Patrick Brantlinger, Dark Vanishings: Discourse on the Extinction of Primitive Races, 1800-1930 (Ithaca, NY: Cornell University Press, 2003).

17 Renato Rosaldo, Culture and Truth: The Remaking of Social Analysis (Boston, MA: Beacon Press, 1993), 72. For discussion, see: Sodikoff, "Introduction," 5-6.

18 On the relation between late-twentieth-century "dinomania" and emerging ideas of "irrevserible extinction" as a result of the rise of ecological consciousness, see: William J. T. Mitchell, The Last Dinosaur Book: The Life and Times of a Cultural Icon (Chicago: The University of Chicago Press, 1998), 19.

19 Janet Chernela, "A Species Apart: Ideology, Science and the End of Life," In The Anthropology of Extinction: Essays on Culture and Species Death, ed. Genese Marie Sodikoff, pp. 18-38 (Bloomington and Indianapolis: Indiana University Press, 2012), 22.

20 Chernela, "A Species Apart: Ideology, Science and the End of Life," 23.

21 Herbert G. Wells, "The Extinction of Man," 1894, accessed August 10, 2016 www. online-literature.com/wellshg/certain-personal-matters/24/ 
22 Robert M. Philmus and David Y. Hughes, "Precarious Man," In H. G. Wells: Early Writings in Science and Science Fiction, eds. Robert M. Philmus and David Y. Hughes, pp. 148-152 (Berkeley, CA: University of California Press, 1975).

23 Philmus and Hughes, "Precarious Man," 148.

24 Herbert G. Wells, "Zoological Retrogression," 1891, accessed August 10, 2016 https:// en.wikisource.org/wiki/Zoological_Retrogression

25 Charles Darwin, On the Origins of Species by Means of Natural Selection, or, the Preservation of Favoured Races in the Struggle for Life (Madison Park: Pacific Publishing Studio, 2010 [1859]), 26.

26 This nature-culture divide, inherent to what following Philippe Descola (2013) we may call the naturalist ontology of extinction, will be explored in Chapter 2; Norman Myers, "An Expanded Approach to the Problem of Disappearing Species," Science N.S. 193(4229) (1976): 198-202.

27 Myers in Charnela, “A Species Apart," 30.

28 For a more recent example of this naturalization, see: Edward O. Wilson, The Future of Life (New York: Knopf, 2002).

29 Ursula K. Heise, Imagining Extinction: The Cultural Meanings of Endangered Species (Chicago: The University of Chicago Press, 2016), 19.

30 Nick Bostrom, "Existential Risks: Analyzing Human Extinction Scenarios and Related Hazards," Journal of Evolution and Technology 9 (March 2002) www.jetpress. org/volume9/risks.html; Fred Guterl, The Fate of the Species: Why the Human Race May Cause Its Own Extinction and How We Can Stop It (New York and London: Bloomsbury, 2012), 3.

31 Nick Bostrom, "Existential Risk Prevention as Global Priority," Global Policy 4(1) (February 2013): 15-31.

32 John Leslie, The End of the World: The Science and Ethics of Human Extinction (London and New York: Routledge, 1996). Similar typologies appear in the growing literature on existential risk, fostered by Oxford's Future of Humanity Institute and Cambridge's Centre for the Study of Existential Risk.

33 The error-terror pun in this context was adopted by Martin Rees in an interview on existential risk: Andrew Martin, "The Scientific A-Team Saving the World from Killer Viruses, Rogue AI and the Paperclip Apocalypse," The Guardian, August 30, 2014, accessed September 10, 2014 www.theguardian.com/technology/2014/aug/30/ saviours-universe-four-unlikely-men-save-world

34 Danowski and Viveiros de Castro, The Ends of the World, 63.

35 Terry Matalas and Travis Fickett, The Twelve Monkeys, "Splinter," Season 1, Episode 1(16 January 2015).

36 Nicholas B. King, "The Scale Politics of Emerging Diseases," Osiris 19 (2004): 65.

37 Emily Martin, Flexible Bodies: Tracking Immunity in American Culture from the Days of Polio to the Age of AIDS (Boston, MA: Beacon Press, 1994); A. David Napier, The Age of Immunology: Conceiving a Future in an Alienating World (Chicago: The University of Chicago Press, 2002).

38 Carlo Caduff, "Pandemic Prophecy, or How to Have Faith in Reason," Current Anthropology 55(3) (June 2014): 297.

39 Caduff, "Pandemic Prophecy, or How to Have Faith in Reason," 300.

40 Carlo Caduff, The Pandemic Perhaps: Dramatic Events in a Public Culture of Danger (Berkeley, CA: The University of California Press, 2015); Frédéric Keck, Un monde grippé (Paris: Flammarion, 2010); Andrew Lakoff, "The Generic Biothreat, or, How We Became Unprepared," Cultural Anthropology 23 (2008): 399-428.

41 King, "The Scale Politics of Emerging Diseases."

42 King, "The Scale Politics of Emerging Diseases,"67.

43 King, "The Scale Politics of Emerging Diseases," 70.

44 Priscilla Wald, Contagious: Cultures, Carriers, and the Outbreak Narrative (Durham, NC: Duke University Press, 2008), 1. 
45 Wald, Contagious, 2. On the notion of the "rehearsal", see: Maria Zambon and Karl G. Nicholson, "Sudden Acute Respiratory Syndrome May Be a Rehearsal for the Next Influenza Pandemic," British Medical Journal 326(7391) (2003): 669-670.

46 Richard Preston, "Crisis in the Hot Zone," New Yorker (26 October 1992): 80.

47 Laurie Garrett, The Coming Plague: Newly Emerging Diseases in a World Out of Balance (New York: Farrar, Straus and Giroux, 1994).

48 Richard Preston, The Hot Zone (New York: Anchor, 1994), 287.

49 Steven Soderbergh, Contagion (Warner Bros. Pictures, 2011).

50 Wald, Contagious, 10.

51 Keck, Un monde grippé; Frédéric Keck, "Lévi-Strauss and Bird Flu How to Do the Structural Anthropology of a Virtual Catastrophe," accessed May 3, 2015 http:// cirphles.ens.fr/ciepfc/publications/frederic-keck/article/levi-strauss-and-bird-fluhow-to?lang=fr; Frédéric Keck, "Liberating Sick Birds: Poststructuralist Perspectives on the Biopolitics of Avian Influenza," Cultural Anthropology 30(2) (2015): 224-235. For Lévi-Strauss on the mad cow disease, see: Claude Lévi-Strauss, "La leçon de sagesse des vaches folles," Etudes rurales 157-158 (2001): 9-14.

52 Frédéric Keck, "From Purgatory to Sentinel: 'Forms/Events' in the Field of Zoonoses," Cambridge Anthropology 32(1) (Spring 2014): 47-61.

53 Wald, Contagious, 39; Caduff, Pandemic Prophecy; see also: Christos Lynteris, "The Prophetic Faculty of Epidemic Photography: Chinese Wet Markets and the Imagination of the Next Pandemic," Visual Anthropology 29(2) Medicine, Photography and Anthropology (2016): 118-132.

54 Marry Shelley, The Last Man (Ware: Wordsworth, 2004 [1826]). For discussion of Shelley's book, see: Jennifer A. Wagner-Lawlor, "Performing History, Performing Humanity in Mary Shelley's The Last Man," SEL Studies in English Literature 15001900 42(4) (Autumn 2002): 753-780.

55 Danowski and Viveiros de Castro, The Ends of the World; Erik Swyngedouw, "Apocalypse Forever? Post-Political Populism and the Spectre of Climate Change," Theory, Culture \& Society 27(2-3) (March-May 2010): 213-232; David L. Levy and André Spicer, "Contested Imaginaries and the Cultural Political Economy of Climate Change," Organisation 20(5) (September 2013): 659-678.

56 Elana Gomel, "The Plague of Utopias: Pestilence and the Apocalyptic Body," Twentieth Century Literature 46(4) Literature and Apocalypse (2000): 409-410.

57 Gomel, "The Plague of Utopias: Pestilence and the Apocalyptic Body," 413.

58 Giorgio Agamben, The Time That Remains: A Commentary on the Letter to the Romans, translated by Patricia Dailey (Stanford, CA: Stanford University Press, 2005); Cesare Pavese, "Concerning Certain Poems Not Yet Written," In Cesare Pavese Selected Poems, translated by Margaret Crosland (London: Penguin, 1969 [1943]).

59 Gomel, "The Plague of Utopias: Pestilence and the Apocalyptic Body," 412.

60 For responses to Caduff's thesis on pandemic prophecy, see "Comments" to his 2014 Current Anthropology paper. For a defense of the non-apocalyptic nature of pandemic prophecy, see: Lynteris, "The Prophetic Faculty of Epidemic Photography."

61 Danowski and Viveiros de Castro, The Ends of the World, 21. For a discussion of this distinction and its application to the post-pandemic condition, see Chapter 5.

62 Walter Benjamin, Reflections: Essays, Aphorism, Autobiographical Writings, ed. Peter Demetz (New York: Schocken), 93.

63 Giorgio Agamben, The Open: Man and Animal, translated by Kevin Attell (Stanford, CA: Stanford University Press, 2004), 83.

64 See: Robin Mitchell-Boyask, Plague and the Athenian Imagination (Cambridge: Cambridge University Press, 2007); Sheila Barker, "Poussin, Plague, and Early Modern Medicine," The Art Bulletin 86(4) (December 2004): 659-689.

65 Claudia Strauss, "The Imaginary," Anthropological Theory 6(2006):322-344. Equally, it cannot be reduced to Jan Starobinski's formula: "[I]t is a power of difference thanks 
to which we represent what is distant and we make distant resent realities" (2001: 206, my translation).

66 Cornelius Castoriadis, The Imaginary Institution of Society (Oxford: Blackwell, 1987 [1975]), 7.

67 Castoriadis, The Imaginary Institution of Society, 7.

68 Henrietta L. Moore, The Subject of Anthropology: Gender, Symbolism and Psychoanalysis (London: Polity Press, 2007), 60. More specifically, regarding the role of the symbolic in the social imaginary, Castoriadis maintained that "The social imaginary is, primordially, the creation of significations and the creation of images and figures that support these significations. The relation between a signification and its supports (images or figures) is the only precise sense that can be attached to the term 'symbolic' and this is the sense in which we are using the term here" (1987: 238). François Dosse (2017: 157, my translation) notes that "Castoriadis does not abandon the dimension of the symbolic, but places it on the side of the instituted society": "Everything that is presented to us in the social-historical world is tied to the symbolic [. . . Institutions cannot be reduced to the symbolic but they can exist only in the symbolic; they are impossible outside a second-order symbolism" (Castoriadis 1987: 117). Contra Lacan the symbolic does not dominate the imaginary, but "is considered as indispensable to the expression of the imaginary" (Dosse 2017: 158, my translation). See also: Olivier Fressard, "Castoriadis, le symbolique et l'imaginaire," In L'imaginaire selon Castoriadis: Thèmes et enjeux, eds. S. Klimis and L. Van Eynde, pp. 119-150 (Brussels: Facultés Universitaires Saint-Louis, 2006). For a recent anthropological approach that again sets the imaginary under the symbolic, see: Maurice Godelier, L'imaginé, l'imaginaire et le symbolique (Paris: CNRS, 2015).

69 Arnaud Tomes, "Introduction à la pensée de Castoriadis," In Cornelius Castoriadis, L'imaginaire comme tel (texte établi par Arnaud Tomes) (Paris: Hermann, 2007), 61, my translation.

70 Cornelius Castoriadis, Figures of the Thinkable, translated by Helen Arnold (Stanford, CA: Stanford University Press, 2007 [1999]), 72-73.

71 Tomes, "Introduction a la pensee de Castoriadis," 99.

72 Tomes, "Introduction a la pensee de Castoriadis," 100.

73 Dilip Parameshwar Gaonkar, "Toward New Imaginaries: An Introduction," Public Culture 14(1) (2002): 6.

74 Tine M. Gammeltoft, "Toward an Anthropology of the Imaginary: Specters of Disability in Vietnam," Ethnos 42(2) (June 2014): 157; Jean-Paul Sartre, The Imaginary: A Phenomenological Psychology of the Imagination (London and New York: Routledge, 2001 [1940]), 216.

75 Nigel Report, “'Imagination Is the Barest Reality': On the Universal Human Imagining of the World," In Reflections on Imagination: Human Capacity and Ethnographic Method, eds. Mark Harris and Nigel Rapport, pp. 3-22 (Farnham: Ashgate, 2015), p. 5.

76 Mathieu Noury (2011) calls this the "Janus face" of Castoriadis' imaginary.

77 Castoriadis, Figures of the Thinkable, 73.

78 Castoriadis, Figures of the Thinkable, 73.

79 Castoriadis, Figures of the Thinkable, 72.

80 Castoriadis, Figures of the Thinkable, 71. On Castoriadis' notion of the institution, see: Johann P. Arnason, "Institution," In Cornelius Castoriadis Key Concepts, ed. Suzi Adams, pp. 101-106 (London: Bloomsbury, 2014); Brian Singer, "The Later Castoriadis: Institution Under Interrogation," Canadian Journal of Political and Social Theory 4(1) (Winter 1980): 75-101; For a discussion of its relation to the institution as developed in anthropology and particularly in Marcel Mauss' work, see: Johann P. Arnason, "Castoriadis and Ricoeur on Meaning and History: Contrasts and Convergences," In Ricoeur and Castoriadis in Discussion: On Human Creation, Historical Novelty and the Social Imaginary, ed. Suzi Adams, pp. 49-75 (London: Rowman and Littlefield, 2017). 
81 George Taylor (2017: 34) clarifies that for Castoriadis the imaginary is creative "because newness not only arises from but also breaks away from the existing social imaginary". For a discussion regarding the idea of creation in Castoriadis, see: Suzi Adams, Castoriadis's Ontology: Being and Creation (New York: Fordham University Press, 2011); Jeff Klooger, "From Nothing: Castoriadis and the Concept of Creation," Critical Horizons a Journal of Philosophy and Social Theory 12(1) (2011): 29-47; Danilo Martuccelli, "Cornelius Castoriadis: promesses et problèmes de la creation," Cahiers internationaux de sociologie 2(113) (2002): 285-305; Nicholas Poirier, L'ontologie politique de Castoriadis Création et institution (Paris: Payot, 2011). On the debate between Ricoeur and Castoriadis regarding the creative or productive nature of the imaginary, see: Suzi Adams (ed.), Ricoeur and Castoriadis in Discussion: On Human Creation, Historical Novelty and the Social Imaginary (London: Rowman and Littlefield, 2017).

82 Suzi Adams (2014: 2) usefully summarizes three presuppositions of autonomy according to Castoriadis: "first, the recognition that society is the source of its own form, meaning and laws; second, the recognition that socially created laws and norms are not given once and for all, and as such can be collectively - and publicly - problematized, interrogated and altered; third, the acknowledgement that there are no pre-given limits to the human realm - apart from very general, existential limits, such as mortality and, as such, the social collective must set its own limits". On Castoriadis' dialogue with Francisco Varela on autonomy, see: "The Imaginary: Creation in the SocialHistorical Domain" (Castoriadis 1997) and "Life and Creation: Cornelius Castoriadis in Dialogue with Francisco Varela" (Castoriadis 2011). For a discussion of the Castoriadis-Varela exchange, see: Suzi Adams, "Castoriadis and Autopoesis," Thesis Eleven 88(1) (2007): 76-91; Angelos Mouzakitis, "Creation ex nihilo," In Cornelius Castoriadis Key Concepts, ed. Suzi Adams, pp. 53-64 (London: Bloomsbury, 2014).

83 Castoriadis, Figures of the Thinkable, 73.

84 Castoriadis, The Imaginary Institution of Society, 75.

85 Castoriadis, The Imaginary Institution of Society, 132-133.

86 Charles Taylor, Modern Social Imaginaries (Durham, NC: Duke University Press, 2003), 23; Florence Hulak, "Que permet de penser le concept d'imaginaire social de Charles Taylor?," Philosophiques 37(2) (Fall 2010): 275; George E. Marcus (ed.), Technoscientific Imaginaries: Conversations, Profiles, and Memoirs (Chicago: The University of Chicago Press, 1994); Sheila Jasanoff and Sang-Hyun Kim (eds.), Dreamscapes of Modernity: Sociotechnical Imaginaries and the Fabrication of Power (Chicago: The University of Chicago Press, 2015). For a review of anthropological applications of the "imaginary", see Strauss (2006). More recently, Steger and James (2013) have developed their own typology of ideologies, imaginaries, and ontologies, which the authors attribute to a Bourdieusian reading of the social. For a discussion of Taylor's approach as a "minimalist" master narrative, see: Vincent Carpanzano, Imaginative Horizons: An Essay in Literary-Philosophical Anthropology (Chicago: The University of Chicago Press, 2004), 7-8.

87 David Sneath, Martin Holbraad and Morten Axel Pedersen, "Technologies of the Imagination: An Introduction," Ethnos 74(1) (2006): 6.

88 Sneath, Holbraad and Pedersen, "Technologies of the Imagination: An Introduction," 5, 6-7. On the "defunctionalisation" of the imaginary by Castoriadis, see: Kathleen Lennon, Imagination and the Imaginary (London and New York: Routledge, 2015).

89 Castoriadis, The Imaginary Institution of Society, 460.

90 Sneath, Holbraad and Pedersen, "Technologies of the Imagination: An Introduction," 6.

91 Sneath, Holbraad and Pedersen, "Technologies of the Imagination: An Introduction," 6.

92 Sneath, Holbraad and Pedersen, "Technologies of the Imagination: An Introduction," 24.

93 The turn has also expectedly led to "empiricist" critiques, encompassing more broadly anthropological fascination with the notion of imagination and the imaginary: 
Damien Stankiewicz, "Against Imagination: On the Ambiguities of a Composite Concept," American Anthropologist 118(4) (2016): 796-810.

94 Theodor W. Adorno, Über Walter Benjamin: Aufsätze, Artikel, Briefe (Frankfurt: Suhrkamp, 1990).

95 Danowski and Viveiros de Castro, The Ends of the World, 4.

96 For discussion of the notions of autonomy and heteronomy in Castoriadis, see: Ingerid S. Straume, "Castoriadis on Autonomy and Heteronomy," In Encyclopedia of Educational Philosophy and Theory, ed. M. A Peters, pp. 1-5 (Singapore: Springer, 2017); Marcela Tovar-Restrepo, Castoriadis, Foucault, and Autonomy: New Approaches to Subjectivity, Society, and Social Change (London: Bloomsbury, 2013). The implications of this tension will be further explored in the Conclusion.

97 Castoriadis, interview to Stella Mane, 1990; audio fragment available www.youtube. com $/$ watch? $\mathrm{v}=\mathrm{N}$ OB6oFAePE

98 Wald, Contagious, 33.

99 It should be noted here that the imaginary is not an altogether "etic" term, as the imagination plays a key role in preparedness policy; for a discussion, see: Andrew Lakoff, Unprepared: Global Health in a Time of Emergency (Berkeley, CA: The University of California Press, 2017), especially pages 23-26. For a discussion of an epidemic exercise mobilizing imaginary pathogens and geographies, see: Marouf A. Hasian, Jr., Representing Ebola: Culture, Law, and Public Discourse about the 2013-2015 West African Ebola Outbreak (Lantham, MD: Rowan and Littlefield, 2016), Chapter 6.

100 Susan Buck-Morss, The Origin of Negative Dialects: Theodor W. Adorno, Walter Benjamin, and the Frankfurt School (New York: The Free Press, 1977), 58.

101 Buck-Morss, The Origin of Negative Dialects, 74.

102 Buck-Morss, The Origin of Negative Dialects, 77.

103 Max Pensky, "Method and Time: Benjamin's Dialectical Images," In The Cambridge Companion to Walter Benjamin, ed. D. S. Ferris, pp. 177-198 (Cambridge: Cambridge University Press, 2004), 186.

104 Marc Berdet, "Chiffonnier contre flâneur: Construction et position de la Passagenarbeit de Walter Benjamin," Archives de Philosophie 75 (3) (2012):425, 428; my translation, as approved by the author. Not mentioning the figure of the ragpicker, Judith Okely (2012: 54) comes close to a similar formulation, when she employs André Breton's notion of disponibilite so as to describe the need for the anthropologist's openness to unexpected encounters.

105 Theodor W. Adorno in Gerhard Richter, "A Matter of Distance: Benjamin's One-Way Street through the Arcades," In Walter Benjamin and the Arcades Project, ed. B. Hanseen, pp. 132-256 (London and New York: Continuum, 2005), 148.

106 Frédéric Keck, "Ebola, entre science et fiction," Anthropologie \& Santé 11 (2015) doi:10.4000/anthropologiesante.1870, my translation.

107 Philippe Descola, La Fabrique des images: Visions du monde et formes de la representation (Paris: Musée du quai Branly/Somogy, 2010); Carlo Severi, L'objet-personne: Une anthropologie de la croyance visuelle (Paris: Rue d'Ulm, 2017).

108 Keck, "Ebola, entre science et fiction," my translation.

109 Vincent Crapazano (2004: 1) reminds us that anthropologists have habitually been interested in imaginary products rather than processes.

110 Anders, Le temps de la fin, 75, my translation. 


\section{The end of the world as we do not know it}

"Apocalypse warning: Ancient viruses could REAWAKEN and cause 'global epidemic", reads a sheet of the British Daily Express from May 10, 2017. ${ }^{1}$ Referring to fears that an emerging pathogen may lead to a human extinction event, the apocalyptic trope of the newspaper's title is not a monopoly of tabloids and science fiction novels or films but is widely employed by popular science outlets as well as by epidemiologists and public health officers. Moreover, this idiomatic consensus also informs scholarly works, where technoscientific visions of human extinction (resulting from pandemics, climate change, EMP, or other drivers of existential risk) are commonly grouped together under the overarching category of the apocalyptic. As part of what we may call normative catastrophism, this trope may be suspected as being conducive to the normalization of visions of human extinction: an operation that not only reduces the latter's distinctly latemodern character but also obscures its real consequences for humanity's relation with the world. This is for two reasons. On the one hand, if human extinction is simply another apocalyptic variant, then the tools we need for understanding it may safely be assumed to be already in place, forged over decades or indeed centuries by theologians, historians, and, more recently, anthropologists. And, on the other hand, if this reduction holds true, no matter how scientific or secular their appearance, the net effect of visions of human extinction can be safely relegated to that of a cultural relic: a persistent but ultimately moribund Biblical heritage. ${ }^{2}$

However, this critique of human extinction as a secular apocalypse harbors a double danger: the dismissal of any and all apocalyptic or eschatological aspects of human extinction and the repudiation of any significance or impact of religious meanings and affects in the modern world. ${ }^{3}$ What then becomes necessary is to approach this question within a robust framework of what it means to be apocalyptic - a framework that goes beyond the simple, etymological formulas: "an end with revelation", or something that "produces a new insight through destruction", or "a process in which something concerning the end of the world gradually becomes apparent". ${ }^{4}$ For if the revelatory end of the world is indeed an important aspect of the apocalyptic, it is not an adequate condition of it, insofar as it tends to obscure the diverse meanings and experiences of the world, the end, the revelation, and the relation between them across different societies and cultures. 
The apocalypse, millenarianism, and eschatology have traditionally been the subject of the anthropology of religion. However, recent anthropological literature has begun to expand the examination of the apocalyptic to other spheres of social life. Following a trend well established in the humanities, where the study of the end of the world has extensively preoccupied literary and film studies, anthropologists have recently begun exploring what Roy Scranton in his entry on "apocalypse" for Cultural Anthropology's Lexicon has broadly described as "fantasies of the end". If climate change and the Anthropocene have been the main spheres of interest, the discussion of the apocalyptic has not been absent from anthropological accounts and critiques of "outbreak narratives". 6

Anthropological discussion of the apocalyptic or non-apocalyptic character of the next pandemic has largely revolved around Carlo Caduff's notion of pandemic prophecy. A quick look at this debate is revealing of not only the prospects of but also the challenges faced by anthropological approaches of the "apocalyptic potential" of the next pandemic. ${ }^{7}$ Describing discourses centered on the anticipation of a catastrophic influenza pandemic, the notion of pandemic prophecy has been applied by Caduff in order to examine what makes some "scientifically inspired visions of the future [...] more reasonable and authoritative than others". ${ }^{8}$ Contextualizing within wider trajectories of North American apocalyptic thinking and anthropological readings of the "emerging economy of disaster capitalism", Caduff proposes that at the heart of pandemic apocalypse lies a "cosmology of mutant strains". ${ }^{9}$ This is a cosmology that pictures humanity as faced with a threat that is paradigmatically asymmetrical: nowhere and everywhere, at the same time present and absent. "Ever-changing and everevolving", "unforeseeable and unpredictable", emerging pathogens occupy a unique position of ontological and temporal exceptionality: they are yet-to-be, and yet they are already ahead of us. ${ }^{10}$ By means of investing on viral indeterminacy, this cosmology of existential risk has thus led to a "normalization and naturalization of the unknown [. . . ] as an ontological given": a process of normative catastrophism, where "faith dwell[ing] in reason has morphed into the mythic ground for the biopolitics of pandemic preparedness". 11 "Precaution", writes Caduff,

has become a solid ground for dire prophecy and the thrill of terror, allowing experts and officials to commit a leap of faith and proceed as if the most frightening scenario was about to come true. In the political economy of disaster capitalism it is always better - ethically, politically, economically, and institutionally - to assume that the apocalypse is nigh. ${ }^{12}$

Responding to Caduff's paper, James Faubion has objected to his use of the term "prophetic" and its situating within North American apocalyptic traditions. Faubion notes that Caduff identifies the apocalyptic too closely with doom, overlooking its soteriological aspects. ${ }^{13}$ Consequently, he casts doubt as to whether the vision of disease emergence developed by virologists corresponds to an apocalyptic 
vision of the end, as the temporality it reinforces is more one of institutionalized "repetition of indefinite pace, rhythm or duration, a constant recycling of catastrophe and remediation and catastrophe again". ${ }^{14}$ This is an important critique, which rhymes with Elana Gomel's earlier reading of pandemic discourses. In her paper "The Plague of Utopias: Pestilence and the Apocalyptic Body", Gomel argued against an apocalyptic reading of pandemic scenarios. For whereas, she claimed, the apocalypse entails a temporality structured around an absolute end and a new, counter-temporal beginning, the next pandemic is "an accumulation of repetitive episodes, deferring any kind of meaningful closure". ${ }^{15}$ In other words, whereas apocalyptic thinking relies on and fosters a telic (if not necessarily terminal) imaginary, the pandemic imaginary is "a cyclical plot" of meaningless endlessness. On the one hand, Gomel argued, this strips the next pandemic of any redemptive quality. And on the other hand, it abandons it in the realm of monotonous repetition, so that the end endures as a fantasy in an almost Lacanian sense of the term: as something that is constituted through its constant deferral. Indeed, this places the next pandemic within a broader cluster of end of the world variants, which, while transcending any dichotomy between immanence and imminence, retain the potency of what Frank Kermode has identified as the sense of living at a threshold: a transitory period that, to use Matilde Nardelli's commentary on cumulative ends, "has not only been "elevated into an "age" or saeculum in its own right' but moreover, indeed, into an age that 'has become endless" ". ${ }^{16}$ Crucially, this has also been described to be the nature of climate-change-related ends of the world, which Erik Swyngedouw, following broader approaches of the so-called postmodern apocalypse (such as elaborated by Jay Martin, Richard Dellamora, Elizabeth Rosen, Klaus Scherpe, and Brent Peterson, among others), has designated as an "apocalypse forever": a condition that in Jacques Derrida's oft-quoted formula is "an apocalypse without apocalypse, an apocalypse without vision, without truth, without revelation". ${ }^{17}$

Is this, however, good enough reason for us to conclude with Faubion that the next pandemic is not an apocalyptic event, or at least an event with an apocalyptic potential ${ }^{18}$ Having defended this position myself elsewhere, I would like to reconsider, by examining briefly the two pillars of this argument. ${ }^{19}$ First, it is clear that visions of pandemic-driven human extinction do not generally dwell on redemptive aspects of a post-pandemic world (though see Chapter 5 for some such options). Rather than rendering the next pandemic non-apocalyptic, however, this would place it within the large corpus of visions of what is generally known as an apocalypse without Kingdom (or non-millenarian apocalypse). Second, what is problematic with both Faubion and Gomel's analyses is that they overlook the fact that the "cyclical plot" that we indeed encounter in next pandemic scenarios is also entangled in the culminative plots of a wide range of unambiguously apocalyptic dramas. ${ }^{20}$ What I would like to argue here, as a result, is that we should seek the next pandemic's apocalyptic or non-apocalyptic character elsewhere: to be precise, in the relation between the time of the end and the end of time. 


\section{The time of the end and the end of time}

If, in their recent book on the subject, Danowski and Viveiros de Castro's aim has been to complicate the "end of the world", they have done so by means of a very useful simplification - a programmatic statement of sorts:

Every thought of the end of the world thus poses the question of the beginning of the world and that of the time before the beginning, the question of katechon (the time of the end, that is, the time-before-the-end) and that of eschaton (the end of times, the ontological disappearance of time, the end of the end). ${ }^{21}$

As we will see in the following chapters, it is undoubtedly true that one of the key mythic operations of human extinction relates to the fact that, as an "end of the world", it "retroprojects a beginning of the world and, by the same token, humankind's future fate carries us back to its inception". ${ }^{22}$ This entails not simply a script of the world before us but indeed that much rarer vision (in Western thought at least) of us before the world, as a world the relation to which we master (a "world for man", in Danowski and Viveiros de Castro's typology). ${ }^{23}$ However, this does not fully cover the area opened up by the crucial question regarding the relation between katechon and eschaton, which needs to be examined more closely, especially with regard to the temporal structure it entails.

The two terms appear in Paul's infamously enigmatic second epistle to the Thessalonians, where the apostle (if the authenticity of the letter is to be sustained) refers to a power or person that restrains the full manifestation of anomy (katechon): a condition that will in turn be met with the Second Coming of Christ (parousia) - that is to mean, the end of time (eschaton). ${ }^{24}$ Forming the basis for extensive reflection by modern political theorists, to/ho katechon (the noun appears in both masculine and neutral form) demarcates a temporal state that is simultaneously the time that remains until the Second Coming and the time of parousia's delay. ${ }^{25}$ Still, taking to heart Lietaert Peerbolte's warning that "the vagueness of the terms used is intentional", we should not overlook other meanings of the word in Greek, which are often silenced by twentieth- and twenty-firstcentury political exegetes ${ }^{26}$ : for the verb katechein does not simply or primarily mean to slow down, to withhold, or to delay (literally, to koluon, in the reading of the term by John Chrysostom) but also to own or to rule over something, including, metaphorically, to occupy a particular space or territory or to know something. ${ }^{27}$ In other words, it is a term that in so many ways embodies not sovereignty (as is the common political-theoretical interpretation shared by Agamben, Cacciari, Esposito, and Schmitt) but instead a relation of mastery: over objects, animals, humans, space, and knowledge. ${ }^{28}$ It seems then that the resistance of katechon to the realization of anomy derives from their interrelation as an opposition not between sovereignty and "lawlessness" (as anomy has been consistently translated in English following the King James Bible) but between mastery and its loss 
instead (apoleia - as in "the son of perdition", the person embodying anomy in the same epistle). In these terms, the relation between the time of the end and the end of time may be said to be mediated by a state of anomy defined as a loss of mastery.

Lest being suspected of twisting theology (and indeed political theology) to our analytical aims, we need to remember here that the notion of anomia (not to be confounded with Émile Durkheim's later sociological elaboration of anomie), so central in apocalyptic thinking with regard to the relation between the time of the end (katechon) and the end of time (eschaton), reached a landmark elaboration in the first historical work reflecting on the social impact of a disease outbreak: Thucydides' History of the Peloponnesian War. ${ }^{29}$ Perhaps no other description of an epidemic has influenced the way we perceive, understand, or dramatize outbreaks more than Thucydides' account of the so-called plague of Athens. ${ }^{30}$ Iterated in hundreds of texts, paintings, movies, and photographs, it is the first and perhaps most iconic description of an epidemic disease as a natural phenomenon and, at the same time, as a catalyst of social collapse. As the unnamed disease (loimos) struck in the second year of the Peloponnesian War (430 bce), Athens was gripped in a "wild disorder" of mass mortality: with people staggering to their death in the streets of the city, human cadavers lay one upon the other, "and halfdead corpses were seen tumbling over each other". ${ }^{31}$ The "plague" led to a total "neglect alike of sacred and social duties" and to the violation of even the most basic burial rites. "Men buried [others] just where and how they could", while many, Thucydides notes in a harsh tone, turned to shameless means for disposing their friends:

For some, resorting to funeral piles which were raised for others, would, before they were completed, lay their own corpses thereupon, and set them on fire. Others, when a corpse was burning, would toss upon the pyre another, which they had brought with them, and go their way. ${ }^{33}$

This description of social meltdown marks the pinnacle of Thucydides' "enargic" force; that is, his ability to bring the reader affectively into the scene of his narrative. ${ }^{34}$ In light of imminent and indiscriminate death, widespread disregard for law and custom (the way anomia was defined), and the public display of indulgence, which in the Athenian democracy had hitherto remained private matters, led the city to be gripped by the rule of transitory pleasure. As a moral and political event, the neglect and violation of funerary rites functioned as an index of an instantaneous anthropological transformation of Athenian society into an anomic condition. In short, Thucydides tells us, "whatever any person thought pleasurable, or such as might in any way contribute thereto, that became with him both good and useful". 35

It is indeed no accident that the story of the anomy brought about by the plague immediately (and dramatically, as Castoriadis notes) follows the moral and political apex of Thucydides' History, the "mise en scène of the [civic] imaginary of Athens" that was Pericles' Epitaph ${ }^{36}$ - for here, as Clifford Orwin has stressed, 
lies the key to the narrative: an ethical inversion, a swift turn from the very definition of the polis as a domain of virtue, in Pericles' oration, to the suspension of society itself, not in terms of a Hobbesian leveling or equalization nor, however, in the sense of some bodily or bestial defiling of the human spirit but instead as a state beyond the fear of death and the hope of survival where what is good and what is useful become indistinct. ${ }^{37}$

What I want to argue here is this: if the pandemic imaginary does indeed set in operation apocalyptic visions in the strict sense that it configures the relation between the time of the end and the end of time as a relation involving the activation of a state of anomy, this is only insofar as the apocalyptic variant it relies upon is always already dependent on classical visions of epidemic catastrophe. In other words, if the contemporary pandemic imaginary is indeed apocalyptic, this may be said to be only to the extent that the variant of the apocalypse on which it relies is itself depended on historically specific, medico-juridical notions of anomy and of the loss of humanity when a given society is faced with an epidemic. With this genealogical entanglement in mind, the question then arises: to what extent does the next pandemic constitute a specifically apocalyptic form of time ? $^{38}$

First, we have already briefly seen that the next pandemic does not mark an end in the eschatological sense of either an absolute termination (apocalypse without Kingdom) or a redemptive one (apocalypse with Kingdom). Though the particulars of the post-pandemic condition will be discussed in detail in Chapter 5 , it is worth noting here that if this indeed is the case, it is because the latter entails neither a total eclipse of humanity (total biological extinction) nor a realization of humanity's destiny (humanity entering a new realm of existence). Instead, it signals the demise or regression of humankind into a dehumanized existential state: an ex-human condition. ${ }^{39}$

Without further delay, we can thus say that what challenges the next pandemic's eschatological status is not its "cyclical plot", as Faubion and Gomel would maintain: for through patterns of anticipation, prophecy, and delay - what Boman has called "the fugue-like structure of spiralling septets" of eschatology - all JudeoChristian apocalyptic variants may be said to share to a greater or lesser degree this temporal trait. ${ }^{40}$ Instead, what sets the next pandemic apart from eschatological temporality is that the end envisioned through the former is a regressive one, an end that reveals a vital but hidden aspect of humanity's relation to the world not through the mirror of a future edge of existence (eschaton) but instead through the return to a mythic, political-ontological past, which is none other than a permanent state of anomy: humankind aimlessly roaming the earth; listless beings emptied of any purpose, goal, or destiny; a species hollowed out of its being, neither fit to simply live in the world nor fit to shape it to its needs or desires.

Second, we need to examine the katechontic aspect of this end of the world. If in Christian apocalyptic variants the relation between the time of the end and the end of time is punctuated by the delay of anomy, does the next pandemic similarly involve a katechon in a meaningful way? For those inclined toward a "sovereign" reading of katechon, this may be a tempting interpretation, and it could indeed have been the case if organizations like the US Centers for Disease Control and 
Prevention (CDC) and the World Health Organization involved in the anticipation and response to pandemic threats claimed an ability to withhold the "coming plague". ${ }^{41}$ However, by definition, as anthropologists have shown, pandemic preparedness can neither prevent nor delay the next pandemic; it can simply make us ready for it. ${ }^{42}$ Hence, if its faculty is indeed prophetic, it is still not katechontic, for the relation of mastery entailed is not one capable of delaying or restraining the end of the world.

In order to make better sense of the two incongruities between the next pandemic and the apocalypse as temporal forms and of the relation between them, we need to focus on a radical reversal that underlines the latter's constitutive temporal metaphysics.

\section{Temporal reversal}

If, in terms of what Giorgio Agamben calls "the structure of eschatological time", anomy is an intermediate threshold between the time of the end and the end of time, in the pandemic imaginary it is the next pandemic that fills this role, with anomy being no less than the "end" in sight. ${ }^{43}$ What we have here as a result is a mythic reversal of the first order:

\section{Katechon [DELAYS] Anomy $\rightarrow$ Eschaton \\ $\Downarrow$ \\ Preparedness [PREPARES US FOR] Next Pandemic $\rightarrow$ Anomy}

What is the significance of this reversal? First, by taking the place of eschaton anomy is transformed into a state without an end. In other words, it takes the place of the endless end of humanity. This transformation of anomy from a threshold between the time of the end and the end of time into the end of time itself marks a distinct configuration of the pandemic-borne end of the world and its temporality. For, by assuming the guise of anomy, the end of time is stripped of any telic meaning. It instead comes to connote an end of human time as an opportune time or kairos; in other words, the end of human time as a time when human agency could be exercised so as to shape or, more generally, achieve an accumulative effect on the world.

Second, by taking the place of anomy as the threshold between the time of the end and the end of time, the next pandemic acquires key temporal characteristics of the latter. For, similar to apocalyptic anomy, whose "mystery" (to mystērion tēs anomias; 2 Thess 2:7) consists in the fact that, according to the Paulian epistle, it is always already here but remains unseen, the "killer virus", or more accurately (as will be examined in the next chapter) viral emergence, is depicted in epidemiological narratives as being imperceptibly already in place, lurking in some East Asian poultry market or making an interspecies salto mortale in a remote corner of the African bush.

Let us then examine the two impacts of the temporal reversal, as this operates in the human extinction variant of the pandemic end of the world, more closely. 


\section{Humans without a world}

To understand the first impact of the temporal reversal constitutive of the pandemic end of the world, it is instructive to draw a comparison between the latter's non-telic temporal structure and the one instituted through the threat of nuclear catastrophe. For Günther Anders, who first systematically problematized the relation between the time of the end and the end of time in this terrain, the US nuclear attacks on Hiroshima and Nagasaki, in August 1945, marked a radical anthropological transformation in that they reconfigured the human species from a "species of mortals" into a "mortal species". ${ }^{44}$ This they did by ushering in an era where a new possibility arose: that of an event that would mark not simply a moment after which humanity will not be, but a moment after which humanity will have never been, for nothing and no one would be left to witness its having-been.

Following Danowski and Viveiros de Castro's analysis of Anders, this shift indicated a future that is radically other than the past, in the sense that it is "notours, a time that demands our disappearance in order to appear". ${ }^{45}$ As a result, it does not simply describe the condition succinctly described by Ernesto De Martino in his work on "cultural apocalypses", where what is at stake is the world that may but should not end. ${ }^{46}$ Instead, it is a vision of the world as a world that has already ended, "even if we must fear the moment when this end will be fully realized in the nuclear apocalypse" 47 _ not in the sense, as Jean Baudrillard would have it, that "the very idea of the catastrophe is impossible", nor because we have entered some sort of mediatic state of post-apocalyptic simulation. ${ }^{48}$ Instead, for Anders - whom Jean-Pierre Dupuy has rightfully acclaimed as "the most profound and the most daring of the thinkers who contemplated the great catastrophes of the twentieth century" - Hiroshima is a "world condition" because at any moment it can be rendered not just a reality in this or that place but a total reality instead $^{49}$ : an event that engulfs all human existence and thus places humanity within the bounds of a new temporal ontology: that of the "end time" (Endzeit). ${ }^{50}$ Following Jason Dawsey's lucid reflection on Anders' work, this marks a temporal framework that "would not give way to a subsequent, different era, just as recorded history had always done. That traditional understanding of historical change had expired in the ruins of Hiroshima". ${ }^{51}$ Anders' vision did not simply entail thinking humanity as engulfed in an enduring state of precarity or living in the ruins of capitalism à la Anna Tsing. ${ }^{52}$ Rather, it marked a radical departure from such "posthumanist" critiques and their Romantic residue, as it called for the imagination of the unimaginable: the real and final end of humanity as a condition that has been rendered already obsolete by its own devices - what Anders called the "Promethean gap" between humans and their more-than-human machines. ${ }^{53}$

Whether or not Anders' observations were shared ethnographically at the various ebbs and flows of the Cold War (in terms of how different people across the globe experienced the threat of nuclear annihilation), his writings still managed to draw out a crucial anthropological incongruity: what he called the "imaginationdeficit" regarding nuclear war. ${ }^{54}$ What was the object of this deficit, forming the pivot of what Anders considered to be our "blindness to the apocalypse"? 
It was surely not, primarily at least, the material (or if we prefer, spatial) impact of nuclear war, for this had already become quite apparent in the annihilation of Hiroshima and Nagasaki and only required a scalar projection to be envisioned on a global scale. In the years that Anders composed his various writings on the subject, science fiction novels and movies as well as popular, televised docudramas depicted the effect of nuclear war in the form of Mutually Assured Destruction (MAD) and (after 1982) of the so-called nuclear winter to follow. What, however, remained unimagined if not unimaginable was the temporal impact of this omnicidal event. This was, following Timothy Morton's work, "hyperobjective", or, in Anders' own terms, "over-liminal" (überschwellige) - the latter being a term used to describe "phenomena that cannot be grasped and intellectually assimilated because they outgrow the size of any of the sensual/conceptual nets". ${ }^{55}$

Yet in all its pessimism, this nuclear predicament did hold a germ of hope: a hope in humanity's capacity to develop the ability to grasp the ungraspable ontological consequences of the nuclear end by means of an expansion of our "moral fantasy". ${ }^{56}$ Indeed, human agency must be recognized as a key principle of nuclear variants of the end of the world. This is true both in terms of the decision to "press the button" and in terms of the counter-decision of unilateral disarmament whether this was to be taken by sovereign powers or by a global pacifist movement that would overturn the latter through an act of universal stasis. ${ }^{57}$ For, as de Martino claimed, "nuclear war is the end of the world, not as risk or as a mythoritualist symbol of reintegration, but as a technical gesture, lucidly prepared by the mobilization of the entirety of science's resources within a political frame that coincides with the death instinct". 58

If this was an apocalypse without an eschaton, as the Italian anthropologist argued, it was still an apocalypse insofar as it included the utopian possibility of a counter-parousia: that of the cancellation of nuclear threat and the ushering in of ecumenical reconciliation and world peace. This is not, however, the case for the next pandemic, for as a naturalized end of the world, its realization requires no human decision and may be stopped by no human agency. Moreover, because it institutes the coming of anomy, not as stasis but as the loss of human mastery, it is not only something that cannot be decided but also the very event that marks the end of human agency itself as humankind's species-being and as an organizing principle of the world.

What then of the post-pandemic future? As will be discussed in detail in Chapter 5 , in contrast to nuclear variants of the end of the world, this does not signify a time when we will not have been but a time when we, still in existence biologically speaking, will no longer be ourselves: a time of ex-humans. ${ }^{59}$ Neither biologically extinct nor absorbed into our environment, the post-pandemic future hence falls, strictly speaking, outside both "end of the world" scenarios identified by Danowksi and Viveiros de Castro - "the world without us" or "us without the world": for it marks an era where humankind is deprived not of a livable environment (and is thus doomed to survive in the ruins of its hubris) but of mastery, as its proper being in the world. It is thus not an era of "us without the world" but rather, and more bleakly, of "us without $a$ world" - a time marked by a "subviving" humankind (to use Béla 
Tarr's useful term salvaged by Danowski and Viveiros de Castro) without a devitalization of the environment, an era where the world itself continues to flourish but where we are no longer ourselves precisely because the world is no longer ours. ${ }^{60}$ If the nuclear end marked an end of the world as such, that is, for no particular subject but in and of itself, the next pandemic marks an end of the world only for us and as a world for us. In simple terms, if nuclear catastrophe ultimately marked the end of all existing and future planetary life - "the end of ends" in Joseph Masco's succinct formulation - the next pandemic exclusively marks the extinction of humans or, to be precise, the loss of our supposed species-being: mastery. ${ }^{61}$

\section{The mystery of emergence}

I will be returning to the question of ex-humans in later chapters. At this point it is important to go back to our mythic reversal and examine its second implication, already noted above: on the "mystery" faculty of the next pandemic. Let us briefly look at a recent example that may allow us pick up the thread that leads us to the crossroads of this labyrinth of the pandemic imaginary.

In late April 2017, 28 people reported ill in the Liberian county of Sinoe. Before long international news reported the death of 12 , noting the alarm of the WHO at a "mystery illness" that appeared to have just emerged. Of great concern was the fact that the victims of the "new disease" had all attended the funeral of a religious leader - a social event that has been specifically indicted in the course of the recent Ebola outbreak in the region as a "cultural vector". ${ }^{62}$ This language, describing what a few days later was, less dramatically, dismissed as a case of poisoning, reflects not an isolated incident but the temporal structure of disease emergence in its pandemic potential. In the CDC's account of the 2003 SARS pandemic, itself initially described as being a "mystery disease", we read:

Without question, future mystery illnesses will emerge. The questions will be the same - what is causing the illness, where did it come from, can it be contained, who is at greater risk? The cost in lives and economic upheaval from future mystery illnesses will depend, in part, on how quickly we can detect the threat and answer the questions of life and death. ${ }^{63}$

One mystery illness following another: this may appear easy to dismiss as simply a sensational idiom meant to appeal to a broad readership of crime novels or audiences of whodunit TV series. However, taking this serial "mystery" seriously may lead us to a better understanding of the temporal form of the next pandemic.

First, the emphasis on the "mystery" of disease emergence should be seen as part of what Carlo Caduff has described as the constitutive "logic of seriality" of the next pandemic, as a temporal structure that depends on "sedimentation and proliferation":

What, then, is the next? The next figures in the now not simply as an index of the future. The next is imagined in a particular way: it's what's immediately 
following or succeeding; it's what's coming after in a series or sequence of potentially surprising events. But the next has not only a temporal meaning. What's next is near in place and close at hand. ${ }^{64}$

While this is indeed clear in the CDC's epidemiological reasoning regarding "future mystery illnesses", we should not simply conclude that the pandemic imaginary entails a vision of a series of sequentially replaceable mystery illnesses. The mystery here concerns not just each deferred pandemic candidate (SARS, MERS, Ebola, etc.) but the arcane heart of the next pandemic: disease emergence. In order to grasp the importance of this, we first have to detrivialize the notion of "mystery" by drawing a sharp distinction between it and what is simply "mysterious". What this entails is focusing away from the "mysterious" nature of new pathogens: their supposed ability to emerge out of the blue, to "go back to nature" undetected, to evade our biosecurity surveillance mechanisms, to deceive our immune system, or, more broadly, to "take over and wreak havoc in much more complex and sophisticated beings". ${ }^{65}$ This is pivotal as, under the influence of pioneering works in the deconstruction of AIDS/HIV pandemic narratives, the aforementioned set of traits has attracted the critical attention of medical anthropologists, sociologists, and literary and medical humanity scholars. ${ }^{66}$ However important this may be in understanding scientific configurations of AIDS/HIV as well as contemporary immunological discourses, it is crucial to underline here that the notion that pathogens are "mysterious" is neither new nor particular to the doctrine of disease emergence and the pandemic imaginary.

During the late nineteenth and early twentieth century, the institution of "germs" as pathogenic agents in medical science was entangled with ideas about these being not simply invisible to the naked eye but also able to elude the technologies employed to make them visible (microscopes, statistics, etc.). ${ }^{67}$ Configured as elusive, and imbued with malicious cunning, pathogens like plague or typhus were seen as prone to hide from and trick humanity's latest medical science. Plague's pathogenic agent, Yersinia pestis, to take an example that has extensively preoccupied my own research, was believed to be able to escape detection and eradication by means of an array of strategies. These included its supposed ability to hide in the soil, where it would acquire an undetectable, attenuated form, waiting for the right time to strike back at a human population, or its equally frustrating (and, as far as we understand today, unsubstantiated) ability to acquire another "phantom" form: that of so-called pestis minor or pestis ambulans, which allowed it to hide in human bodies (especially those of native subjects in the tropics), disguised as a relatively benign febrile disease. ${ }^{68}$

Now, whereas this indicates that, as medical categories, "germs" (be these viruses or bacteria) emerged as always already "mysterious", it equally comes to show that this trait was not connected to an imagination of their agency as being in any way "extinctive" (i.e., leading to species extinction). Whereas fin du siècle discourses on pandemics did closely associate the spread of disease with a threat to maritime trade, social order, family life, imperial power, and nation-building, there is no indication that this threat was perceived or acted upon scientifically 
or governmentally as one that concerned the survival of the human species. Of course, fictional works (that we would today call "science fiction") imbued with such "sense of an ending" were already in place at least since the first epidemic novel, Mary Shelley's The Last Man (1826). ${ }^{69}$ However, while Edgar Allan Poe's Mask of Red Death (1842) or Jack London's Scarlet Plague (1912), to take two famous examples, may have caused popular sensation or fueled existential contemplation, they did not reflect a scientific culture or biopolitical agenda regarding pandemic threats. ${ }^{70}$ In tandem with broader colonial anxieties at the time, even when envisioned as a potential return of the Black Death, pandemics were supposed to be a peril to empire, nation, or "Western civilization" but not to humans as a species. Thus, to paraphrase Mark Harrison, these were pandemics before existential risk, events of catastrophic but not "end of the world" potential. ${ }^{71}$

Rather than this being simply a matter of scale, I would like to argue that it marks a biopolitical and ontological discontinuity whose particularities (especially regarding zoonosis as the supposed source of the next pandemic) will be examined in the next chapter. For now what is crucial is to stress that the scientific idea of the pandemic, as this emerged by the end of the nineteenth century, was in no way concurrent with ideas of it as a potential source of human extinction. The latter only arose in scientific literature in the 1990s. As a result, when examining the "mystery" faculty of the next pandemic, we need to consider its place in the process of (to once again paraphrase Harrison) remaking pandemics as existential risk phenomena. ${ }^{72}$ To do this, I would like to argue that we should here take "mystery" seriously. Let us then go back to our mythic reversal:

\section{Katechon [DELAYS] Anomy $\rightarrow$ Eschaton \\ $\Downarrow$ \\ Preparedness [PREPARES US FOR] Next Pandemic $\rightarrow$ Anomy}

If in apocalyptic terms "to understand the mystery of [anomy] means [...] to understand something that concerns the eschaton", in terms of the reversed temporality of the pandemic imaginary, to grasp disease emergence as the mystery of the next pandemic is to grasp something concerning anomy, that is, the loss of human mastery. ${ }^{73}$ Following Agamben's retake on Odo Casel's liturgical reading of mysterion, we should consider this mystery to be not simply the hidden truth of disease emergence - the natural laws of viral mutation, virulence, spillover, and so forth - but more crucially a natural praxis, a process through which nature dramatizes its own immanence, and, at the same time, the way in which the natural is "efficaciously actualised in the world". ${ }^{74}$

Rather than seeing this epidemic drama as a process where nature unleashes its viral armies against humanity in the guise of a microbiological Gigantomachy, we here need to consider the depotentialization of human agency brought about by the next pandemic as the result of nature's actualization of human nature. What lurks at the heart of the mystery of the next pandemic is no less than a tension between the nature of nature and the nature of human nature. This tension sets in motion a paradoxical ontological process: that of de-anthropogenesis 
through the activation of human nature. In simple terms, the next pandemic is seen as an event that initiates a process of unbecoming human by means of forcing humans to express their supposedly true nature. This is the mystery at hand: if humanity's demise is nature's default operation, this is brought about not merely by the latter facing humanity with a formidable microbiological agency that is asymmetrically more pervasive, elusive, virulent, or "viral" (in terms of the communicative doxa of late capitalism) than humans. It is rather brought about by means of this agency operating on human nature itself (i.e., on an ontological level) in a way that actualizes humankind's supposed propensity for dehumanization in the name of survival. In this way, in the pandemic imaginary, humans and viruses are entangled in a manner that goes far beyond current ecological or One Health frameworks of interspecies existence. Their being is opposed and complementary on a mythocosmological plane where the interrelation between humanity and nature is seen, at one and the same time, as the origin and the end of the world.

\section{Humanity, nature, and world}

In conclusion, if the political ontology of the next pandemic is non-apocalyptic, this is not because it bears no relation to apocalyptic rationalities as such but because it reflects a reversal in the temporal structure inherent to apocalyptic ends of the world: the relation between the time of the end and the end of time. This reversal, which should properly be classified as mythic, has two key ramifications on the way in which humanity is configured vis-à-vis pandemic-borne extinction.

First, it impacts humanity's relation with the world, for it configures the end of humanity neither as a condition of the world without us nor as a condition of us without the world. Rather, by replacing the realm of the eschaton with a perpetual state of anomy, it envisions an ex-human future: a post-pandemic time where instead of the world or the human species being extinguished per se, it is the relation between them, as a relation mastered by humans, which has been irreparably severed. This institutes a novel mythocosmological variant: the end of the world as a relational end.

Second, as a process that entails a transposition of the apocalyptic faculty of "mystery" from anomy to the next pandemic, the mythic reversal institutes a rapport between nature and humanity (or indeed the nature of nature, and the nature of human nature) that fosters a vision of nature as a force working through humans, or to be precise through what makes us human, so as to unravel our humanity.

As a result, pandemic extinction reflects neither a vision of an apocalyptic end of the world as such nor, however, an "exhausted" apocalyptic potential..$^{75}$ Instead, it reflects a mythic reversal of apocalyptic temporality whose efficacy lies with the way in which two vital sets of relations - between humans and the world, and between humans and nature - are discharged of the organizing principle characterizing what we may call the modern human project: mastery. 


\section{Notes}

1 Sean Martin, “Apocalypse Warning: Ancient Viruses Could REAWAKEN and Cause Global Epidemic," The Express, May 10, 2017, accessed May 12, 2107 www.express. co.uk/news/science/802779/Apocalypse-warning-Ancient-virus-arctic-permafrost. For a discussion of ideas regarding "killer viruses" melting out of ice, see: Frédéric Keck, "Stockpiling as a Technique of Preparedness: Conserving the Past for an Unpredictable Future," In Cryopolitics: Frozen Life in a Melting World, eds. Joanna Radin and Emma Kowal, pp. 117-142 (Cambridge, MA: MIT Press, 2017); Joanna Radin, "Never Ending Stories: Narrating Frozen Evidence of Infectious Epidemics Past," Somatosphere, Science, Medicine, and Anthropology, June 22, 2016, accessed June 30, 2016 http://somatosphere.net/2016/06/never-ending-stories-narrating-frozen-evidence-ofinfectious-epidemics-past.html; on "frozen pathogens" as zombies, see: Robinson Meyer, "The Zombie Diseases of Climate Change: What Lurks in the Arctic's Thawing Permafrost?," The Atlantic, November 6, 2017 www.theatlantic.com/science/archive/ 2017/11/the-zombie-diseases-of-climate-change/544274/

2 This reduction often takes the functionalist aspect of the reading of the "modern apocalypse" instituted by Frank Kermode in his influential The Sense of an Ending (1966), which, as Richard Webster (1974) has noted, "proceeds from an a priori assumption that the central purpose of the apocalyptic is to provide an image of "concord"".

3 Writing about the distinction of apocalypticism and eschatology, Bernard McGinn (1979: 4) notes that "there is an important difference between a general consciousness of living in the last age of history and a conviction that the last age itself is about to end [. . .] between viewing the events of one's own time in the light of the End of history and seeing them as the last events themselves".

4 Evan Calder Williams, Combined and Uneven Apocalypse (Washington, DC: Zero Books, 2011), 242, n. 1; Dietmar Kamper, "Between Simulation and Negentropy: The Fate of the Individual in Looking Back on the End of the World," In Looking Back at the End of the World, eds. Dietmar Kamer and Christoph Wulf, translated by David Antal, pp. 96-105 (New York: Semiotext(e), 1989), 97; Joseph Masco, "Catastrophe's Apocalypse," In The Time of Catastrophe: Multidisciplinary Approaches to the Age of Catastrophe, eds. Christopher Dole, Robert Hayashi, Andrew Poe and Austin Sarat, pp. 19-46 (New York and London: Routledge, 2015), 26. Such a definition is adopted by Eva Horn in her work on catastrophe; Eva Horn, The Future as Catastrophe: Imagining Disaster in the Modern Age, translated by Valentine Pakis (New York: Columbia University Press, 2018).

5 See, for example: Linda H. Connon, Climate Change and Anthropos: Planet, People and Places (London and New York: Routledge, 2010); Joseph Webster, "The Eschatology of Global Warming in a Scottish Fishing Village," Cambridge Anthropology 31(1) (March 2013): 68-84; Roy Scranton, "Apocalypse," Theorizing the Contemporary, Cultural Anthropology Website, June 28, 2017 https://culanth.org/fieldsights/1151-apocalypse

6 Priscilla Wald, Contagious: Cultures, Carriers, and the Outbreak Narrative (Durham, NC: Duke University Press, 2008). Scott Mitchell and Sheryl Hamilton (2017) have recently attempted to move away from Wald's oft-quoted term, suggesting that "pandemic narratives" is a more appropriate term as regards configurations of the next pandemic. A similar move, also by a scholar of pandemic video games, has been made by Lorenzo Servitje (2016). From an anthropological perspective, the notion of the narrative as employed in both cases remains unsatisfactory as it lacks both performative and instituting potential.

7 On the notion of the apocalyptic potential, see: Calder Williams, Combined and Uneven Apocalypse.

8 Carlo Caduff, "Pandemic Prophecy, or How to Have Faith in Reason," Current Anthropology 55(3) (June 2014): 296. 
9 Caduff, "Pandemic Prophecy, or How to Have Faith in Reason," 300. There is a growing number of works on the "apocalyptic" in North American culture, including works in International Relations (Lahr 2007; Manjikian 2012; Vox 2017), psychoanalysis (Strozier 2012) and criminology (Yar 2014).

10 Caduff, "Pandemic Prophecy, or How to Have Faith in Reason," 301.

11 Caduff, "Pandemic Prophecy, or How to Have Faith in Reason," 304, 302, 301.

12 Caduff, "Pandemic Prophecy, or How to Have Faith in Reason," 304.

13 James D. Faubion, "Untitled" [Comment to Caduff, "Pandemic Prophecy, or How to Have Faith in Reason"], Current Anthropology 55(3) (2014): 306-307. Indeed, as Long (2005) has shown in his analysis of American apocalyptic approaches of the AIDS pandemic, both ends of the spectrum may operate concurrently.

14 Faubion, "Untitled," 307.

15 Elana Gomel, "The Plague of Utopias: Pestilence and the Apocalyptic Body," Twentieth Century Literature 46(4) Literature and Apocalypse (2000): 409-410.

16 Frank Kermode, The Sense of an Ending: Studies in the Theory of Fiction (Oxford: Oxford University Press, 1966); Matilde Nardelli, "No End to the End: The Desert as Eschatology in Late Modernity," Tate Papers 22 (Autumn 2014) www.tate.org.uk/research/publications/ tate-papers/22/no-end-to-the-end-the-desert-as-eschatology-in-late-modernity

17 Erik Swyngedouw, "Apocalypse Forever? Post-Political Populism and the Spectre of Climate Change," Theory, Culture \& Society 27(2-3) (2010): 213-232; Martin Jay, "The Apocalyptic Imagination and the Inability to Mourn," In Rethinking Imagination: Culture and Creativity, eds. Gillian Robinson and John F. Rundell, pp. 30-47 (London and New York: Routledge, 1994); Richard Dellamora, "Introduction," In Postmodern Apocalypse: Theory and Cultural Practice at the End, ed. R. Dellamora (Philadelphia: University of Pennsylvania Press, 1995); Elizabeth K. Rosen, Apocalyptic Transformation: Apocalypse and the Postmodern Imagination (Lanham: Lexington Books, 2008); Klaus R. Scherpe and Brent O. Peterson, "Dramatization and De-Dramatization of 'the End': The Apocalyptic Consciousness of Modernity and Post-Modernity," Cultural Critique 5 (1986): 95-129; Jacques Derrida, "Of an Apocalyptic Tone Recently Adopted in Philosophy," (trans. John P. Leavcy) Semeia 23 (1982): 66. For studies of apocalyptic approaches of climate change, see: Stefan Skrimshire (ed.), Future Ethics: Climate Change and Apocalyptic Imagination (London: Continuum, 2010); Jonas Anshelm and Martin Hultman, Discourses of Global Climate Change: Apocalyptic Framing and Political Antagonisms (London and New York: Routledge, 2015); Sergio Fava, Environmental Apocalypse in Science and Art: Designing Nightmares (London and New York: Routledge, 2013); Hicham-Stéphane Afeissa, La fin du monde et de l'humanité. Essai de généalogie du discours écologique (Paris: Presses Universaitiraires de France, 2014).

18 Calder Williams, Combined and Uneven Apocalypse, 156.

19 Christos Lynteris, "The Prophetic Faculty of Epidemic Photography: Chinese Wet Markets and the Imagination of the Next Pandemic," Visual Anthropology 29(2) Medicine, Photography and Anthropology (February 2016): 118-132.

20 Gershom Scholem, The Messianic Idea in Judaism: And Other Essays on Jewish Spirituality (New York: Schocken, 1995); Martin Munro, Tropical Apocalypse: Haiti and the Caribbean End Times (Charlottesville, VA: University of Virginia Press, 2015).

21 Danowski and Viveiros de Castro, The Ends of the World, 19.

22 Danowski and Viveiros de Castro, The Ends of the World, 21.

23 Danowski and Viveiros de Castro, The Ends of the World, 3.

24 Massimo Cacciari, Alessandro Carrera and Massimo Verdicchio, "Empire and Katechon: A Question of Political Theology (from Paul, 2 Thessalonians 2)," In Europe and Empire: On the Political Forms of Globalization, eds. Massimo Cacciari, Alessandro Carrera and Massimo Verdicchio (New York: Fordham University Press, 2016); For a recent study of the term, see: Paul Metger, Katechon: II Thess 2.1-12 im Horizont apokalyptischen Denkens (Berlin: Walter de Gruyter, 2005). 
25 Giorgio Agamben, The Mystery of Evil: Benedict XVI and the End of Days, translated by Adam Kotsko (Stanford, CA: Stanford University Press, 2017).

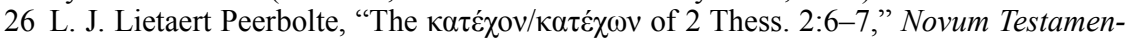
tum 39(2) (April 1997): 139.

27 The verb "katecho" (with the "ch" usually silenced) is still used in Crete to mean "to know" or "to understand."

28 Agamben, The Mystery of Evil; Cacciari, Carrera and Verdicchio, "Empire and Katechon"; Roberto Esposito, Immunitas: The Protection and Negation of Life (Cambridge and Malden: Polity Press, 2011). On Carl Schmitt's notion of the katechon, see: Julia Hell, "Katechon: Carl Schmitt's Imperial Theology and the Ruins of the Future," The Germanic Review: Literature, Culture, Theory 84(4) (2009): 283-326.

29 Again the usual English rendition of anomia in this work is "lawlessness", following Thomas Hobbes' ideologically driven 1629 translation.

30 The disease is no longer believed to have been caused by Yersinia pestis. On epidemic dramaturgy, see: John E. Atkinson, "Turning Crises into Drama: The Management of Epidemics in Classical Antiquity," Acta Classica 44 (2001): 35-42; Charles E. Rosenberg, "What Is an Epidemic? AIDS in Historical Perspective," Daedalus 118(2) Living with Aids (Spring 1989): 1-17.

31 The History of Thucydides, translated by S. T. Bloomfield (London: Longman, 1829), Vol. 1, 419. Though more recent translations of Thucydides' History of the Peloponnesian War are literally more accurate, I have chosen Bloomfield's translation where this is affectively closer to the original's intended poetics.

32 The History of Thucydides, 420.

33 The History of Thucydides, 421. For an elaboration of the significance of the epidemic corpse in Thucydides and its legacy, see: Christos Lynteris and Nicholas H. Evans, "Introduction: The Challenge of the Epidemic Corpse," In Histories of Post-Mortem Contagion: Infectious Corpses and Contested Burials, eds. Christos Lynteris and Nicholas H. Evans, pp. 1-25 (London: Palgrave Macmillan, 2018).

34 Robin Mitchell-Boyask, Plague and the Athenian Imagination: Drama, History, and the Cult of Asclepius (Cambridge: Cambridge University Press, 2007). On Thucydides and enargeia, see: Carlo Ginzburg, Threads and Traces: True False Fictive, translated by Anne C. Tedeschi (Berkeley: University of California Press, 2012).

35 The History of Thucydides, 422. Translation amended to reflect the correct meaning of "touto kai kalon kai khresimon".

36 Claudia Motti, "Le germe et le kratos: Reflexions sur la creation politique a Athenes," In Ce qui fait la Grèce: Tome 3, Thucydide, la force et le droit, Cornelius Castoriadis, pp. 13-26(Paris: Seuil, 2011), 19, my translation.

37 Clifford Orwin, "Stasis and Plague: Thucydides on the Dissolution of Society," The Journal of Politics 50(4) (November 1988): 831-847. For a recent discussion on "use" and the human body in the classical world, see: Giorgio Agamben, The Use of Bodies, translated by Adam Kotsko (Stanford, CA: Stanford University Press, 2016).

38 I borrow here from: Catherine Keller, Apocalypse Now and Then: A Feminist Guide to the End of the World (Minneapolis: Fortress Press, 1996), 87.

39 This notion, introduced by Danowski and Viveiros de Castro, will be discussed more extensively in Chapters 3-5, but it should already be clear that the term is not used in João Biehl's "exceptional" sense (2005).

40 In Keller, Apocalypse Now and Then, 62.

41 The Coming Plague was the title of Laurie Garrett's landmark bestseller (1994), whose publication in the mid-1990s, alongside Richard Preston's The Hot Zone (1994), marked the dawn of a prolific era of popular science books on the next pandemic.

42 Andrew Lakoff, Unprepared: Global Health in a Time of Emergency (Berkeley, CA: The University of California Press, 2017); Theresa MacPhail, "A Predictable Unpredictability: The 2009 H1N1 Pandemic and the Concept of 'Strategic Uncertainty' within Global Public Health,” Behemoth 3 (2010): 57-77; Carlo Caduff, The Pandemic 
Perhaps: Dramatic Events in a Public Culture of Danger (Berkeley, CA: The University of California Press, 2015); Limor Samimian Darash, "A Pre-Event Configuration for Biological Threats: Preparedness and the Constitution of Biosecurity Events," American Ethnologist 36(3) (2009): 478-491; Frédéric Keck, "Preparedness," Theorizing the Contemporary, Cultural Anthropology Website, September 30, 2016 https:// culanth.org/fieldsights/961-preparedness

43 Giorgio Agamben, The Time That Remains: A Commentary on the Letter to the Romans, translated by Patricia Dailey (Stanford, CA: Stanford University Press, 2005), 50.

44 Günther Anders, Les temps de la fin (Paris: L'Herne, 2007), 13, my translation.

45 Danowski and Viveiros de Castro, The Ends of the World, 26.

46 Ernesto de Martino, La fin du monde: Essai sur les apocalypses culturelles (Paris: Editions de l'Ecole des Hautes Etudes en Sciences Sociales, 2016).

47 Michaël Fœssel, “La 'fin du monde': une métaphore pour le présent?," Esprit 388(10) (October 2012): 35, my translation.

48 Jean Baudrillard, "The Anorexic Ruins," In Looking Back at the End of the World, eds. Dietmar Kamer and Christoph Wulf, translated by David Antal, pp. 29-45 (New York: Semiotext(e), 1989), 37. The idea was recently rehearsed once again by Sophie Fuggle (2014) in her essay about turning the apocalypse into a "non-event".

49 Jean-Pierre Dupuy, "Enlightened Doomsaying and the Concern for the Future," www. ritsumei.ac.jp/acd/re/k-rsc/lcs/kiyou/pdf_24-4/RitsIILCS_24.4pp.7-13DUPUY.pdf

50 On translating Anders' Zeitend and Endzeit, see: Danowski and Viveiros de Castro, The Ends of the World, 126, n.2.

51 Jason Dawsey, "After Hiroshima: Günther Anders and the History of Anti-Nuclear Critique," In Understanding the Imaginary War: Culture, Thought and Nuclear Conflict, 1945-90, eds. Matthew Grantand Benjamin Ziemann (Manchester: Manchester University Press, 2016), 149.

52 Ann L. Tsing, The Mushroom at the End of the World: On the Possibility of Life in Capitalist Ruins (Princeton: Princeton University Press, 2015).

53 Günther Anders, Die Antiquiertheit des Menschen Bd. I: Über die Seele im Zeitalter der zweiten industriellen Revolution (Munich: C.H. Beck, 2002). On recent discussions of Anders' notion of the Promethean gap, see: Alberto Toscano, "The Promethean Gap: Modernism, Machines, and the Obsolescence of Man," Modernism/Modernity 23(3) (September 2016): 593-609; Christopher John Müller, Prometheanism: Technology, Digital Culture and Human Obsolescence (Lanham: Rowman and Littlefield, 2016); Ulrike Ehgartner, Patrick Gould and Marc Hudson, "On the Obsolescence of Human Beings in Sustainable Development," Global Discourse, an Interdisciplinary Journal of Current Affairs and Applied Contemporary Thought 7(1) After Sustainability: What? (July 2017): 66-83.

54 For a boarder discussion on the "lack of imagination" in Anders's work, see: Paul van Dijk, Anthropology in the Age of Technology: The Philosophical Contribution of Günther Anders (Amsterdam: Brill, 2000).

55 Timothy Morton, Hyperobjects: Philosophy and Ecology after the End of the World(Minneapolis: University of Minnesota Press, 2013); Zygmunt Bauman, "A Natural History of Evil," S.I.M.O.N (22 March 2012) http://simon.vwi.ac.at/index.php/swl-reader/21-anatural-history-of-evil. For a similar approach, underlining how, in the case of climate change, "the scale of change is beyond our imagination", see: Ulrich Beck, "Emancipatory Catastrophism: What Does It Mean to Climate Change and Risk Society?," Current Sociology 63(1) (2015): 75.

56 This is carried over today to calls for "enlightened doomsaying" in light of existential risks; Jean-Pierre Dupuy, The Mark of the Sacred, translated by B. Debevoise (Stanford, CA: Stanford University Press, 2013). For discussion, see Conclusion.

57 In recent years, the figure of the Soviet Navy officer Vasili Alexandrovich Arkhipov has come to stand as a surrogate of this utopian hope, because of his role in not responding to depth charges against submarine $B-59$ by the US aircraft carrier $S S$ Randolf 
on October 27, 1962 (during the Cuban Missile Crisis) with a nuclear attack on the United States (which would have led to a nuclear holocaust). Jean-Pierre Dupuy, in his most recent book on nuclear catastrophe, writes: "Chance or Providence wanted for Arkhipov to be on board that day"; Jean-Pierre Dupuy, La guerre qui ne peur pas avoir lieu. Essai de métaphysique nucléaire (Paris: Desclée de Brouwer, 2018), 66, my translation.

58 De Martino, La fin du monde, 282, my translation.

59 On the notion of ex-humans, see: Danowski and Viveiros de Castro, The Ends of the World, 44.

60 Danowski and Viveiros de Castro, The Ends of the World, 94.

61 Joseph Masco, "The End of Ends," Anthropological Quarterly 85(4) (Fall 2012): 1107-1124. On nuclear ends and their difference to the next pandemic, see also Chapter 5. For a recent critical examination of nuclear existential risk and its apocalyptic inflections, see: Lisa Vox, Existenial Threats: American Apocalyptic Beliefs in the Technological Era (Philadelphia: The University of Pennsylvania Press, 2017).

62 Susan Scutti and Bijan Hosseini, "Mystery Illness Claims 12 Lives in Liberia," $C N N$, May 5, 2017, accessed May 10, 2017 http://edition.cnn.com/2017/05/01/health/liberiamystery-illness-who/

63 Centers for Disease Control and Prevention, "Remembering SARS: A Deadly Puzzle and the Efforts to Solve It," April 26, 2013, accessed May 10, 2017 www.cdc.gov/ about/history/sars/feature.htm

64 Carlo Caduff, "Great Anticipations," In The Anthropology of Epidemics, Ann H. Kelly, Frédéric Keck and Christos Lynteris, pp. 43-58 (London and New York: Routledge, 2019), 55, 47.

65 Dorothy H. Crawford, The Invisible Enemy: A Natural History of Viruses (Oxford: Oxford University Press, 2002), 6.

66 In fact, Susan Sontag (2009), whose Illness as Metaphor is a key reference of such works, had noted the similarity of AIDS/HIV's supposed trickster capacity with that of syphilis as developed in earlier centuries.

67 Jennifer Tucker, Nature Exposed: Photography as Eyewitness in Victorian Science (Baltimore: Johns Hopkins University Press, 2013).

68 Christos Lynteris, "A Suitable Soil: Plague's Breeding Grounds at the Dawn of the Third Pandemic," Medical History 61(30) (June 2017): 343-357; Christos Lynteris, "Pestis Minor: The History of a Contested Pathology," Bulletin of the History of Medicine, 93(1) 2019: 55-81.

69 Frank Kermode, The Sense of an Ending.

70 For a discussion of Jack London's pandemic vision, see: Michele Augusto Rova, Marta Benedetti and Giancarlo Cesana, "Pandemic Fear and Literature: Observations from Jack London's the Scarlet Plague," Emerging Infectious Diseases 20(10) (October 2014): 1753-1757.

71 Mark Harrison, "Pandemics," In The Routledge History of Disease, ed. M. Jackson, pp. 129-146 (London and New York: Routledge, 2017).

72 Harrison, "Pandemics," 135.

73 Agamben, The Mystery of Evil: Benedict XVI and the End of Days, 9.

74 Agamben, The Mystery of Evil: Benedict XVI and the End of Days, 10.

75 Scherpe and Peterson, "Dramatization and De-dramatization of "the End". 


\section{Zoonotic transformations}

From afar the cover of the New Scientist, May 9-15, 2015, looks like a fractal psychedelic pattern, but the title makes you focus: "The New Plague: We're one mutation away from the end of the world as we know it" (Fig. 2.1). ${ }^{1}$ Mounted on a bright yellow background, the "trippy" pattern is in fact a composite of hundreds of virus visualizations into a single, threatening meta-virus. The center of the image is dominated by what looks like five inter-imposed flu-like viruses, whose interlaying creates a three-dimensional illusion. A spiky "biohazard" symbol seems to be emerging out of these blue-colored viruses and at the same time to be holding them together as a symbolic substructure. First developed in 1966 by Charles Baldwin, this symbol, which was originally designed for narrow use, has come (to the expressed dismay of its creator) to be employed extensively to convey pandemic existential risk. ${ }^{2}$

In the New Scientist cover, the biohazard sign is used to create a viral vortex or, if we let our imagination run wild for a second, to simulate the dented pharynx of a viral beast. The ridge of the influenza/biohazard composite is crowned by what looks like a quartet of sinisterly entangled Ebola viruses. Possessing one of the most publically recognizable virological contours, the form of the "wormy" Ebola virus has in the past 20 years been extensively used to convey "disease emergence". ${ }^{3}$ The image, as Kirsten Ostherr has noted, has been deployed by pandemic films like Wolfgang Petersen's (1995) Outbreak for the iconic way in which, through their phallomorphic manipulation, Ebola-looking viruses are able to evoke fear of "flesh-eating" diseases. ${ }^{4}$ In the particular case, the Ebolaesque viruses are entangled in such a way as to produce a symmetrical image that iconographically hankers back to one of the most ancient tropes of depicting bestial enemies of humanity: the so-called bicorporate. Widespread in seventh-century BCE Luristani and Assyrian art, the motif was later adopted in Greece; it represents two animal bodies with a common joined-up head. While the bodies are set in profile, the beast's face is always turned toward its viewer like an apotropaic mask. ${ }^{5}$ In the case of the New Scientist cover image, each bicorporate's tentacles expand like serpentine Gorgonean hair, so as to meet at their ends the "tentacles" of the other viral beasts, each of which, all in all four in number, occupies one of the cardinal points of the horizon. ${ }^{6}$ Five more concentric cycles of fractally rendered viruses ensue, until we reach the outmost ridge of the "end of the world" 


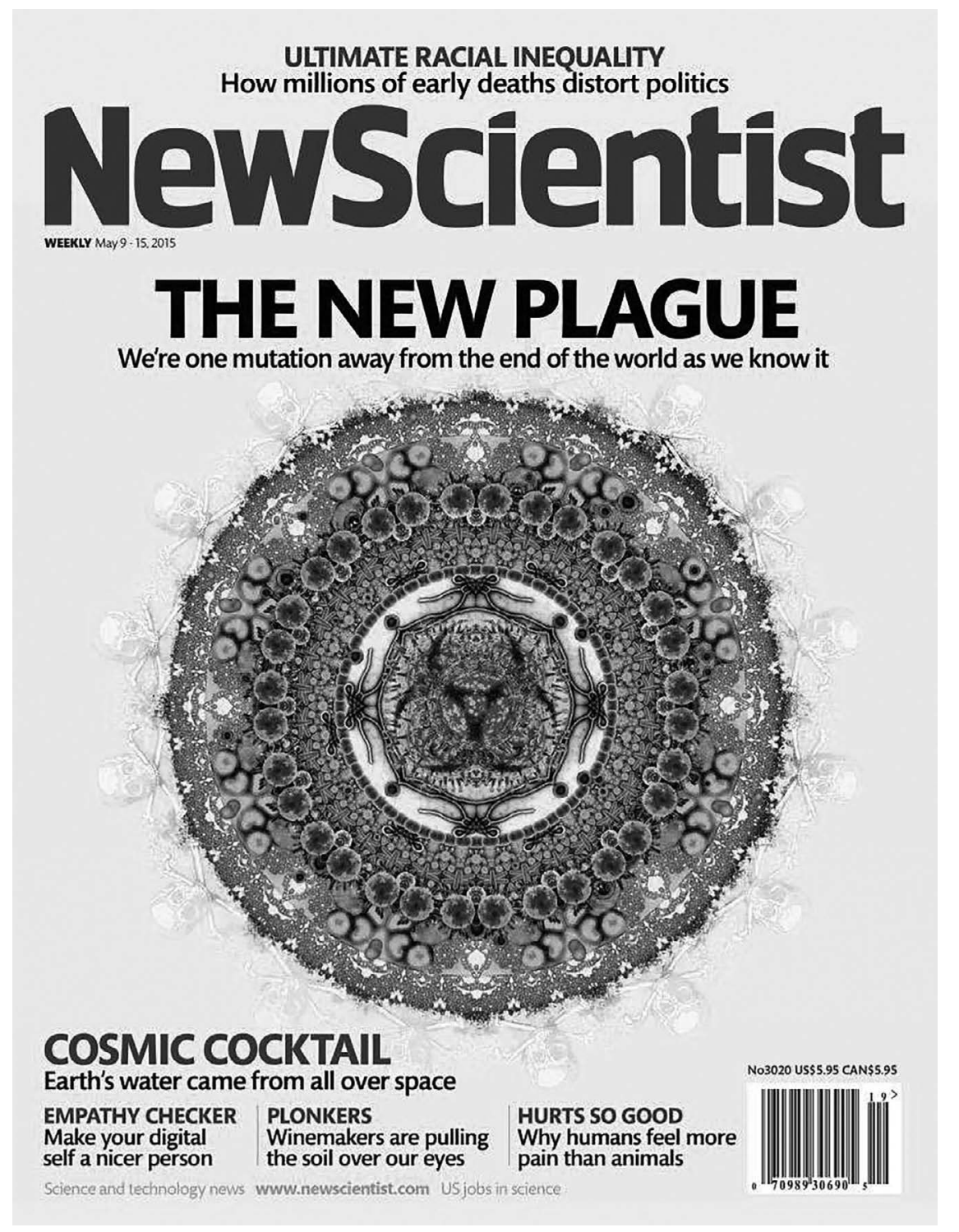

Figure 2.1 "The New Plague: We're one mutation from the end of the world as we know it" (New Scientist cover, May 9, 2015).

Source: New Scientist 
meta-virus. There, in a surprising Gothic turn, the illustrators have positioned, in lieu of protein receptors, a circle of large human skulls and crossed bones, an image perhaps meant to connote both the human-targeted deadliness of the metavirus and its "pirate" nature. Connoting both an elusive, contraband force and "the common enemy of all", the depicted virus's piratical character consists not only in the way humans approach viruses - as faithless enemies that need to be faced faithlessly - but also in the way in which viruses in turn challenge us by putting our humanity to the test. ${ }^{7}$ For, following the etymology of the Greek peirao (to test or experiment, to attack, to try one's luck, to put someone's integrity or trustworthiness to the proof), a virus "is, quite literally, an entity defined by risk". 8

Through the interrelation of its visual various components, the New Scientist cover carries through a pandemic forecasting: of the end of the world in the hands, or rather the spikes, of a killer virus. It is a warning sign for the extinction of the human species as a result of a newly emerged pathogen to which we will be globally and collectively nonimmune. Viruses are the uncontested agents of the next pandemic and human extinction. As anthropologists have extensively demonstrated, their ontological and cosmological status plays a key role in current biopolitical regimes of preparedness. ${ }^{9}$ The opening lines of the fictional CDC epidemiologist Ephraim "Eph" Goodweather, in the popular TV adaptation of The Strain (2014), are revealing of the exceptionalism involved in this viral fantasy:

A virus exists only to find a carrier and reproduce, that's all it does and it does it quickly; it has no political views, it has no religious beliefs, it has no cultural hang-ups, and it has no respect for a badge; it has no concept of time or geography, it may as well be the Middle Ages except for the convenience of hitching a ride on a metal tube riding from meal to meal to meal. ${ }^{10}$

Yet the agents of the end should not be confused with its origins, a category with a distinct, and arguably more pervasive, mythic potential. For, as Walter Benjamin has argued, "the origin stands in the flux of becoming as a vortex and rips into its rhythm the material of emergence". ${ }^{11}$ Giorgio Agamben has urged us to take this identification of origin with a vortex seriously. And this is indeed what becomes necessary when we are confronted with the panoply of originary mythemes punctuating the cosmology of disease emergence: spillovers, species jumps, and viral chatters. For how else can we account for the identification of origination and becoming that is prevalent in the pandemic imaginary? "Like the whirlpool in the river's flow, the origin is simultaneous with the becoming of phenomena, from which it derives its matter but in which it dwells in a somewhat autonomous and stationary way". 12

What are then the imaginary origins of the next pandemic? This is easily answered on a first level: "Everything comes from somewhere, and strange new infectious diseases, emerging abruptly among humans, come mostly from nonhuman animals". ${ }^{13}$ Yet, when approached more carefully, this question proves to be far more productive in debates and aporias. Is the next pandemic foreseen to originate in nonhuman animals per se or, more specifically, in human-animal contact? 
Or is it "our dysfunctional relationship with the animal kingdom" that is the true origin of human extinction? ${ }^{14}$ Or indeed, "nature" itself? In this chapter, I will argue that in positioning the origins of humanity's demise in and between these categories, what is in fact instituted is the forecasted loss of humanity's mastery over human/nonhuman relations. In particular, I will explore how the imaginary institution of existential risk is predicated upon a shift in epidemiological reasoning about zoonosis (animal to human infection) - a shift, I will argue, that entails an abandonment of a vision of infectious diseases as essentially belonging and reproduced in the animal realm and only accidentally or temporarily affecting humans. Deploying a comparison between emergence and pre-emergence modes of visualization of zoonosis (photography and diagrams), I will show that under the new emergence-led paradigm, by contrast, humans and nonhuman animals are configured as inextricably entangled, with nothing being able to block or avert zoonotic infection. The visual examination of this transformation offers us a unique analytical opportunity, not simply for making intelligible an epistemological discontinuity or shift but also for taking a crucial step toward grasping an epistemic and at the same time aesthetic transformation that renders human-animal distinction ontologically meaningless but biopolitically actionable.

To trace the epistemic, political and aesthetic transformation of ideas about zoonotic infection would require a lengthy and complex genealogy. No work has so far undertaken to write this history, which would need to account for the crossed epistemic trajectories of Kochean and Pasteurian schools of bacteriology (in their "internal" diversity), British tropical medicine, the Soviet doctrine of natural nidality and its adherents and opponents in the Eastern Block, Chinese epidemiology as developed under shifting state-socialist regimes, and diverse approaches developed in South America. In the absence of this, I will here rely on connecting my own research in two fields from across the "emergence" divide (turn of the nineteenth-century bubonic plague and turn of the twentieth-century SARS) so as to attempt a sketch of the transformation that has been taking place since the early 1990s. We should, however, keep in mind that while today globalization has come to integrate to an unprecedented degree not only the spread of infectious diseases but also epidemiological reasoning about them, in the era preceding the end of the Cold War, and even more so during the decades preceding the formation of the WHO, the global landscape of epidemiological reasoning was diverse and often characterized by antagonistic epistemic visions. That said, it is worth risking here a sketch of the formation of the notion of zoonosis before "the emergence of emergence", at least as a heuristic device pointing not so much to epistemic, political, or aesthetic micro-histories on the ground but to the broader ontological and biopolitical framework constituted by them. ${ }^{15}$

\section{Zoonosis before emergence}

The first scientific observations of animal-to-human infection revolved around rabies and its spread from dogs to humans. However, the study of animals as the origins of human disease, and of the mode of transmission between the two, was 
first systematically developed in the context of a global urgency that shook the world at the end of the nineteenth century: the third plague pandemic. ${ }^{16}$ Marking a resurgence of bubonic plague and its spread across the globe, between 1894 and 1959 the pandemic struck at major cities and ports in every inhabited continent. ${ }^{17}$ If the total number of dead resulting from the third plague pandemic (c. 12 million) was not as impressive as the one believed to have resulted from the first two pandemics of the disease, plague still played a catalytic role in a range of social, political, and epistemic fields: the development of bacteriology and its entanglement with sanitary reform, the emergence of epidemic photography, the transformation of housing regulations and urban plans, the development of mechanized maritime fumigation, the renegotiation of international quarantine regulations, the interaction of colonial powers and colonized societies, local-national dynamics in several areas of the globe, the consolidation of modern medicine in areas where it was hitherto absent or of little importance, and the overall development of modern biopolitical visions and programs under the rubric of what Ruth Rogaski has termed "hygienic modernity". ${ }^{18}$ Perhaps the least understood and most understudied transformation brought about by this pandemic concerned animal-human relations.

Contrary to popular perceptions, before 1894 rats had not been shown or believed to be the carriers or spreaders of bubonic plague. ${ }^{19}$ Instead, as Neil Pemberton notes, as late as the $1850 \mathrm{~s}$,

rather than being correlated with plague, the sewer rat's appetite for putrefying matter saved human inhabitants from "periodical plagues", which James Rodwell [author of the 1858 popular treatise, The rat: its history \& destructive character] insisted were the "result of deadly gases arising out of the putrefaction of animal and vegetable matter". ${ }^{20}$

The inaugural outbreak of the third plague pandemic in Hong Kong in 1894 is associated with the discovery of the pathogenic agent of the disease by Alexandre Yersin. ${ }^{21}$ At the same time as identifying the plague bacillus, the young Pasteurian also speculated about the possible role of the rat in the epidemic on the basis of local narratives from areas previously stricken by the disease in the Chinese hinterland. ${ }^{22}$ It would take another three years for another Pasteurian, Paul-Louis Simond, to link the rat and its flea (Xenopsylla cheopis) directly to the spread of the disease, this time in British India. ${ }^{23}$ Rather than being hailed as a turning point by the medical and scientific community, however, this breakthrough was cautiously received. Indeed, it took another eight years before the rat and flea compound would become universally recognized as the prime spreader of plague among humans. The rat would thus begin its inglorious career as an epidemic villain. ${ }^{24}$

What started at the turn of the nineteenth century as the cautious deratization of cargo ships would soon give way to a global war against the rat. ${ }^{25}$ Mass campaigns against the animal rapidly spread across the globe, involving "rat-proofing" (also known as "building out the rat") and rat eradication through poison, pathogens 
(famously, the Danysz virus), traps, dogs, cats, and other means of destruction. ${ }^{26}$ The campaigns assumed different guises in different contexts, becoming entangled with racial, national, colonial, vocational, geopolitical, and class narratives and agendas. The net effect was that by the mid-1920s the rat had been transformed from a mere nuisance to a charismatic epidemiological foe. A characteristic view of the time is expressed by R. H. Creel, Assistant Surgeon of the US Public Health Service, who, writing in 1913, would begin his review of the rat as "a sanitary menace and an economic burden" by stating that "of all the parasites that have their being in and around the habitation of man the rat has less to justify its existence than any other". ${ }^{27}$ Seen as "devoid of any redeeming traits", the rat was condemned as "a greater pest" even than the fly, "because of its depredations and its possibilities for harm in the transmission and perpetuation of bubonic plague in a community". ${ }^{28}$ The doctrine developed - not only in the USA but also across the globe - was thus summarized in the slogan "No rats, No plague":

PLAGUE, RAT, FLEA, MAN, PLAGUE, RAT, FLEA, AND MAN AGAIN, so the cycle runs unless interrupted. KILL THE RAT AND THE FLEA and there will be no plague. ${ }^{29}$

We need to be careful here: for this transformation did not entail the rat's configuration into the origin (or indeed agent) of human extinction. The narratives, questions, and directives woven around the particular animal concerned the health of entire nations or "races", the vital resources and infrastructures of cities, and the economy of empires but not the survival of humans as a species. At the same time, if by the mid-1920s the rat had been rendered in public consciousness plague's indisputable protagonist and a prime suspect in terms of the transmission of other diseases from animals to humans, it was not the sole object of research that led to the consolidation of the notion of zoonosis. ${ }^{30}$ Also important to the latter was the study of what are known as sylvatic or wild hosts of plague such as marmots, prairie dogs, gerbils, and other such rodents (203 mammals are known to carry the disease today).

Catalyzed by the devastating Manchurian plague epidemic of 1910-1911 but in fact predating it by 16 years, research on sylvatic plague attracted the attention of scientists in as diverse settings as South Africa, Argentina, Iran, Russia, Kenya, China, and the USA. These autonomous spheres of research, and what following Warwick Anderson we may call the "biocolonial exchange" between them, provided crucial conceptual and methodological germs, leading to the consolidation of the notion of zoonosis by the $1940 \mathrm{~s} .{ }^{31}$ Briefly, what these appear to have had in common were the following:

1 An understanding that plague originates and is preserved not among rat populations, which perish under the bane of the disease, but among wild rodent reservoirs who manifest a greater degree of resistance to it.

2 The hypothesis that the disease is actually maintained not simply in a given host population (say Siberian marmots or great gerbils) but in the networks 
and interrelations between them under specific environmental conditions, forming what came to be known as a "disease ecology".

3 An understanding that human infection, if no less devastating, was episodic, with humans being a "dead end" of the particular disease.

Historians and anthropologists have recently began to unpick the complex epistemic and political trajectories of these two sets of plague-related assemblages: on the one hand, colonial and metropolitan medical problematizations of the rat and, on the other hand, the formation of epidemiological reasoning regarding sylvatic aspects of plague. ${ }^{32}$ This offers us, for the first time, a rich reading of latenineteenth-century and early-twentieth-century understandings of animal-human infection, which goes beyond the blindfolds of lab-centrism. ${ }^{33}$ And yet, in order to understand the emergence of zoonosis as an epidemiological framework and, at the same time, as a biopolitical and ontological prism of human-animal relations by the $1940 \mathrm{~s}$, what we need is to grasp the interrelation between these two very different but also institutionally interlinked trajectories of understanding plague as a zoonotic disease. For what linked the study of rat-related plague and the study of sylvatic plague was not simply the methods used to know the disease (bacteriology, medical geography, statistics, ethnography, etc.) but more crucially a common vision of animals in relation to humans and their health.

First, this was both a modern and an imperial vision. Modern, in the sense that it carried with it an agenda related to the goal of "hygienic modernity", not in the strict China- and Japan-bound meaning of the term (weisheng), as explored by Rogaski, but in a broader sense: as an imperative that construed hygienic spaces and lifestyles as an absolute condition and proof of the modernization of societies, nations, and empires. At the same time, this vision was imperial, not simply because it unfolded in the context of existing empires (Russian/Soviet, British, French, American) nor, more specifically, because it included animals as "nonhuman subalterns": "victims of imperial violence; [ . . ] products of imperial regimes of subjectification; and [. . . ] usually marginalized in imperial historiography". ${ }^{4}$ But rather, because imperial projects increasingly depended on the scientific knowledge and management of rats, marmots, and other plague-carrying rodents and, more specifically, on configuring their pathogenic potential into a scientifically knowable and actionable category.

Second, this was a vision that involved the inclusion of animals into complex experimental systems. These ranged from an international network of chemical experiments with fumigants (sulfuric, carbon-based, or other) in an effort to discover and develop the optimal mechanized system for ridding cargo boats from rats, fleas, and plague bacteria without harming the fumigated merchandize and to identify the spatial range of rat movement in the human-built environment by capturing, marking, releasing, and recapturing rats in Cairo, to surreal-looking experiments conducted in Manchuria by teams of Chinese and European scientists trying to decipher whether marmots could spread plague to one another in an airborne manner. ${ }^{35}$ Whether lab, field, or, indeed, boat based, rather than simply involving methodological innovation, this network of zoonosis-related 
experiments instituted rodents as paradigmatic experimental subjects - a trend that would have a major impact on biological and behavioral sciences as a whole.

Most importantly, however, the epidemiological vision bridging rat and sylvatic plague studies was one that instituted an integrated view on disease origins. This was not, at the time at least, related to the evolutionary origins of plague. Instead, through their slow integration, studies of rats and studies of sylvatic hosts led to a unified field of vision regarding "where plague comes from", what is its "natural milieu", and how from there it spreads to humans. Whereas, in reality, the disease ecology of plague involves complex systems of pathogen maintenance and transmission, as a result of both its own tendency toward a conceptual economy and public health demands for simple narratives and solutions, by the 1930s epidemiological reasoning had coagulated around a basic scheme that, in terms of a visual heuristic device, took the form of the "zoonotic cycles" diagram.

Quickly becoming a prevalent diagram of animal-human infection, zoonotic cycles drew out the way in which a given pathogen circulates among nonhuman animal species, often with the help of insects, as well as the way in which it spreads to humans. ${ }^{36}$ More importantly, however, this visual device functioned as an epidemiological Rosetta Stone, forging universally recognizable linkages between animals and humans. Rather than simply representing a fact, it became a tool for rendering infection intelligible as a relation that spans the species divide an epistemic thing in Hans-Jörg Rheinberger's sense of the term, that forged a dynamic yet unstable common ground between humans and nonhuman animals. ${ }^{37}$

Characteristically, an early form of these diagrams first appeared in the work of a key proponent of disease ecology approaches of zoonosis, the Swiss-born professor of bacteriology at Berkeley, Karl F. Meyer. Developed in the context of the Sylvatic Plague Committee in the 1930s and in critical dialogue with Charles Elton's population dynamics, Meyer's work described plague ecology in terms of "periodic-cyclic fluctuations", pertaining to "the interrelations between the plague bacillus, the rodent and flea population and the factors of the environment". ${ }^{38}$ While earlier visualizations employed mostly linear, one-way "story boards" that showed how from a rat, positioned on the top of the list-like schema, plague spread through a flea to humans below, Meyer introduced a more circular visual model of infection (Fig. 2.2) ${ }^{39}$ Here plague could be seen to be transmitted among and between different rodent species via fleas, whence it attacks humans. ${ }^{40}$ Further simplified and schematized in the aftermath of the Second World War, plague diagrams would henceforth comprise cyclical models of inter-rodent pathogen transmission. In fact, these diagrams would increasingly begin to resemble feedback loops, in accordance with the growing cybernetic paradigm at the time. ${ }^{41}$

I have drawn an extensive anthropological critique of these diagrams and their applications on the ethnographic ground elsewhere. ${ }^{42}$ What I want to do here is return to them so as to use them as windows into pre-emergence notions of zoonosis and the ways in which these configured human-animal relations. What do we see in these visual devices, whether these are applied to plague or to another zoonotic pathogen? These diagrams are usually composed of three main components: (a) schematic host and vector figures, usually humans, nonhuman animals, and 


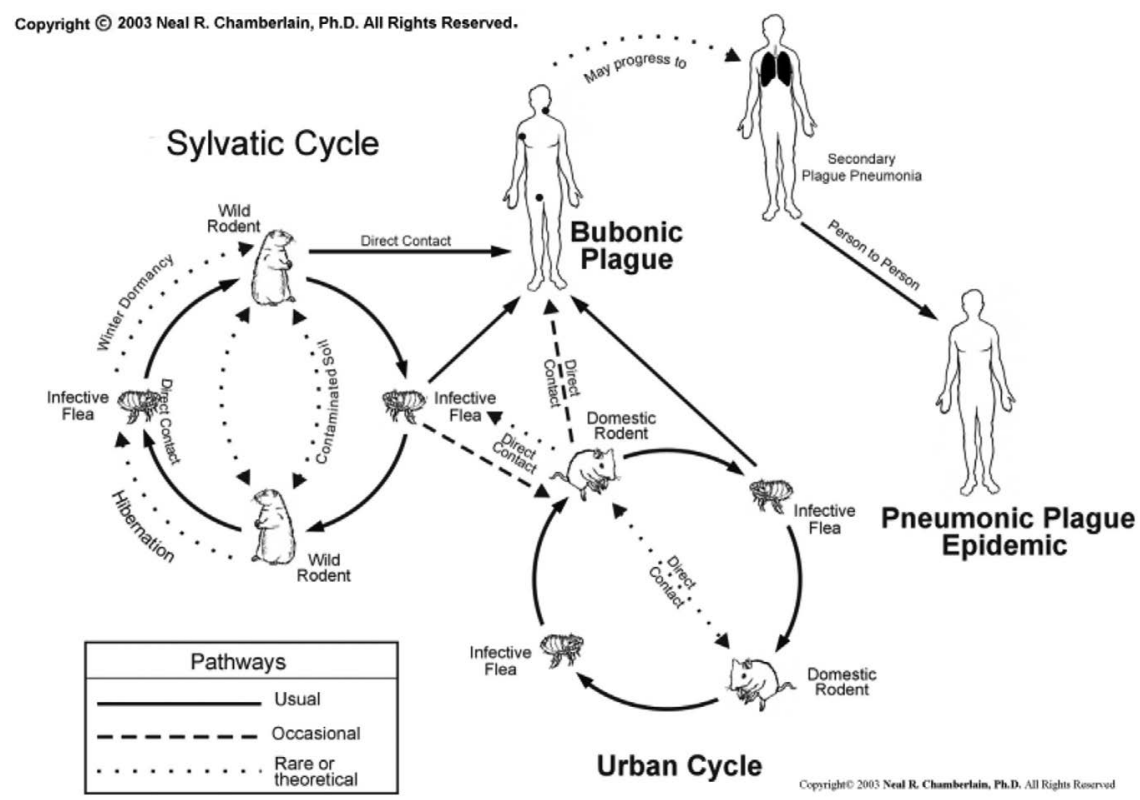

Figure 2.2 An example of zoonotic cycles applied to plague in contemporary studies.

Source: Courtesy of Neal R. Chamberlain, $\mathrm{PhD}$

insects; (b) pathway lines or arrows demarcating pathogen transmission; (c) the blank surface on which these are inscribed. In order to understand the operational field of these devices, we need to explore how the diagrammatic regime emerging out of the interrelation between these components is based on hierarchical levels of integration, which join these up in a unified visual field. ${ }^{43}$

The key component in this diagrammatic economy is, in every case, the human figure. Functioning as the end point of infection, it usually assumes a generic, formalized contour, inhabiting the right top corner of zoonotic cycle diagrams. This position guides our left-to-right text-reading gaze toward the telos or "deadend" of human infection. ${ }^{44}$ Moreover, the relation of the cycling arrows between animals and fleas and the arrows breaking loose from this cycle and ending up at the human target function in a powerful symbolic way suggest affliction, much like the classical arrows of Apollo Smyntheus, the plague bringer, or the arrows of pestilence piercing the body of St. Sebastian in Renaissance depictions of plague..$^{45}$ These schematic markers operate not simply as connecting lines between two or more figures but as etiological trajectories and, at the same time, as visual metaphors of affliction and contamination long-entrenched in European representations of pestilence.

At the same time, investing in norms of top-down, list-associated reading gaze, this zoonotic diagram sets humans quite apart from the chain of infection between 
"natural" hosts and vectors of the disease. It is indeed common for the human figure to inhabit the top-right quarter of the diagram all by itself, while other hosts or vectors populate the two left-hand-side quarters of the image. Seen from this perspective, humans appear to belong to a separate taxonomic stratum of the natural world, a nature outside nature. Hence, we can say that, in these diagrams, infection is configured as, at one and the same time, a vital field of commensality and a "zone of indifference" or "missing link" between animals and humans. ${ }^{46}$ Moreover, in these diagrams, nonhuman animals almost always appear in pairs or multitudes connected by looping arrows, a visual device that does not simply convey that the pathogen circulates among given animal hosts but that these hosts reproduce it in a feedback and largely homeostatic manner until, for some reason, it reaches a threshold or tipping point and spreads to humans. It is therefore important to examine how these diagrams function not only as "a way of dividing up space, classifying regions of space" but also as a way of dividing up time and, in turn, different species or life-forms in terms of time. ${ }^{47}$

In a wide range of applied incarnations of the zoonotic cycles diagram, the spatiotemporal threshold leading to human infection is depicted as conditioned upon an event known as the epizootic (Fig. 2.3). If zoonosis signifies the moment where animal to human infection is actualized, the adjective "enzootic" refers to a process during which a pathogen circulates within a given animal population (usually the reservoir host) without any major mortality observed. "Epizootic" in turn refers to phenomena of kill-offs or massive mortality events during which large numbers of the host population become infected and die. In this way, the various agents of plague and their linkages are mapped onto three pathogenic fields, whose dynamic interpositioning plays a vital role in the hierarchical integration of the said agents into the visual field of zoonosis, as a pathogenic process fundamentally mediated by an epizootic event. This visualization of zoonosis fosters an image of wild rodents and their fleas as the ultimate source of plague belonging to, as it were, "deep nature", far removed from humans, and of epizootics as the mediating, evental mechanism leading to human infection. In this way, it creates a two-layered remoteness of humanity from what is imagined as the natural and original abode of the disease - its reservoir. And, at the same time, this visualization configures infection as a process through which a temporal sequence of quantitative changes (enzootic to epizootic) within the realm of nonhuman animals leads to a dialectical, and lethal, qualitative transformation: animal to human infection.

This is a condition that renders human infection predictable and, as a result, preventable by means of a blockage of the mediating agent or process of infection. It is thus part of a sanitary-utopian vision well entrenched in the reassuring certainties of what we may call high-modern epidemiology. Human infection will occur (by means of the epizootic as a quantitative change leading to zoonosis as a qualitative one) unless the final, pestilential arrow leading from animal cycles to humans is severed through the insertion of some sort of "noise": DDT flea eradication or rat-proofing of domestic and commercial infrastructures in the case of plague. The threshold visualized by this diagram is hence rendered a knowable and preventable incident - a process that can and must be mastered by humanity. 


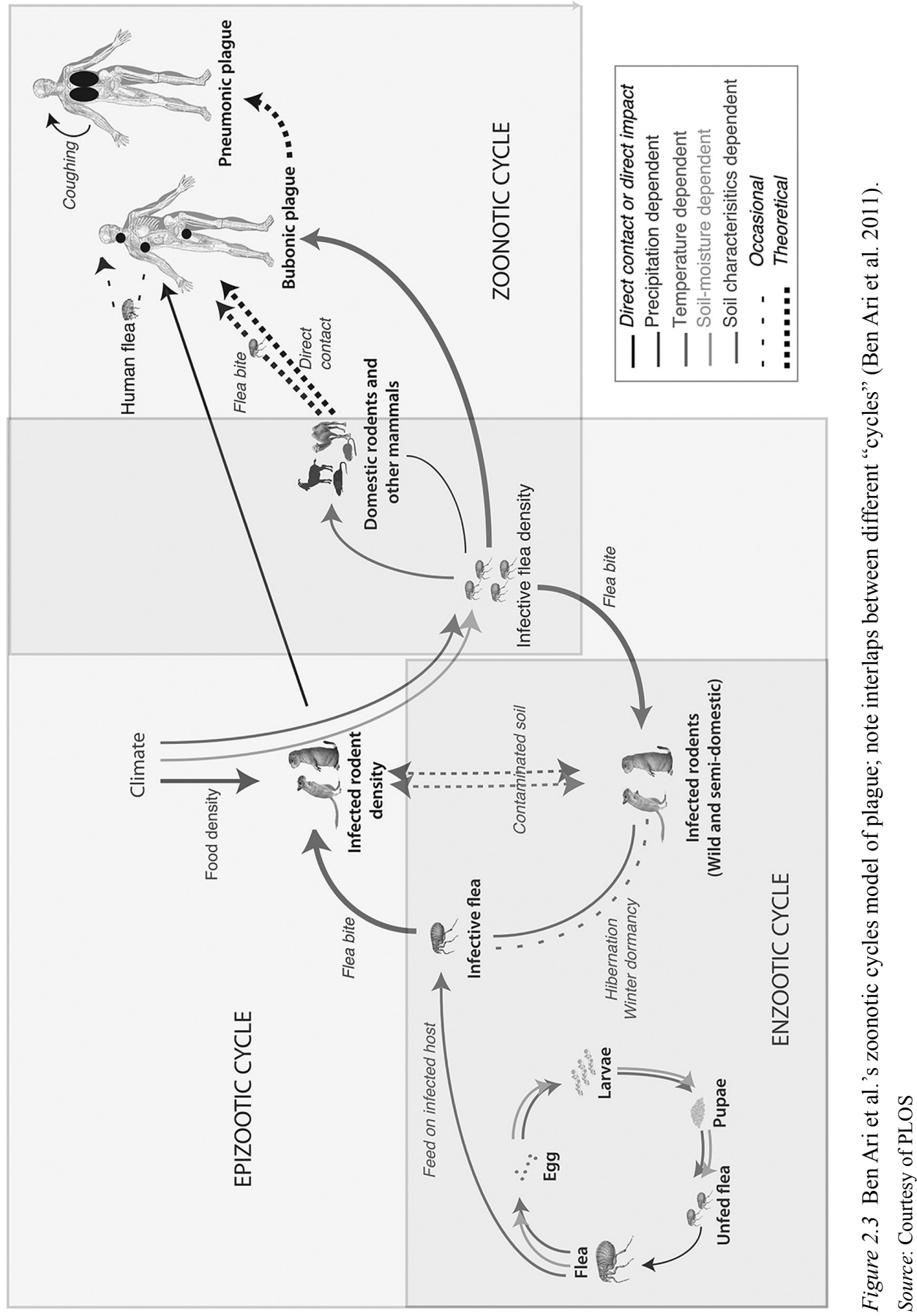


This is a vision of human infection from nonhuman animal sources as an extrasocietal exchange, an invasive form of communication from nature into culture. Infection is represented not as a historical and relational potential of the irreducibly interspecies fabric of social, political, and economic life but, instead, as a contraband import or pollution from a separate realm of existence. This zoonotic model thus ontologically encompasses a distinctly naturalist vision of humananimal relations as predicated upon "a discontinuity of interiorities and a continuity of physicalities" (i.e., the simultaneous commonality of life and difference of being). ${ }^{48}$ And, at the same time, it articulates these relations biopolitically on the grounds of exception: as relations that "necessarily function by means of an exclusion (which is also always already a capturing)" of humanity into the animal realm and "an inclusion (which is also always already an exclusion)" of infection into the realm of humanity. ${ }^{49}$ Crucially, the dynamic interrelation of these ontological and biopolitical operations unfolds on the terrain of the "chain of infection". For the sanitary-utopian aspiration to liberate humanity of zoonotic disease is based on no less than a vision of universal "breaking of chains", a separation, and at the same time unshackling, of humans from animals through the application of DDT, rat-proofing, and so forth - methods that would isolate the pathogen in its "natural reservoirs", which collectively define the animal realm. In this way, whereas separation from animals is seen as a sufficient means of protection of humans from zoonotic disease, animals themselves are defined as ultimately hygienically unredeemable - they are, in other words, rendered indistinct from disease. Hence, the naturalist ontology, which in the heuristic model of Philippe Descola defines humans and animals as unified under the rubric of nature, is unsettled by a radical biopolitical divide that sees disease as a mode of being that is only inherently proper to nonhuman animals and only tentatively, or as sanitary utopians would have it, temporarily, part of the human species.

We may then say that zoonotic cycles point beyond a visual device to what, following Steven Hinchcliffe, Nick Bingham, John Allen, and Simon Carter, we may call a particular "Disease Diagram". Hinchcliffe et al. employ this term with the specifically Deleuzean intention of referring not to visual diagrammatic forms but to "the discursive and non-discursive 'mappings' into thought and practice that give shape to an issue or problem". ${ }^{50}$ If this is indeed a useful notion, we must nonetheless resist adopting a formalization of historical disease perceptions and anti-epidemic measures into what Eugene Thacker has termed Michel Foucault's three diagrams of disease: leprosy, plague, and smallpox. ${ }^{51}$ Whether or not this does justice to Foucault's own work, this tripartite separation relies on a misleading historicization of epidemic control policies that can no longer be sustained in light of the rich historical corpus on the subject made available in recent decades. Instead of such broad-stroke macro-historical typologies, what the close examination of epidemiological reasoning carried over by zoonotic cycles allows us to reach is a more modest but also more historically accurate diagnosis of the anthropological pivot of the Disease Diagram of zoonosis as this became prevalent by the 1940s. I would like to argue that at the heart of every Disease Diagram lie, as its organizing principle, not simply ideas about 
animals, space, or pathogens but, most importantly, ideas about humanity's relation to the nonhuman world.

The anthropological pivot of the first age of zoonotic reasoning, which we have briefly examined above, was a belief that human relations with the nonhuman realm are fundamentally underlined by a project of mastery; a mastery, as Walter Benjamin noted, not of "nature" itself but of human relations with the nonhuman. ${ }^{52}$ In the original Disease Diagram of zoonosis, this mastery was configured as a project that could be realized by means of distancing and separation; in other words, through a problematization of and intervention on human/nonhuman relations in terms of "contact".

Here then we have an articulation of human/nonhuman relations that is spatially organized. And by the 1940s this organization was no longer simply ethical, in the sense of humans distancing themselves from their own "animal" nature by means of disciplinary regimes of "de-animalization" involved in the cultural regulation of eating, reproduction, and so forth, as devised in the preceding century by the triumphant bourgeoisie. Instead, it was principally material, insofar as the human project was seen as dependent on the physical separation and distancing from nonhuman animals. Human mastery over human/nonhuman relations was thus envisioned as a mastery over physical contact (direct or indirect, via feces, blood, or other secretions) and its spaces: homes, warehouses, or sheds that needed rat-proofing, merchant vessels and hospitals requiring fumigation, or agricultural fields that needed DDT dusting.

As Victor Narat et al. have recently noted, today's emergence paradigm also relies on notions of contact and, indeed, as will be explored shortly, on their categorical vagueness. ${ }^{53}$ Yet, at the same time, what has allowed the consolidation of a pandemic imaginary as regards human extinction is a move away from the ontological, biopolitical, epistemic, and aesthetic complex of the original Disease Diagram of zoonosis. The transformative pivot of this move lies with the form of human mastery, or lack thereof, that is entailed by the Diagram of emergence.

\section{The diagram of emergence}

The proliferation of the notion of emergence across the arts, humanities, and sciences in recent decades has relied on long-established studies of the processes through which large-scale patterns or forms result from the interaction and selforganization of smaller-scale, less complex components (for example, snowflake fractal patterns or termite mounds). More recently, interest in self-organized, spontaneous order and complex interconnectivity has led to emergence-focused perspectives that place emphasis on the entanglement of different scales of cause and consequence. The development and application of emergence-led frameworks has been particularly pronounced in the spheres of global health, urban development, and technology. If in each of these areas emergence has come to encompass a distinct set of principles, on the ground its application has led to overarching and interlinked regimes of anticipation. No longer simply focusing on "change", emergence-based approaches set ontogeny at the center of the 
prospects and challenges facing our world. At the same time, driven by a complexity and dynamic systems approach, the focus on emergence marks a significant departure by fostering a uniquely integrated framework for understanding the advent of new forms and patterns. In this way, emergence in any one sphere, for example, urban development, becomes the condition of possibility for emergence in any other sphere: new viruses, technologies and economies, or even new forms of democratic participation or extremism.

Nicholas King has traced the "emergence of "emergence" in the realm of Global Health to the 1989 conference "Emerging Viruses" chaired by Stephen S. Morse who differentiated between evolutionarily new viruses and "existing viruses transferred unchanged or with slight variations to the human population". ${ }^{54}$ King has stressed that the rhetorical power of this distinction lies with the contention that while true evolutionary changes cannot be predicted, the latter form of variation and interspecies transfer can. Moreover, this is a process seen as linked to and accelerated by globalization. King further traces the institutionalization of emergence to the report Emerging Infections: Microbial Threats to Health in the United States (1992), authored by a National Academy of Science's Institute of Medicine committee co-chaired by Morse and Joshua Lederberg. The report, King claims, was a landmark in reversing the draining of funds for research in infectious diseases, directly "targeting policymakers and framing its arguments in terms of American public health and national security". ${ }^{55}$ It may thus be considered the blueprint of what King calls an "emerging diseases worldview", as a flexible consensus that provides public narrative and policy "with a consistent, self-contained ontology of epidemic disease: its causes and consequences, its patterns and prospects, the constellation of risks that it presents, and the most appropriate methods of preventing and managing those risks" ${ }^{56}$ As a result of the media advocacy program of what King calls the emerging disease campaign, in the early 1990s journalists became quickly interested in the hitherto scientifically arcane notion of emergence, which became "a powerful scalar resource for characterizing individual outbreaks as incidents of global significance". ${ }^{57}$ In this respect, the introduction of emergence into popular discourse may be said, if not to have really invented epidemiological scalar projection, then certainly to have brought it up to date in the context of Global Health imperatives so as to configure limited, local outbreaks of infectious disease as precursors of global pandemics.

As several critics have pointed out, the inaugural text of this new form of outbreak narrative was Richard Preston's New Yorker article "Crisis in the Hot Zone", which warned against the emergence of a pathogen that "could wipe out our species" ${ }^{58}$ Over the next five years, this idea of the next pandemic as a singular event of species extinction was rapidly popularized and disseminated through the international bestselling writings of Preston and Laurie Garrett. In her 1994 book The Coming Plague, Garrett presented the next pandemic as a result of shifting cultural practices, geopolitical relations, and economic regimes, which she described as resulting in a perilous world out of balance. ${ }^{59}$ In the same year, Preston in his book The Hot Zone forecasted the next pandemic as a result of ecological damage, theorizing that "In a sense, the earth is mounting an immune response against 
the human species" ${ }^{60}$ In spite of the fact that even pathogens like Yersinia pestis that are generally considered as more or less generically stable (and one even suspects "boring") from an emergence perspective have only evolved over tens (or maximum a few hundreds) of thousands of years, David Quammen, another important if more cool-headed proponent of the paradigm of emergence, reflects popular notions of human-led disturbance of "accommodation" when he claims that pathogens have "coevolved with their natural hosts over millions of years. They have reached some sort of accommodation, replicating slowly but steadily, passing unobtrusively through the host population". ${ }^{61}$ Whereas such pathogens used to "liv[e] tranquilly within their reservoir", "ecological disturbance causes disease to emerge", Quammen tells us: "Shake a tree, and things fall. Capture a bat for food, and you might catch something else too". ${ }^{62}$ Whether framing the impeding disaster in terms of shifting cultural practices, climate change, environmental degradation, or ecological collapse, these narratives share a vision of humanity's relation to the environment that identify the disturbance of a hitherto maintained equilibrium or "accommodation" as the cause of the next pandemic. ${ }^{63}$

This post-Cold War anxiety was further fueled by the mid-1990s Ebola outbreak in Central Africa, which generated extensive news coverage bolstered by popular fiction such as the blockbuster film Outbreak (1995), based on Preston's "terrifying true story" and directed by Wolfgang Petersen. This outbreak narrative identified the next pandemic as a result of a zoonotic spillover, a notion that commonly refers to the transmission of a virus harbored by an animal species to humans hitherto unaffected by it. In these conditions, human populations susceptible to the species-jumping virus would be "virgin", in the sense that no immunological mechanisms would be in place against it.

This is a vision of human extinction that relies on a complex operation of telescoping back and forth from the past into the future. It does this by mobilizing a range of "pandemic" tropes fit to different rhetorical purposes. First, the trope of the Black Death (a term used liberally to include the broad spectrum of the second plague pandemic rather than more accurately the first wave of it between 1346 and 1353) is mobilized in order to underline the impact of pathogens on human societies. Quoting debatable but frightening percentages, which are then applied to the entirety of "Europe" (a geographic entity conveniently left undefined), this pandemic image portrays plague as having killed "half", " $60 \%$ ", or "two thirds" of the population, leading to the desertion of cities, the collapse of agriculture, and so forth. No matter how much the actual history of the Black Death advances, complicating this picture and specifying the nonuniform or indeed not exclusively catastrophic impact of the disease in the fourteenth century, the societal collapse image persists with remarkable resilience. Second, the "Spanish flu" of 1918 is mobilized so as to underscore the way in which pandemics may be facilitated by modernity and its mechanized means of transport. ${ }^{64}$ The common cautionary tale accompanying "Spanish flu" stories is how quickly such a pathogen would spread in today's world of intercontinental air transport, free trade, and liberal democratic civil rights: "The underlying truth here is that, in the age of air travel, a disease anywhere can very quickly become a disease everywhere". ${ }^{65}$ 
At the same time, the pandemic imaginary relies on the nefarious image of pathogens like avian flu, which, according to Carlo Caduff, leading virologists like Robert Webster describe as a "killer strain lurking in the shadows" ${ }^{66}$ This is an image enthusiastically reproduced in popular cautionary articles and blogs about the next pandemic. Discussing Bill Gates' late interest in the "next pandemic", Kyle Harper warns us: "while modern medicine has the upper hand on many old microbial enemies, we should beware the sinister ability of pathogen evolution to thwart our cleverest weapons" ${ }^{67}$ Yet more importantly, according to Caduff, this emergence narrative ontologizes viruses-about-to-spillover as "indeterminate entities". ${ }^{68}$ So much so that in 2018 the WHO officially included in its "List of Blueprint priority diseases" "Disease X", stating that,

Disease $\mathrm{X}$ represents the knowledge that a serious international epidemic could be caused by a pathogen currently unknown to cause human disease, and so the R\&D Blueprint explicitly seeks to enable cross-cutting R\&D preparedness that is also relevant for an unknown 'Disease $\mathrm{X}$ ' as far as possible. ${ }^{69}$

Viruses are, as a result, seen as enemies of humankind that necessitate practices of vigilance, which in recent years have taken the biopolitical form of "pandemic preparedness": a regime of predictions, modeling practices, data-mining, syndromic surveillance, and sentinel watching that has been extensively examined by anthropologists..$^{70}$ If preparedness, or more broadly biosecurity, is a biopolitical regime that defines the Disease Diagram of emergence, as with all Disease Diagrams - Hinchcliffe et al. have noted it already - the latter has not simply come to replace the previous paradigm of epidemiological reasoning. ${ }^{71}$ Instead, it continuously strives to displace and integrate its guiding principles. This means not only that zoonotic cycles diagrams continue to be used where biopolitical institutions like the US CDC deem this to be beneficial, but also, more importantly, that a certain topology of infection has been carried over across the two zoonotic paradigms, so that it may be reconfigured according to the biopolitical and ontological principles of emergence. ${ }^{72}$ I would hence like to argue that although this continues to be a topology of "contact", through the latter's re-problematization, the Disease Diagram of emergence no longer maintains the dialectics of inclusion and inclusion examined above. It rather institutes a new interrelation between humans and animals, one that creates the conditions of possibility for a pandemic imaginary of human extinction.

\section{The question of entanglement}

If, for the sanitary-utopian Disease Diagram of zoonosis, contact between humans and nonhumans was the sine qua non of infection, it also signified a site of encounter that could be either purified (through disinfection), blocked (via ratproofing, or in the case of vector-borne diseases, mosquito nets), or altogether eliminated (by irrigation, incineration, or eradication). At the same time, the interaction between humans and nonhumans was rendered visible, intelligible, 
and actionable - all to the extent that it could be spatialized. ${ }^{73}$ Contact thus formed the par excellence topos for developing and exercising a triumphant mastery over human/nonhuman relations in spatial terms - the field of glory of hygienic modernity where sanitary utopias could be articulated, evinced, and achieved. It was, in other words, a field of pathogeny that was configured as spatially limited and legible and thus ultimately controllable. In this sense, the pre-emergence paradigm of zoonosis can be said to be governed by a topology of hope, which, as Rogaski has shown, was the general attribute of hygienic modernity. ${ }^{74}$

By contrast, in the case of the emergence Disease Diagram, although contact between humans and nonhuman animals continues to be at the center of epidemiological scrutiny, it involves a radically transformed topology. Where infection-control technologies, ranging from fire to chemical fumigation and DDT, used to form a cornerstone of modern hygienic imaginaries as the means by which human-animal separation was guaranteed, now pathogenic contact is portrayed as unstoppable - indeed, as the manifest destiny of human existence. As is often the case, this is made clear when we examine mythic renditions of emergence, as made available to millions of spectators by Hollywood. Consider, for example, the opening scene of the paradigm-setting film Outbreak. There we see a classic example of the implementation and exercise of human mastery on human/nonhuman relations as embodied by the zoonotic cycles diagram. The US Air Force, having identified an outbreak of a lethal zoonotic pathogen, firebombs the infected site. The scene may appear overly dramatic but it in fact draws on a long-established tradition of burning down plague-infected villages and urban neighborhoods (though not with inhabitants still in place) during the third plague pandemic. ${ }^{75}$ This scene should not, however, be seen as a mere castigation of military brutality or hygienic terror but as the indictment of topocentric epidemic control as an impotent means of halting the march of emergence. In the film, the virus re-emerges only a few decades later and thus begins its well-rehearsed march from tropical to concrete jungle. An equally evocative depiction of the impotence of topological sanitary intervention, and in particular of the now senseless reliance on barriers for epidemic containment, is evident in a more recent pandemic movie, World $\operatorname{War} Z$. There, as we will see in more detail in Chapter 4, Israeli efforts to insulate humans from viral zombies fail spectacularly when the Israel Defense Forces (IDF) decide to rely on the ultimate space-centered, and (following Wendy Brown's analysis of walls) sovereign, method for the protection of the few remaining uninfected citizens: city walls and fortifications. ${ }^{76}$ Confronted with the latter and excited by multi-faith prayers from behind the Jerusalem wall, the viral zombies simply form a swarm and leap over the (political theological) barrier, infecting all those enclosed within it. Whereas, in the age of hygienic modernity, site-focused interventions embodied the hope and promise of stamping out zoonotic infection, in the age of emergence they simply underline the supposed futility of any sovereign effort to prevent or block contact.

But contact is not rendered unstoppable without it first undergoing a diagrammatic transformation. What takes the place of topological contact in the case of 
emergence is a pathogenic human-animal relation whose operation becomes clear when we examine a key device of visualizing zoonosis: spidergrams. Void of any animal or human figures (the protagonists of zoonotic cycles), these are structured instead around components or drivers of infection: hunting, poverty, social cohesion, climate change, changes in animal husbandry methods, and so forth (Fig. 2.4).

These digital-epidemiological diagrams have been recently employed by scientists to capture the "spillover" or species-jump of the Ebolavirus from nonhuman animals to humans. ${ }^{77}$ Here, in these highly complex tools, the cybernetic causality of zoonotic cycles appears to be giving way to nexuses of "influence". What becomes established is a diffused evental ontology and, at the same time, a diffused form of responsibility. Simply put, the site of human intervention in this algorithmically generated web of emergence components becomes fundamentally undecidable; the lack of cybernetic causality in the Disease Diagram of emergence makes such topological intervention meaningless and futile. ${ }^{78}$ In the words of Lederberg et al., "in the context of infectious diseases, there is nowhere in the world from which we are remote and no one from whim we are disconnected". ${ }^{79}$ In the pre-emergence sanitary-utopian Disease Diagram, responsibility for maintaining human-animal separation, and thus halting infection, was clearly allocated to public and private partners, according to national and international legislation (think, for example, of port authorities' and ship owners' responsibility of killing rats and installing rat guards on international vessels). By contrast, today the supposed inability to decide what emergence component or relations between components should be acted upon promotes in the place of situated prevention the regimes of preparedness examined in detail by anthropologists like Andrew Lakoff, Limor Samimian-Darash, Carlo Caduff, and Frédéric Keck.

Aimed to seize the pathogenic rupture of the spillover event in their "networks of drivers", spidergrams configure infection as a question not of dialectical but of opportune time; in other words, a question of kairos, in the Hippocratic sense of the term, rather than of chronos. ${ }^{80}$ As is evident in inaugural texts of the particular paradigm, like Stephen Morse's "Factors in the Emergence of Infectious Diseases", the new Disease Diagram is heavily dependent on notions of opportunity. ${ }^{81}$ In the words of John Epstein, a veterinary disease ecologist interviewed by David Quammen, "the more opportunity viruses have to jump hosts, the more opportunity they have to mutate when they encounter new immune systems". ${ }^{82}$ The graphic efficacy of spidergrams hence depends precisely on their ability to show not only how different components are interlinked but also how the spillover is brought about when all of them align in an in/opportune conjunction. ${ }^{83} \mathrm{We}$ can then say that, in a manner that resembles astrological reasoning, this "aspect" becomes a plane of immanence where humans, animals, and their interrelation become indistinct and, at the same time, an exceptional process of ontogeny, in the course of which new diseases appear to "emerge" as they are being transmitted from nonhuman animals to humans.

This new configuration of human/nonhuman relations plays a key role in the pandemic imaginary by setting entanglement at the center of epidemiological 

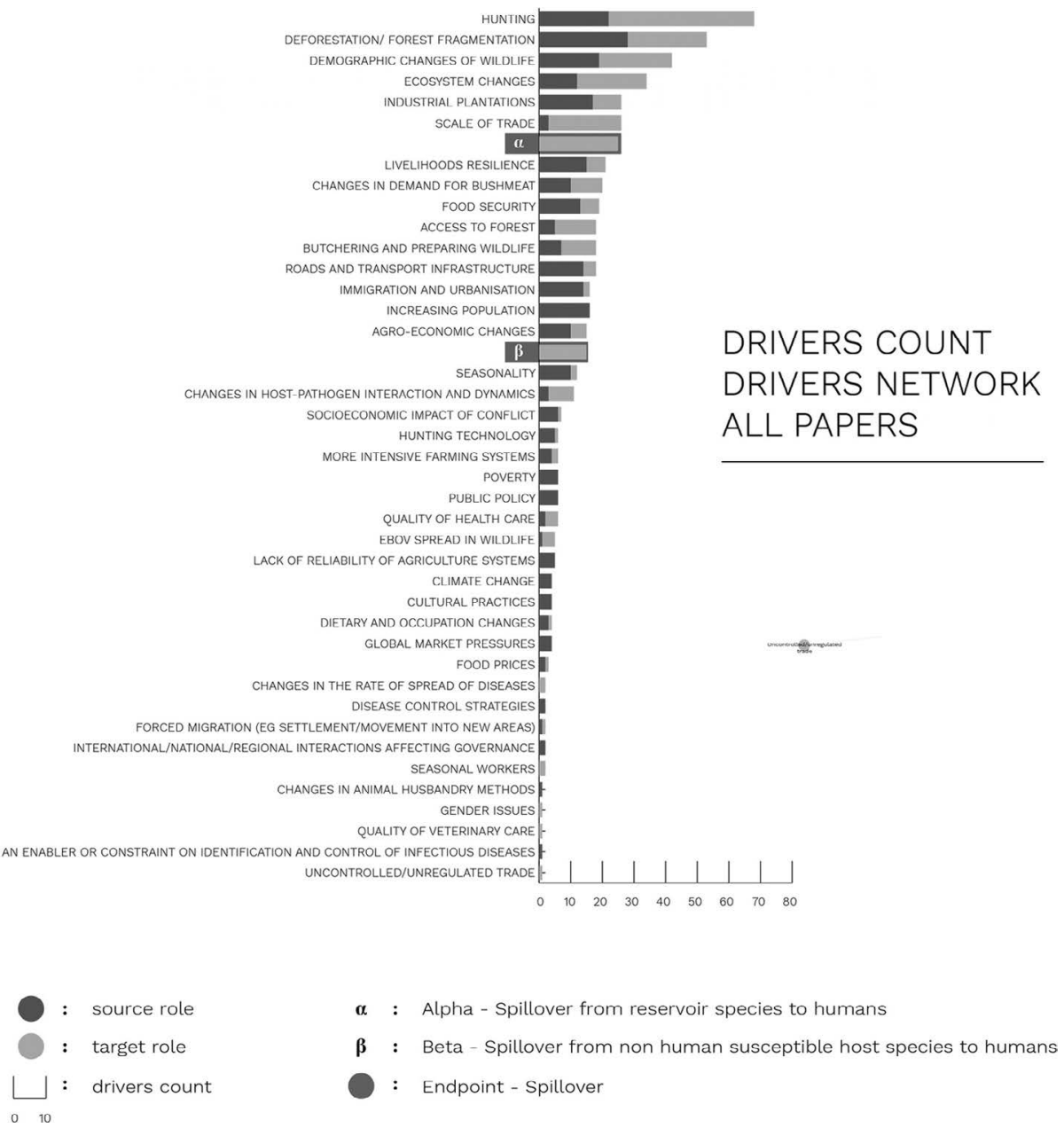

Figure 2.4 "Spidergram" showing Ebola spillover drivers (EFSA 2015).

Source: 2015, European Food Safety Authority

reasoning and, at the same time, of anticipations of human extinction. Indeed, emergence-focused epidemiological reasoning is imbued with a "relational and complexity-based thinking" that has been indicted as "sanction[ing] a shift to market-based solutions to biosecurity governance and to public-private interventions in molecular life". ${ }^{84}$ As a result, Hinchliffe et al. have argued,

the redistribution of responsibilities and the growing acceptance of radical uncertainty (as opposed to the more comforting calculus of known risk and determinate species) are coupled to an ontology of emergence and the 


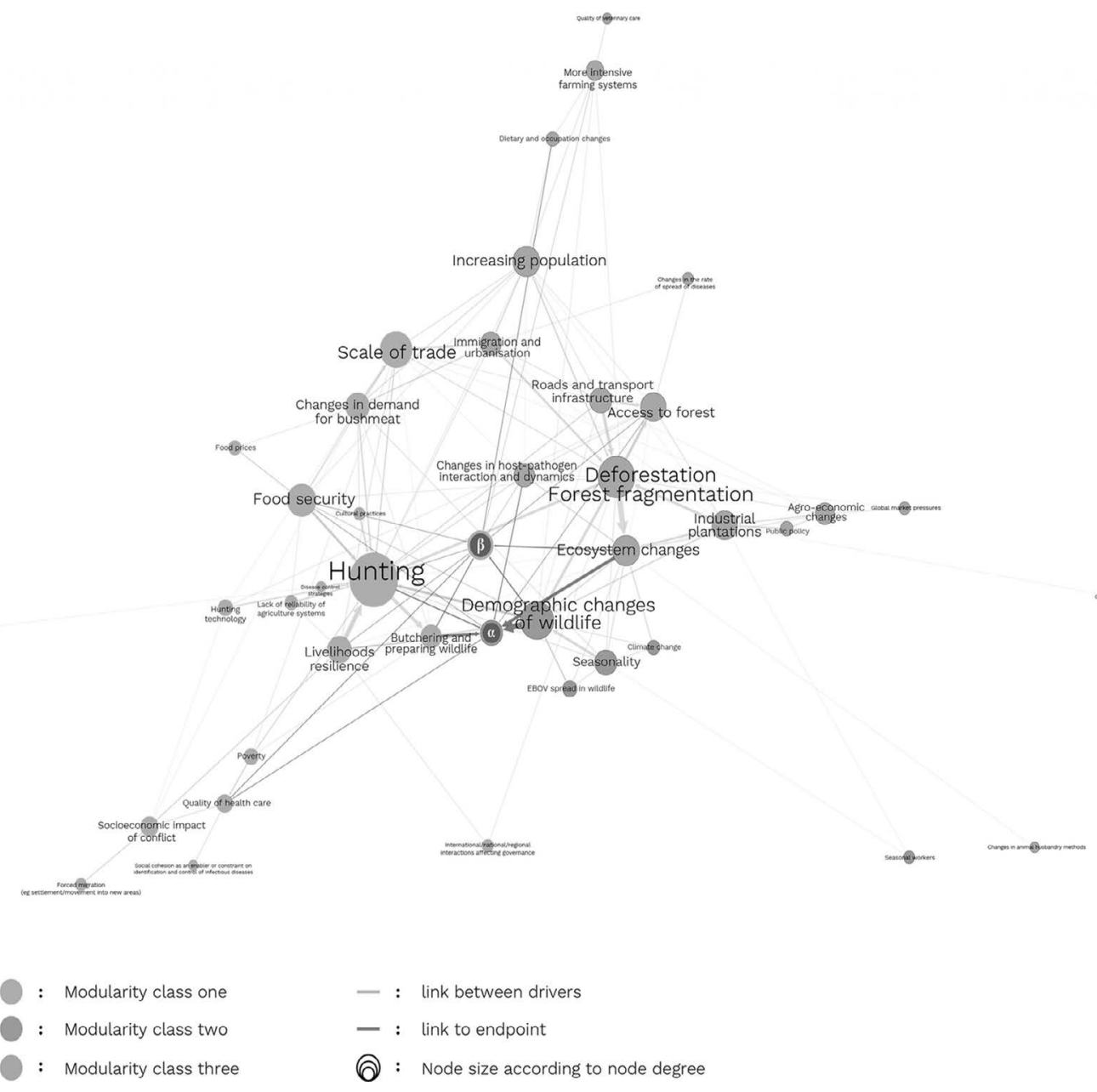

Figure 2.4 Continued

impending threat of emergency (with all its implications for governing society through fear). ${ }^{85}$

In this new configuration of zoonosis, human-animal contact continues to play a key role, though this is radically transformed. In the words of one of the most vocal prophets of the next pandemic, the "virus-hunter" Nathan Wolfe, "[i]ncreasing human contact with forested systems almost certainly leads to a corresponding increase in the emergence of infections in the human population". ${ }^{86}$ The vagueness and all-inclusive nature of contact in this context (examined extensively by Narat et al.) is aptly illustrated by the rhetorical chain of questions posed by Quammen regarding the 9-year-old victim of one of the first recorded Ebola 
cases, in 1977 Zaire: "Had she touched a dead chimpanzee, breathed rodent urine in a dusty shed, or pressed her lips to the wrong forest flower?" 87

Yet this should not lead us to assume that "contact" is a neglected, commonsensical notion that has remained inconsistent as a result of it having escaped scientific scrutiny. Rather we should see contact's vagueness as the categorical capaciousness of an excessive or "floating" signifier, which allows it to act as the pivot of the metaphysics of emergence. Contact thus becomes categorically available as the known-unknown end point of entanglement - the in/opportune chronotope where and when all enmeshed and intertwined factors and drivers lead to the event of emergence. This renders contact not simply another factor, on par with environmental degradation, cultural practices, development strategies, the political economy, urban planning, and so forth, but the element that preserves the economy of emergence: an element that may form part of an epidemiological system of knowledge only to the extent that it remains a knownunknown and thus, essentially, an object of divination or prophecy. ${ }^{88}$ Whereas, in the sanitary-utopian Disease Diagram of zoonosis, contact operated as a threshold, in the emergence Disease Diagram it occupies the role of a dispositif. As the organizing principle that allows the messy factors and interrelations of human/ nonhuman entanglement to assume meaning, by reaching a non-preventable conclusion, contact transforms all animal-human interaction into a preamble of a spillover event and the entirety of social life into the anteroom of human extinction. The way this is conveyed, fostering in turn a prophetic faculty at the heart of the pandemic imaginary, becomes clear once we examine the manner in which charismatic so-called grounds zero of emergence, such as South and Southeast Asia "wet markets", are visualized.

\section{Wet markets}

Sze-ki Liu, providing the only comprehensive ethnography of wet markets to date, traces the emergence of the live poultry and animal markets to periodic marketing practices in South China whose records for the area now comprising Hong Kong go back to the Ming dynasty. ${ }^{89}$ Taking over periodic markets and establishing live animal trade on a more day-to-day basis, wet markets began to become dominant in the region by the end of the nineteenth century. Liu does not provide us with a genealogy of these markets in the course of the turbulent twentieth century. Still, he stresses that today they stand in symbolic opposition to the supermarket, with the competition between the two trade pivots being played out over categories of hygiene, cleanliness, freshness, authenticity, tradition, and modernity.

At the same time, wet markets have been singled out as exotic, oriental sites in Euro-American guide books and media coverage of China, being recently featured as visit destinations for foodie gurus like Jamie Oliver and state leaders like Angela Merkel. ${ }^{90}$ Characteristic of this operation of orientalization is Quammen's reference to South Chinese wet markets as "vast bazaars" filled with exotic wild animals from China's mysterious hinterland.${ }^{91}$ In his popular nonfiction bestseller, Spillover, written in the tradition of Preston and Garrett, Quammen mobilizes 
a wide range of sensational and stereotypic narrative techniques so as to frame Chinese wet markets. In the chapter "Dinner at the Rat Farm", he situates eating non-domesticated animal meat (which he calls "eating wild") within wider licentious and potentially contagious practices supposedly taking post-socialist China by force, such as "patronizing a brothel where a thousand women stood on offer behind a glass wall". ${ }^{92}$ For Quammen, wet markets, as sources of hedonistic-cumpathogenic peril, are sites where one may encounter intriguingly diverse and endangered "wildlife" from the proverbial depths of Asia, such as the "Bornean river turtle" and the "Burmese star tortoise". This wild assortment of exotica is accordingly described as being squeezed and stacked in insalubrious cages bringing them, as well as domesticated animals, "in close contact" - a condition that, according to Quammen's scientific informants, "provide[d] a conducive environment [. . . ] for animal disease to jump hosts and spread to humans".93

Although, when seen in other contexts, such as Singapore, they are valorized as multicultural microcosms and "important communal space[s]", within the geosymbolic confines of "South China" wet markets have become synonymous with disorderly human to nonhuman animal relations and zoonotic emergence. ${ }^{94}$ The idea of China being home to bizarre animals that fail to fall under usual taxonomic categories is part and parcel of the colonial construction of the late-Qing Empire as a kingdom out of joint with the rest of the world. ${ }^{95}$ This narrative, which seems to have abated during the Maoist years (1949-1976), made a comeback during the SARS outbreak (2003) in the shape of widespread media fascination with the masked civet cat. As Mei Zhan has pointed out, this ambiguous animal, called humao in Chinese (literally meaning fox-cat), was portrayed on a symbolic level as a modern equivalent of the lascivious and highly dangerous mythic fox. ${ }^{96}$ It was moreover seen as a culinary partner of snakes (in the conspicuous and subsequently banned dragon-tiger Cantonese dish). Though mostly farmed, snakes were also considered lascivious in that their reproductive activity under captivity could not be regulated ${ }^{97}$ Identified as a potential source of the SARS coronavirus (SARS-CoV) by Hong Kong virologist Guan Yi (a link endorsed in the 2003 WHO's Consensus Document on the outbreak), the civet cat functioned as a prototype of "wet market" peril. ${ }^{98}$ It possessed all the symbolic traits for becoming the target of biopolitical suspicion: an unclear taxonomy, a resemblance to mythic tricksters and seducers, and an affinity of over-sexuality and lasciviousness with other suspect animals in the food chain. Yet civet cats were configured not only as ontologically but also as situationally polluting animals, through their in vivo display in the market. All the more, as I found out during my fieldwork among epidemiologists at one of China's Centers of Disease Control and Prevention in 2008, as civet cats were imagined to have been procured to the market by "roaming peasants": licentious, rootless individuals who were seen as consumers of "raw, rare and exotic meat" and thus as "animal-human bridges of contagion".

This multilayered symbolic configuration of pollution and disorder was further germinated by the powerful new idea of the spillover: the moment, as Steven Soderbergh's film Contagion (2011) puts it, when "the wrong pig m[eets] up with 
the wrong bat". Most importantly, what this symbolic configuration achieved was the constitution of the wet market as a publically recognizable epidemiological category. It should be remembered that during the 1997 H5N1 influenza outbreak, what during SARS came to be known as "wet markets" were simply referred to as "poultry markets". 99 Making for an explosive image of zoonotic threat, the civet cat thus came to stand for the South Chinese wet market in all its imagined exotic and pathogenic density, with photographic images of this metonymic operation reproduced in the print and electronic press.

This is not to question that, biologically speaking, the civet cat played a role in the wider ecology of SARS-CoV and, at least in the case of two individuals, in human SARS infection, though recent studies have cast serious doubt as to whether this is the virus's true reservoir. ${ }^{100}$ What is interesting from an anthropological perspective by contrast is how the photographic depiction of civet cats have come to populate the pandemic imaginary, so that, in the years following SARS, visual representations of disease emergence have become anchored on depictions of these markets, now empty of civets and filled with any number of other potential pandemic sources, as pandemic grounds zero.

In order to understand the photo-pathogenic configuration of the wet market and the way in which it contributes to the entanglement between science, policy, and the culture industry in the pandemic imaginary, we need to consider, even briefly, the broader historical context of epidemic photography.

\section{Epidemic photography}

Epidemic photography is a genre largely unexamined by visual studies, visual anthropology, or historians of medicine. Still, the term may be usefully employed to refer to the photography of outbreaks of infectious diseases, ranging from local or regional epidemics like the recent Ebola outbreak in West Africa to global pandemics like HIV/AIDS. Although the development of photographic technologies predate it by several decades, the emergence of epidemic photography can be traced to the third plague pandemic or at least to its principal phase, starting with the 1894 bubonic plague outbreak in Hong Kong and ending with the Los Angeles plague outbreak of 1924. The spread of the third plague pandemic was systematically recorded by the photographic lens in ways that transcended medical photographic conventions at the time. This was a new and dynamic genre that employed tools and methods deriving from diverse disciplines such as forensics, topography, architecture, urban planning, and ethnography, as well as street, war, and anthropometric photography. Its aim was to capture the first pandemic to be photographed (and to be bacteriologically understood) on a global scale in a manner that supplanted the microscope's ability to identify what plague was, with a complex portrait of what plague did.

As Jennifer Tucker has argued in her landmark study of Victorian scientific photography, by the end of the nineteenth century the application of photomicrography in the field of bacteriology yielded images of what advocates of germ theory like Robert Koch claimed to be the agents of diseases like anthrax or 
plague. This was an important epistemic and evidential moment so far as "Photomicrography [...] was crucial to the communication of scientific ideas in microscopy because it could fix the specimen so that viewers could be trained to see what was there". ${ }^{101}$ Diverging from Bruno Latour's doxology of the microscope, however, Tucker is careful to stress that in spite of Victorian excitement with this new technique of visualization, photomicrographic approaches of disease were mired in suspicion and disappointment as they could not show the main object of public and scientific controversy: whether bacteria did in fact cause disease and how. Tucker's study elaborates on how Koch mobilized drawings to cover this gap. More importantly, I would like to argue, at least in the case of plague, the crucial epistemic question regarding disease etiology was addressed through the engineering of a visual economy that had epidemic photography as its central structuring principle.

Although the visual configuration of plague also involved media such as maps, diagrams, drawings, and photomicrographs, what made photography central to this operation was, to follow Shawn Michelle Smith's retake on Walter Benjamin's notion of the optical unconscious, that it did not simply aim to reveal the secret of plague by rendering it visible. ${ }^{102}$ If we want to understand the ideological operation of epidemic photography (and photography in general), we need to follow Smith's syllogism that through it the Victorian viewer performed and embodied an awareness not only "of new visual realms but of what one could not and did not see", hence ushering in "a deeply uncanny sensibility [. . . ] the revelation and recognition that we inhabit a world unseen". ${ }^{103}$ Here then we have a double operation as regards photography's relation to epidemics. On the one hand, photography aimed to show what the microscope could not make visible (the cause and route of infection), while on the other hand, it aimed to reveal the epidemic in its enduring invisibility: as a process constituted by epistemic blind spots; a process, to use Smith's key term, unfolding "at the edge of sight".

It can be thus claimed that plague photography, as the first and paradigmatic form of epidemic photography, operated simultaneously on the levels of a demonstrative and a forensic faculty - demonstrative in that it revealed what had already been there, what had led to the disaster at hand. Bad sewers, faulty roofs and floors, overcrowding, hunting malpractices, narrow streets, "primitive" burial rites, insanitary pilgrimage practices, eating improper food, sleeping on the ground, walking barefoot: these were some of the imagined causes of plague outbreaks at the time. Consequently, this demonstrative faculty of plague photography related to who was to be blamed on a local, national, and imperial governmental level. But also who was to be blamed on a class or racial level and on the level of cultural practices (coolies, fakirs, native elites, etc.; pilgrimage, "fatalism", wild animal hunting, etc.). Yet photography also had a forensic faculty in that, like crime photography, it captured the scene of the event not so much as to represent what was known to be there, but so as to create a total disciplinary archive of it. The purpose of this was, as Henry Bond has elaborated in his book Lacan at the Scene, to be able to provide evidence in the course of future criminal, or in our case epidemiological, investigations. ${ }^{104}$ 
Like in crime scene photography one cannot see the criminal, in plague photography one cannot see plague. And yet it is not only its trace that is visible. For, as Michel Foucault elaborated in his lectures Abnormal, in the course of nineteenthcentury medico-juridical discourse, the criminal act progressively became part of the criminal. The criminal was completely identified with his or her act. ${ }^{105}$ Hence, photographing a crime scene was to photograph the act that was criminal; in other words, the criminal as a character rather than as an individual. In a similar way, at the end of the nineteenth century, photography aimed to capture plague as a disease rather than as a pathogen. What plague did was what plague really was - in other words, plague's so-called character. As a result, plague was not limited to what one could see under the microscope but expanded to include all the effects of plague on the human body and on human society.

Plague photography as an epidemiological rather than bacteriological apparatus was hence not simply a photography of "what-has-been", in Roland Barthes' sense of the term, but also a photography of "what-has-been-invisible" or, to return to Smith, what lies at the edge of sight. ${ }^{106}$ It referred not so much to the event of this or that outbreak but to the invisible thread connecting this outbreak with outbreaks to come. This is not the same operation as what Christopher Pinney, writing in relation to the Amritsar massacre, saw as photography's ability to witness and preserve an event ${ }^{107}$ - for the lens of plague photography was not focused so much on evidence of a past occurrence as on evidence of a future already contained in the past. Its aim was to generate an archive of the terrain of plague - a total record of what was imagined to be the environment or milieu where plague manifests itself, so that, with the development of further knowledge on the disease, future scientists could study this archive and draw vital conclusions and methods for eradicating plague. It was this colonial apparatus, rather than the microscope, that promised to capture the "character" of plague; in other words, plague as not-yet-manifested, plague that-will-be-manifested, and plague as what is always already here.

Before the "emergence of emergence", epidemic photography provided a visual field whose central principle was human mastery over human/nonhuman relations as a topological mastery of contact. By contrast, as becomes obvious when examining the visualization of wet markers, the photography of disease emergence disallows the hope of mastery and institutes in its place a prophetic faculty void from the promise of a disease-free future.

\section{Prophetic photography}

Following the recent, post-retirement reflections on the next pandemic by US CDC's ex-PHPR director, Ali Khan,

the virus will quietly spread from rat to rat or squirrel to squirrel, year after year out in the jungle, and you'll never know it except for the sporadic human infection. Then suddenly, out of the blue, you've got a new human epidemic on your hands. ${ }^{108}$ 
In relation to this temporal imaginary of emergence, the photography of wet markets takes as its explicit subject what Frédéric Keck has called emerging infectious disease sentinels (civet cats, ducks, geese, etc.). ${ }^{109}$ Keck has argued that "sentinel devices [...] stand on the border between the visible and the invisible, the known and the unknown" and that as such "they equip prophetic claims to act on the environment". ${ }^{110}$ His claim comes as a response to Carlo Caduff's notion of pandemic prophecy. ${ }^{111}$ Caduff's analysis focuses on the contested efficacy of predictions of emergent pandemics, which, he claims, "are not necessarily based on scientific evidence in the strict sense of the term, but they are nevertheless pronounced in a scientific manner and thus appear to be scientifically inspired". ${ }^{112}$ Relating this to the "cosmology of mutant strains", Caduff has claimed that this symbolic investment on viral indeterminacy has led to the "normalization and naturalization of the unknown [. . .] as an ontological given". ${ }^{113}$ Yet, as Michaël Fœssel notes, "it is only when the end of the world is integrated into a theory of action that prophecy transforms into a lesson of prudence", a process that, Caduff claims, involves prophecy as the mythic ground for the biopolitics of pandemic preparedness. ${ }^{114}$ If, as Quammen puts it, zoonosis "is a word of the future", this is because the next pandemic has been configured as humanity's destiny - a fact witnessed by the repetition, uttered as a divinatory lament, of what is arguably Louis Pasteur's least rigorous scientific statement: "Gentlemen, it is the microbes who will have the last word". ${ }^{115}$

In order to approach the question of pandemic forecasting anthropologically, we, however, need to return to the notion of prophecy from a new, critical perspective. In Limn's issue on "sentinel devices", Frédéric Keck and Andrew Lakoff attempted a synoptic exploration of what they call "figures of warning". ${ }^{116}$ When it comes to prophecy, their brief but evocative description provides a turn of phrase that may be easily overlooked, when it in fact holds the key to understanding the prophetic faculty of pandemic enunciations: "Prophets are [...] figures facing the king with dreams that mysteriously indicate a discrepancy between the law and the world". ${ }^{117}$ Rather than someone who simply forecasts or foretells, in the sense of proclaiming the future before it happens, the etymology of the prophet in Greek [prophêtis] indicates someone who speaks before, or in the face of, an audience. In order to elucidate the importance of this positioning, we thus need to approach the question of pandemic prophecy not from the perspective of apocalyptic theology or by classic anthropological works on divination (Zande, Kalanga, Mambila, Afro-Cuban, etc.) but in the context of a specifically medical practice, prevalent in Greek and Roman in antiquity - one that is evident in the work of the ancient world's most influential physician: Galen. ${ }^{118}$

It is well known that the second-century Greek physician from Pergamum often wrote of being guided by dreams in making diagnosis. As Classics scholars like Holowchak and Hulskamp have noted, Galen considered these dreams to be indistinguishably diagnostic and prophetic. Whereas many were experienced as messages sent by Asclepius (as exemplified in the incubatory tradition), not all were. ${ }^{119}$ Dating back to the Hippocratic Regimen IV (written between the fifth century and 320 bce), dreams were often considered a result of bodily disposition 
(diathesis), such as humoral imbalance. Most importantly, a great number of prophetic/diagnostic dreams recounted by Galen were experienced as deriving from the soul, which, in his words, "having slipped into the depth of the body and having withdrawn from external, sensible things - seems to perceive the condition throughout the body". ${ }^{120}$

This is a point that Michel Foucault overlooks when he famously claims that the prophetic position is paradigmatically mediatory: "The prophet, by definition, does not speak in his own name. He speaks for another voice; his mouth serves as intermediary for a voice which speaks from elsewhere". ${ }^{121}$ Rather than being confined to charismatic individuals, this prophetic/diagnostic position could be occupied by anyone trained in medicine, so that cases of patients acting as prophets of their own dreams were not unknown, Galen himself being a well-known example. Moreover, for Galen dreams could take several forms, some explicit, others symbolic; yet, in all cases when these medical prophecies were spoken out, in public, they acquired an unambiguous diagnostic form. Hence, again contra Foucault, medical prophecy in Galen's practice, entailed a "univocal and clear prescription"; it did "bluntly speak the pure, transparent truth". ${ }^{122}$ Unlike the Delphic oracle, whose efficacy, as Buxton has argued, was constituted by humanity's inability to fully grasp the meaning of the signs, Galen's medico-prophetic enouncements functioned in a way that Foucault could only have recognized as parrhesianist, but which we need not limit so. ${ }^{123}$

Galen delivered his dream-derived diagnosis standing before his patient, his social surrounding, and, in several cases, rival physicians. ${ }^{124}$ This social and agonistic, highly performative mode of truth-telling is structurally congruent with the visual enouncement delivered by wet market photography. If Galenic medical prophecy was an act of selecting certain elements from the patient's dream and interpreting/presenting them unambiguously as the result of or foretelling a critical humoral imbalance, wet market photography similarly selects elements from the complex social reality of live animal markets and interprets/presents them as the result or foretelling of an inopportune conjunction of human/nonhuman relations. $^{125}$

If we are to follow the schema introduced by Eric Dodds, according to which in Archaic Greece poets were to the truth-telling of the past as prophets were to the truth-telling of the future, we could say that the demonstrative and forensic faculties of epidemic photography occupy the former position (the dialectic between what has been and what is invisible), while its prophetic faculty the latter ( $t$ ' essomena or "that which is to be", in Hesiod's terms - Th.32). ${ }^{126}$ Whereas not all epidemic photography possess a prophetic faculty (at least in an active form), in the case of wet market photography, the latter overdetermines the poetic faculties that usually imbue the visual configuration of epidemic processes or events. In other words, it mobilizes the demonstrative and forensic capacities of the image in the public enunciation of the next pandemic. As with Galen's dreams, the visual performance of pandemic prophecy is unambiguous, clear, and unriddle-like: what is depicted in the photograph is the once and future pandemic ground zero" 127 ; in other words, the "structural position on a border where events 
occur". ${ }^{128}$ Every element in these photographs signifies not so much an agent, sentinel, amplifier, or link of infection and transmissibility as an opportunity for emergence: the true origin of the pandemic end of the world. These, in Barthes' terms, are photographs that are meant to be (and yet not always succeed in being) all-studium, no-punctum. They are photographs whose pandemic frame is meant to transform every element in them (animals, birds, cages, stalls, water pools, pavements, humans, proximities, shades, and textures) into a sign of pandemic opportunity and, ultimately, into the origin of human extinction.

\section{Zoonosis transformed}

As diagrammatic and photographic transformations of what, following Marouf Hasian, we may call elite and vernacular visions of zoonosis make evident, disease emergence heralds the end of human mastery. ${ }^{129}$ On the one hand, through rendering "contact" a floating signifier, it fosters an approach of animal-human infection that essentially replaces knowledge with divination as a process of knowing that there is a knowledge that we do not possess. On the other hand, through the institution of a prophetic ontology at the heart of expectations of the next pandemic, it transforms the entire field of human-animal interaction into the "ground zero" of human extinction. In terms of the pandemic imaginary, this transformed zoonosis is thus not simply a mechanism generating risk for human health and well-being. Instead, it is a symbolic field that produces an image of the end of the world as a condition that is always already preconfigured by an ontological indistinction between humans and nonhuman animals that comes to pervade human-animal interaction as the origin of the end of humanity.

\section{Notes}

1 Cover page, New Scientist 3020, May 9-15, 2015.

2 Charles Baldwin was an environmental health engineer who was then working for the Dow Chemical company.

3 David Quammen (2014: 23) identifies both Ebola and Marburg as "wormy viruses".

4 The inaccurate but persistent notion that Ebola is a "flesh-eating" virus was promoted by Richard Preston in his 1994 book The Hot Zone.

5 Vilheml Slomann, Bicorporates: Studies in Revivals and Migrations of Art Motifs. Copenhagen: Munksgaard, 1967. See also: A. David Napier, Masks, Transformation, and Paradox (Berkeley: University of California Press, 1986).

6 In his examination of masks, David Napier (1986) has noted the apotropaic similarities between the figure of the Gorgon and bicorporates.

7 Daniel Heller-Roazen, The Enemy of All: Piracy and the Law of Nations (Cambridge, MA: MIT Press, 2009), 168.

8 Heller-Roazen, The Enemy of All, 168.

9 See especially the works of Carlo Caduff and Frédéric Keck.

10 Guillermo del Toro and Chuck Hogan, The Strain, "Night Zero," Season 1, Episode 1 (13 July 2014). The FX series is based on the best-selling homonymous book by Guillermo del Toro and Chuck Hogan (2009).

11 Benjamin in Giorgio Agamben, The Fire and the Tale, translated by Lorenzo Chiesa (Stanford, CA: Stanford University Press, 2017), 58-59. 
12 Agamben, The Fire and the Tale, 59.

13 David Quanmmen, Ebola: The Natural and Human History (London: The Bodley Head, 2014), 2.

14 Ross Upshur, Jerome Singh and Nathan Ford, "Apocalypse or Redemption: Responding to Extensively Drug-Resistant Tuberculosis," Bulletin of the World Health Organization 87 (2009): 481.

15 Nicholas B. King, "The Scale Politics of Emerging Diseases," Osiris 2nd Series 19 Landscapes of Exposure: Knowledge and Illness in Modern Environments (2004): 62-76.

16 The term "zoonosis" already appears in medical dictionaries by the end of the nineteenth century (Gould 1894; Dorland 1900) but remained little used until the 1940s. For a spectrum of histories of animals and their role in modern medicine, see: Abigail Woods, et al. (eds.), Animals and the Shaping of Modern Medicine: One Health and Its Histories (London: Palgrave Macmillan, 2017); Anne Hardy, "Animals, Disease and Man: Making Connections," Perspectives in Biology and Medicine 46(2) (Spring 2003): 200-215.

17 Myron J. Echenberg, Plague Ports: The Global Urban Impact of Bubonic Plague, 1894-1901 (New York: New York University Press, 2007).

18 Ruth Rogaski, Hygienic Modernity, Meaning of Health and Disease in Treaty-Port China (Berkeley, CA: The University of California Press, 2004).

19 An exception could be made as regards the disease known as Mahamari in the Indian Himalayas, which some British medical officers suspected to be plague; British Library, India Office Records and Private Papers, Mahamari disease (fever) prevailing in Garhwal IOR/F/4/2472/138452: 1836-1851. For the later significance of this find, see: House of Commons Parliamentary Papers [C.2262] Parliamentary Session: 1878-79, Plague. Papers relating to the modern history and recent progress of Levantine plague, prepared from time to time by direction of the president of the Local Government Board, with other papers.

20 Neil Pemberton, “The Rat-Catcher's Prank: Interspecies Cunningness and Scavenging in Henry Mayhew's London," Journal of Victorian Culture 19(4) (2014): 534.

21 Alexandre Yersin, "La Peste Bubonique a Hong Kong," Annales de l'Institut Pasteur 8 (1894): 662-667. For discussion of Yersin's discovery, see: David J. Bibel and T. E. Chen, "Diagnosis of Plague: An Analysis of the Yersin-Kitasato Controversy," Bacteriological Reviews 40(3) (September 1976): 633-651; Henri H. Mollaret and Jacqueline Brossollet, Yersin: Un pasteurien en Indochine (Paris: Belin, 2017).

22 Emile Rocher, La Province Chinoise du Yunnan (Paris: Lerous, 1879); Alexander Rennie, "Report on the Plague Prevailing in Canton during the Spring and Summer of 1894," Imperial Customs Maritime Report for the Year Ended 30th September, 1894, 47th and 48th issues; J. L. Michoud, "Report on the Health of Mengtsz for the Year Ended 30th April 1894," China Imperial Maritime Customs Medical Reports, 1894, Special Series, No. 2.

23 Marc Simond, et al., "Paul-Louis Simond and His Discovery of Plague Transmission by Rat Fleas: A Centenary," Journal of the Royal Society of Medicine 91(2) (February 1998): 101-104.

24 On the notion of epidemiological villains, see: Frédéric Keck and Christos Lynteris, "Zoonosis: Prospects and Challenges for Medical Anthropology," Medicine Anthropology Theory, in print.

25 On maritime deratization, see: Lukas Engelmann and Christos Lunteris, Sulphuric Utopias: The History of Maritime Fumigation (Cambridge, MA: MIT Press, in print).

26 See for example: Projit Bihari Mukharji, "Cat and Mouse: Animal Technologies, Trans-Imperial Networks and Public Health from Below, British India, c. 19071918," Social History of Medicine https://doi.org/10.1093/shm/hkx024; Branwyn Poleykett, "Building Out the Rat: Animal Intimacies and Prophylactic Settlement in 1920s South Africa," American Anthropological Association Engagement, February 7, 
$2017 \mathrm{https}: / /$ aesengagement.wordpress.com/2017/02/07/building-out-the-rat-animalintimacies-and-prophylactic-ssettlement-in-1920s-south-africa/

27 R. H. Creel, "The Rat: A Sanitary Menace and an Economic Burden," Public Health Reports (1896-1970) 28(27) (4 July 1913): 1403.

28 Creel, "The Rat: A Sanitary Menace and an Economic Burden," 1403.

29 Isadore Dyer, The Rat, the Flea and the Plague: Some Plain Facts for the Public: Prepared for the Medical Plague Conference Committee of New Orleans (Place of publication not identified: New Orleans Medical Plague Conference Committee, 1912), 1.

30 It should be noted here that zoonoses do not include vector-borne diseases like malaria, whose vector (the mosquito) was identified in 1897.

31 Warwick Anderson, "The Possession of Kuru: Medical Science and Biocolonial Exchange," Comparative Studies in Society and History 42(4) (2000): 713-744.

32 Nicholas H. Evans, "Blaming the Rat? Accounting for Plague in Colonial Indian Medicine," Medicine, Anthropology, Theory 5(3):15-42 https://doi.org/10.17157/mat.5.3.371; Mark Honigsbaum, "'Tipping the Balance': Karl Friedrich Meyer, Latent Infections, and the Birth of Modern Ideas of Disease Ecology," Journal of the History of Biology (2015) doi:10.1007/s10739-015-9430-7; Karen Sayer, “The 'Modern' Management of Rats: British Agricultural Science in Farm and Field during the Twentieth Century," British Journal for the History of Science 2 (2017): 235-263 http://dx.doi. org/10.1017/bjt.2017.7; Susan D. Jones and Anna A. Amramina, "Entangled Histories of Plague Ecology in Russia and the USSR," History and Philosophy of the Life Sciences 40(49) (2018) https://doi.org/10.1007/s40656-018-0220-3; Genese Marie Sodikoff, "The Multispecies Infrastructure of Zoonosis," In The Anthropology of Epidemics, eds. Frédéric Keck, Ann H. Kelly and Christos Lynteris, pp. 102-120 (London and New York: Routledge, 2019); Projit Bihari Mukharji, "Cat and Mouse: Animal Technologies, Trans-Imperial Networks and Public Health from Below, British India, c. 1907-1918," Social History of Medicine 31(3) (2017):510-532 doi:10.1093/shm/ hkx024

33 Key texts promoting a lab-centric history of medicine since the 1870 s include: Bruno Latour, The Pasteurization of France (Cambridge, MA: Harvard University Press, 1988); Andrew Cunningham, "Transforming Plague: The Laboratory and the Identity of Infectious Disease," In The Laboratory Revolution in Medicine, eds. Andrew Cunningham and Perry Williams, pp. 209-244 (Cambridge: Cambridge University Press, 1992). For critiques of lab-centrism, see: Michael Worboys, Spreading Germs Disease Theories and Medical Practice in Britain, 1865-1900 (Cambridge: Cambridge University Press, 2000); Robert Peckham, "Matshed Laboratory: Colonies, Cultures, and Bacteriology," In Imperial Contagions: Medicine, Hygiene, and Cultures of Planning in Asia, eds. Robert Peckham and David M. Pomfret, pp. 123-147 (Hong Kong: Hong Kong University Press, 2013); Christos Lynteris, Ethnographic Plague: Configuring Disease on the Chinese-Russian Frontier (London: Palgrave Macmillan, 2016).

34 Rohan Deb Roy, "Nonhuman Empires, Comparative Studies of South Asia," Africa and the Middle East 35(1) (May 2015): 70.

35 A. Bacot, George F. Petrie and Captain R. E. Todd, "The Fleas Found on Rats and Other Rodents, Living in Association with Man, and Trapped in the Towns, Villages and Nile Boats of Upper Egypt," Journal of Hygiene 14(4) (December 1914): 498508; North Manchurian Plague Prevention Service, "The Role of the Tarbagan in the Epidemiology of Plague," North Manchurian Plague Prevention Service Reports (1918-1922): 83-98; Lukas Engelmann, "Fumigating the Hygienic Model City: Bubonic Plague and the Sulfurozador in Early-Twentieth-Century Buenos Aires," Medical History 62(3) (2018): 360-382 doi:10.1017/mdh.2018.37

36 The particular diagrammatic regime was introduced in the 1930s and it reached its standard form in the context of post-Second World War epidemiology.

37 Hans-Jörg Rheinberger, Toward a History of Epistemic Things: Synthesizing Proteins in the Test Tube (Stanford, CA: Stanford University Press, 1997). 
38 Karl F. Meyer, “The Ecology of Plague," Medicine 1(2) (1942): 147, 156.

39 Karl F. Meyer, "Sylvatic Plague," American Journal of Public Health 28(10) (1938): 1153-1164. Examples of linear zoonotic diagrams can be found in: L. Rogers and J. W. D. Megaw, Tropical Medicine (London: J. \& A. Churchill, 1930); Wu Lien-teh, W. H. Chun and Roger Pollitzer (eds.), Plague: A Manual for Medical and Public Health Workers (Shanghai: National Quarantine Service, 1936).

40 This was a diagram that drew on Charles Elton's visualization of food cycles forming a visual apparatus central to emerging ecological approaches of infectious disease in terms of infective chains; see: Charles Elton, Animal Ecology (London: Sidgwick and Jackson, 1927).

41 See, for example, Davey and Lightbody (1961), where the zoonotic cycles take the form of rolling conveyor belts, completing the cybernetic image with a Fordist touch.

42 Christos Lynteris, "Zoonotic Diagrams: Mastering and Unsettling Human-Animal Relations," Journal of the Royal Anthropological Institute N.S. 23(3) (September 2017): 463-485.

43 Tim Ingold, Lines: A Brief History (London and New York: Routledge, 2007).

44 I am grateful to Frédéric Keck for bringing to my attention the "dead end" epidemiological metaphor with respect to this aspect of the diagram.

45 Christine M. Boeckl, Images of Plague and Pestilence: Iconography and Iconology (Kirksville, MO: Truman State University Press, 2000).

46 Giorgio Agamben, The Open: Man and Animal, translated by Kevin Attell (Stanford, CA: Stanford University Press, 2004), 37.

47 Tom Mitchell in A. Smets, et al., "Image Notation, Graph ..." In What Is an Image?, eds. J. Elkins and M. Naef, pp. 91-104 (University Park: Pennsylvania State University Press, 2011), 99.

48 Philippe Descola, Beyond Nature and Culture, translated by Janet Lloyd (Chicago: The University of Chicago Press, 2013), 172.

49 Agamben, The Open, 37. It is this dialectic between inclusion and exclusion that is missed by Hinchliffe et al. (2016) in the otherwise significant contribution to the discussion of "pathological lives".

50 Steven Hinchcliffe, et al., Pathological Lives: Disease, Space and Biopolitics (London: Wiley-Blackwell, 2016), 27.

51 Eugene Thacker, "The Shadows of Atheology, Epidemics, Power and Life after Foucault," Theory, Culture \& Society 26(6) (2009): 134-152.

52 See Introduction.

53 Victor Narat, et al., "Rethinking Human: Nonhuman Primate Contact and Pathogenic Disease Spillover," EcoHealth 14(4) (2017): 840-850.

54 King, "The Scale Politics of Emerging Diseases," 65.

55 King, "The Scale Politics of Emerging Diseases," 67.

56 Nicholas B. King, "Security, Disease, Commerce: Ideologies of Postcolonial Global Health," Social Studies of Science 32(5-6) Postcolonial Technoscience (OctoberDecember 2002): 767.

57 King, "The Scale Politics of Emerging Diseases," 70.

58 Richard Preston, "Crisis in the Hot Zone," New Yorker (26 October 1992): 80.

59 Laurie Garrett, The Coming Plague: Newly Emerging Diseases in a World Out of Balance (New York: Farrar, Straus and Giroux, 1994). For a sustained analysis of Garrett's book and her overall impact on Global Health, see: Lisa Lynch, "The Neo/ Bio/Colonial hot Zone: African Viruses, American Fairytales," International Journal of Cultural Studies 1(2) (1998): 163-196; Marouf A. Hasian, Jr., Representing Ebola: Culture, Law, and Public Discourse about the 2013-2015 West African Ebola Outbreak (Lantham, MD: Rowan and Littlefield, 2016), Chapter 6.

60 Richard Preston, The Hot Zone: A Terrifying True Story (New York: Anchor 1994), 287.

61 David Quammen, Ebola: The Natural and Human History of a Deadly Virus (New York: W. W. Norton \& Company, 2014), 77. 
62 Quammen, Ebola, 36, 4.

63 This doctrine is best encapsulated in Garrett's "coming plague" subtitle: "Newly Emerging Diseases in a World Out of Balance".

64 Carlo Caduff, The Pandemic Perhaps: Dramatic Events in a Public Culture of Danger (Berkeley, CA: University of California Press, 2015).

65 Ali Khan with William Patrick, The Next Pandemic: On the Front Lines against Humankind's Gravest Dangers (New York: Public Affairs, 2016), 95.

66 Carlo Caduff, "Pandemic Prophecy, or How to Have Faith in Reason," Current Anthropology 55(3) (2014): 297.

67 Kyle Harper, "How Microbes Have Destroyed Civilisations in Catastrophic Biological Events," Star2.com, December 16, 2017, accessed December 17, 2017 www.star2. com/health/2017/12/16/microbes-can-destroy-civilisations/

Bill Gates has introduced the next pandemic in his existential risk repertoire with frequent performances of pandemic forecasting, which are readily adopted by a wide range of news platforms and science media.

68 Caduff, "Pandemic Prophecy, or How to Have Faith in Reason," 300.

69 World Health Organization, List of Blueprint Priority Diseases, February 2018 www. who.int/blueprint/priority-diseases/en/

70 Carlo Caduff, "Sick Weather Ahead: On Data-Mining, Crowd-Sourcing, and White Noise," The Cambridge Journal of Anthropology 32(1) (June 2014): 32-46; Frédéric Keck, Un monde grippé (Paris: Flammarion, 2010); Teresa MacPhail, "A Predictable Unpredictability: The 2009 H1N1 Pandemic and the Concept of "Strategic Uncertainty' within Global Public Health," Behemoth 3 (2010): 57-77; Andrew Lakoff, Unprepared: Global Health in a Time of Emergency (Berkeley, CA: University of California Press, 2017).

71 Hinchcliffe, et al., Pathological Lives: Disease, Space and Biopolitics.

72 See in particular the use of CDC infographics for Ebola during the recent epidemic in West Africa: Lynteris, "Zoonotic Diagrams: Mastering and Unsettling Human-Animal Relations"; Michelle Ziegler, "The Evolution of Ebola Zoonotic Cycles," Contagions, 2017, https://contagions.wordpress.com/2017/11/11/the-evolution-of-ebola-zoonoticcycles/

73 For a broader discussion of space in the "government of species", see: Neel Ahuja, Bioisecurities: Disease Interventions, Empire, and the Government of Species (Durham, NC: Duke University Press, 2016).

74 Rogaski, Hygienic Modernity.

75 See, for example, the torching down of Honolulu's Chinatown; James C. Morh, Plague and Fire: Battling Black Death and the 1900 Burning of Honolulu's Chinatown (Oxford: Oxford University Press, 2006).

76 Wendy Brown, Walled States, Waning Sovereignty (Cambridge, MA: Zone Books, 2010).

77 EFSA (European Food Safety Authority), "Drivers for Occasional Spillover Event of Ebola Virus," EFSA Journal 13(6) (2015): 4161 [46 pp.] doi:10.2903/j.efsa.2015.4161, p. 3.

78 On how this is instituted in Preston's writing, see: Heather Schell, "Outburst! A Chilling True Story about Emerging-Virus Narratives and Pandemic Social Change," Configurations 5(1) (Winter 1997): 93-133.

79 Joshua Lederberg, et al., Emerging Infections: Microbial Threats to Health in the United States (Washington, DC: National Academy Press), v.

80 For a discussion of kairos and chronos in epidemic emergencies, see: Christos Lynteris, "Epidemics as Events and as Crises: Comparing Two Plague Outbreaks in Manchuria (1910-11 and 1920-21)," The Cambridge Journal of Anthropology 32(1) (Spring 2014): 62-76.

81 Stephen S. Morse, "Factors in the Emergence of Infectious Diseases," Emerging Infectious Diseases 1(1) (1995): 7-15.

82 Quammen, Ebola, 79. 
83 Johanna Drucker, Graphesis: Visual forms of Knowledge Production (Cambridge, MA: Harvard University Press, 2014). For a development of epidemiological reasoning about emergence and "opportunity", see: Quammen, Ebola.

84 Hinchcliffe, et al., Pathological Lives: Disease, Space and Biopolitics, 41.

85 Hinchcliffe, et al., Pathological Lives: Disease, Space and Biopolitics, 41. On notions of uncertainty and disease emergence also, see: Celia Lowe, "Viral Clouds: Becoming H5N1 in Indonesia," Cultural Anthropology 25(4) (2010): 625-649; Frédéric Keck, "Sentinel Devices: Managing Uncertainty in Species Barrier Zones," In Modes of Uncertainty: Anthropological Cases, eds. Limor Samimian-Darashand Paul Rabinow, pp. 165-181 (Chicago: The University of Chicago Press, 2015).

86 Nathan D. Wolfe, et al., "Wild Primate Populations in Emerging Infectious Disease Research: The Missing Link?," Emerging Infectious Diseases 4 (1998): 149-158. For analytical perspectives on "virus hunters", see: Frédéric Keck, "L'alarme d'Antigone. les chimères des chasseurs de virus," Terrain 64 (2015): 3-19; Guillaume Lachenal, "Lessons in Medical Nihilism: Virus Hunters, Neoliberalism, and the AIDS Pandemic in Cameroon," In Para-States and Medical Science: Making African Global Health, ed. Paul Wenzel Geissler (Durham, NC: Duke University Press, 2015); Christophe Perrey, Un ethnologue chez les chasseus de virus. Enquête en Guyane française (Paris: L'Harmattan, 2012). Lachenal notes Wolfe's contribution to the rise of epidemiological interest in bushmeat hunting and consumption as a source of emergence in Africa, but also his contribution to the film I Am Legend - yet another way in which science, policy and the cultural industry have become entangled.

87 Victor Narat, et al., "Rethinking Human: Nonhuman Primate Contact and Pathogenic Disease Spillover"; Quammen, Ebola, 30.

88 Agamben (2017: 53) usefully notes that "what the diviner knows is only that there is a knowledge that he does not know, from which derives its association with mania or possession".

89 Sze-ki Liu, "An Ethnographic Comparison of Wet Markets and Supermarkets in Hong Kong," The Hong Kong Anthropologist 2 (2008): 1-51.

90 Mimi Lau, "Angela Merkel Begins Visit to China with Trip to Sichuan Wet Market," The South China Morning Post, July 6, 2014, accessed December 10, 2014 www. scmp.com/news/china/article/1548104/angela-merkel-begins-visit-china-trip-sichuan-wet-market; Susan Jung, "Selfie Frenzy as Jamie Oliver Tours Hong Kong Market and Restaurants," The South China Morning Post, March 24, 2015, accessed March 29, 2015 www.scmp.com/lifestyle/arts-culture/article/1746348/selfie-frenzyjamie-oliver-tours-hong-kong-market-and

91 David Quamenn, Spillover: Animal Infections and the Next Human Pandemic (London: W. W. Norton \& Company, 2012), 188.

92 Quamenn, Spillover, 188.

93 Quamenn, Spillover, 189.

94 C. Zheng, "Relevance of Traditional Wet Markets, as a Communal Space That Promotes Community Bonding, in Singapore's Public Housing Estates," Asian Urban Epicenters: Collaborative Platform for Sharing Thoughts on Asian Urbanism http:// asianurbanepicenters.com/? $\mathrm{p}=1734$

95 Robert Peckham, "Game of Empires: Hunting in Treaty-Port China," In Eco-Cultural Networks and the British Empire, eds. James Beattie, Edward Mellilo and Emily O'Gorman, pp. 202-232 (New York and London: Bloomsbury, 2014).

96 Mei Zhan, "Civet Cats, Fried Grasshoppers, and David Beckham's Pajamas: Unruly Bodies after SARS," American Anthropologist N.S. 107(1) (March 2005): 31-42.

97 Zhan, "Civet Cats, Fried Grasshoppers, and David Beckham's Pajamas: Unruly Bodies after SARS," 35.

98 World Health Organisation (WHO), Consensus Document on the Epidemiology of SARS, 2013 www.who.int/csr/sars/en/WHOconsensus.pdf 
99 This is not to mean that the term had not been used before in medical research, yet its use was limited to campylobacters, salmonella, and listeria, and unconnected to the notion of emergence or spillover (see, for example, Hassan et al. 2001).

100 Changchun Tu, et al., "Antibodies to SARS Coronavirus in Civets," Emerging Infectious Diseases 10(12) (2004): 2244-2248; Huai-Dong Song, et al., "Cross-Host Evolution of Severe Acute Respiratory Syndrome Coronavirus in Palm Civet and Human," Proceedings of the National Academy of Sciences of the United States of America 102 (2005): 2430-2435; Lin-Fa Wang and Bryan T. Eaton, "Bats, Civets and the Emergence of SARS," Current Topics in Microbiology and Immunology 315 (2007): 325-344; Ming Wang, "SARS-CoV Infection in a Restaurant from Palm Civet," Emerging Infectious Diseases 11(12) (2005):1860-1865; Paul K. S. Chan and Martin C. W. Chan, "Tracing the SARS-Coronavirus," Journal of Thoracic Disease 5(S2) (2013): S118-S121.

101 Jennifer Tucker, Nature Exposed: Photography as Eyewitness in Victorian Science (Baltimore: Johns Hopkins University Press, 2013), 166.

102 Walter Benjamin, "The Work of Art in the Age of Mechanical Reproduction," In Illuminations, translated by Harry Zohn, pp. 217-251 (New York: Schocken, 1969 [1936]). On Walter Benjamin's notion of the optical unconscious, see: Rosalind Krauss, The Optical Unconscious (Cambridge, MA: The MIT Press, 1993); Shawn Michelle Smith (ed.), Photography and the Optical Unconscious (Durham, NC: Duke University Press, 2017).

103 Shawn Michelle Smith, At the Edge of Sight: Photography and the Unseen (Durham, NC: Duke University Press, 2013), 4.

104 Henry Bond, Lacan at the Scene (Cambridge, MA: MIT Press, 2009).

105 Michel Foucault, Abnormal: Lectures at the Collège de France, 1974-1975, translated by Graham Burchell (London: Picador, 2004).

106 Roland Barthes, Camera Lucida, translated by Peter Howard (New York: Hill and Wang, 1981).

107 Christopher Pinney, "The Prosthetic Eye: Photography as Cure and Poison," Journal of the Royal Anthropological Institute N.S. 14 (Issue Supplement S1) (April 2008): 33-46.

108 Ali Khan with Patrick, The Next Pandemic: On the Front Lines against Humankind's Gravest Dangers, 79.

109 Frédéric Keck, Un monde grippé (Paris: Flammarion, 2010); Frédéric Keck, "Une sentinelle sanitaire aux frontières du vivant: Les experts de la grippe aviaire à Hong Kong," Terrain 54 (2010): 26-41.

110 Frédéric Keck, "Untitled" [Comment to C. Caduff "Pandemic Prophecy, or How to Have Faith in Reason"], Current Anthropology 55(3) (June 2014): 309.

111 Caduff, "Pandemic Prophecy, or How to Have Faith in Reason."

112 Caduff, Pandemic Prophecy, or How to Have Faith in Reason," 298.

113 Caduff, "Pandemic Prophecy, or How to Have Faith in Reason," 298, 304.

114 Michaël Fœssel, Après la fin du monde, Critique de la raison apocalyptique (Paris: Seuil, 2012), 27, my translation.

115 Quammen, Ebola, 3; Khan, The Next Pandemic, 259.

116 Frédéric Keck and Andrew Lakoff, "Figures of Warning," Limn 3 (June 2013) http:// limn.it/figures-of-warning/

117 Keck and Lakoff, "Figures of Warning."

118 Prominent examples include: Susan Reynolds Whyte, Questioning Misfortune: The Pragmatics of Uncertainty in Eastern Uganda (Cambridge: Cambridge University Press, 1997); Margaret Lock, "Breast Cancer: Reading the Omens," Anthropology Today 14(4) (August 1998): 7-16.

119 Mark Holowchak, "Interpreting Dreams for Corrective Regimen: Diagnostic Dreams in Greco-Roman Medicine," Journal of the History of Medicine and Allied Sciences 56(4) (October 2001): 382-399; Maithe A. A. Hulskamp, Sleep and Dreams in Ancient Medical Diagnosis and Prognosis. PhD Thesis, Newcastle University, 2008. 


\section{Zoonotic transformations}

120 Susan P. Mattern, Prince of Medicine: Galen in the Roman World (Oxford: Oxford University Press, 2013); Galen, On Diagnosis from Dreams, in Holowchak, "Interpreting Dreams for Corrective Regimen," 388, n. 17.

121 Michel Foucault, The Courage of the Truth (The Government of Self and Others II): Lectures at the Collège de France, 1983-1984, translated by Graham Burchell (Basingstoke: Palgrave Macmillan, 2011), 15.

122 Foucault, The Courage of the Truth, 15.

123 Richard G. A. Buxton, "Blindness and Limits: Sophokles and the Logic of Myth," Journal of Hellenic Studies 100 (1980): 22.

124 Mattern, Prince of Medicine.

125 Holowchak, "Interpreting Dreams for Corrective Regimen". For other examples of this kind of photography, see: Natalie Porter, "Bird Flu Biopower: Strategies for Multispecies Coexistence in Việt Nam," American Ethnologist 40(1) (2013): 132-148.

126 Eric R. Dodds, The Greeks and the Irrational (Berkeley, CA: University of California Press, 1951).

127 Melinda Liu, "Is China Ground Zero for a Future Pandemic?," Smithsonian Magazine, November 2017, accessed December 10, 2017 www.smithsonianmag.com/ science-nature/china-ground-zero-future-pandemic-180965213/

128 Frédéric Keck, "From Purgatory to Sentinel: 'Forms/Events' in the Field of Zoonoses," Cambridge Anthropology 32(1) (Spring 2014):51.

129 Hasian, Representing Ebola. 


\section{Anthropogenesis reversed}

In April 2009, news of a suspected outbreak briefly dominated the Russian media. The story run that a 23-year-old Chinese woman riding a Moscow-bound train from the city of Blagoveshchensk, on the Amur River, died before reaching Zuyevka Station in Kirov Oblast. ${ }^{1}$ The train was stopped and decoupled at Zuyevka where 52 Chinese and 7 Russian passengers were taken into isolation. At the same time, Novosti news reported,

Sanitary cordons were set up in Russia's Far East to prevent the spread of the suspected disease. Security measures were tightened to control the entry of Chinese citizens entering Russia. All passengers had to pass a medical examination before they were allowed to travel. ${ }^{2}$

The rumor, spread by radio, television, and on the Internet, spoke of a new outbreak of SARS. The fear of a return of the lethal coronavirus was further fueled by a statement by the Russian General Prosecutor's Office that, "the passenger's death was due to acute respiratory viral infection, pulmonary oedema and cerebral oedema". ${ }^{3}$ Such was the uproar that the Chinese embassy in Moscow was forced to officially refute the allegation (April 16, 2009), claiming the case to be common pneumonia. ${ }^{4}$ Regardless, a frenzy of disinfecting trains entering South Siberia from China ensued, with several wagons carrying Chinese citizens being immobilized, uncoupled, and sprayed in Chita.

This was as much an epidemiological as an economic panic - the two, as Robert Peckham has recently shown, being often intricately linked. ${ }^{5}$ In 2003, the SARS outbreak had forced Russia to seal ten key border-passes to China, leading the province of Heilongjiang to suffer an economic slump but also causing serious economic problems for the Russian oblast of Chita. In the following years, SARS scares became a light motif in the region. When, for example, in April 2006, news that two children from Atamanovka (in the Chita oblast) were hospitalized bearing signs of bird flu, a wave of panic ensued. The kids were said to have played with a sick wild migratory bird in the woods, which authorities believed to have entered Russia from China. Failing to detect the influenza virus, doctors in Chita were quick to diagnose "acute respiratory viral infection", which was mistranslated as SARS in the local press; the confusion 
regarding the identity of the disease fueled suspicion and accusatory practices for some time. ${ }^{6}$

Such cross-border, interspecies infection fears and accusations are not a new phenomenon in the world in general and in East Asia in particular. The Northeastern Chinese-Russian border, to take one example that has preoccupied my own research, has a long and complex history of international and interspecies infection, with pneumonic plague playing a major role in the biopolitical problematization of cross-border traffic in Republican China, since the devastating Manchurian outbreak of 1910-1911.7 And yet what differentiates the question of quarantine and disinfection as applied, say, to the Chinese Eastern Railway in the 1910s from today's infected train scenarios is not a quantitative increase in traffic volume (that has by no means been linear or constant) but rather a qualitative change engulfing epidemiological reasoning and the pandemic imaginary.

When in spring 2003, overcoming the initial shock and bafflement, epidemiologists started unraveling the infection pathway of the SARS pandemic, available models proved unable to explain the rapid dissemination of the causative coronavirus (SARS-CoV). It was from this epidemiological lacuna that a new figure emerged; a figure that filled what we may call the "epidemio-logical" gap, and was quickly transformed into much more than just a rhetorical way out of modeling embarrassment: the superspreader. ${ }^{8}$ It is on the basis of this figure that incidents of minor epidemiological significance, such as the ones sketched above, may assume global proportions as heralds of the "next pandemic".

This chapter will explore the way that the figure of the superspreader operates in epidemiological reasoning and the pandemic imaginary as "a hallmark of emerging infections that are jumping from animal to human hosts". ${ }^{9}$ By tracing this operation I will follow two interlinked analytical trajectories. First, I will explore the biopolitical operation of the superspreader, focusing on the way in which this figure shifts attention away from infrastructural and processual causes of heterogeneous transmissibility and toward the figure of an exceptional individual or human type. In doing so, I will lay out how this fosters a shift to neoliberal biopolitics that severs the critical potential of thinking about such incidents as based on social and political economic processes. Second, I will explore the superspreader as a mythic figure: a threshold between two modes of existence by grace of its anti-Promethean qualities. Demonstrating how the pandemic imaginary entails a vision of reversed anthropogenesis, the superspreader will be shown to be a key figure in a process through which humanity is led into a somber ontological realm of not-being-human and yet also not-being-animal.

If they indeed derive from different trajectories in Western thinking about humans and their place in the world, these two aspects of the superspreader one biopolitical, the other mythic - should not be seen as separate or as simply complementary. Instead, it is precisely unwrapping their synergy in instituting, at one and the same time, a neoliberal epidemiological reasoning and an extinctionist pandemic imaginary that is at stake here. For if Catherine Keller is right to note that the end of the world "literalizes itself in history", the superspreader should be seen as a figure that, on the one hand, embodies contagion in the present, as 
the principle behind our pandemic-borne non-future, while, on the other hand, transforming the future end of humanity to a present loss in the world, through the implementation of ever tighter neoliberal regimes of preparedness. ${ }^{10}$

\section{The superspreader hypothesis}

Let us then begin by examining the basic parameters of what we may call the superspreader hypothesis. A cornerstone principle in modern epidemiology and a key to epidemiological modeling is the so-called basic reproduction number or ratio, $\mathrm{R}_{0}$ (pronounced " $\mathrm{r}$ nought"). This refers to the average number of persons an individual infects in the course of the disease's transmissibility phase. The basic modeling idea is that if $\mathrm{R}_{0}$ is smaller than one, then the disease in question will not be able to spread and become epidemic. In other words, it will not be able to generate infection across a given human population. If, on the other hand, $\mathrm{R}_{0}$ is greater than one, then its ability to spread across a population is considerable; the larger the basic reproduction number, the more prolific the spread of the pathogen. ${ }^{11}$ In the case of a superspreading event, what is supposed to occur is that one or more individuals trespass this fundamental law of infection by manifesting a capacity to spread pathogens to an unusually large number of contacts (i.e., a number unusually high for the particular disease). Transmission to at least eight individuals is the categorization threshold for being considered a "superspreader", although this presumably does not apply to measles where the $\mathrm{R}_{0}$ is between 12 and $18 . .^{12}$

If this description appears cloaked in the ennui of biometric technicality, mass media and popular science platforms have easily managed to overcome both the burden of statistical language and the broader epistemological problems surrounding the notion of $\mathrm{R}_{0} \cdot{ }^{13}$ In ways that are anything but subtle, superspreaders have been tagged as hyper-infectors and portrayed as "people who are 'full of the virus' and capable of infecting a large pool of people". ${ }^{14}$ Most striking, they are depicted as "people [who] are hyperinfective, spewing germs out like teakettles, while others simmer quietly like stew pots". ${ }^{15}$ This metaphor is telling, for it both indicates and fosters a perception of superspreaders not simply as hypothetical figures from whom a large number of people may contract a disease but as actual individuals who spread the disease to an inordinately large number of people. The difference here is subtle yet crucial, for it underlines the biopolitical status of the superspreader as an individual not simply implicated in but responsible for an epidemic: someone who is a "teakettle" rather than a "stew pot". And, at the same time, it transforms superspreaders from hypothetical into mythic figures, paradoxically by affording for them a flesh and blood reality; that is, a biosocial incarnation.

In her exploration of the genealogy of the superspreader, Priscilla Wald has underlined its affinity with a pivotal figure of early twentieth-century epidemiological reasoning: Typhoid Mary, as Mary Mallon, an immigrant Irish cook accused of spreading typhoid across the USA in the 1900 s came to be known. ${ }^{16}$ Still, Wald is right to emphasize that while Typhoid Mary is portrayed in both popular science media and scientific papers as the first superspreader, she in fact embodied a very 
different biopolitical and at the same time mythic operation. ${ }^{17}$ In contrast to the "unwitting role" of contemporary superspreaders, she was supposed to be aware of the fact that she was a "healthy carrier" spreading the disease. She was, in other words, a modern-day, biomedical untora (smearer) or purposeful spreader of pestilence, like the ones imagined as and accused of being responsible for spreading plague in early modern Lombardy. ${ }^{18}$ As a result, she was embedded in what we may call an imaginary longue durée regarding the malicious spread of epidemic disease. With the difference that, by grace of not being involved in a plaguespreading conspiracy or cabal, Mary Mallon's transformation into Typhoid Mary remained a strictly individual phenomenon. It was this combined continuity with lost-established imaginaries of purposeful disease transmission and discontinuity from their sociological anchorage, through its immersion into a new reading of the human body, which arguably made Typhoid Mary such a successful epidemic icon. For, as Wald has argued, Typhoid Mary underlined the interdependence of "social responsibility and bacteriological individualism" or what we may call the bacteriological biosociality of the modern condition. ${ }^{19}$

By contrast, rather than simply spreading disease, as Typhoid Mary or the Milanese untori before her were supposed to have done, today superspreaders are seen as individual agents who "bring the virus itself to life". ${ }^{20}$ The paradigmatic case of this ontogenesis, on the basis of which the epidemiological image of the superspreader has been largely instituted, was Dr. Liu Jianlun. A recent article in the Hong Kong Post Magazine reflects the lingering status of this original superspreader:

On February 21, 2003, Liu Jianlun, a doctor from Guandong province, travelled to Hong Kong and checked into Kowloon's Metropole Hotel. He was feeling under the weather. Eleven days later he died in hospital. Severe acute respiratory syndrome (Sars) [sic] had arrived in Hong Kong. ${ }^{21}$

According to this recounting of events, on the night of February 21, 2003, Dr. Liu stayed in room 911 of the Metropole Hotel, checking out the following day. Thirteen people residing in the same hotel that night were infected (these are sometimes taken up to 20), with Liu being identified by epidemiologists as the index case - in other words, the source of their infection. ${ }^{22}$

According to the World Health Organization's Consensus Document on SARS, "the Metropole Hotel, Kowloon, Hong Kong SAR cluster exemplified the potential international spread of infectious diseases", with US CDC and WHO researchers noting that the transmission "led to export the virus to several other countries". 23 The WHO in particular pointed out that "the results of environmental sampling on the carpet outside room 911 [...] and elevator area show a hot zone (possibly vomitus or respiratory secretions)". ${ }^{24}$ In other words, the 13 or 20 infected guests of the Metropole Hotel were supposed to have come in contact with these "hot zones" harboring active coronaviruses, where from they contracted the disease, henceforth spreading it across the globe. The forensic mentality of this conclusion is typical of epidemiological reasoning, which as a rule proceeds by reducing 
the complexity of social life to linear cause-effect threads, which can in turn furnish coherent and actionable outbreak scenarios. From this perspective, it is claimed that up to half of the total 8,100 SARS patients across the globe can be "traced back to" Dr. Liu. ${ }^{25}$ The recollections of the US CDC's PHPR ex-director, Ali Khan, regarding the identification of the ultimate source of SARS's global spread strike a characteristic tone regarding the "discovery" trope underscoring this origin story:

We drew up a diagram, using data gathered by lots of hard-working detectives around the world. Then we mapped the index cases from each country, then drew a line to the place where each was thought they have become infected. All lines converged on Hong Kong, and more, specifically, the Hotel Metropole Hotel! This was a case in which a picture was indeed worth a thousand words. ${ }^{26}$

If superspreaders do indeed "offer myths for the contemporary moment", as Wald claims, what is pertinent from an anthropological point of view is to investigate not how these stabilize any given outbreak narrative but how they transform epidemiological reasoning and integrate it within a wider pandemic imaginary. ${ }^{27}$ This operation, I would like to argue, depends on the reconfiguration of superspreading from an infrastructural process into an individualized event.

\section{From process to event}

The complex interrelation between the processual reality of epidemics and their phenomenological exceptionality, as well as the ways in which some epidemics function as sociopolitical events, have been extensively examined by anthropologists in recent years. ${ }^{28}$ Insofar as it can be said to function as a catalyst not only of microbiological but also of ideological contagion, what the figure of the superspreader does is to transform infectious disease outbreaks from socioecological processes to individualized events, hence reducing their syndemic complexity to a linear and often skeletal chain of causality. This it does by identifying any given outbreak with a limited number of individuals who thus acquire an overarching explanatory and indeed dramaturgical faculty. ${ }^{29}$ Superspreaders are, as a result, conceived as catalysts of global contagion, with one superspreading incident being considered as enough to ignite a chain reaction of infection, which can in turn quickly transform into a pandemic of existential risk proportions.

Such was, for example, feared to be the eventual course of events in the 20122013 case of the Middle East Respiratory Syndrome (MERS), caused by another coronavirus (MERS-CoV). ${ }^{30}$ As cases began to appear not only in the Middle East but also in Europe, Helen Branswell of The Canadian Press rang the usual medical-journalist alarm in an article warning that "superspreaders could turn new coronavirus into SARS-like event". ${ }^{31}$ According to this account, "SARS went global because of a superspreader", who was none other than Dr. Liu of the Metropole Hotel. Asserting that "some people [... .] seem to spew more virus [sic] 
than other", the article provided readers with the seemingly unequivocal opinion of Michael Osterholm, director of the Center for Infectious Diseases Research and Policy, at the University of Minnesota: "Is there a potential here for a superspreader to be in our midst? I think absolutely. Yes". ${ }^{32}$ Hence, Branswell argues that, "if someone with a superspreading capacity were to take the virus from the Middle East to another country, that could ratchet up the risk". ${ }^{33}$ This pandemic prophecy entails a vision of superspreaders as a sine qua non of the next pandemic.

In examining the effects of this aspect of epidemiological reasoning and its impact on public health policy, it is worth taking a closer look at one of the most influential studies of superspreading to date - published in Nature in November 2005, Lloyd-Smith et al.'s “Superspreading and the Effect of Individual Variation on Disease Emergence", proposed to be "an integrated theoretical and statistical analysis of the influence of individual variation in infectiousness on disease emergence". ${ }^{34}$ Far from being a phenomenon limited to SARS, the authors argue, "superspreading is a normal feature of disease spread". ${ }^{35}$ They hence stipulate "the need to identify predictive correlates of higher infectiousness". ${ }^{36}$ Although, in the supplementary information provided alongside the study, the authors recognize superspreading as conditioned upon environmental factors, in their main text they present an image that is unambiguously individual-centered - all the more as they introduce a variable whose role they promote as corrective to the supposedly variation-distorting $\mathrm{R}_{0}$ : the so-called individual reproductive number $v$, "a random variable representing the expected number of secondary cases caused by a particular infected individual". ${ }^{37}$ The authors thus went on to claim, "diseases with high individual variation show infrequent but explosive epidemics after the introduction of a single case. This pattern recalls SARS in 2003". ${ }^{38}$

In the days following its publication, Lloyd-Smith et al.'s Nature paper was successfully promoted through a press release by the lead author's institution, UC Berkeley. Its close reading illuminates the biopolitical potential underlying the paper. According to the press release, the researchers claim that, "an individual is at greater risk of being a superspreader if he or she has a job that brings him or her into frequent, close contact with a large number of people" such as health professionals. ${ }^{39}$ Rather than focusing on structural aspects of heterogeneous transmissibility, however, the authors clearly privilege the exceptional individual, with one of them elaborating on "the factors that make an individual a superspreader", these being "both genetic and behavioural components". ${ }^{40}$ More pointedly, LloydSmith is quoted as saying: "For diseases like SARS, major outbreaks occur when disease hits the jackpot by infecting a superspreader" ${ }^{41}$ We need to pay close attention to this oft-repeated gambling trope, for what it seems to be presuming is that someone is a superspreader before being infected by the disease; in other words, that there is a particular human type who can be accurately described as a superspreader in the waiting. To say that a disease infects a superspreader is the same thing as saying that it infects an infant, a woman, a man, a widow, a nurse, or a student. In other words, it presumes a pre-existing biological, social, or behavioral subject that may then interact with the environment so as to produce 
infection, which is however essentially independent of the latter. Simply put, from this perspective, an individual does not become a superspreader under certain circumstances; instead, he or she is always already a superspreader, even if the "chance" of infection never arises.

There is no doubt that the transmission of pathogens from human to human is not a homogeneous process and that in different contexts different individuals end up infecting a smaller or a larger number of contacts, what is known as heterogeneous transmissibility. What the institution of the superspreader does is not to invent or fabricate a phenomenon but to frame and configure it as the result of individual exceptionality. To examine how this takes place is crucial for our understanding of the operation of the superspreader vis-à-vis the specter of human extinction. According to a study by Zhuang et al., "superspreading appeared to be associated with a greater number of contacts and SARS developed in a high-proportion of those contacts $(\mathrm{P}<0.025)$ ". ${ }^{42}$ Zhuang, however, notes that the comparison in hand does not take into account the susceptibility of contacts. We thus learn that "it is likely that the contacts of patient A represented a vulnerable population, since $36(76 \%)$ of her contacts were other hospitalized patients" and that patients that evinced no superspreading abilities "had relatively close contacts (range 1-4), which suggests limited opportunities for transmission instead of intrinsic differences in the transmissibility of their illness". ${ }^{43}$ Clearly then, while there may be individuals in any given outbreak from whom disease is transmitted to a larger number of people than the designated $\mathrm{R}_{0}$, this does not automatically renders them a priori superspreaders. Instead, the most significant driver of heterogeneous transmissibility may be sought in what, following Hannah Brown and Ann Kelly, we may call complex and entangled "material proximities" - identified in recent Ebola-based studies as "spatial and temporal dynamics of superspreading". 44

What about the famous SARS superspreaders of Hong Kong then? In its Consensus Document on SARS, the WHO is careful to stress a detail whose absence is conspicuous in popular science articles and in a large number of scientific papers: "Although the Metropole Hotel outbreak is recognized as a 'superspreading event', the index case in this outbreak did not have an unusually high viral load when tested on days 9 and 11 of the illness". ${ }^{45}$ In other words, whereas there was a superspreading incident, the index patient was not a superspreader in the sense of having an innate capacity, irrespective of circumstances, to spread the virus to more people than other patients. The second case we need to examine here under the same light is the so-called superspreading incident at the Amoy Gardens apartments in Hong Kong, where more than 300 persons were said to have been infected by a single index patient. The superspreader in the case was identified as a 33-year-old man from Shenzhen who had come to Hong Kong so as to be treated for a chronic renal disease at the Prince of Wales Hospital. ${ }^{46}$ On the night of March 14, 2003, the said individual spent the night at his brother's flat, number 7, in Block E of the Amoy Gardens estate where he developed diarrhea. It is to the timing of this symptom in the particular infrastructural context that the superspreading event should be attributed. According to the WHO, "dry traps in 
bathroom drains provided a conduit for contaminated sewage droplets to enter households. A significant virus load has built up in the sewer system as an increasing number of SARS cases with diarrhoea exerted virus". ${ }^{47}$ In other words, the fact that the patient sought relief from diarrhea in his brother's toilet, burdened as this was with a particular infrastructural fault, led to the spread of virus-carrying fecal droplets across the complex and its rapid dissemination in other flats of the Amoy Gardens Block E.

Whereas what occurred in Amoy Gardens was a superspreading incident in the sense of a large number of individuals being infected by viruses carried in the index patient's excrements, the patient could not be said to innately be a superspreader. Although the 33-year-old man's urine and feces were found to have a high concentration of virus, the incident was clearly more related to complex material proximities resulting from faulty housing infrastructure than to any individual characteristic or indeed "character" of the patient. ${ }^{48}$ If the sewage system had not been faulty, then the backflow from the risers in the drainpipes would not have produced an aerosol, spreading the virus in other toilets in the block. ${ }^{49}$ The "tea kettle" spewing germs in this case was not the patient but rather the sewage system where he inadvertently chose to deposit his infected excrement. Similarly, if we take a third famous superspreader case, the one related to the Chek Lap Kok airport (Hong Kong) worker (the first case to be hospitalized at the Prince of Wales Hospital on March 5, 2013), a similar pattern becomes evident. If SARS-CoV did spread from the airport worker to a large number of individuals, this was because he was treated with a nebulizer, which sprayed surrounding patients with the virus. ${ }^{50}$ Again, while this was a superspreading incident, the subject implicated in superspreading was more the doctor or nurse who used the nebulizer than the index patient himself. What caused the superspreading incident in this case was inadequate medical training and/or strained human resources and infrastructural capacity, not the individual carrying the virus. If we really want to point at the source of "spewing germs" in the Prince of Wales Hospital, this was none other than the postcolonial healthcare economy of Hong Kong.

What I want to underline here is simple: the focus on the figure of the superspreader, in the sense of an evental subject, a biologically exceptional individual who regardless of context or circumstance transmits a given disease to more people than normal, rather than on contexts of heterogeneous transmissibility, not only disregards the syndemic nature of any outbreak but also generates an urgency whose biopolitical function is to reproduce neoliberal states of exception to the expense of socially oriented public health and healthcare.

We often read about the "lesson of SARS", be that a lesson taught by journalists and academics or by the director-general of the WHO herself. ${ }^{51}$ The notion itself, as Katherine Mason's work has shown, is erroneous and riddled with ethnographic problems when its application is examined on the ground. ${ }^{52}$ From my own ethnographic experience in post-SARS China, an incident remains engrained in my mind. It was one of those typical late spring afternoons in Beijing, when the desert sand blowing from Mongolia begins to give way to an electric atmosphere. Seated on a covered leather armchair, in a generously furnished office, I 
tried to focus my attention away from the rasp of the polyethene under me and repeat the question: So what was it, in the end, that put an end to the spread of SARS five years ago? The high-ranking epidemiologist seated opposite me held one of those lucrative double posts one often comes across in China: professor at a medical faculty and officer in a key disease control institution of the People's Republic. "We do not really know", he replied, "why it went or where it's gone". But what will you do if SARS returns one day? I retorted. In a tone perched between a lament and a scoff, the epidemiologist replied: "Exactly what we did last time".

Indeed, if we are to look for the concrete lesson of SARS superspreaders in particular, this is none other than the supposedly urgent need for draconian surveillance and containment (i.e., what the PRC's epi-apparatus did "last time"). This is a regime of biosecurity that applies, on a first level, to contacts and whose exceptional nature becomes clear once we take a look at the rules guiding what counted as a "close contact" needing isolation in the case of SARS. The Consensus for the Management of SARS of the Chinese Medical Association (PRC) enumerates the following:

(1) Persons who were in close contact with symptomatic, suspected, or probable SARS patients for a length of time in their daily life, study, and work.

(2) Persons living together with the patients.

(3) Teachers and students attending the same class with the patients.

(4) Staff members caring for the patients at the same unit (e.g., office, workshop).

(5) Persons having dinner with the patients under poor ventilation systems.

(6) Relatives, friends, and colleagues of the patients who accompanied them to visit clinics or hospitals without appropriate precautions.

(7) Drivers who drove the patients without appropriate precautions.

(8) Healthcare workers without efficacious protection when caring for the patients.

(9) Persons who were with the patients in the same vehicle or elevator.

(10) Persons who directly provided food or entertainment for the patients.

(11) Other persons who were in close contact with the patients, which is determined by on-site epidemiological investigations. ${ }^{53}$

Whereas this definition allows the application of isolation and quarantine to be practically extended to anyone in the vicinity of the infected individual who does not live as a hermit or in solitary confinement, an unparalleled urgency applies to tracing and containing superspreaders before they come in contact with a disease carrier. Articulated within wider regimes of preparedness, the temporality allowed by this kind of epidemiological reasoning renders superspreaders an actionable biopolitical category. If we go back to Lloyd-Smith et al.'s letter to Nature, the implications become clear: "Disease control interventions could increase or decrease individual variation in infectiousness. Infected individuals might reduce their number of non-essential contacts, or governments might impose quarantine on particular individuals". ${ }^{54}$ According to this epidemiological reasoning, the 
predictive identification of "highly infectious individuals" can greatly increase the efficiency of disease control. ${ }^{55}$

The reduction of complex social relations to a single individual or human type and the application of regimes of preparedness on the latter are symptomatic of twenty-first-century epidemiology as a discipline inexorably entangled in the wider global, neoliberal political economy. Once we shift our focus from the nexus of socioeconomic relations and factors to the superspreader as an individual, public health attention and funding are due to be redirected toward the surveillance-preparedness complex discussed in detail in recent anthropological studies of biosecurity. ${ }^{56}$ Focusing on superspreaders rather than superspreading thus contributes to a shift of focus in public health policy that renders a problem of welfare into a problem of biosecurity. Two examples suffice to make this clear. If we consider the Amoy Gardens outbreak to be a result of bad sewage, a socioeconomic and infrastructural problem, we immediately position ourselves in the midst of questions of housing, planning, and the postcolonial/post-socialist political economy at large. If, on the other hand, the Amoy Gardens outbreak is interpreted in terms of an individual superspreader, then all of the above becomes superfluous, and what we need to do instead is to install early detection surveillance and sentinel systems and an apparatus of containment for biosocially dangerous individuals. Similarly, in the case of the Prince of Wales Hospital, if we see the outbreak as arising from lack of staff training, work-related stress, top-down managerial curtailment of health worker's control over healthcare, or underfunded hospital infrastructures, we find ourselves in the midst of questions of welfare, public spending, and relations of production in the hospital as a workplace. Whereas if we attribute the incident to a superspreader, then, once again, we may sideline all these complex issues and their political economic implications and focus on surveillance and control of individuated threats to global health. ${ }^{57}$ In other words, once we shift the focus from the complex material proximities of superspreading and the latter's social, political, and economic drivers to the superspreader as an exceptional individual or a bio-type, then public attention, care, and funding may be legitimately directed toward the biosecurity complex, leaving the neoliberal paradigm intact by excluding any discussion of the political economy and its impact on public health. In this sense, the superspreader must be seen, from a critical medical anthropological perspective, not simply as a convenient way out of the occasional modeling limitations of epidemiology but as a key figure in the consolidation of the shift from critical and welfare approaches to public health to a neoliberal biopolitical enclosure of life, health, and illness.

\section{Anti-Prometheus}

Let us then proceed by way of keeping in mind that while heterogeneous transmissibility is a significant concept in understanding infectious disease epidemics, both as an agent of contagion and as a contagious bio-type, the superspreader should be approached as a figure that, on the one hand, restricts materialist, social-relational, 
and political economic understandings of disease and, on the other hand, reduces contagion to a decontextualized transference of "germs" between individuals. ${ }^{58}$ In the succinct formulation of Jean-Luc Nancy, this entails a vision of sociality where "communication becomes contamination [and] transmission becomes contagion". 59

Should we then be content to conclude that the superspreader is a catalyst of neoliberal public health policy? Although this is indeed a pivotal biopolitical function of this epidemiological figure, here we need to return to the theoretical baseline of this study and consider the imaginary as something that relates not simply to the imitative, reproductive, and combinatory faculty of the imagination (i.e., what is imagined or imaginable) but to an institutive capacity, which lies beyond any distinction between the real and the fictional or the fictitious. ${ }^{60}$ That is to say, we need to proceed with an understanding of the imaginary not as something "that creates 'images' in the visual sense" - although, as Castoriadis notes, it does this too - but as what "creates forms" instead. ${ }^{61}$ Thus, understanding the figure of the superspreader would allow us to explore it as the mythic kernel of contemporary notions of pandemic contagion.

As a number of historical studies have shown, contagion is a notion that has been constitutive of modernity in its many transmutations over the past 200 years. ${ }^{62}$ From the original debates on contagionism and anti-contagionism in the course of the nineteenth century, and sociological or anthropological adoptions of the term by Gabriel Tarde or James Frazer, to its contemporary uses, contagion has reflected and fueled a series of political, social, and economic transformations. ${ }^{63}$ The word today is usually taken to mean human-to-human infection but it is also used, not metaphorically but quite laterally, to describe a wide range of events, such as financial crises and stock market collapse, revolutions, urban riots, terrorism, rumors, commercial trends, and the social media at large. ${ }^{64}$

Indeed, the study of contagion in recent years has led to path-breaking studies and to a wide expansion of our vision of the notion's implications for social, political, and economic life in today's world. While some studies have taken a more literary approach, focusing on narrative and exploring how contagion operates a metaphor or as "a heuristic tool or interpretive category" that has in turn "contaminated" a series of discourses, others have focused on biopolitical aspects of the proliferation and transformation of the notion in recent decades. ${ }^{65}$ Bridging the two approaches looms the question, as articulated by Andrew Lakoff, of what are the conditions of possibility for thinking about contagion in this way. ${ }^{66}$ The answer to this essentially Foucauldean aporia is, I would like to argue, mythic.

"Mythic" here refers not to myths as structured narratives or discourses. Rather, following Claude Lévi-Strauss, the term refers primarily to fragments and variants, or to be precise to the relations between them; more to the rules of permutation between myths than to the content of these myths in themselves. From this perspective, the mythic should not be seen as an adjective of the substantive myth, in the empirical sense of the term, but instead as a system of transformations that, in accordance with Lévi-Strauss' famous formula, determines the thought between myths. ${ }^{67}$ 
What does it then mean to say that the conditions of possibility for thinking about contagion in the way we do today are mythic in character? We need here to return to Walter Benjamin and his anthropological reception by Michael Taussig so as to note that to point at a mythic operation of contemporary phenomena is no less than to peer into the arcane heart of modernity. ${ }^{68}$ This is a gaze that may allow us not simply to decipher the irreducible irrationality of the reason of capital, the nation-state, or any of their particulars (development, social order, the liberal self, global health, etc.) but, more pertinently, to awaken into (and not from) the dream that structures modern life.

The reason why contagion is such a powerful way of thinking about phenomena ranging from Islamic terrorism to the 2008 financial collapse is because of a particular doxa of our societies. If connectivity and transmissibility are the cornerstones of globalized trade and digitally saturated capitalism, then in terms of its own criteria of success, contagion is a vital element of our neoliberal socioeconomic system. Insofar as becoming "viral" is key not only to the circulation of commodities and their images but also to the cultivation of capitalist forms of desire, the higher the "fever", the wider and faster the "catching on", the more profit and conformity are produced and reproduced. ${ }^{69}$ The ultimate form of this imperative, anthropologically speaking, is individuals desiring their own becomingviral and engaging in a constantly deferred, online activity to achieve this (think social media). Contagion in its contemporary form of "virality" can thus be said to be of central importance as a mythic operator of subjectivation in late capitalist societies.

Seen from the perspective of prescribed virality, the superspreader is not just a crucial component in "making something an emergency before it has become one" but is also indispensable as a figure that embodies a threshold of excess vis-à-vis our imagined civilizational achievement. ${ }^{70}$ For what is a superspreader, if not an uncanny embodiment and, at the same time, catalyst of global contagion? A figure that consummates our fantasy of becoming-viral by embodying the most authentic, original form of virality, the microbial one, and by doing so, becoming a threshold not between life and death but rather between human mastery and its demise? For, running the danger of repeating an already well-rehearsed argument in this book, this is what comes after the imaginary omni-superspreading event that ends up infecting humanity with a "killer virus": not the biological death of humanity but its ontological demise into a being stripped of its species-being. Hence, the superspreader must be seen as a figure that carries humankind through an existential threshold: not between existence and nonexistence but between an existence for mastery over human/nonhuman relations and an existence as an indistinct form of life in an interspecies field emptied of mastery. As we have already seen (Chapter 2), if through the next pandemic the field of interspecies existence is vacated of this quality, this is because what used to be mastered or masterable (human/ nonhuman relations) has ceased to be an intelligible and actionable field of relations. Undoubtedly, a recursive process is in place here: humans and nonhumans cease to be meaningfully different and thus human/nonhuman relations cease to be masterable, because human mastery has been rendered impossible in the first 
place. And vice versa, human mastery has become impossible precisely because humans and nonhumans have become indistinct.

It is to this uroboric existential implosion that the superspreader acts as a threshold. Yet, precisely because of the temptation to read this operation in messianic terms, it should be stressed that the figure of the superspreader does not carry with it an apocalyptic tone or potential. ${ }^{71}$ Instead, in order to isolate the mythic function of the superspreader, it is important to take seriously Paul Virilio's warning: "No one is waiting anymore for the revolution, only for the accident, the breakdown, that will reduce this unbearable chatter to silence". ${ }^{72}$ Revolutionary imaginaries in the course of the eighteenth, nineteenth, and twentieth centuries relied heavily on Promethean visions of humanity - not so much in the sense that critics of Marxism have advanced, as a struggle against nature (though this is clearly in place in the case of Engels-inspired Stalinism and Maoism), as in terms of envisioning the revolution as a liberation from nature, seen as the realm of "need". ${ }^{73}$ These visions drew on long-established mythic trajectories of the "culture hero". As will be examined in detail in Chapter 4, this is a figure that delivers humanity from its chains of ignorance or, otherwise, from a catastrophic event. It is no accident moreover that from among all culture heroes available to the West, it is Prometheus, in his Aeschylean form in particular, who has been most sought out by revolutionaries of all colors and creeds. ${ }^{74}$ In Greek mythology, the Titan stole fire (standing for techne) from the gods so as to give it to what may be best depicted as a genus of prehumans, described as living like ants in sunless caves. This allowed them to assume "culture" and come into their own as "creative" beings: "they who were like babies before they speak, [I made them] full of thought and endowed with thought capable of imposing itself on what exists". ${ }^{75}$ For giving humans this form of mastery, Prometheus was punished by Zeus, who bound him to the Caucasus so as to be tortured by a voracious, livereating eagle. Involving the defiance of power, its critique as a disease (nosos), the identification of becoming-human with becoming technically knowledgeable and skilled, and martyrdom in the hands of tyranny, from the mid-eighteenth century onward, the myth was adopted and adapted to the needs of different political movements across the globe. ${ }^{76}$ Translatable into a messianic vocabulary, the figure of Prometheus was a perfect fit for an age where humanity dwelled on desires of self-emancipation but also valorized suffering as a necessary ethical part of this political process. If, for good or for worse, this heroic age has today been eclipsed, as Virilio claims, by an imaginary that anticipates not the end of ignorance and tyranny or the dawn of a new and glorious era of human self-realization, but a meaningless end where nothing lies ahead, could we then say that the key to understanding the mythic function of the superspreader is the way in which it is underlined by anti-Promethean traits?

Let me try to elucidate this syllogism by means of a diagram (Fig. 3.1), where the relations in question may be clarified, albeit of course, as fellow anthropologists know all too well, at the expense of the mythopoetic richness of the different mythic variants of these two figures across space and time. The solid line in Figure 3.1 traces the Promethean myth. Having stolen fire (broadly speaking, 


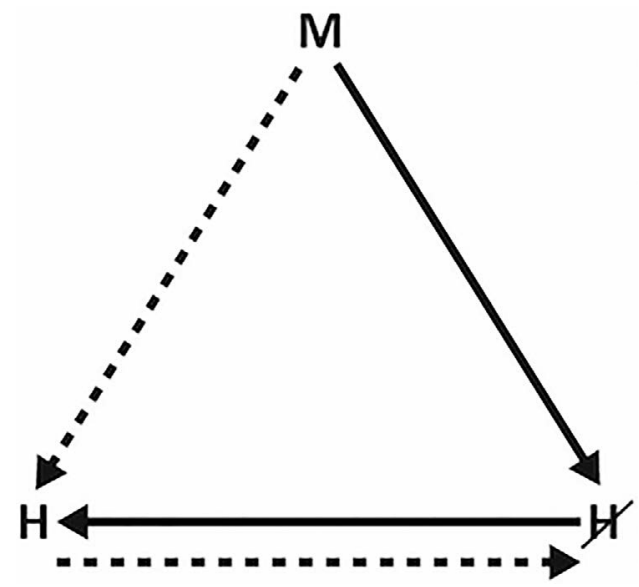

Figure 3.1 Diagram comparing Promethean and anti-Promethean transmission and transformation. Solid line follows Prometheus (M) giving techne and transforming nonhumans (crossed $\mathrm{H}$ ) to humans $(\mathrm{H})$. Broken line following superspreader $(\mathrm{M})$ giving a killer virus to humans $(\mathrm{H})$ and transforming them into nonhumans (crossed $\mathrm{H}$ ).

techne/mastery) from the gods, Prometheus (M) gives it to "nonhumans" (crossed $\mathrm{H})$ and transforms them into humanity proper $(\mathrm{H})$. The broken line in the same figure traces in turn the superspreader myth. Having contracted a virus from animals, the superspreader $(\mathrm{M})$ transmits it to humanity $(\mathrm{H})$, thus transforming its members into nonhumans (crossed $\mathrm{H})$.

This diagram can be thus transcribed into two mythic formulas:

$$
\begin{array}{ll}
\text { Prometheus } & \text { Superspreader } \\
\mathrm{M} \rightarrow \mathrm{H}=\mathrm{H} & \mathrm{M} \rightarrow \mathrm{H}=\mathrm{H}
\end{array}
$$

Lest I be accused of falling into a nostalgic trap for structural reversals, let it be noted here that this diagrammatic relation should be treated as a thought experiment, not as proof of some underlying human cognitive function. What this diagrammatic experiment allows us to see is an aspect of the superspreader that has generally remained overlooked in the medical humanities. What makes the superspreader figure specifically anti-Promethean is that from among the technae that the Titan gave to humanity, the greatest (to megiston) was healing. As stressed by Barbara Hughes Fowler, according to Aeschylus, this did not merely include skills for curing the mortals' bodies but, most importantly, skills for protecting their minds from a more dangerous "disease", the fear of their mortality, by means of "blind hopes" ${ }^{77}$ Castoriadis' commentary here is illuminating. Having himself taught humans that they are mortal, Prometheus' gift of "blind hopes" is praised by the Aeschylean chorus as "most useful". ${ }^{78}$ Castoriadis warns that this should not be seen as an ironic response. The truth that allows "human beings to emerge from 
a pre-human condition" is made operational only to the extent that humans can still act and create: "These two elements constitute anthropos, or at least ancient Greek anthropos: the knowledge of death and the potential of prattein/poiein, making-doing/creating, which this knowledge sharpens rather than stifles". ${ }^{79}$

In Prometheus Bound we thus stand before an anthropogenesis that is mythic not simply because it employs mythology but because "it answers the question concerning anthropos by turning to the source of his [or her] existence" - in other words, because it treats a question of essence as a question of origins. ${ }^{80}$ In doing so, it describes a sort of human being without or before humanity. This ontological state is most striking. It is not so much that prehumans live in caves but that they inhabit these sunless abodes "just as shapes in dreams" - beings "abandoned to chance". ${ }^{81}$ Castoriadis notes that the key notion here lies with Aeschylus' claim that these beings lived without discernment [gnomes]; they saw without seeing, heard without hearing, and so indeed, as Castoriadis notes, they remind us of zombies, at least as these are depicted in George Romero's filmography. ${ }^{82}$

Returning to our diagrammatic experiment, we can thus clearly see that it would be inaccurate to say that the nonhuman state out of which Prometheus helped humanity emerge was an "animal" state; the prehuman condition, as described by Aeschylus, occupies a zone that is neither human nor animal, insofar as the latter, in the Greek mind as in our own modern, naturalist ontology, can in no way be equated to mindless shadows but is endowed by its own intelligence. ${ }^{83}$ This then invites us to consider whether a similar qualification is due on the opposite pole of the diagram, in other words, as regards the impact of superspreaders on humankind. If the condition from which Prometheus salvaged humans through the gift of techne was more akin to the living dead than to animals, could we then say that, symmetrically, the superspreader delivers humanity to a similar state? Seen from this vantage point, the next pandemic threatens to render humans not only indistinct vis-à-vis the nonhuman, insofar as mastery is denied to them, but also deprived of the primitivist potential of rejoining the animal kingdom and its imaginary purity, vitality, or immanence, or reaching back to some Noble Savage kind of a Golden Age. In other words, the next pandemic as catalyzed by the superspreader marks not a return to nature (whether utopian or dystopian) but instead a double exclusion from both nature and culture (see Chapter 5).

It is important here to remember that this is the result of the superspreader involuntarily bearing the most advanced and desirable techne of modern being in excess: virality. And as a result, the reverse anthropogenesis brought about by the superspreader should be considered as anti-Promethean in yet another sense: in that what precipitates it is not an exogenous force or agency (a god or Titan) but humanity itself, through what institutes it in the first place: the technae of communication, trade, travel, technology, and so forth.

Thus, the superspreader is an anti-Promethean figure not only because it puts in place a reverse anthropogenesis but also because it embodies human extinction not as an act deriving from an extra-human realm but as a process of selfdestruction through self-realization. This sets the superspreader, anthropologically speaking, apart from what Castoriadis has analyzed as the mythic framework of 
Aeschylean anthropogenesis and closer to that of Sophoclean self-creation. ${ }^{84}$ For, Castoriadis explains, what separates the two classical tragic visions is precisely that in Sophocles (and his Antigone in particular) humanity's coming into itself is no longer portrayed as an extraneous act of divine or Titanic will but instead as an ontology of self-institution that bears with it always already the seeds of selfdestruction in the guise of hubris. ${ }^{85}$ Lacking self-limitation (literally in the form of not conforming to the established $\mathrm{R}_{0}$ ), the superspreader's virality can then be seen as the latest incarnation of this tragic reversal, where the greatest woe to the human race, following Antigone's famous stasimon, is confirmed to be humanity itself (Polla ta deina kouden anthropou deinoteron pelei).

\section{Mythic biopolitics}

This chapter has examined the double role of the superspreader as a figure that spans both the ideological and the mythological firmament of the pandemic imaginary. On the one hand, it is a figure that condenses and necessitates as a matter of urgency a shift away from the complexity of the social-relational and political economic field of disease transmission, instituting instead the individual as the focus of measures anticipating global contagion. As such, it forms the biopolitical ground for a disinvestment of social and infrastructural aspects of disease transmission and for the legitimation of neoliberal regimes of preparedness. On the other hand, the superspreader operates as a threshold between human and nonhuman modes of existence; a figure that by embodying the most desired state of being-human in late capitalism (virality) carries humanity "back" to a nonhuman realm where, stripped of its mastery, it stands indistinct to other species and yet dissimilar to them insofar as it inhabits more the space of an existential shadow than that of the immanence of life itself. In this sense, the superspreader forms a mythic figure whose function is anti-Promethean insofar as it returns humanity not to its biological origins as an animal-being but to its mythic origins as a nonbeing. This reversal is achieved not by the abandonment of the skills or knowledge that made us humans in the first place but by their excess, in the form of hyper-communication and hyper-connectedness embodied by the superspreader.

Caught between the biopolitical and the mythic, the superspreader, usually seen simply as a biological or at least epidemiological fact, occupies a privileged position in the pandemic imaginary - for this figure, literalized so effortlessly in actually existing individuals, does not simply contain two faculties: the one biopolitical, the other anthropogenic. Instead, it brings the two together in a unique and dynamic synergy. And it thus establishes the mythic foundations of neoliberal exceptionalism and the biopolitical grounds of extinction as a reversed anthropogenesis. With one hand, it transforms the excessive present into the anteroom of an erased future, while with the other hand it renders the end of the world into the basis for surrendering whatever is left of humanity and its relation to the world, after 300 years of capitalist plunder and alienation, to the urgency of preparing for an event that we can allegedly neither prevent nor survive as humans. 
As we will see in the next chapter, the implication of this is as simple as it is terrible: in order to subvive, humankind is urged to abandon its hopes of surviving with its humanity intact. A precautionary sacrifice is needed. One that will allow us, perhaps, to outlive the next pandemic, which is to mean to come out of it as something more than nonhuman - but only at the price of giving up here and now, that is to say in advance, what makes us human in the first place: our selfinstituting, autonomous agency and potential.

\section{Notes}

1 Anon., "Chinese Woman Dies from Suspected SARS on Moscow-Bound Train," Novosti, April 15, 2009, accessed May 12, 2013 http://en.ria.ru/world/20090415/121145477.html

2 Anon., "Suspected SARS Death on Russian Train Confirmed as Pneumonia," Novosti, April 16, 2009, accessed May 12, 2013 http://en.ria.ru/russia/20090416/121157796.html

3 Anon., "Mediki vuiyasnyat, popala li v Rossiyu atipochnaya pnevmoniya," BBC Russian.com, April 16, 2009, accessed May 12, 2013 http://news.bbc.co.uk/hi/russian/russia/ newsid_8001000/8001412.stm my translation.

4 Anon., "Chinese Embassy in Russia: The Death of the Woman Has Not Been Diagnosed with SARS," Flutrackers.com, April 15, 2009, accessed May 12, 2013 www. flutrackers.com/forum/showthread.php? $\mathrm{t}=99392$ \&page $=2$

5 Robert Peckham, "Infective Economies: Empire, Panic, and the Business of Disease," Journal of Imperial and Commonwealth History 41(2) (2013): 211-237.

6 See for example: Anon., "Chita Teenagers Not Suffering from Bird Flu," April 28, 2006, accessed 10 July, 2013 www.besttopnews.com/news/news/28-04-2006/22133-0/

7 Christos Lynteris, Ethnographic Plague: Configuring Disease on the Chinese-Russian Frontier (London: Palgrave Macmillan, 2016).

8 Stefan Lovgren, "The Mystery of the SARS Virus: How Is It Spread?," National Geographic News, April 9, 2003, accessed September 10, 2015 http://news.nationalgeographic.com/ news/2003/04/0409_030409_sars.html

9 James Gallagher, "Ebola 'Super-Spreaders' Cause Most Cases,” BBC News, February 14, 2017, accessed February 15, 2017 www.bbc.com/news/health-38955871

10 Christine Keller, Apocalypse Now and Then: A Feminist Guide to the End of the World (Boston: Beacon Press, 1996), 14. I am borrowing here the notion of "loss in the world" from Michaël Fœssel (2012); for further discussion, see Chapter 6.

$11 \mathrm{R}_{0}$ acquired cult status when it made the big screen in the blockbuster Hollywood film Contagion where Kate Winslet explained its meaning and implications to a group of sceptical public health officers. Scott Z. Burns, author of the film, considered this to be one of the film's greatest successes: "That one scene is really a science and math lesson, but people seem to get it"; Caleb Hellerman, "How 'Contagion' Spread to the Big Screen,” CNN, September 14, 2011, accessed September 9, 2017 http://edition. cnn.com/2011/09/13/health/contagion-big-screen/

12 Zhuang Shen, et al., "Superspreading SARS Events, Beijing, 2003," Emerging Infectious Diseases 10(2) (February 2004): 25-260. Interestingly, a search in Pubmed.gov produces only one article on superspeading and measles.

13 On the questions raised around $\mathrm{R}_{0}$, see: Romulus Breban, Raffaele Vardavas and Sally Blower, "Theory versus Data: How to Calculate $\mathrm{R}_{0}$ ?," PLoS One (March 2007) http:// dx.doi.org/10.1371/journal.pone.0000282; Matt J. Keeling and Bryan T. Grenfell, "Individual-Based Perspectives on $\mathrm{R}_{0}$," Journal of Theoretical Biology 203 (2000): 51-61; J. A. P. Heesterbeek and Klaus Dietz, "The Concept of $\mathrm{R}_{0}$ in Epidemic Theory," Statistica Neerlandica 50(1) (1996): 89-110; M. Heffernan, R. J. Smith and L. M. Wahl, "Perspectives on the Basic Reproductive Ratio," Journal of the Royal Society Interface 2(4) (2005): 281-293. 
14 Ping Chung Leung and Eng Eong Ooi, SARS War (Hong Kong: World Scientific Publications, 2003), 123.

15 Donald G. McNeil and Lawrence K. Altman, "How One Person Can Fuel an Epidemic," New York Times, April 15, 2003, accessed September 30, 2013 www.nytimes. com/2003/04/15/science/how-one-person-can-fuel-an-epidemic.html

16 Priscilla Wald, "Cultures and Carriers: 'Typhoid Mary' and the Science of Social Control,"Social Text 52/53 Queer Transexions of Race, Nation, and Gender (AutumnWinter, 1997): 181-214; Priscilla Wald, Contagious: Cultures, Carriers, and the Outbreak Narrative (Durham, NC: Duke University Press, 2008); Mary Mallon continues to function in works of medical fiction such as the TV Series The Knick (2014-2015) as a racialized figure of epidemic malice.

17 Wald, Contagious, 3; Richard A. Stein, "Super-Spreaders in Infectious Diseases," International Journal of Infectious Diseases 15 (2011): e510-e513.

18 The untori were supposed to be individuals involved in a conspiracy to spread plague in Milan in the 1620s; Romano Canosa, Tempo di peste: magistrate e untori nel 1630 a Milano (Rome: Sepere, 2000). Similar conspiracy theories regarding disease spreading, from early modern to contemporary times, have been extensively studied by historians and anthropologists: William G. Naphy, Plagues, Poisons and Potions: PlagueSpreading Conspiracies in the Western Alps c. 1530-1640 (Manchester: Manchester University Press, 2001); Ruth Rogaski, "Vampires in Plagueland: The Multiple Meanings of Weisheng in Manchuria," In Health and Hygiene in Chinese East Asia: Policies and Publics in the Long Twentieth Century, eds. Angela K. Ch. Leung and Charlotte Furth, pp. 132-159 (Durham, NC: Duke University Press, 2011); Luise White, Speaking with Vampires: Rumor and History in Colonial Africa (Berkeley, CA: University of California Press, 2000).

19 Wald, Contagious, 73; Paul Rabinow, Essays on the Anthropology of Reason (Princeton: Princeton University Press, 1996). This does not mean that people deemed to be superspreaders have not fallen victim to accusatory practices. Wald (2008) has underlined the scapegoating effect on those accused of being hyper-infective, noting that labeling patients or carriers as superspreaders can have devastating effects on their lives. Esther Mok, for example, a 26-year-old former flight attendant, who was blamed spreading SARS to 133 individuals in 2003, was reported to have suffered extensively even after her recovery; fearing the reaction by the media, Singapore's authorities consigned the supposed superspreader to "in a modern-day exile" at the specially designated SARS hospital of the city (Flemming 2003). Characteristically, Lim Hng Kiang, Singapore's Health Minister at the time, stated in defence of the decision: "Esther Mok infected the whole lot of us" (Laurance 2003). However, it is worth noting that in the long term the story of Esther Mok also attracted at least a trickle of popular sympathy in Singapore with the comparison between her and Esther Tan, a Mt Everest climber, becoming the basis of a small-circulation movie titled A Tale of Two Esthers (Fong 2015) more than ten years later.

20 Wald, Contagious, 4.

21 Anon., "Germ Warfare," Post Magazine, December 1, 2013, 21.

22 Christopher R. Braden, et al., "Progress in Global Surveillance and Response Capacity 10 Years after Severe Acute Respiratory Syndrome," Emerging Infectious Diseases 16(6) (2013): 864-869.

23 WHO Department of Communicable Disease Surveillance and Response, Consensus Document on the Epidemiology of Severe Acute Respiratory Syndrome (SARS) Produced by the Severe Acute Respiratory Syndrome (SARS) Epidemiology Working Group and the Participants at the Global Meeting on the Epidemiology of SARS, May 16-17, 2003 www.who.int/csr/sars/en/WHOconsensus.pdf; Zhuang, et al., "Superspreading SARS Events," 25. This trade metaphor seems to validate Robert Peckham's theory of a crossover between epidemiological and financial discourse (2013).

24 Zhuang, et al., "Superspreading SARS Events," 23. 
25 Dennis Normille, “Understanding the Enemy,” Science 339 (March 15, 2013): 1272.

26 Ali Khan and William Patrick, The Next Pandemic: On the Front Lines against Humankind's Gravest Dangers (New York: PublicAffairs, 2016), 176.

27 Wald, Contagious, 10.

28 See especially papers in "Epidemic Events and Processes" special section Cambridge Anthropology, ed. Christos Lynteris (2014).

29 For an introduction to syndemic theory, see: Merrill Singer, Introduction to Syndemics: A Critical Systems Approach to Public and Community Health (San Francisco: JosseyBass, 2009). On epidemics and dramaturgy, see: Charles E. Rosenberg, "What Is an Epidemic? AIDS in Historical Perspective," Daedalus 118(2) Living with Aids (Spring 1989): 1-17.

30 Miriam Falco, "New SARS-Like Virus Poses Medical Mystery," CNN, September 24, 2012, accessed December 5, 2013 http://thechart.blogs.cnn.com/2012/09/24/new-sarslike-virus-poses-medical-mystery/

31 Helen Branswell, "Superspreaders' Could Turn New Coronavirus into SARS-Like Event: Experts," The Canadian Press, March 25, 2013, accessed October 1, 2013 www.ctvnews.ca/health/superspreaders-could-turn-new-coronavirus-into-sars-likeevent-experts-1.1210070

32 Branswell, "'Superspreaders' Could Turn New Coronavirus into SARS-Like Event: Experts."

33 Branswell, "'Superspreaders' Could Turn New Coronavirus into SARS-Like Event: Experts."

34 James O. Lloyd-Smith, et al., "Superspreading and the Effect of Individual Variation on Disease Emergence," Nature 438(17) (November 2005): 355.

35 Lloyd-Smith, et al., "Superspreading and the Effect of Individual Variation on Disease Emergence," 355.

36 Lloyd-Smith, et al., "Superspreading and the Effect of Individual Variation on Disease Emergence", 355.

37 Lloyd-Smith, et al., "Superspreading and the Effect of Individual Variation on Disease Emergence," 355.

38 Lloyd-Smith, et al., "Superspreading and the Effect of Individual Variation on Disease Emergence," 357.

39 Sarah Yang, "Small Groups of Superspreaders Lead Most Infections, New Study Says," UC Berkeley Press Release, November 16, 2005, accessed November 11, 2015 www.berkeley.edu/news/media/releases/2005/11/16_super.shtml

40 Getz in Yang, "Small Groups of Superspreaders Lead Most Infections, New Study Says."

41 Yang, "Small Groups of Superspreaders Lead Most Infections, New Study Says."

42 Zhuang, et al., "Superspreading SARS Events," 258.

43 Zhuang, et al., "Superspreading SARS Events,"258.

44 Hannah Brown and Ann H. Kelly, "Material Proximities and Hotspots: Toward an Anthropology of Viral Hemorrhagic Fevers," Medical Anthropology Quarterly 28(2) (2014): 280-303; Max S. Y. Lau, et al., "Spatial and Temporal Dynamics of Superspreading Events in the 2014-2015 West Africa Ebola Epidemic," Proceedings of the National Academy of Sciences of the United States of America 114(9) (February 2017): 2337-2342.

45 WHO Department of Communicable Disease Surveillance and Response, Consensus Document on the Epidemiology of Severe Acute Respiratory Syndrome (SARS).

46 WHO Department of Communicable Disease Surveillance and Response, Consensus Document on the Epidemiology of Severe Acute Respiratory Syndrome (SARS).

47 WHO Department of Communicable Disease Surveillance and Response, Consensus Document on the Epidemiology of Severe Acute Respiratory Syndrome (SARS).

48 Stein, "Super-Spreaders in Infectious Diseases," e511.

49 Y. Li, S. Duan, I. T. S. Yu and W. Wong, "Multi-Zone Modelling of Probable SARS Virus Transmission by Airflow between Flats in Block E, Amoy Gardens," Indoor Air 15 (2004): 96-111. 
50 Mary Ann Benitez, "Scientists Revisit Outbreak Hospitals," South China Morning Post, March 2, 2005, accessed November 10, 2013 www.scmp.com/article/490922/ scientists-revisit-outbreak-hospitals

51 Barry R. Bloom, "Lessons from SARS," Science 300 (May 2, 2003): 701; Margaret Chan, "The Lessons of SARS, 10 Years On," South China Morning Post, February 20, 2013, accessed November 23, 2013 www.scmp.com/comment/insight-opinion/article/1154055/ lessons-sars-10-years; Michael Smith, "SARS Lessons: Stay Alert for Emerging Pathogens," MedPageToday, April 22, 2013, accessed November 10, 2013 www.medpagetoday. com/InfectiousDisease/Surveillance/38611

52 Katherine A. Mason, Infectious Change: Reinventing Chinese Public Health after an Epidemic (Stanford, CA: Stanford University Press, 2016).

53 Chinese Medical Association, "Consensus for the Management of Severe Acute Respiratory Syndrome," The Chinese Medical Journal 116(11) (November 2003), 1632.

54 Lloyd-Smith, et al. "Superspreading and the Effect of Individual Variation on Disease Emergence," 357.

55 Lloyd-Smith, et al. "Superspreading and the Effect of Individual Variation on Disease Emergence," 358.

56 See Chapter 2 for discussion and bibliography.

57 For a discussion of faulty infrastructure as resulting in superspreading events in the course of the MERS outbreak in South Korea, see: Kai Kupferschmidt, "Did Poor Ventilation Lead to MERS 'Superspread' in Korea?," Science Magazine (June 5, 2015), doi:10.1126/science.aac6802; Nishiura, et al., "Identifying Determinants of Heterogeneous Transmission Dynamics of the Middle East Respiratory Syndrome (MERS) Outbreak in the Republic of Korea, 2015: A Retrospective Epidemiological Analysis," British Medical Journal Open 2016 doi:10.1136/bmjopen-2015-009936. In Nishiura et al. (2016) we also find a typological reduction of infrastructural and political economic factors into the diptych of "procedural/mechanical" factors.

58 Steve Hinchliffe, et al., "Biosecurity and the Topologies of Infected Life: From Borderlines to Borderlands," Transactions of the Institute of British Geographers 38(4) (October 2013): 531-543.

59 Jean-Luc Nancy, After Fukushima: The Equivalence of Catastrophes (New York: Fordham University Press, 2015), 34.

60 Cornelius Castoriadis, Fait et a faire; Les carrefours du labyrinthe, Vol. 5 (Paris: Seuil, 1997).

61 Castoriadis, Fait et a faire, 271, my translation.

62 Alishon Bashford and Claire Hooker (eds.), Contagion: Historical and Cultural Studies (London and New York: Routledge, 2014); Mark Harrison, Contagion: How Commerce Has Spread Disease (New Haven: Yale University Press, 2012); Nayan Shah, Contagious Divides: Epidemics and Race in San Francisco's Chinatown (Berkeley, CA: University of California Press, 2001); Peter Stallybrass and Allon White, "The City: The Sewer, the Gaze and the Contaminating Touch." In Beyond the Body Proper: Reading the Anthropology of Material Life, eds. Judith Farquhar and Margaret Lock, pp. 266-286 (Durham, NC: Duke University Press, 2007); Allan C. Christensen, Nineteenth-Century Narratives of Contagion: 'Our Feverish Contact' (London and New York: Routledge, 2005).

63 Erwin H. Ackerknecht, "Anticontagionism between 1821 and 1867, the Fielding H. Garrison Lecture," International Journal of Epidemiology 38 (2009): 7-21; Tony D. Sampson, Virality: Contagion Theory in the Age of Networks (Minneapolis: Minnesota University Press, 2012). See also: Alexandra Minna Stern and Howard Markel, "Commentary: Disease Etiology and Political Ideology: Revisiting Erwin H Ackerknecht's Classic 1948 Essay, 'Anticontagionism between 1821 and 1867'," International Journal of Epidemiology 38(1) (February 1, 2009): 31-33. 
64 Robert Peckham, "Infective Economies: Empire, Panic and the Business of Disease," The Journal of Imperial and Commonwealth History 41(2) (April 2013): 211-237; S. Harris Ali and Roger Keil (eds.), Networked Disease: Emerging Infections in the Global City (Oxford: Blackwell Publishers, 2008); Charles Briggs, "Pressing Plagues: On the Mediated Communicability of Virtual Epidemics," In Plagues and Epidemics: Infected Spaces Past and Present, eds. D. Ann Herring and Alan C. Swedlund, pp. 39-60 (Oxford: Berg, 2010); Kari Nixon and Lorenzo Servitje (eds.), Endemic: Essays in Contagion Theory (London: Palgrave Macmillan, 2016); Wald, Contagious.

65 Bruce Magnusson and Zahi A. Zalloua, "Introduction: The Hydra of Contagion," In Contagion: Health, Fear Sovereignty, eds. Bruce Magnusson and Zahi A. Zalloua, pp. 3-24 (Seattle: University of Washington Press, 2012), 4. Besides the classic works of Sontag (2009) and Treichler (1987), for a recent study of contagion as metaphor, see: Peta Mitchell, Contagious Metaphor (London: Bloomsbury, 2012). For critiques of the limitations of this metaphorical approach, see: Christos Lynteris and Nicholas H. Evans, "Introduction: The Challenge of the Epidemic Corpse," In Histories of PostMortem Contagion: Infectious Corpses and Contested Burials, eds. Christos Lynteris and Nicholas H. Evans, pp. 1-25 (London: Palgrave Macmillan, 2018); Florent Coste, Adrien Minard and Aurélien Robert, "Contagions. Histoires de la précarité humaine," Tracés. Revue de Sciences humaines 21 (2011): 7-20.

66 Andrew Lakoff, "Toward a Genealogy of Global Health Security," In Contagion: Health, Fear Sovereignty, eds. Bruce Magnusson and Zahi A. Zalloua, pp. 44-70 (Seattle: University of Washington Press, 2012).

67 Frédéric Keck, Claude Lévi-Strauss, une introduction (Paris: Pocket, 2011).

68 See in particular the collection of essays in: Michael Taussig, Walter Benjamin's Grave (Chicago: The University of Chicago Press, 2006); for a discussion of Taussig's Benjamin and the magic of modernity, see: Christos Lynteris, "The Frankfurt School, Critical Theory and Anthropology," In Schools and Styles of Anthropological Theory, ed. Matei Candea (London and New York: Routledge, 2018).

69 For a bestselling manifesto of virality, see: Jonah Berger, Contagious: Why Things Catch On (New York and London: Simon \& Schuster, 2013).

70 Geoffrey Whitehall, "The Aesthetic Emergency: The Avian Flu Effect," In Contagion: Health, Fear Sovereignty, eds. Bruce Magnusson and Zahi A. Zalloua, pp. 71-98 (Seattle: University of Washington Press, 2012), 72.

71 If, as Whitehall (2012) has underlined, regimes of pandemic emergency configure our temporal being as one in which the next pandemic is "overdue", a living "on borrowed time", it is indeed tempting to say that the superspreader is in turn a figure that accelerates the time of contagion, bringing about human extinction. This perhaps is the only messianic element we can trace back to the superspreader. For a discussion of the relation between apocalyptic tones and apocalyptic events, see: Martin Jay, "The Apocalyptic Imagination and the Inability to Mourn," In Rethinking Imagination: Culture and Creativity, eds. G. Robinson and J. F. Rundell, pp. 30-47 (London and New York: Routledge, 1994). On the non-apocalyptic nature of the next pandemic, see Chapter 1.

72 Whitehall, "The Aesthetic Emergency," 87; Paul Virilio, Art and Fear (London: Continuum, 2004), 75. For a discussion of whether catastrophe has taken the place of the revolution in contemporary societies, see: Michaël Fœssel, et al., "La catastrophe estelle une politique?," Esprit 374(5) (May 2011): 54-70.

73 For a critique of the identification of Marx's thought as "Promethean" in the contra natura sense of the term, see: Walt Sheasby, "Anti-Prometheus, Post-Marx: The Real and the Myth in Green Theory," Organization \& Environment 12(1) (March 1999): 5-44.

74 As Raggio (1958: 44) has pointed out, before the mid-eighteenth century Prometheus was seen from a more Hesiodic perspective, as marking the end of a Golden Age of humanity: "the destroyer of a happy original state". As several scholars have explored, 
in Hesiod Prometheus is less of a rebel and more of a trickster figure (Kerényi 1997; Beall 1991; Hustis 2003).

75 Aeschylus, Prometheus Bound (443-44) - translation in: Cornelius Castoriadis, Figures of the Thinkable, translated by Helen Arnold (Stanford, CA: Stanford University Press, 2007), 6.

76 It may be noted here that, following Mossman (1996), the tortures imposed by Zeus were meant to animalize Prometheus. On the importance of nosological notions in Prometheus, see: Andrew Karp, "The Disease of Inflexibility in Aeschylus' 'Prometheus Bound"', Mediterranean Studies 6 (1996): 1-12.

77 Aeschylus, Prometheus Bound, line 250; B. Hughes Fowler, "The Imagery of the Prometheus Bound," The American Journal of Philology 78(2) (1957): 173-184; see also: Mossman (1996: 64) on the imagery of sickness in Prometheus Bound and Prometheus being "a doctor unable to heal himself". Line 248 of Aeschylus' Prometheus Bound is often mistranslated as Prometheus stating that he had saved humans from foreseeing death, when in fact they read: "I put an end, for mortals, to the non-foreseeing of death"; for discussion of this translation, see: Castoriadis, Figures of the Thinkable, 9-10.

78 Castoriadis, Figures of the Thinkable.

79 Castoriadis, Figures of the Thinkable, 10.

80 Castoriadis, Figures of the Thinkable, 5.

81 Aeschylus, Prometheus Bound.

82 Castoriadis, Figures of the Thinkable, 5. For fuller discussion of zombies in the pandemic imaginary, see Chapter 4.

83 A look at Aelian's On Animals provides a kaleidoscopic vision of the latter well into the Roman third century.

84 Castoriadis, Figures of the Thinkable. On Aeschylus' and Sophocles' anthropogeny according to Castoriadis see also: Cornelius Castoriadis, "L'anthropogonie chez Eschyle et chez Sophocle," In La Grèce pour penser l'avenir, eds. Marc Augé, et al., pp. 151-172 (Paris: L'Harmattan, 2000).

85 And not, as Michael Fischer (2009: xv) reads it, merely "a drive, a compulsion of self-fashioning." 


\section{The epidemiologist as culture hero}

An anticipated event leading to human extinction, the next pandemic has in the last two decades assumed the role of a central existential risk, weaving around it complex mythocosmological forms and practices. As an end of the world variant, the next pandemic necessitates its very own culture hero. This twenty-first-century Gilgamesh is none other than the epidemiologist. In this chapter, I will examine the emergence of this figure in recent years, and in particular how it has come to populate the growing genre of films about infectious disease pandemics. Rather than rehearsing an apocalyptic fantasy, I will argue that what these pandemic films reflect and propagate to mass audiences is a new definition of humanity and the way in which this is to be preserved in the face of pandemic-borne existential risk. Central to this operation is the representation of the epidemiologist as a mirror and catalyst of human sociality, a new visual form that may be singled out as a significant operator in the pandemic imaginary.

My intention is to provide an anthropological analysis that will help us understand the ways in which, through the lens of this prolific cinematic genre, humanity is instituted and negotiated on the imagined crux of extinction - an end of the world event whose prepared anticipation revolves around the transformation of human sociality. In my analysis of this "culture hero" image and its implications, I would like to draw away from the classic anthropological analysis developed in the 1960 s by Barbara Myerhoff and William Larson. ${ }^{1}$ Following the latter, physicians were rendered culture heroes in post-Second World War American television dramas through a process that, on the one hand, stripped them from their charisma by means of routinization, while, on the other hand, transformed them into someone who "structures and defines the ingredients of typical situations, depicting appropriate behaviors, and accompanying motivations and interpretations". ${ }^{2}$ In their 1965 paper and subsequent work, the two anthropologists followed Orrin Klapp's sociological analysis in theorizing the doctor-as-culture hero as a figure who generates social control and integration in an otherwise heterogeneous and fragmented post-traditional society. ${ }^{3}$ No longer a charismatic hero or a catalyst of social change, the physician is, according to this analysis, able to foster social cohesion by means of his or her technical training and skill and not due to some innate qualities that are transferred to the realm of science and technology as such. ${ }^{4}$ The difference between Myeroff and Larson's doctors 
and twenty-first-century on-screen epidemiologists lies in the fact that what constitutes the latter as culture heroes is not their ability to generate social consensus in the midst of crisis. It is rather their propensity to embody and thus restore humanity, which under the given pandemic scenario is positioned ontologically on the brink of extinction. I would hence like to argue that, under the bane of the next pandemic, the epidemiologist is rendered a culture hero in the classical sense of the term: a mythic figure that "makes human society possible", under the condition that humanity embraces the neoliberal governmental principle of self-limitation as a biopolitical necessity vis-à-vis the cataclysmic force of the "killer virus". 5

\section{Time and human sociality}

Since the emergence of "coming plague" scenarios in epidemiological and popularmedicine discourse in the early 1990s, Hollywood movies have become an exemplary terrain for the constitution of the epidemiologist as culture hero. Previously, infectious disease epidemics were an unusual subject for Hollywood films, so, with the exception of Panic in the Streets (1950), The Satan Bug (1965), and The Andromeda Strain (1971), we may say that the theme was the privileged field of European art cinema, with striking examples including masterpieces such as Ingmar Bergman's The Seventh Seal (1957), Luchino Visconti's Death in Venice (1971), and Lars von Trier's Epidemic (1987). These films show little or no interest in epidemiological aspects of infectious disease outbreaks and no epidemiologist is featured in them. The disease, usually modeled upon popular perceptions of bubonic plague, is instead used as a powerful context for the unfolding of an existential drama, a technique following Albert Camus' influential novel, The Plague (1947).

It is hence in Wolfgang Petersen's film Outbreak (1995) that we first come across the epidemiologist as culture hero on the big screen. The character in question is Sam Daniels (Dustin Hoffman), a virologist and colonel of the United States Army Medical Research Institute of Infectious Diseases (USAMRIID). The film begins with a black screen featuring a foreboding quote by biologist and Nobel laureate Joshua Lederberg, which has become a mantra of the pandemic imaginary: "The single biggest threat to man's continued dominance on the planet is the virus". The opening scene of the movie takes us to the Congo Basin. The plot unfolds as a prototype of what we may call the first "African phase" of emerging infectious diseases discourse. This corresponded to the mid-1990s fears that the next pandemic would arise from sub-Saharan (the silent operator here being "tropical") Africa, usually due to unwarranted animal to human contact, and would assume a hemorrhagic form of "organ melting" proportions, like the Ebolavirus of Richard Preston's pathologically misleading narrative The Hot Zone. ${ }^{6}$ As Kirsten Ostherr has noted in her pioneering study on cinematic representations of contagion, the film is heavily based on "the emergence of Ebola into the popular discourse of contagion in the Unites States", exemplified in the writings of Preston, while also reproducing highly racialized and homophobic approaches to AIDS. ${ }^{7}$ 
The first scene of the film depicts the outbreak of a lethal and mysterious disease in a mercenary camp, which is eventually bombed to oblivion by the US Army in order to contain the outbreak. This African prelude of the main film is punctuated by scenes of monkeys running in the periphery of the camp, before and after its destruction. As Ostherr notes, the most striking moment in this sequence is when

the camera again cuts [. . . ] to a medium-shot of a screeching monkey, then dissolves into a smoky mist to a close-up of the witch doctor's [sic] face, thus creating a visual metonymy linking monkey, black skin, and African 'premodernity' as the vectors of an uncivilized and deadly contagion. ${ }^{8}$

The disease is thus constructed from the very start of the film as both primeval and emerging, embodying two aspects of the unknown in a manner reminiscent of popular narratives about the origins of HIV/AIDS, either as a "primitive" apeto-man (sexually transmitted?) infection or as a high-tech laboratory-produced pathogen. Faced with such a dark and elusive enemy, Colonel Daniels' heroic fit consists in dedicating himself to the pivotal epidemiological task overlooked by his superiors: tracing the zoonotic host, a monkey that, captured and imported to the USA from Zaire, smuggles with it the hemorrhagic virus, "Motaba", a fictional, "phallically anthropomorphized" version of Ebola. ${ }^{9}$

Although the film is arguably more about corruption and military conspiracy than about epidemiology, it is the first Hollywood movie to tackle zoonosis and disease emergence and to introduce the general public to basic epidemiological notions such as contact tracing. In the end, Colonel Daniels' prioritization of civil and medical duty over military obedience averts a mini-Hiroshima event in North California (the Army command wants to liquefy the epicenter fictional town of Cedar Creek with all its inhabitants) and produces a serum, saving humankind from viral-borne extinction. In this sense, Colonel Daniels embodies a variant of the classic Hollywood maverick hero, who, as Adato Kiku has argued, works for humanity against corrupt state institutions. ${ }^{10}$ What sets this visual narrative apart, however, is the temporality in which the hero operates.

What makes Colonel Daniels unique is his "real time" reaction, his ability to trace the host, isolate the mutant virus, and produce the life-saving antiserum before the disease spreads. ${ }^{11}$ The importance of this is underlined through the castigation of his superior, Brigadier General Ford (Morgan Freeman), who delays the distribution of the original serum before the virus mutates. Delay, broadly understood as a time lag, is the enemy of the epidemiologist who is a culture hero only insofar as he works in and against time, striving to save the future by seeking the past in the present. This interlaced temporality, a quest for past origins in present time so as to guarantee the future of humanity, is crucial to the constitution of epidemiological heroics and will assume greater complexity and importance in later variants of the epidemiologist as cultural hero, such as Steven Sodenbergh's film Contagion (2011).

In contrast to Outbreak, Contagion is not a protagonist-led movie but rather comprises interconnected snippets of life stories during the pandemic. The culture 
hero in place is thus collective rather than individual, composed by a triangle between three female epidemiologists. On the one hand, we have Centers for Disease Control and Prevention (CDC) epidemiologist Dr. Ally Hextall (Jennifer Ehle) who discovers the genetic drift event that lies at the root of the killer virus: a bat-to-pig jump, which leads her to pronounce the key phrase of the film: "somewhere in the world the wrong pig met the wrong bat". More than this, however, Dr. Hextall uses the discovery made by a precursor character, University of California San Francisco professor Dr. Ian Sussman (Elliott Gould), so as to manufacture a vaccine. The key heroic element here, as in Outbreak, is putting civil and medical duty above orders. In the face of CDC failure to procure satisfactory results, Dr. Sussman is able to develop a cell culture where the new virus, meningoencephalitis virus one (MEV-1), can grow. Dr. Sussman does this by disobeying orders by the CDC deputy director to destroy his working samples of the virus, after testing is cleared only for Biosafety Lab Level 4. Taking the lead of disobedience from the professor and adopting his critique of the slowness of staterun lab processes, Dr. Hextall achieves culture hero status by breaking the rules in an even more radical way, without however turning against her home institution as such or assuming the role of the maverick hero described by Kiku. ${ }^{12}$ A key scene in the film depicts the epidemiologist in full biohazard airtight suit, facing a single surviving experimental rhesus monkey in its cage. This is a silent, protracted moment of face-to-face evolutionary contemplation, where the gift from the past (the monkey's acquired immunity) of a future for humankind (species survival) is rendered actionable by the presence of the culture hero. Acting as an intermediary between humankind's evolutionary past and its future survival, Dr. Hextall proceeds to use the experimental vaccine secretly on herself, refusing to go through protocol, ethical clearance, and all the "time-wasting" procedures of human subject testing. She then rushes to the hospital where her father lies ill in bed, infected by the virus; she removes her mask, talks to him, explaining what she is doing, and finally kisses him on the forehead so as to test the efficacy of the vaccine. Dr. Hextall thus again embodies the role of an intermediary, this time between the present infected humanity and the promise of a healthy future while upholding kinship as a fundamental principle of human sociality. The test proves successful and vaccine production begins.

The second figure in the triangle is the CDC epidemiological intelligence (EIS) officer Dr. Erin Mears (Kate Winslet) who goes to the epicenter of the outbreak in Minnesota to collect information while engaging in a tag-of-war battle with procrastinating state-level public health bureaucrats in order to secure in-time resources. In the course of her fieldwork, Dr. Mears is infected and succumbs to the disease. The role of Dr. Mears embodies epidemiological heroics at their crudest, self-sacrificial form. In the words of the actress, who "spent time at the CDC and met with past and present EIS officers" in preparation of her role in the film". ${ }^{13}$ "These are people who can be sent into war zones where there's been an outbreak of a new virus. Fear is not an option. If they feel it, they learn to push it aside". ${ }^{14}$ Like Dr. Hextall, albeit with a more martyrological angle, Dr. Mears also embodies the intermediary role of the culture hero, as she mediates between 
both the scientific community and the common people, and between the latter and local bureaucrats.

The third figure of the heroic triangle is Dr. Leonora Orantes (Marion Cotillard), a WHO epidemiologist dispatched to Hong Kong to trace the source of the virus. There, she manages to identify patient zero (the first infected individual with symptoms of the disease), by "working backwards in time to unravel the mystery of where this thing came from". ${ }^{15}$ During her work, she is kidnapped by a Chinese assistant, who keeps her hostage in a village, negotiating her release in exchange of the vaccine. When the exchange actually occurs, Dr. Orantes finds out that the vaccine provided for her kidnappers and their village community is only a placebo; she immediately dumps her treacherous WHO rescuer so as to return to the countryside to warn the villagers. Dr. Orantes thus embodies the intermediary between the scientific community and the common people, but also the "fighter against time", leaving no doubt that here "time" rather than other human beings (including her own captors) "is the enemy". ${ }^{16}$

It is clear that the three characters of the film form a triangular paradigm of selflessness and self-sacrifice; yet this is not the crucial point here. The epidemiologist does not simply replicate the twentieth-century doctor-hero, who dedicates her highly specialized skills and her very life to battling disease so as to save smaller or larger portions of humanity. Rather, what is important here is that the three heroes remain social when social bonds around them collapse, rehearsing the broader scenario of anomy, which we have already examined in Chapter 1. We need to remember here that from Thucydides' description of the "plague" of Athens to Giovanni Boccaccio's Decameron account of plague in Medieval Florence and Antonin Artaud's influential essay The Theatre and the Plague, the time of plague is configured as essentially Saturnalian: "the last of the living are in frenzy: the obedient and virtuous son kills his father; the chaste man performs sodomy upon his neighbours". ${ }^{17}$ This is not simply a situation where organized society is brought to its knees, with the police, the post office, and the healthcare system tattering, but where anomy becomes an ontological threshold: a time where the social nature of humankind is at risk and, at the same time, at the brink of a radical metamorphosis. As, from the perspective of the political economical principles reproduced by the particular cultural industry, sociality is primarily a relation of exchange, it is no surprise that in Hollywood films societal collapse is usually portrayed through looting or supermarket ransacking. With exchange, the cornerstone of neoliberal sociality having collapsed, humankind is returned to the reign of use value; a condition that, contra Artaud, in the late-capitalist pandemic imaginary is not envisioned as ecstatic, revolutionary, or purifying but as a cruel and relentless process of ontological perdition. ${ }^{18}$

In the midst of this devolution of human sociality, where the mentality of each for her own prevails, the epidemiologist shines as a last beacon of humanity in her stubborn sociality. In the darkest hour, where the "horror in our backyard" has brought about a collapse of the distinction between what is good and what is useful (to remember Thucydides), the culture hero rescues humanity from oblivion by upholding nothing less than the principle of exchange. ${ }^{19}$ When, at the 
end of the film, Dr. Orantes returns to her captors to warn them of the counterfeit vaccines they received in exchange of her by the WHO, we need to see this not so much as an all-consuming act of humanness, as love for the children she taught while being hostage in the Chinese village, nor as a manifestation of the Stockholm Syndrome, but as a refusal of the epidemiologist to be exchanged for nothing - an act aimed at upholding the principle of exchange (life for life) and, more than that, exchange as the constituting principle of human sociality, even at the twilight of human existence as such. No wonder Dr. Orantes looses her speech once she takes up her moral task in Hong Kong's airport: she has assumed the role of an offended commodity and, though perfectly able to act, commodities must necessarily remain mute, for the only thing they need to annunciate is immanent in their being-for-exchange.

\section{Screen heroics off-screen}

Admittedly less outspoken as regards the wider political economic subtext of the outbreak narrative, a recent presentation by the (now ex-) director of the US CDC Office of Public Health Preparedness and Response at the annual multimedia science fiction festival Dragon*Con is nonetheless revealing of the pertinence of the cinematic image of the epidemiologist in the off-screen world. Appearing on Labor Day 2011, Dr. Ali S. Khan told an eager audience that "Mother Nature is much more creative than we are", it, rather than bioterrorism, being the most likely source of a global pandemic. ${ }^{20}$ This statement seems to be a moment of real-life replicating $\operatorname{art}^{21}$ - for it brings to mind the emergency meeting in Contagion, where, being asked whether the pandemic may be the result of weaponized avian flu by rogue enemies, the fictional deputy director of the CDC responds: "Someone doesn't have to weaponize the bird flu, the birds are doing that". The epidemiologist is thus portrayed as engaged in a struggle not against an extraterrestrial or human-made event, as in more traditional versions of biological threat like the Day of the Triffids (1963), The Andromeda Strain, The Stand (1994), Twelve Monkeys (1995) or Rise of the Planet of the Apes (2011), but against nature itself. ${ }^{22}$ His or her role in the struggle for the survival of humanity, as a being-formastery, is one of the culture hero in the most classic, dichotomous sense of the term: a mediator between nature and culture.

This symbolic form looms large in media reporting of the CDC PR stunt at the Dragon*Con festival:

After speaking with a few people following the panel, Khan leaves Dragon*Con as silently as he came. Around him, people are dressed to fight imaginary dragons, ghosts, demons, and wraiths, but Khan fights the real monsters - public health emergencies like pandemic influenza, outbreaks of cholera and Ebola, and the aftermath of natural disasters. Unlike the heroes of science fiction, his work does not end. ${ }^{23}$

There is no mistake here. Forget Superman and Batman; hijacking the old leftist slogan, we may proclaim: epidemiologists are the real heroes. It is not just that 
they are skilled, efficient, and humble but more importantly that they endure. One should pay close attention to the final phrase of the journalistic piece on epidemiological heroism: "Unlike heroes of science fiction, his work does not end". ${ }^{24}$ Given the importance of time in the construction of the epidemiologist as culture hero, the statement is of vital importance. It poses the epidemiologist as metonymically encapsulating the temporality of epidemics, as discussed by Elana Gomel: "Instead of delivering the climactic moment of the Last Judgment, pestilence lingers on, generating a limbo of common suffering in which a tenuous and moribund but all-embracing body politic springs into being". ${ }^{25}$ The struggle against the next pandemic is an enduring, never-ending epos insofar as we cannot simply block, isolate, annihilate, or sterilize the enemy, nature, but have to live within it and at the same time against it. Hence, in the "coming plague" scenario, the epidemiologist assumes the Promethean role of reconstituting human sociality, a task that can never be completed but is rather constituted by its very inconclusiveness, as an enduring negotiation between nature and culture that strives to safeguard human mastery. This, as well as the overall biopolitical aspect of the epidemiologist as a culture hero, finds its apotheosis in the blockbuster movie World War Z (2013), which ends with the protagonist speaking directly to the audience so as to point that, although a vaccine has been found, "this is not the end; this is the beginning of a long battle".

\section{The zombie pandemic}

Regressing from the diffused agency model of Contagion, World War Z reconstitutes the singular epidemiologist as culture hero in the figure of Gerry Lane (Brad Pitt). Although Gerry is not, strictly speaking, an epidemiologist but an ex-UN officer, after he manages to escape his zombie-stricken hometown, Philadelphia, he assumes the role of an epidemiological intelligence officer under the wing of the UN Deputy Secretary General. His role is to locate patient zero, the ultimate index patient of what Harvard virologist Dr. Andrew Fassbach (Elyes Gabel) suspects to be a virus that turns humans into zombies. The virus is transmitted through a bite, its incubation period being reduced to a few seconds - an extraordinary dramaturgical effect that seems to be borrowed from earlier films such as The Andromeda Strain. Though coined zombies, these infectious vectors have nothing in common with the rich objectifying ontology of "menacing passivity" developed in George Romero's "living dead" trilogy, where, as Steven Shaviro has demonstrated, zombies acquire a subversive, even redemptive character: "the living dead are not radically Other so much as they serve to awaken a passion for otherness and for vertiginous dis-identification that is already latent within our own selves" ${ }^{26}$ If Romero's living dead are primarily characterized by the lack of origin or referent, their being "unmoored from meaning", a phenomenon that "defies causal explanation", in World War Z the identification of zombies' origin is the sole purpose and pathos of the film. It is no longer "the rebellion of death against its capitalist appropriation" but this microbiological origin that defines zombies, while, at the same time, interpellating, in Louis Althusser's sense of the term, the epidemiological culture hero of the film. ${ }^{27}$ In this sense, World War Z zombies are no longer part or 
a variant of the "living dead" mythology, which Gilles Deleuze and Felix Guattari saw as the last modern myth; they no longer "literalize and embody an extremity of agitation, an ecstatic emptying of the self, a mimetic contagion". ${ }^{28}$ Rather, they are a race of rabid and rapid superspreaders, thus embodying par excellence the agency of reverse anthropogenesis discussed in Chapter $3 .{ }^{29}$

The idea of zombification being the result of a zoonotic disease, and of zombies being the ultimate, even one may claim ontic, superspreaders of an end-of-theworld infection first appeared in the film 28 Days Later (2002). There, animal rights activists break into a Cambridge lab and release a chimpanzee infected with an experimental virus called "Rage". The chimp bites its releaser, who is instantly infected and assumes an enraged rabid-looking aspect, infecting in turn her comrades, as well as a white-coat scientist who tries in vain to warn them about the "highly contagious" disease carried in the blood of the primate. The film is titled 28 Days Later, as the main plot unfolds after that time span, during which nearly the entire population of Britain has become infected with "Rage".

Partially, as a number of analysts have claimed, as a result of the woes of the Great Recession (2008 onward), zombie infection has quickly become a potent metaphor in popular culture, attracting scholarly interest from across the disciplines. ${ }^{30}$ In the last ten years, "zombie infection" and "zombie pandemic" have become popular video games and grassroots prep practices and groups such as the Zombie Squad have taken to the streets of the USA. ${ }^{31}$ The National Geographic has featured an article claiming that a zombie or "rage virus" could emerge out of a rabies bird flu hybrid. ${ }^{32}$ More importantly, however, the US CDC has opted to use the zombie metaphor to talk about disease outbreaks and how we should respond to them. In 2011, the Zombie Preparedness Campaign by the CDC Office of Public Health Preparedness and Response featured well-designed posters showing a zombie peering through a window: "Don't be a Zombie, be Prepared" (Fig. 4.1). These were accompanied by "Zombie survival kits", as well as a two-part graphic novel, Preparedness 101: Zombie Pandemic. ${ }^{33}$ Ali Khan identified the inspiration of the campaign as based on the popularity of the "zombie apocalypse" in popular culture. He further claimed that answering the question "how do I prepare for a zombie apocalypse?" would help to "share a few tips about preparing for real emergencies too!". ${ }^{44}$ The zombie campaign was a major success, with the CDC website allegedly crashing due to the number of people visiting it. ${ }^{35}$

Screened only two years after the CDC Zombie Preparedness Campaign, World War $Z$ shares its pro-science attitude. It hence differs radically from earlier zombie films, as well as from the popular zombie TV series The Walking Dead (Darabont, 2010) in its attitude toward the solution to infection and the role of the militaryscientific complex in it. In the last film of the "living dead" trilogy (Day of the Dead; Romero, 1985), the military-scientific complex is famously ridiculed as effectually being more dead than the zombies, with the final zombie invasion of the militarized underground safety zone being portrayed as a moment of deliverance rather than damnation. ${ }^{36}$ Similarly, in 28 Days Later, science seems to have evaporated while the British Army is but nine soldiers hiding in a manor house near the city of Manchester. The soldiers are interested only in hot water, 


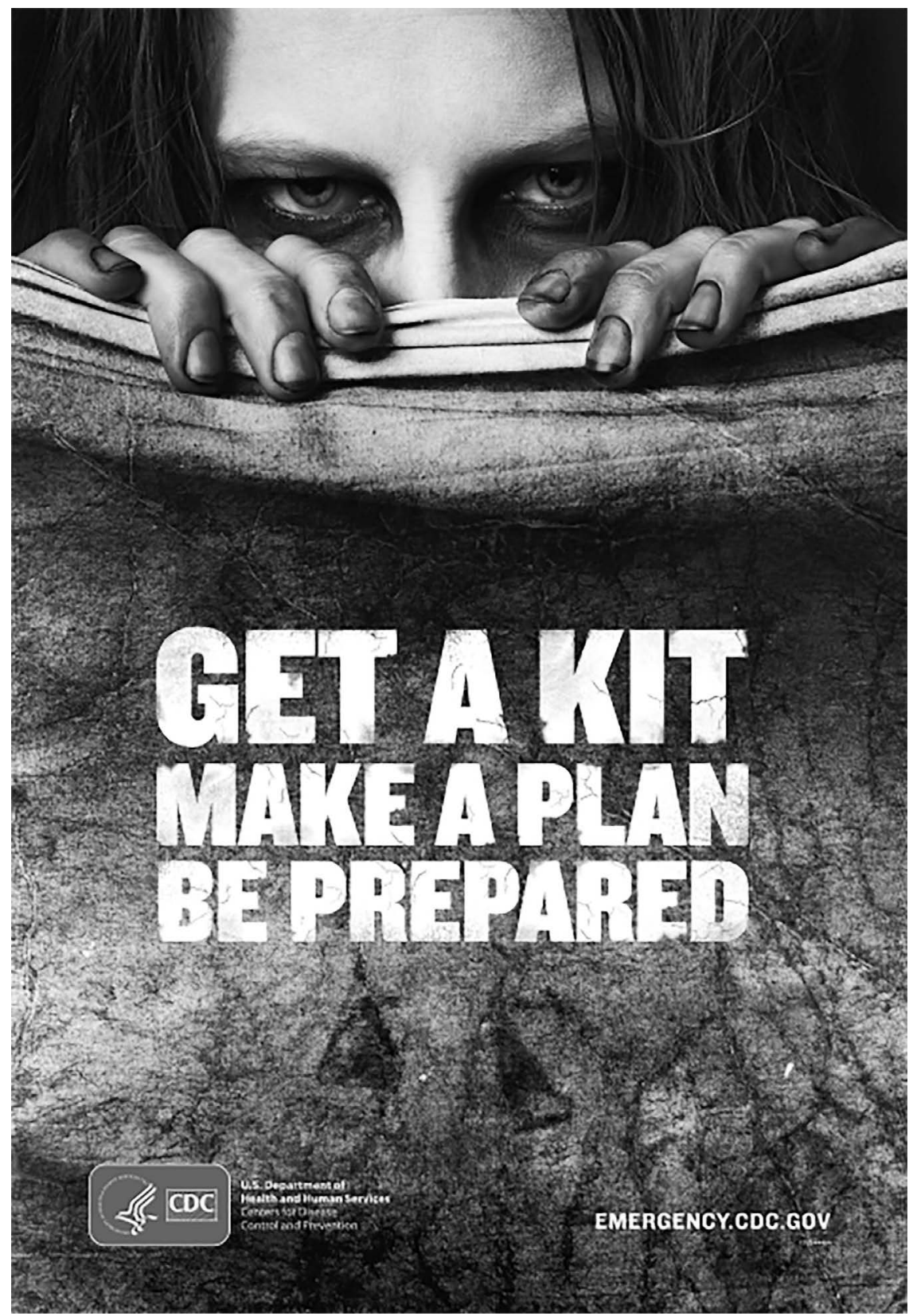

Figure 4.1 US CDC poster accompanying “Zombie Preparedness 101” campaign, 2011. Source: Courtesy of the US Centers for Disease Control and Prevention 
idle talk over candlelit dinner, and raping women who they manage to lure into their decadent hiding place with the help of a decoy radio-broadcast, promising an "answer to the infection". This scathing critique of the military-scientific complex is repeated in Francis Lawrence's blockbuster film I Am Legend (2007), which tells the story of a man-made zombifying virus outbreak in New York City. The film not only portrays scientists as responsible for the pandemic (the fictional "KV virus" being the result of bioengineering of measles into a cancer treatment) but also reveals the serum-seeking efforts of the last remaining scientist in "ground zero" Manhattan, virologist Dr. Robert Neville (Will Smith), as lacking an elementary understanding of natural selection. ${ }^{37}$ Entangled within his laboratory rituals, Dr. Neville fails to grasp that zombies, rather than KV-immune humans, are the new evolutionary stage of (post)humankind. Finally, in the TV series The Walking Dead, any hope of scientific help evaporates already during the first season (2010), when the Atlanta CDC HQ, whose staff have either killed themselves or fled for their lives, self-explodes. ${ }^{38}$

In contrast to these critical narratives, World War Z's aim is not to challenge but to affirm the vitality of biopolitical power under the wing of the militaryscientific complex. Supported by elite armed forces, Gerry Lane lands in South Korea, where, after the Harvard virologist is accidentally killed, he finds himself in charge of the whole epidemiological intelligence operation. Following the lead of an imprisoned CIA agent, he then takes off to Jerusalem, where we witness the failure of the "old way" of protecting society from infection: the wall. Having intercepted an Indian military signal months ahead of the global pandemic, the Mossad concludes that the only protection for Israeli citizens is to erect an enormous wall around Jerusalem. All comes to ruin, however, when joyous Jewish and Muslim refugees unite to chant through megaphones their praise to God for saving them behind the wall. Hearing the amplified cross-confessional hallelujahs, zombies swarm the fortifications; they self-organize into a huge undead pyramid and manage to enter and infect the Holy City. ${ }^{39}$

It is during his escape from the chain infection of Jerusalem that Gerry witnesses two exceptional events: zombies overlooking and running past a frail old man, and a sickly looking boy who crouches on the ground as the infected hordes run howling past him. Gerry's epiphany is thus reached on the road to Jerusalem's airport, where he intercepts a Belarus Air passenger plane and orders it to change its route to the closest remaining WHO lab, in Cardiff, Wales. Gerry has to blow up the aircraft with a grenade just above Cardiff, as a stowaway zombie has caused a chain infection in the economy and, alas, soon after also in the business class of the aircraft. Reaching the WHO lab, Gerry finds it infected with the virus, due to an accident that occurred in the course of the scientists experimenting on it. Gerry requests the remaining uninfected biologists to provide him with their most lethal but treatable pathogen, which, after the usual adventures, he injects himself with, hence becoming "invisible" to the zombies, which run past him. A "vaccine" has thus been found, which, by rendering people treatably ill, makes them imperceptible to zombies, who have been "programmed" by the virus to infect only healthy hosts. 
Given this resolution, one is left to wonder how it could be that nobody previously noticed that zombies spared hospitalized or otherwise ill patients. ${ }^{40}$ More importantly, however, what we have to consider here is the role of the epidemiologist as a culture hero who brings humanity back to life by bringing it illness. What is at stake here is clear: "civilized" versus "savage" infectious diseases - a pathogen with a history, a biography, and an established career track-record versus a novel, emergent pathogen - a mysterious, enraged, and primitive virus. One needs to pause here so as to consider emerging infectious diseases, the category preoccupying pandemic scenarios since 1989 , as the breach of an ontological contract: the idea, current since the eradication of smallpox (c. 1980), that developed countries had moved beyond the pale of plagues and into the realm of noninfectious chronic disease. In this sense, emerging infectious diseases are imagined to threaten not simply our health but also our illness, as a social evolutionary stage of sorts. They supposedly threaten to drag the West back to a previous step of the evolutionary ladder, where societies stand challenged not by obesity, cardiovascular disorders, diabetes and cancer, that is, by intrinsic problems of the human organism, but by germs as extrinsic threats that were largely believed to be problems of "developing nations" only. That is why the solution provided by our culture hero, Gerry Lane, is so ingenious. He is no zombie-slayer; he does not go out there like the Indian Army in a futile mission to massacre the undead, nor does he, like the Mossad, regress to medieval, sovereign solutions (the walled citadel), nor does he opt to abolish individual freedom by adopting the radical North Korean solution to the zombie epidemic: pulling all citizens' teeth out, thus depriving them from the means of infection. Instead, he fights the zombie plague by mass-introducing a cooked illness, in Lévi-Straussian terms: a domesticated pathogen, doctored in labs, tamed into a vaccine that camouflages humanity before the savage, raw zombie virus. By rendering a large part of surviving humanity artificially ill, the culture hero provides a mediating condition between life and death and delivers it from zombification.

\section{Man the man-hunter and the re-pastoralization/pasteurization of humanity}

The significance of World War $Z$ lies with its power to visually bring together two imaginaries, concerning emerging infectious diseases and zombies, in a biopolitical myth about total infection and ways of preventing it. The film follows the 28 Days Later paradigm in displacing the focus from zombies as a menace-in-itself (a theme that dominates classic zombie filmography) toward the zombie virus as a parasitic hyper-life that overrides the human organism and afflicts not one or multiple physiological functions or even the totality of the human body but human being as such. Zombies are furthermore not simply vectors of disease; they have become totally identified/merged with it. Not only do they portray a total change of behavior, such as is also evident in the case of rabies, but they also evince a transformation in the species-being of humans. On a first level, this transformation lies with the fact that the undead faculty of zombies loses the primary 
ontological status it holds in classic filmography and becomes a side effect of viral infection or rather a way that the virus has found so as to make its vectors persevere and transmit it to a maximum number of contacts. This understanding of the virus resonates with the witty statement of the Harvard virologist on board the military plane bound to South Korea: "Mother Nature is a serial killer" ${ }^{41}$ Hence, the zombie virus is invested with intentionality: it wants to reproduce, it strives to transmit itself. This follows a popular pseudo-Darwinian understanding of life in general, according to which adaptation and survival are a goal rather than just a fact of life. There is, however, a more complex level on which the aforementioned bio-ontological transformation operates. This needs to be examined carefully, as it has significant implications for the establishment of the epidemiologist as culture hero and for the biopolitical destiny he or she embodies.

What can easily be misunderstood as a trivial dramaturgical detail in the World War $Z$ scenario, when in fact it holds a key exegetical position, is the information that zombies can no longer be infected by another pathogen, a method that, we are told, the Cardiff WHO scientists tried without success. What we have here is a portrayal of pure life. Hollywood had already provided us with what Stephen Mulhall has described as a predatory form of "life as such", "Nature incarnate or sublimed", in Ridley Scott's Alien (1979). ${ }^{42}$ Yet what differentiates Alien's xenoform from the viral zombie, in spite of their common embodiment of "pure evil animality overlap[ing] with machinic blind insistence", is that while the former reproduces by impregnating humans with baby-aliens, who come to life by destroying their host, in the case of World War $Z$ the viral form of hyper-life as pure information rides on the back of organic matter in a communication paroxysm. ${ }^{43}$ Everyone becomes a superspreader without the virus actually killing anyone (the usual burn-up limit to the effectiveness of infection).

At the same time, the zombie virus is a form of life that needs no social context. It is elementary epidemiological knowledge that all human pathogens operate within strict social-ecological parameters. A bubonic or pneumonic plague outbreak does not automatically result from the coexistence of Yersinia pestis and humans in a given locus but instead requires specific social contexts and relations, such as the hunting of infected hosts (e.g., marmots) or housing structures that allow rats' "blocked fleas" to access humans. Similarly, cholera outbreaks require water- and food-sharing practices, typhus outbreaks crowded habitation conditions, whereas the HIV/AIDS epidemic is conditioned on unprotected sex practices, sharing needles, and/or infected blood transfusion. What renders the fictional zombie virus unlike any other pathogen is not only its exclusive, totalizing nature, which allows no coinfection, but also that its transmission and spread is free of any social context or relation. Its human vectors break down all social barriers and operate without any social context so as to reach new targets of infection. As "life as such", as a floating signifier, the zombie virus demolishes all mediation, instituting a reign of pure viral immanence.

It is crucial here to examine this paradigmatically a-social and a-ecological mode of transmission of the virus, for this is none other than man-hunting. As evident from the very first act of World War $Z$, the Philadelphia attack scene, 
zombies hunt down potential virus receptors and bite them, thus transmitting the virus and transforming their prey into new, predatory vectors. It is characteristic that the only time when zombies assume the classic Romerean aspect of slowness in the film is when there is a lack of human targets for infection. In this condition, zombies become idle and simply linger in one place, hovering in a state of quasihypnotic readiness, until the slightest human-produced sound brings them back to a paroxysmal, predatory state of existence, where their sole purpose becomes to bite the signal source.

Zombies hence reduce the entirety of humankind into a hunted-humanity. Here we need to follow Grégoire Chamayou, who in his book on "manhunts" provocatively argues for man-hunting's place next to Michel Foucault's pastoral technology of power. ${ }^{44}$ Based on a commentary from the foundational work of the Kabbalah, The Zohar, Chamayou sets the original sovereign, the Biblical founder of Babel, Nimrod, as the prototypical man-hunter: "on the one hand we have Nimrod, cruel tyrant and idolater, and on the other hand Abraham, peaceful and virtuous shepherd". ${ }^{45}$ The contrast between the two figures, claims Chamayou, "became a topos of Biblical commentary", as a contrast between Babylon and Israel, and thus forms a symmetric opposition between two models of political power. ${ }^{46}$ Nimrod's man-hunting power opposes Abraham's pastoral power as its "true antithesis": if the latter is transcendental and aimed at the total submission of humanity to divine will, the former is fundamentally immanent, its aim being none other than to capture humanity within a sovereign apparatus. This is why, Chamayou argues, "the reign of the hunter-king is not just the first power on Earth, but also the first properly speaking earthly power (pouvoir terrestre), whose authority does not derive from any transcendental source". ${ }^{47}$ It is this immanence offorce that Chamayou sees as the fundamental characteristic of cynegetic power. We may thus say that in the next pandemic scenario of World War Z, all humanity, which had hitherto chosen the pastoral rule of Abraham, comes under the cynegetic power of Nimrod - none other than the man-hunting zombie virus, whose emergent immanence is such that it has not even a name. Hunting humans by means of humans, the viral hunter-king may or may not have a crown (depending on whether it is a coronavirus), yet what it certainly has is "earthly power". Free of any external referent or social-ecological context, the zombie virus is the embodiment of the negation of transcendence. Even the direct progeny of Abraham, the Jews and Muslims of Jerusalem, are not immune to its immanent force that transforms its captured prey into predator, hence universalizing the cynegetic principle by returning humanity to its imagined as original, natural, and immanent state: "man the hunter" or rather "man the man-hunter".

In order to fully grasp the import of this viral-cynegetic paradigm and its biopolitical implications, it is pertinent to return to World War $Z$ so as to examine more closely the North Korean mode of containing the pandemic. This is essentially presented as based on a preventative anti-cynegetic technique taken to extremes. The CIA agent whom Gerry Lane interviews in the military base of Camp Humphreys calls the North Korean method (pulling all teeth out, so that nobody can bite) the most successful experiment in social engineering in human history. 


\section{The epidemiologist as culture hero}

Rather than simply being a cheap ironic commentary on state socialism, this is a statement not so much about the phagic aspect of the infection (zombies in this film bite but do not eat humans) as about "man the hunter". The North Korean regime's method may in fact have been successful in containing the pandemic from spreading south of the Thirty-Eight Parallel and north of the Yalu River but at the cost of dehumanizing all potential vectors. The Politburo's decision to pluck out the teeth of its subjects prevents the latter from becoming vectors only through the denial of the cynegetic potentiality of humanity as such. If human civilization is imagined to be a process of emergence, through which "man the hunter" goes through a Neolithic Revolution that renders humankind pastoral, this is not supposed to be an all-out evolutionary achievement or the result of some political theological transcendence. It is rather an enduring dialectical process that continuously posits cynegetic and pastoral techniques and principles one against the other. The essentially Stalinist, anti-dialectical solution adopted by the Workers' Party of Korea is thus a betrayal of human civilization as such, as a constant negotiation between nature and culture. On the contrary, our culture hero seeks a solution at the opposite side of the anthropological spectrum: camouflage (Table 4.1).

What happens when Gerry Lane injects himself (and then others) with a treatable, domesticated pathogen is a process of rendering himself indistinct vis-à-vis the zombie virus. In line with Neil Leach's work on camouflage, we must seek to understand how this technique works on both a strategic and an ontological level. ${ }^{48}$ Leach has argued, echoing earlier anthropological studies of the mask, that "the role of camouflage is not to disguise, but to offer a medium through which to relate to the other" ${ }^{49}$ This is all the more relevant in relation to the epidemiologist as culture hero, a role that is fundamentally one of an intermediary. Contra Leach, however, the efficacy of this medium is not based on its power of representation. ${ }^{50}$ This is a nonmimetic camouflage, or camouflage devoid of aesthetic dimensions, visual or otherwise: nothing changes in how the artificially infected culture hero looks. Gerry Lane is in all appearance his old healthy self, enjoying a rare moment of normality by sipping a can of Pepsi; he does not stagger, nor does he look pale, frail, or sick. The infectious zombie hordes overlook him and run past him in a frenzy, not because of his appearance but because of his altered being. This is where World War $Z$ reaches its highest moment of anthropological metaphysics, which must be taken seriously so as to understand its biopolitical implications and its wider role in the pandemic imaginary. ${ }^{51}$

Like any of its usual natural manifestations (e.g., the Giant Katydid), here too camouflage is operative on the basis of an interaction between self and other, or

Table 4.1 Zombie Containment Pathways in World War Z (USA and UK, 2013)

\begin{tabular}{lllll}
\hline & India & Israel & North Korea & UN \\
\hline Method & War & Wall & Pulling teeth & Vaccine \\
System & Secrecy & Political theology & Totalitarianism & Camouflage \\
Outcome & Defeat & Defeat & Dehumanization & Success \\
\hline
\end{tabular}


on what, following Roger Caillois, we may describe as a relational concealment based on the manipulation of distinction. ${ }^{52}$ Yet the domesticated illness jab does not operate, as one might have expected, on a biological or physiological level predicated on its biochemical properties. It does not change the appearance of the self vis-à-vis its prospective predator, but rather shifts the very ontological value of predator-prey interaction. ${ }^{53}$ For if, as I have already mentioned, the cynegetic relation upon which zombie infection operates requires no social context, what it does need is an ontological equivalence: as pure sovereign, the man-hunting virus seeks to infect subjects so as to render them into man-hunters in turn. What the injection of another pathogen achieves qua a process of what, paraphrasing David Napier, we can call de-selective dissociation, is to transform human beings from subjects into quasi-objects, in Michel Serres' sense of the term. ${ }^{54}$ The preventative infection of humans by the culture hero is distinct from vaccination in general, for the reason that this operation is not predicated upon the immunological familiarization of the self with a nonself but rather upon rendering the self totally imperceptible by the nonself through erasing its own selfhood. ${ }^{55}$ No longer a self, the human being becomes indifferent to the nonself virus. The injection hence deprives the pandemic apparatus of capture from its object proper: humans as subjects. As quasi-objects of another pathogen, humans no longer fulfill their role as ontological targets of the pure-life zombie virus.

In this mythocosmological variant of the end of the world, the epidemiologist as culture hero is hence able to save humanity from extinction by folding life into death, and subjecthood into objecthood, a task performed through the double process of re-pastoralization and re-pasteurization. ${ }^{56}$ On the one hand, the epidemiologist re-pastoralizes humanity as a whole: he salvages it from the realm of cynegetic immanence and re-socializes it. ${ }^{57} \mathrm{He}$ acts like the classical culture hero mediator who negotiates a fecund separation/mediation between nature and culture. This re-pastoralization is not, however, achieved through a flocking-in of social actors, such as in the futile effort of the Mossad to re-enclose humanity within the political theological structure of the wall. Nor is it achieved through rendering social actors docile, as in the dehumanizing social engineering experiment of the North Korean regime. Instead, the re-pastoralization of humanity is achieved through the re-pasteurization of individuals: through their transformation into quasi-objects by a process of temporary infection.

There is indeed a pervasive Pasteurian metonymy in operation here, following which, humans, as yet-uninfected subjects, stand for Louis Pasteur's famous growth medium. Both sterile and containing nutritive value, the medium stands to be infected once exposed to non-sterilized air, in other words, to the environment. The infectivity of humans thus evinces their being alive and, at the same time, their being open to the world around them. ${ }^{58}$ By contrast, being no longer human, zombies cannot be infected by another pathogen and are hermetically closed into their own immanence. Hence, the transformation of humans into quasi-objects is portrayed as a condition of preserving their potentiality as social beings vis-à-vis a pervasive existential risk. 


\section{The epidemiologist as culture hero}

The anthropological import of this cinematographic production of the next pandemic thus becomes clear: humanity can retain its sociality, and the world can come out of its state of pathogenic imbalance (to invoke Laurie Garrett's influential, structural-functionalist metaphor) only if humans forsake their liberal-autonomous self for a more healthy and sustainable form of limited agency. In other words, humans can subvive vis-à-vis the soon-to-erupt, imagined as inevitable pandemic, only if they preemptively self-limit themselves. ${ }^{59}$ It is as an operator of this process of internalizing the neoliberal governmental principle of self-limitation as an existential necessity for humanity that the twenty-first-century epidemiologist finds his or her place in the mythic pantheon of culture heroes and his or her operation in the pandemic imaginary.

\section{Notes}

1 Barbara G. Myerhoff and William R. Larson, "The Doctor as Culture Hero: The Routinization of Charisma," Human Organization 24 (1965): 188-191.

2 Myerhoff and Larson, "The Doctor as Culture Hero: The Routinization of Charisma," 188.

3 Orrin Klapp, "Creation of Popular Heroes," American Journal of Sociology 56 (1948): 135-141.

4 Myerhoff and Larson, "The Doctor as Culture Hero: The Routinization of Charisma," 189.

5 Michael P. Caroll, "Lévi-Strauss, Freud, and the Trickster: A New Perspective Upon an Old Problem," American Ethnologist 8(2) (1981):301.

6 Richard Preston, The Hot Zone: A Terrifying True Story (New York: Anchor 1994). On how Outbreak was inspired by Preston's work and its Hollywood race for realizing this in the silver screen, see: Dhalia Schweitzer, Going Viral: Zombies, Viruses, and the End of the World (New Brunswick: Rutgers University Press, 2018).

7 Kirsten Ostherr, Cinematic Prophylaxis: Globalization and Contagion in the Discourse of World Health (Durham, NC: Duke University Press, 2005). See also: Heather Schell, "Outburst! A Chilling Story about Emerging-Virus Narratives and Pandemic Social Change," Configurations 5(1) (Winter 1997): 93-133. On epidemic films as horror films, see: Hugo Clémot, "Une lecture des films d'horreur épidémique," Tracés. Revue de Sciences humaines 11 (2011): 167-184.

8 Ostherr, Cinematic Prophylaxis, 183.

9 Ostherr, Cinematic Prophylaxis, 181.

10 Adato Kiku, Picture Perfect: Life in the Age of the Photo Op (Princeton: Princeton University Press, 2008).

11 On the importance of the notion of "real time" in epidemiology, see: Carlo Caduff, "Sick Weather Ahead: On Data-Mining, Crowd-Sourcing and White Noise," The Cambridge Journal of Anthropology 32(1) (2014): 32-46.

12 Kiku, Picture Perfect: Life in the Age of the Photo Op.

13 Anon., "Contagion Production Notes" Warner Bros: Pictures, September 9, 2011, accessed January 11, 2014 www.visualhollywood.com/movies_2011/contagion/notes.pdf

14 Winslet in Anon., "Contagion Production Notes."

15 Cotillard in Anon., "Contagion Production Notes."

16 Cotillard in Anon., "Contagion Production Notes." For further analysis of the particular film, see: Marouf A. Hasian, Jr., Representing Ebola: Culture, Law, and Public Discourse about the 2013-2015 West African Ebola Outbreak (Lantham, MD: Rowan \& Littlefield, 2016), Chapter 6.

17 Antonin Artaud, The Theater and Its Double (New York: Grove Press, 1958), 24.

18 Artaud, The Theater and Its Double, 24-25.

19 Jacobs in Anon., "Contagion Production Notes." 
20 In Molly McCollom and DragonKhan,"Centers for Disease Control and Prevention," Public Health Matters Blog,2011, accessed February 10, 2014 http://blogs.cdc.gov/ publichealthmatters/2011/10/dragonkhan/ For a broader study of fiction and the CDC, see: Dhalia Schweitzer, "Pushing Contagion: How Government Agencies Shape Portrayals of Disease," The Journal of Popular Culture 50(3) (2017): 445-465.

21 Ostherr (2005: 178) has noted that NBC Nightly News covered the June 1995 Ebola outbreak in Zaire with accompanying clips from Outbreak, with no verbal acknowledgement of the fictional character of the footage. On Outbreak's impact on representations of Ebola, see: Marouf A. Hasian, Representing Ebola.

22 For an analysis of the end of the world and The Planet of the Apes, see: Mark Poindexter, "Apocalyptic Dread and The Planet of the Apes," In Apocalyptic Chic: Visions of the Apocalypse and Post-Apocalypse in Literature and Visual Arts, eds. Barbara Brodman and James E. Doan, pp. 165-182 (Madison, NJ: Fairleigh Dickinson University Press, 2018).

23 Molly McCollom, "Dragon*Khan," Centers for Disease Control and Prevention Public Health Matters Blog, October 12, 2011, accessed November 23, 2013 http://blogs. cdc.gov/publichealthmatters/2011/10/dragonkhan/

24 McCollom, "Dragon*Khan."

25 Elana Gomel, "The Plague of Utopias: Pestilence and the Apocalyptic Body," Twentieth Century Literature, 46(4) Literature and Apocalypse (2000), 406.

26 Steven Shaviro, The Cinematic Body (Minneapolis and London: University of Minnesota Press, 1993), 94, 98.

27 Shaviro, The Cinematic Body, p. 83.

28 Gilles Deleuze and Felix Guattari, Capitalism and Schizophrenia II: A Thousand Plateaux (London: Continuum, 2004); Shaviro, The Cinematic Body, 103.

29 For the iconographic and narrative development of the zombie figure, see also: Deborah Christie and Sarah Juliet Lauro, Better Off Dead: The Evolution of the Zombie as Post-Human (New York: Fordham University Press, 2011). For a critique of the new zombie genre, see: Evan Calder Williams, Combined and Uneven Apocalypse (Washington, DC: Zero Books, 2011); David Cunningham and Alexandra Warwick, "The Ambassadors of Nil: Notes on the Zombie Apocalypse," In Apocalyptic Discouse in Contemporary Culture: Post-Millenial Perspectives of the End of the World, eds. Monica Germana and Aris Mousoutzanis (London and New York: Routledge, 2014). Several studies have focused on the recently "accelerated" zombies and the relation of this phenomenon to political economic and biopolitical transformation: Yari Lanci, "Zombie 2.0: Subjectivation in Times of Apocalypse," Journal for Cultural and Religious Theory 13(2) (Spring 2014): 25-37; Stephanie Boluk and Wylie Lenz, "Infection, Media, and Capitalism: From Early Modern Plagues to Postmodern Zombies," Journal for Early Modern Cultural Studies 10(2) (Fall/Winter 2010): 126-147. On the connection between the rapidness of the new zombie's movement and the zero time of the zombie virus incubation period, see: Schweitzer, Going Viral: Zombies, Viruses, and the End of the World.

30 Daniel W. Drezner, "Metaphor of the Living Dead: Or, the Effect of the Zombie Apocalypse on Public Policy Discourse," Social Research: An International Quarterly 81(4) (Winter 2014): 825-849. For a broad spectrum of analytical approaches to the zombie phenomenon, see: Sarah Juliet Lauro (ed.), Zombie Theory: A Reader (Minneapolis: University of Minnesota Press, 2017); Stephanie Boluk and Wylie Lenz (eds.), Generation Zombie: Essays on the Living Dead in Modern Culture (Jefferson: McFarland \& Co, 2011).

31 Chad Huddleston, "Are You Prepared for Zombies?," American Anthropological Association Blog, April 11, 2012, accessed January 26, 2016 htpp://blog.aaanet. org/2012/04/11/are-you-prepared-for-zombies

32 Ker Than, “'Zombie Virus' Possible via Rabies-Flu Hybrid,"National Geographic News, October 27, 2010, accessed February 21, 2014 http://news.nationalgeographic. co.uk/news/2010/10/1001027-rabies-influenza-zombie-virus-science/ 
33 Maggie Silver, Preparedness 101: Zombie Pandemic (Atlanta: Centers for Disease Control, U.S. Department of Health and Human Services, 2011). For an internal evaluation by the CDC, see: Monique Halabi, et al., "Zombies-A Pop Culture Resource for Public Health Awareness," Emerging Infectious Diseases 19(5) (2013): 809-813. For analyses of the campaign, see: Julia Daisy Fraustino and Liang Ma, "CDC'S Use of Social Media and Humor in a Risk Campaign - 'Preparedness 101: Zombie Apocalypse'," Journal of Applied Communication Research 43(2) (2015): 222-242; Marjorie Kruvand and Maggie Silver, "Zombies Gone Viral: How a Fictional Invasion Helped CDC Promote Emergency Preparedness," Case Studies in Strategic Communication 2 (2013): 34-60. For critical responses from a public health perspective, see: Matthieu J. Guitton and Cecile Cristofari, "Does Surviving the Zombie Apocalypse Represent a Good Model of Human Behaviour in Response to Pandemics?," Journal of Public Health Management Practice 20(4) (2014): 375-377; Joanna Verran, et al., "Monsters, Microbiology and Mathematics: The Epidemiology of a Zombie Apocalypse," Journal of Biological Education 48(2) (2014): 98-104; London Draper Lowe and Faye I. Hummel, "Disaster Readiness for Nurses in the Workplace: Preparing for the Zombie Apocalypse," Workplace Health and Safety 62(5) (2014): 207-213; Mark Davis, "“Is It Going to Be Real?' Narrative and Media on a Pandemic," Forum: Qualitative Social Research 18(1) (January 2017) www.qualitative-research.net/index.php/fqs/article/ view/2768/4067

34 Ali S. Khan, "Preparedness 101: Zombie Apocalypse," Centers for Disease Control and Prevention, Public Health Matters Blog, May 16, 2011, accessed February 4, 2014 https://blogs.cdc.gov/publichealthmatters/2011/05/preparedness-101-zombieapocalypse/ (emphasis in original).

35 According to Neil Gerlach and Sheryl N. Hamilton (2014), "The original post received three million views and garnered more than five hundred comments. Posted on Monday, the CDC server crashed on Wednesday because of all the traffic, and by Thursday both 'CDC' and 'Zombie Apocalypse' were top ten Twitter trends".

36 Shaviro, The Cinematic Body, 93.

37 For more discussion on the particular film, see Chapter 6. For an analysis of Richard Matheson's homonymous book, see: Mathias Clasen, "Vampire Apocalypse: A Biocultural Critique of Richard Matheson's I Am Legend,"Philosophy and Literature 34(2) (October 2010): 313-328.

38 Frank Darabont, The Walking Dead, Season 1, Episode 1, "Days Gone Bye," October $31,2010$.

39 Scott Forth, "A Biophysicist Fact-Checks World War Z's Swarming, Sniffing, Tireless Zombies," June 25, 2013, accessed January 10, 2014 http://www.vulture.com/2013/06/ biophysicist-assesses-world-war-z.html. On the material and metaphorical uses of walls as sovereign devices in a globalized world of connectedness, see: Wendy Brown, Walled States, Waning Sovereignty (Cambridge, MA: Zone Books, 2010).

40 For a short cartoon with over 10 million views, making this point tongue in cheek, see: How It Should Have Ended, "How World War Z Should Have Ended," October 29, 2013 www.youtube.com/watch?v=Ow2Uh51IMh4

41 I would like to thank Robert Peckham for bringing this to my attention.

42 Stephen Mulhall, On Film (London and New York: Routledge 2001), 19.

43 Slavoj Zizek, How to Read Lacan (London: Granta Publications 2006), 63.

44 Grégoire Chamayou, Les chasses à l' homme: Histoire et philosophie du pouvoir cynegetique (Paris: La Fabrique, 2010). For an anthropological examination of Foucault's notion of pastoral power in a medical setting, see: Angela Garcia, The Pastoral Clinic: Addiction and Dispossession along the Rio Grande (Berkeley, CA: University California Press, 2010).

45 Chamayou, Les chasses à l' homme, 23. All translations from Chamayou are mine, as I find the Princeton University Press 2012 translation problematic in places.

46 Chamayou, Les chasses à l' homme, 23, 24, my translation. 
47 Chamayou, Les chasses à l'homme, 25, my translation.

48 Neal Leach, Camouflage (Cambridge, MA: The MIT Press, 2006).

49 For example, David Napier, Masks, Transformation, and Paradox (Berkeley, CA: California University Press, 1987); Leach, Camouflage, 240. For a broader discussion of masking and epidemics, see: Christos Lynteris, "Plague Masks: The Visual Emergence of Anti-Epidemic Personal Protection Equipment," Medical Anthropology 37(6) (2018): 442-457. I would like here to thank David Napier for a long-standing exchange on the relation between masking, camouflage, and immunology, which is more fully expressed in the above-mentioned article.

50 Leach, Camouflage, 243.

51 For a different reading of the biopolitical implications of World War Z, see: Karolina Słotwińska, "The Rising Multitude: Zombie Invasion and the Problem of Biopolitics in Max Brooks's World War Z," Polish Journal for American Studies 9 (2015): 151-164.

52 Leach, Camouflage, 243-244; Roger Caillois, "Mimicry and Legendary Psychasthenia," 1935 http://generation-online.org/p/fpcaillois.htm

53 This operation resembles mimetic hunting in Siberia (Willerslev 2007), yet its lack of social context limits the scope of this comparison.

54 A. David Napier, The Age of Immunology: Conceiving a Future in an Alienating World (Chicago: The University of Chicago Press, 2002); Michel Serres, The Parasite, translated by Lawrence R. Schehr (Minneapolis: Minnesota University Press, 2007).

55 A. David Napier, "Penser 'vaccinologiquement': une sélection qui n'est pas vraiment naturelle," In L'Aventure de la vaccination, ed. Anne-Marie Moulin (Paris: Fayard 1996). See also: A. David Napier, "Epidemics and Xenophobia, or, Why Xenophilia Matters," Social Research: An International Quarterly 84(1) (Spring 2017): 59-81.

56 Leach, Camouflage, 246.

57 Bruno Latour, The Pasteurization of France, translated by Alan Sheridan (Cambridge, MA: Harvard University Press, 1993). For an examination of the Ebolavirus as precariously and productively positioned between the pastoral and the predatory, see: Frédéric Keck, "Ebola, entre science et fiction," Anthropologie \& Santé 11 (2015) doi:10.4000/ anthropologiesante. 1870

58 Harry Collins and Trevor Pinch, The Golem: What You Should Know about Science (Cambridge: Cambridge University Press, 2012), 80.

59 For a discussion of zombies and neoliberalism, see: Lanci, "Zombie 2.0: Subjectivation in Times of Apocalypse." 


\section{The post-pandemic condition}

In his homonymous study, James Berger has argued that the temporal formula "after the end" is oxymoronic: "before the beginning and after the end, there can only be nothing". ${ }^{1}$ And yet, as he notes, the scheme persists, most famously today in the broad and much-used notion of the "post-apocalyptic", the narrative of which allows us "to be at both places at once, imagining the post-apocalyptic world and then paradoxically 'remembering' the world as it was, as it is". Although the next pandemic is indeed supposed "in its destructive moment [to] clarify and illuminate the true nature of what has been brought to an end" - that is, humanity as a project for mastery - the time following the next pandemic does not mark a post-apocalyptic "after" as the former does not entail an apocalyptic temporality (discussed in Chapter 1 as katechon [DELAYS] anomy $\rightarrow$ eschaton) or the forms of agency that the latter affords. ${ }^{3}$

If this is still an "after the end", it is so only insofar as the "end" and the "after" are temporally collapsed into one another, so that what lies "after the end" is also the "end" of any "after". In other words, the time after the next pandemic is a time where there can be no after, no consequence, no future. And this is because in order for such a temporal register to exist what is required in the first place is a point of subjectivation: that of a subject capable of having an impact on the world, and in turn of becoming subject by means of this impact, exactly what the next pandemic is supposed to render categorically extinct.

So as to understand the way in which the post-pandemic condition operates in the pandemic imaginary, it is thus important to examine how it differs from "after the end" scenarios. In fact, thinking about "after the end" may not be as hard as one may originally assumed, on account of the oxymoron in place. We can, for example, easily think of a diverse range of historical "after the end" situations, including the Romans after the fall of Rome or Amerindians after the Conquest. ${ }^{4}$ If Berger is right in that understanding apocalyptic tropes of "after the end" entails a study of "what disappears and what remains, and of how the remainder has been transformed", in all these cases of what we may call historical ends of the world, the subjects of the post-end condition are not simply survivors of a catastrophe but agents (albeit compromised) of a new era. ${ }^{5}$ They have not simply lost the world as a world the relation to which (in different ways each) they mastered; they have also come to inhabit a world where mastery is shaped and exercised by others: 
schematically speaking, "barbarians" in the case of Rome and Europeans in the case of the Conquest.

By contrast, in the case of the next pandemic, humanity's relation with the world is supposedly to be marked by a radical erasure of mastery as a human capacity. Here lies the key difference between the post-apocalyptic and the postpandemic condition: the latter is a condition where the ex-agents of mastery come to inhabit a masterless world - not as a world lost to oneself (Roman, Tupi, etc.) in the sense that one's enemies, or more broadly "others", have come to assume the project of mastery, but a world lost in and of itself, insofar as relating to it is no longer mastered or indeed masterable by anyone. In short, the defining characteristic of the post-pandemic condition is not that we come to inhabit a world mastered by others (other humans, nonhuman animals, or, as SF scenarios may have it, extraterrestrials) but a world the relation to which is irreversibly and irreducibly both masterless and unmasterable. In contrast to historical variants of "after the end", where one is called to reclaim agency by embracing, adapting to, subverting, joining, or resisting the new subjects and forms of mastery, this is a position that allows no accommodation.

Two questions immediately arise from this point. Does a remainder of humanity survive the next pandemic in a similar way to which, in post-apocalyptic scenarios, "what survives is some version of humanity in the midst of the inhuman"?6 And does the pandemic imaginary allow for a post-pandemic condition that, to follow Casey Riffel's insightful analysis of Philip Dick's novel Do Androids Dream of Electric Sheep (1968), "makes possible new forms of species relations [as] new ethical relations [that] are directly tied to the rupturing of history"?

Following studies that demonstrate the irreducible entanglement between biological and metaphysical configurations of "life" in Western thought, but also philosophers like Quentin Meillassoux and Ray Brassier who have challenged existential precariousness as an ontological sine qua non, Joshua Schuster has recently attempted to reconcile approaches focused on speciation (or more broadly speaking, difference) and extinction (or more broadly speaking, collapse). Schuster begins by the premise that

Even if the initial cause of an extinction event is something biologically external - a comet or a severe change in climate - what ensues is a breakdown at the species level of the survival and reproductive capacities that maintain organisms and allow future speciation. ${ }^{8}$

And yet, he stresses, in its original, Darwinian sense, extinction is both destructive and generative, as "the appearance of new forms and the disappearance of old forms, both natural and artificial, are bound together". 9

Following Schuster in his Darwinian understanding of extinction, not simply as the end of life but as a factor of speciation and thus of life itself ("a view of life both enabled and effaced by extinction"), we are led to a conceptual fulcrum between our questions regarding, on the one hand, whether anything human remains after the next pandemic, and, on the other hand, whether new forms of 
species relations and new forms of species-being are made possible by the latter. ${ }^{10}$ This conceptual pivot is in fact best formulated in terms of a third question: What may the generative impact of human extinction - conceived not as a physical elimination of our species but as humankind's ontological demise - entail?

So as to answer this question, it is crucial to return to "mastery", which in this study has been employed against the grain of a long Hegelian, master/slave tradition of the notion. To sum up, the notion of mastery is here conceived not as synonymous with control, subordination, exploitation, command, domination, ownership, appropriation, or management nor, at the same time, as something exercised on other people, classes, animals, and so forth. Rather, it is treated as something exercised on humanity's relation with the world and pertaining primarily to a practice of rendering intelligible and actionable a range of relations between self and other.

Hence, if the post-pandemic condition is configured as irreducibly masterless and unmasterable, this lack of mastery concerns not the inability of humans to dominate, control, own, or manage other humans or nonhumans but their inability to dialogically render humanity's relations with the world intelligible and actionable. This then helps us reformulate our question in terms of Julietta Singh's recent, pertinent call for "unthinking mastery": If indeed, "the very notion of the human relies on and is totally unthinkable without mastery", does the pandemic imaginary allow for "a radically different understanding of what it could mean to be human or perhaps a thinking of the human that would not be human at all"? ${ }^{11}$

I would like to begin tackling this question by examining some key tropes of the post-pandemic condition, what we may call the post-extinction topology of the pandemic imaginary.

\section{Rewilding}

A key trope of the post-pandemic condition in the pandemic imaginary is the reconquest of the Earth by nature. Rather than it being construed as the final act in some drama involving the "revenge of nature", this is rather envisioned as the default and indeed immanent effect of the collapse of human agency in the world. The resulting image is the structural reverse of the image of the last hours of humanity. As has been already discussed, representations of the latter generally purport to reveal the bare bones of the human condition by replicating well-rehearsed tropes of societal collapse: supermarket looting, maddened scuffles for a packet of biscuits, and cars endlessly trapped on suspension bridges (preferably in Manhattan) in a hopeless and lethal effort to breach quarantine and escape (with as many commodities as can fit in the trunk) to the countryside. ${ }^{12}$ In the opening episode of the otherwise unremarkable Belgian pandemic TV series Cordon (2015), we find a blatantly misogynist image that condenses this trope: "ordinary housewives smashing windows, looting. The fever drives people crazy" ${ }^{13}$ By contrast, once the pandemic is over, such scenes of chaotic "anarchy" give way to a landscape of pathetic anomy: "The rat race was over, the freeways were clear all the way to Sacramento, and the poor dwindling ravaged planet 
was suddenly big and mysterious again". ${ }^{14}$ When the protagonist of T. C. Boyle's short story "After the Plague" eventually drives down from his mountain post, where he has survived the plague, to urban civilization, what he finds is an accelerated process of "rewilding": the local town

looked now as if it had been deserted for decades. Weeds had begun to sprout up through invisible cracks in the pavement, dust had settled over the idle gas pumps and the windows of the main building were etched with grime. ${ }^{15}$

Though only months had passed since the outbreak, the world "already seemed primaeval":

Everywhere the untended gardens ran wild, the lawns became fields, the orchards forests, and I took to walking round the neighbourhood with a baseball bat to ward off the packs of feral dogs for which Alpo would never again materialize in a neat bowl in the corner of a dry and warm kitchen. ${ }^{16}$

This image of nature hurrying up to reclaim the world, as if it had been held back by humanity for millennia and now managed to surge through, like gas under pressure, is a pervasive theme of post-pandemic narratives. The process of frenetic reclaiming of the urban terrain by nature needs, however, to be more precisely identified as a process through which the urban jungle "reverts" into a real one: "And the animals - the animals were everywhere, marmots wading across the lot as if they owned it, a pair of coyotes asleep in the shade of an abandoned pickup, ravens cawing and squirrels chittering". ${ }^{17}$ The image is familiar to audiences of movies like I Am Legend, where, in the iconic opening scene, Will Smith wonders through a savannah-like Manhattan rife with thriving wildlife. In a feature of the NY Magazine on the movie, we read that creating the particular "illusion of a verdant, depopulated Manhattan took \$40 million of the film's \$150 million budget". ${ }^{18}$ The film's director, Francis Lawrence, defended this decision in a manner that underlines the "accelerated nature" fantasy noted above: "Most apocalyptic movies are very dark, with burnt-out cities [...] The truth is that if people left, nature would start reclaiming the city pretty quickly". ${ }^{19}$

There are two contrastive images that may help us understand the mythocosmological operation of pandemic-borne urban rewilding. First, and most famously, the image of a ruined post-nuclear world, as this was developed and presented in a great number of novels and films in the course of the Cold War. Whether in fictional or docudrama variants of the theme, the world after the nuclear end is uniformly depicted as a global ruin. In a far-reaching metonymic act, in the nuclear imaginary human survival is often played out in deserts. The Book of Eli (2010) is a recent example of this, but similar images also pervade less action-oriented post-nuclear disaster narratives like A Boy and His Dog (1975). Interlinked with deserts as the loci of actual nuclear testing is the desert's eschatological potential as established in Judeo-Christian theology. ${ }^{20}$ Following Matilde Nardelli, "At the height of the Cold War, artists, writers and filmmakers 
in America turned to the desert as a space in which notions of 'the end' could be articulated". ${ }^{21}$ Adopting Malcolm Bull's distinction between ends that indicate finality and ends that indicate terminality, Nardelli has identified Cold War nuclear ends of the world with the latter temporality (as non-transcendental events), arguing that the desert "stood as a space already profoundly marked by the end - a place where the end might have already happened and, even, where it may continue to happen". ${ }^{22}$ Similarly, when post-nuclear drama is played out in urban settings, it employs the image of deserted cities. As Max Page notes, in the course of the Cold War the mytheme of the "empty city" (for which the 1960s TV series The Twilight Zone provides intriguing variants) was paradigmatically staged in New York City, whose "fall" was meant to stand for the fall of humanity. ${ }^{23}$ More than being simply a case of a "melancholic contemplation of decay, the dysphoric nostalgia of revelling in what can never be the same again", we need to read the nuclear imaginary as rife with ideas of human culture as a ruin. ${ }^{24}$ As Yael Navaro has stressed, developing an idea first formulated by Walter Benjamin in his Passagen-Werk, ruination is productive of affective spaces; a point also stressed in Jo Masco's analysis of "Nuclear America". ${ }^{25}$ In post-nuclear narratives, remnants of humanity rummage through such spaces in search for both material and affective resources - mainly memories of what used to be "to be human" ${ }^{26}$ Indeed, this is a trope related to classical approaches of catastrophe, in the Greek sense of the word, as a dramatic, indeed tragic "dénouement". In the words of Jean-Luc Nancy, "Catastrophe, that is turning back, overturning, and ruin according to the Greek sense of the word, seems to consist of this civilization turning back and falling over itself". ${ }^{27}$

More specifically, as recently discussed by Rachel Bruzzone, catastrophe in classical thinking took the form not simply of this or that disaster (war, famine, plague, etc.) but of "a nexus of calamities" where all disasters were "presented as acting in tandem" in a way that "involv[ed] simultaneous political, climatological, seismological, and pandemic crises". ${ }^{28}$ If in the contemporary world, the nuclear apocalypse stands precisely for this total catastrophe (panolethria, as Thucydides would say: Histories 7.87.6), it is of consequence that its outcome consists in a global projection of the classical vision of the "emptied city". As Bruzzone stresses, the theme of the emptied or deserted city forms a persistent image in Greek catastrophic thinking. From Pausanias' and Thucydides' use of the image of emptied or deserted households to fears expressed in Sophocles' play that the

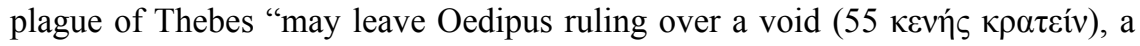
city bereft of men (57 $\varepsilon \rho \eta \mu ం \varsigma \alpha v \delta \rho \omega ́ v)$ ", depopulated cities played a key role in classical civic imaginaries, especially as topologies of mourning. ${ }^{29}$ Fifteen hundred years later, early modern depictions of plague-struck cities in Renaissance Italy reproduced this classical trope, while at the same time presenting catastrophe in an explicitly dramaturgical manner that transformed the city into a stage of ruination. This was a technique with a common political and medical aim: the return to normality and the preservation of the city from the deleterious effects of pestilence by means of a direct impact of visual works like Nicolas Poussin's 
The Plague of Ashdod (1630-31) or Antonio Zanchi's The Virgin Appears to the Plague-Stricken (1666) on the bodies of their viewers. ${ }^{30}$

By contrast, the re-naturalized city of the pandemic imaginary is not a cathartic landscape of ruination and mourning but of life unbound. It should be noted here that this phantasmagoria of life, where, to use Susan Buck-Morss' formula, the city acts as a dialectical image of both "dreamworld and catastrophe", is structured around a particular ignorance: of the fact that without humans, or a technocratic human society, nuclear factories and industrial infrastructures would quickly break down, creating such levels of toxic waste and radioactivity that nonhuman life would hardly be unaffected. ${ }^{31}$ However, in these scenarios, what Nancy has analyzed as the equivalence between catastrophes in today's world how "the spread and proliferation of repercussions from every kind of disaster hereafter will bear a mark of that paradigm represented by nuclear risk" - is overlooked. ${ }^{32}$ Although post-pandemic cities, like post-nuclear ones, are deserted by humans, they are far from desertified. Instead, they, and indeed the entire globe, are portrayed as "tropicalized". Take for example the visualization of cities in the popular post-pandemic computer game The Last of Us developed by Naughty Dog (2013). ${ }^{33}$ Vegetation and trees aggressively engulf once flagships of industrialism like Pittsburgh; herds of deer graze next to collapsed bridges with cars covered in moss; and, in the iconic finale of the game, the protagonists Joel and Ellie encounter a tower of giraffes in the midst of Salt Lake City. The reflections of a review on this much-discussed scene of the computer game are characteristic: "Nature is claiming back land, animals are emerging once again, all while the human population is slowly dying out; we no longer present an essential force in this world". ${ }^{34}$

It is here that the second contrastive image comes into play. In order to accentuate the image of cities having turned feral, post-pandemic narratives borrow from, and in turn transform, a trope originally belonging not so much to nuclear apocalyptic fantasies but to the iconography of war instead. This is the image of iconic "tropical" animals, like lions or tigers, roaming embattled cities like Sarajevo. The image arose in the context of the post-Cold War visual culture of war, with its function being to reproduce an aestheticized image of conflict as an unreasoned and anomic absurdity. ${ }^{35}$ Compare this image to I Am Legend, where as Will Smith is hunting deer in Times Square, he is confronted by a pride of lions (obviously escaped from the New York Zoo) that capture his prized prey with grace and ease. In its transformed role, wildlife thus comes to connote no longer life besieged by human folly but the triumph of "natural" life as a return of the repressed. ${ }^{36}$ This is not simply a return of the world to nature, but a process embodying life's supposed propensity to naturalize even the most garish artifacts of human civilization, like Times Square. ${ }^{37}$

This post-pandemic image relies on Western, colonial fantasies of the tropics as primeval landscapes: landscapes where supposedly life itself emerged and where life and death are of such intensity that they become indistinguishable. Historians, like David Arnold, have long stressed the persistent relevance of colonial notions 


\section{The post-pandemic condition}

of the tropics and their impact on the way in which we "divide [the world] up in imagination and in practice". 38 "As a conceptual, and not merely physical, space", the tropics have not only operated in juxtaposition with what are considered to be "temperate" areas or zones, but most importantly institute a topology of encounter for "white men and women venturing into an unfamiliar world in which climate, vegetation, disease and people all appeared to be different, and in which the familiar forms of temperate life were threatened, overturned, or inverted". ${ }^{39}$ It was there, that, following Alexander von Humboldt, nature revealed itself in its fullest and most forceful character, making itself available for observation. ${ }^{40}$ Yet what started as a vision of earthly paradise was soon imbued with a sense of ever-present, indeed over-abundant, peril. As Arnold has argued, by the end of the nineteenth century, Darwinian configurations of the tropics as theaters of a never-ending struggle for survival were coupled with a proliferation of ideas (already expressed at the end of the eighteenth century but with only limited impact until the midst of the nineteenth century) that "Some diseases might resemble the fevers of Europe but in the tropics they were 'greatly more violent in their attack, quicker in their progress, and more fatal in their termination' than in Europe (Hunter 1788)" ${ }^{41}$ Recent historical studies of and debates about the genealogy of this transformation, including Patrick Manson's contribution and the differences between British and French imperial visions of the tropics, provide important insights into its social, political, and epistemological drivers. ${ }^{42}$ What is important here, however, is to stress that by the turn of the nineteenth century, at the high noon of the colonial project, the tropics became a contested topos of imperial mastery. ${ }^{43}$ A field where "tropical exuberance" and "tropical enormity" threatened individual well-being and social order and required the development of new ways of rendering intelligible and actionable the environment and the bodies inhabiting it. ${ }^{44}$

This was a vision of the tropics as "the antithesis of civilization": "Though many Victorian naturalists believed that humans originated in the tropics, they argued that only when they migrated to cooler, more stimulating climates, did they develop the habits of civilized life". ${ }^{45}$ If the colonial experience thus entailed an encounter with this imagined-as-originary topos of fecundity, virulence, and death, it also entailed a reverse encounter. This comprised a dramatic engagement between white colonial civilization and the tropics set not in the colonies but in the temperate metropoles instead. Preceding the consolidation of tropical medicine, but finding its institutionalization therein, this vision was structured around a peculiar reciprocity: in return for the spoils of the tropics, Europe and North America had no choice but to receive a host of unwanted stowaways - infectious diseases: "What was imported and distributed as a result of capitalist exchange would, ironically, also result in capitalism's undoing - imploding it from within by producing a collapse, albeit temporary, of economic structures". ${ }^{46}$ Whether these were believed to be germs or miasmas carried (or indeed self-generated) in tropical merchandize and native bodies, "tropical diseases" like yellow fever, cholera, and plague embodied a counter-gift that became an inextricable part of the imperial experience..$^{47}$ 
This trope of what Rod Edmond has called "returning fears" is remobilized in the post-pandemic image of rewilded cities. ${ }^{48}$ But it does so with an added ontological edge. For the pandemic imaginary supplants this colonial, medicalgeographical imagination with the notion that the "tropical" virus, which is usually blamed for the next pandemic, deriving as it does from "the maximum of wilderness", does not simply bring a pathogenic agent of tropical nature back into the temperate zone but rather renders the tropics into a universal ontological condition. ${ }^{49}$ Everything touched by the killer virus (as we will see, with the exception of humans) turns tropical. This metamorphosis is the result of the supposed propensity of the tropics, on the one hand, to bring about an irrepressible abundance, or indeed immanence of life, and, on the other hand, the "lapse of civilization" conceived as the realization of a project for mastery - by leading to its stagnation, degeneration, and decay. ${ }^{50}$

\section{Edenic perdition}

Should we then consider this imaginary process of "tropicalization", taking place as it were "when an emerging infection decides to really show us who's boss", as part of the mythocosmological variant that Déborah Danowski and Eduardo Viveiros de Castro have identified as the return to "wilderness"? ${ }^{51}$ In their examination of the end of the world, the two authors note the persistence of the mytheme of the Edenic world as "a world-without-humans that is a worldfor-humans" - a "pre-objective world of a pre-subjective humankind". ${ }^{52}$ Danowski and Viveiros de Castro follow William Cronon in noting that, in the vast majority of theological thinking before modernity, Eden was not configured as a wilderness but as a "garden", with wilderness being instead an anti-Eden, what surrounded Eden, and the place where Adam and Eve were exiled after the Fall..$^{53}$ It is only within Romanticism and its environmentalist epigones that what used to be the reverse or negative of Eden has come to become identified with it. Eden-as-wilderness is an environmentalist construct "built around a fundamental opposition between life, as inexhaustible profusion of forms and subtle balance of forces, and humankind [. . . imagined as a factor that quantitatively and qualitatively defiles, diminishes, and unbalances life". ${ }^{4}$

Certainly, the idea of life "return[ing], invincible in its variety of abundance, reconquering the territory (the Earth) that humankind, acting like an alien, ruthless invader, had transformed into a desert of concrete, tarmac, plastic, and nuclear waste" pervades not only visions of Earth after humanity, like Alan Weisman's The World Without Us, but also, as we have already seen, the pandemic imaginary. ${ }^{55}$ And yet there is a key difference between the former and the latter. In the case of the post-pandemic condition, while the Edenic realm is reinstituted as a universal condition on Earth, this is not a topology that excludes humans but rather one that includes them (one could go as far as to say engulfs them), albeit denuded of their humanity. It is only through this inclusive exclusion that the planetary "return of the repressed" bars humans, not from Eden itself but from the ecological utopia marked by the categorical merging of Eden and wilderness. ${ }^{56}$ While the entire 
world is transformed and indeed "healed" and "rebalanced" through this merging all becomes Edenic insofar as all becomes wild again via the immanence of tropical life - humans continue to inhabit the world as a species apart. This is for the simple reason that, in this newly rewilded world, humans themselves remain decisively unwild. Whereas all plants and animals seem to be teeming with life and potential, in the post-pandemic world humans appear to be completely devoid of any ability to adapt or reemerge in any socially meaningful way.

It is instructive to compare this image to post-apocalyptic narratives that depict humanity's collapse into what may briefly be coined as a hybrid of "savage" and "barbarian" sociality: nomadic hordes led by charismatic if cruel leaders, engaging in pillage and obscene rituals, in an excess of life in the midst of affective and often sexualized ruins. Such nuclear narratives present us with an anthropological phantasmagoria, where, as Joseph Masco has examined in detail, "the utopian potential and traumatic effects of the nuclear project" are irreducibly interlinked ${ }^{57}$ Masco relies here on Susan Buck-Morss' reading of Walter Benjamin as regards phantasmagorias as nexuses of "technoaesthetics" whose general effect consists in "anaesthetizing the organism, not through numbing, but through flooding the senses" ${ }^{58}$ Still, what Masco aptly coins as "nuclear phantasmagoria" should also be understood in relation to the observation that "phantasmagoria always refers to the inventory of the 'History of Civilization', i.e. of a historical or natural 'authenticity". ${ }^{99}$ Both scientific and popular visions of humankind after the nuclear apocalypse envision humans as relapsing into an originary state, often identified with simplistic images of the Stone Age - a vision that entails a vitalist hope of a return to our existential roots from which we could conceivably reemerge, taking a different pathway than the one we already have, one that can lead us to a realized utopia rather than catastrophe. ${ }^{60}$ The hope, in other words, may be said to rely on a fantasy of nuclear catastrophe as a "second chance", or indeed an ontological time travel - that is, if anyone survives to embark on it - at whose heart lurks a "decision" of anthropogenic proportions.

By contrast, to return to the example with which we started our examination of rewilding, in Boyle's short story, the protagonist reflects on the latter trope explicitly and "confesses" that he has "never been a fan of the apocalyptic potboiler, the doomsday film shot through with special effects and asinine dialogue or the cyberpunk version of a grim and relentless future" ${ }^{61}$ For him, what this genre had led us to expect did not materialize "after the plague": "There were no roving gangs - they were all dead, to a man, woman and tattooed punk". ${ }^{62}$ What characterizes the survivors instead is their inability to "organize anything, either for better or worse". ${ }^{63}$

Thus, the physical and indeed ontological transformation of the world marked by the next pandemic leaves humankind's being in a state of double exclusion: no longer subjects of mastery (including having access to another's or another form of mastery) but also not natural or "wild" - that is, neither able to (re)build civilization nor capable of inhabiting the world like animals. In what Philippe Descola has described as the naturalist ontology pervading our technoscientific societies, this amounts to falling into a true ontological gap: humankind no longer 
has access to culture (that makes nature intelligible and actionable) nor, however, does it participate in a return to nature, marked by the immanence of life, like the world around it.

If there is a word for this gap, this endless double-exile, this is oblivion. This should not be confused with images of forgetting, which pervade pandemic ends of the world in the age before "emergence", like Jack London's The Scarlet Plague. There we encounter a conflict between survivors of the "plague" who remember the "world before" and a generation brought up after the collapse, for which anything pertaining to that world makes no sense and is indeed unthinkable. In Jack London's case, this appears to be linked with the rapid degeneration of language among the young generation: "They spoke in monosyllables and short jerky sentences that was more a gibberish than a language. And yet, through it run hints of grammatical construction, and appeared vestiges of the conjugation of some superior culture". ${ }^{64}$ In this Spenglerian vision, humanity has turned feral, reacquiring the supposed linguistic characteristics of what anthropological thinking at the time considered to be "savages": "Strange it is to hear the vestiges and remnants of the complicated Aryan speech falling from the lips of a filthy skin-clad savage". ${ }^{65}$ This is a racist, authority-longing narrative. ${ }^{66}$ "With the coming of the Scarlet Death", Jack London's protagonist tells us, "the world fell apart, absolutely, irretrievably. Ten thousand years of culture and civilization passed in the twinkling of an eye, 'lapsed like foam "' ${ }^{67}$ It is instructive to compare this narrative of the future savage with images of the post-pandemic condition in circulation today, for at first sight there appears to be a moment of recognition. This is, for example, evident in the concluding remarks of Tony Robinson's Foreword to the 2008 Hesperus edition of The Scarlet Plague, where the British actor notes:

Last week I saw a post-apocalyptic blockbuster in which, following a worldwide plague, our gaunt hero strides through the empty streets of New York. Central Park has become a savannah, wild deer bound across the streets, the only other survivors are disease-ridden mutants. The spirit of Jack London is still alive! ${ }^{68}$

\section{But is it?}

In London's book, the plague equates, one may even say levels, humanity with nature. As a result, the former's primordial instincts are released and humans abandon the corset of civilization to embrace life itself once again. This is not the case for I Am Legend, which is the movie Tony Robinson is presumably referring to, or the pandemic imaginary more generally. Here humanity is not re-animalized, nor does it return to a feral, vitalistic state of savagery - a new being replete with the excess of life, to the point of its Social Darwinistic identification with death. ${ }^{69}$ This marks the logical conclusion of naturalist ontology, and as such it is revealing of the latter's anthropocentric exceptionalism. For so distinct are humans held to be from other life forms, and from "nature" itself, that even when everything, including Times Square, has become naturalized, humans fail to also become part 
of nature, as a topos where life and the world coincide. This is configured as a "natural" failure rather than simply as a wrong "cultural" decision and is thus irreversible and inescapable.

As a result, post-pandemic humans are not future savages inhabiting some ecological, tropicalized Eden..$^{70}$ Instead, as was already discussed in Chapter 4, post-pandemic humankind resembles more the prehumans of Aeschylus' Prometheus Bound: creatures roaming the Earth "just as shapes in dreams"; beings "abandoned to chance". Hence, in contrast to London's book, in post-pandemic visions like the one developed in Emily St. John Mandel's popular and critically acclaimed novel Station Eleven, oblivion among the survivors of the next pandemic (the "Georgian Flu", in this case) is not an index of a collapse or relapse into savagery. ${ }^{71}$ It rather marks a fall of humanity characterized by its inability to distinguish and act upon the real:

In the ensuite bedroom Kristen closed her eyes for just one second as she flipped the light switch. Naturally nothing happened but always in these moments she found herself straining to remember what it had been like when this motion had worked: walk into a room, flip a switch and the room floods with light. The trouble was she wasn't sure if she remembered or only imagined remembering this. ${ }^{72}$

We are thus faced with an existence that is pervaded by what in the same novel is referred to as "the meaning of emptiness" - something not referring simply to depopulated Earth or urban terrain, but more pertinently to the idea that humanity has been emptied of its autopoetic agency: the techne to recreate itself through its relation to the world following the latter's end as a world for one's self. ${ }^{73}$

Two elements may then be said to form the cornerstone of the post-pandemic condition in the pandemic imaginary, bringing us back to our interlinked questions regarding what remains after the next pandemic and what is made possible by it:

1 humankind's incapacity to conceive and refashion its relation with the world as intelligible and actionable.

2 humankind's incapacity to reinvent itself by turning collapse into an opportunity for a new way of being.

These traits (the first relational, the second ontological) are moreover recursively linked, so they are presented as irreducible causes and effects of each other. It is this, rather than the traits in themselves or in their sum, that forms the metaphysical core of dominant configurations of humanity after the next pandemic.

\section{Emergence barred}

Within the realm of the instituted pandemic imaginary, the next pandemic thus signals not simply the end of mastery but the end of humanity's ability to reimagine and reinstitute what it is to be human for the simple reason that, in turn, 
humanity's mastery of its relation with the world is supposed to be a sine qua non of any imaginable being-human. Ontogeny is thus rendered impossible without mastery. ${ }^{74}$

Here then lies the instituting paradox of the pandemic imaginary: on the one hand, the idea of a pandemic-borne human extinction relies on an understanding of the formation of new pathogens as a process of emergence, on the other hand, the result of the next pandemic is identified with humanity's interdiction from emergence and re-emergence as an anthropological process. If we want to condense this into a formula, we would say that the next pandemic is an event where biological emergence leads to the end of anthropological emergence. In this way, not only is the post-pandemic condition devoid of what Riffel has called the kairos of the post-apocalypse - "a chance to seize new relations of ethics, kinship, and life" - it is also a state of ontological suspension. ${ }^{75}$ For it renders self-institution no longer an inherent trait of the human condition but instead a contingent capacity that under certain conditions may be lost, leaving humans without their humanity. This has a radical, ontological impact. Denying autopoetic capacity as an inherent and indeed foundational trait of being human, the pandemic imaginary suspends humankind from the two key poles of its existential coherence. First, humankind is suspended from the realm of nature, where, by contrast, emergence is accepted by the very proponents of next pandemic scenarios as an irreducible process of speciation. Second, humankind is suspended from history, or more precisely from what Cornelius Castoriadis defines as the social-historical: "the ontological form that can put itself into question and, through self-reflective activity, explicitly alter itself' ${ }^{76}$ This is not merely a barring of humankind from its ability to selforganize, in the sense of being able to pick up what remains of itself after the pandemic collapse so as to reassemble some form of social organization. Rather it marks the suspension of humankind from the "ontology of human creation", of self-creation (autopoiesis) as the core of its species-being. ${ }^{77}$

Returning then to the key question of this chapter, regarding whether the postpandemic condition affords a radical new concept of that it is to be human, we may say that, in its instituted reality, the former points out at a profound "crisis in the instituting social imaginary" of the societies presently engaged in the pandemic imaginary. ${ }^{78}$ For the inability to imagine a post-pandemic humankind capable of conceiving itself as other than - that is to say, other than as a project for mastery underlines an inability both to unthink mastery and to pose "the question of history [as] the question of the emergence of radical otherness". ${ }^{79}$ In other words, as a component of the pandemic imaginary, the post-pandemic condition fails to promote images, understandings, or anticipations contributing to the overcoming of the instituted imaginary regarding the human condition. And, at the same time, it also fails to give rise to or confirm a vision of humankind as a species whose ontology is irreducibly one of becoming and, moreover, of becoming-other. It may thus be said that as an instituted imaginary the pandemic imaginary delimits the "potentiality of the human being", in the sense defined by Castoriadis: as "the potentiality of potentiality", that is, the ability to create a critical reflection on one's ontological conditions that allows the self to become other. ${ }^{80}$ 


\section{Notes}

1 James Berger, After the End: Representations of Post-Apocalypse (Minneapolis: University of Minnesota Press), xi.

2 Berger, After the End, 6.

3 Berger, After the End, 5.

4 For an examination of the Amerindian example, see: Déborah Danowski and Eduardo Viveiros de Castro, The Ends of the World, translated by Rodrigo Nunes (Cambridge: Polity Press).

5 Berger, After the End, 7.

6 Berger, After the End, 10.

7 Casey R. Riffel, "Animals at the End of the World: Notes toward a Transspecies Eschatology," In Making Animal Meaning, eds. Linda Kalof and Georgina M. Montgomery, pp. 159-172 (East Lansing: Michigan State University Press, 2011), 160.

8 Joshua Schuster, "Life after Extinction," Parrhessia 27 (2017), 92.

9 Darwin in Schuster, "Life after Extinction," 88-89.

10 Schuster, "Life after Extinction," 92.

11 Julietta Singh, Unthinking Mastery: Dehumanism and Decolonial Entanglements (Durham, NC: Duke University Press, 2017), 12, 13. As is, however, obvious in my approach of mastery, this is quite distinct from the Hegelian interpretation of the term accepted by Singh.

12 Evan Calder Williams (2011) has discussed the similarity of the latter image with JeanLuc Godard's apocalyptic traffic jam in the Weekend (1967). On the wider imaginary of Manhattan bridges from an anthropological perspective, see: Andrew Irving, "Granite and Steel," In Reflections on Imagination: Human Capacity and Ethnographic Method, eds. Mark Harris and Nigel Rapport, pp 135-160 (Farnham: Ashgate, 2015). On crime and anomy as the collapse of sovereignty at the end of the world, see: Majit Yar, Crime and the Imaginary of Disaster: Post-Apocalyptic Fictions and the Crisis of Social Order (London: Palgrave Macmillan, 2014).

13 Guillermo del Toro and Chuck Hogan, The Strain, Season 1, Episode 1, "Night Zero," July 13, 2014.

14 Thomas Coraghessan Boyle, After the Plague (New York: Viking Press, 2011), 281.

15 Boyle, After the Plague, 290.

16 Boyle, After the Plague, 296, 297.

17 Boyle, After the Plague, 290-291. Indeed in "emergence" narratives the leap from the jungle seems to be not simply an accident but the manifest destiny of zoonotic viruses: "That's a critical issue for us as we think about the next global pandemic. Which one gets to say, 'Hey, I made the jump. I never have to go back to the jungle again, slumming inside rodents"" (Khan \& Patrick, 2016: 84). For a genealogy of the jungle in colonial tropical mentality, see: David Arnold, The Tropics and the Traveling Gaze: India, Landscape, and Science, 1800-1856 (Washington, DC: The University of Washington Press, 2006).

18 Logan Hill, "How to Build a True Urban Jungle," New York Magazine (undated), accessed August 22, 2017 http://nymag.com/movies/features/41551/

19 Hill, "How to Build a True Urban Jungle." Indeed, so popular was the "urban jungle" image of Will Smith hunting deer in Times Square that a Google Maps hack in 2014 turned any Street View of your choice into a post-pandemic cityscape; Amanda Cooser, "Google Maps Hack Turns Any Street View into an Urban Jungle," CNET, March 19, 2014, accessed June 10, 2017 www.cnet.com/news/google-maps-hackturns-any-street-view-into- an-urban-jungle/ At the same time, Sony generated images showing "the destruction that could happen to key UK landmarks if humanity was to be struck by the 'Cordyceps virus' as it does in The Last of Us" post-pandemic videogame; John Anderson, "Images Show What Could Happen If Britain Was Hit by the 
Last of Us Virus," ShopTo, June 13, 2013, accessed October 2, 2017 www.shopto.net/ news/43167/Images-show-what-could-happen-if-Britian-got-The-Last-of-Us-virus

20 Valerie Kuletz, The Tainted Desert: Environmental Ruin in the American West (London and New York: Routledge, 1998); John Wills, "'Welcome to the Atomic Park': American Nuclear Landscapes and the 'Unnaturally Natural'," Environment and History 7(4) (November 2001): 449-472; Catrin Gersdorf, The Poetics and Politics of the Desert: Landscape and the Construction of America (Amsterdam: Rodopi, 2008). For a broader discussion of "nuclear iconography", see: Bryan C. Taylor, "'Our Bruised Arms Hung Up as Monuments': Nuclear Iconography in Post-Cold War Culture," Critical Studies in Media Communication 20(1) (2003): 1-34; Bryan C. Taylor, "Nuclear Pictures and Metapictures," American Literary History 9(3) (Autumn, 1997): 567-597; Peggy Rosenthal, "The Nuclear Mushroom Cloud as Cultural Image," American Literary History 3(1) (Spring, 1991): 63-92.

21 Matilde Nardelli, "No End to the End: The Desert as Eschatology in Late Modernity," Tate Papers 22 (Autumn 2014) www.tate.org.uk/research/publications/tate-papers/22/ no-end-to-the-end-the-desert-as- eschatology-in-late-modernity

22 Malcolm Bull, "On Making Ends Meet," In Apocalypse Theory and the Ends of the World, ed. Malcolm Bull, pp. 1-17 (Oxford: Oxford University Press, 1995).

23 Max Page, The City's End: Two Centuries of Fantasies, Fears, and Premonitions of New York's Destruction (New Haven: Yale University Press, 2019).

24 Evan Calder Williams, Combined and Uneven Apocalypse (Hants: Zero Books, 2011), 160.

25 Yael Navaro-Yashin, "Affective Spaces, Melancholic Objects: Ruination and the Production of Anthropological Knowledge," Journal of the Royal Anthropological Institute N.S. 15(1) (2007): 1-18; Joseph Masco, “"Survival Is Your Business': Engineering Ruins and Affect in Nuclear America," Cultural Anthropology 23(2) (May 2008): 361-398.

26 This trope reaches its ironic conclusion in the first movie of the original The Planet of the Apes saga (1968), where the human hero is presented with these ruins (including a talking doll) by the apes that have replaced humanity as the master species on the planet. In turn, a dialogue between the image of the desert and that of the ruinous city is palpable in these narratives, perhaps with the most daring juxtaposition being attempted by Luis Bunuel in his film Simon of the Desert (1965), where the fifthcentury Desert Father finally encounters the end of the world in the form of a rock $n$ roll club in 1960s New York City - an anthropological ruin of commodities and exchange values where youth is dancing the "final dance" called "radio-active flesh".

27 Jean-Luc Nancy, After Fukushima: The Equivalence of Catastrophes (New York: Fordham University Press, 2015), 56; see also p. 7 for further discussion of catastrophe and Greek tragedy. For a discussion of whether "the end of the world" qualifies as a catastrophe, see: Michaël Fœssel, et al., "La catastrophe est-elle une politique?," Esprit 374(5) (May 2011): 54-70.

28 Rachel Bruzzone, "Polemos, Pathemata, and Plague: Thucydides' Narrative and the Tradition of Upheaval," Greek, Roman, and Byzantine Studies 57 (2017): 889, 894.

29 This is extensively examined in contributions to Bachvarona and Dutch's volume on the fall of cities; see especially: Mary R. Bachvarona and Dorota Dutsch, "Mourning a City 'Empty of Me': Stereotypes of Anatolian Communal Lament in Aeschylus' Persians," In The Fall of Cities in the Mediterranean: Commemoration in Literature, Folk-Song, and Liturgy, eds. Mary R. Bachvarona and Dorota Dutsch, pp. 79-105 (Cambridge: Cambridge University Press, 2017).

30 This impact was premised on humoral understandings of the human body at the time; Shelia Barker, "Poussin, Plague, and Early Modern Medicine,"The Art Bulletin 86(4) (2004): 659-689; Jennifer Gear, "Performing Plague: Antonio Zanchi and the Dynamics of Spectatorship at the Scuola Grande di San Rocco in Venice," Renaissance 


\section{The post-pandemic condition}

Studies (2017) doi:10.1111/rest.12360 We should not, however, relapse into a functionalist understanding of the theme here, for the latter also persisted in contexts where it appeared to lack any specific social purpose; see, for example, its persistence in Byzantine and Ottoman plague-related literature (Varlik 2015).

31 Susan Buck-Morss, "The City as Dreamworld and Catastrophe," October 73 (Summer, 1995): 3-26.

32 Nancy, After Fukushima, 3.

33 The success of The Last of Us has led the Wellcome Trust to produce a series of videos on the "science" of the videogame, e.g., Wellcome Trust, "What Do We Do If a Pandemic Happens? The Science of the Last of Us," YouTube, September, 26, 2016, accessed October 10, 2017 www.youtube.com/watch? $\mathrm{v}=\mathrm{krnPbgMZdHI}$ This is one of several computer games dedicated to either halting, spreading, or surviving a pandemic. For an analysis of the latter, see: Lorenzo Servitje, "H5N1 for Angry Birds: Plague Inc., Mobile Games, and the Biopolitics of Outbreak Narratives," Science Fiction Studies 43(1) Digital Science Fiction (March 2016): 85-103. Indeed, as the CDC's entanglement with video games culture makes evident, the affinity between epidemiology and video games seems to be mutual. In his recent book on the next pandemic (Khan and Patrick 2016: 249), the PHPR ex-director of the CDC, actually presents viruses as video game players: "In this cycle of mutation and transmission, microbes are like players advancing to new levels in a video game until they have an overwhelmingly potent set of new weapons to make them invincible". For a broader examination of the end of the world and pandemic video games, see: Stephen J. Webley, "Wondering the Digital Wonderlands: The Interactive Images and Legends of Disaster: Desire and Ideology in Post-Apocalyptic Videogames," In Apocalyptic Chic: Visions of the Apocalypse and Post-Apocalypse in Literature and Visual Arts, eds. Barbara Brodman and James E. Doan, pp. 211-228 (Madison: Fairleigh Dickinson University Press 2018).

34 Mark Thompson, "The Last of Us: 3 Key Observations to Understand the Ending," What Culture, November 30, 2013, accessed October 2, $2017 \mathrm{http}: / /$ whatculture.com/ gaming/last-us-3-key-observations-understand-ending

35 The fascination with zoo animals in besieged cities is evident from reportage on the ongoing war in Syria. See, for example: Joel Williams, "These Zoo Animals Survived the Battle to Retake Mosul from ISIS," CNN, February 3, 2017 http://edition. cnn.com/2017/02/02/middleeast/iraq-mosul-zoo-animals-trnd/index.html Sahar Zand, "The Animals Rescued from War Zones," BBC News, August 31, 2017 www.bbc. co.uk/news/av/world-middle-east-41104849/the-animals-rescued-from-war-zones; Anon., “1992: Sarajevo's Zoo in Wartime', CNN, May 22, 2014 http://edition.cnn. com/videos/world/2014/05/22/pkg-1992-amanpour-bosnia-sarajevo-zoo.cnn; Michael Holmes, "Baghdad Zoo: A Different Battle," CNN, April 17, 2003 http://edition.cnn. com/2003/WORLD/meast/04/16/sprj.nilaw.baghdad.zoo/ For a fictional work on this theme as applied to WWII and the 1990s wars in Yugoslavia, see: Emir Kusturica's film Underground (1995).

36 In Terry Gilliam's Twelve Monkeys (1995), post-pandemic New York is populated by a host of bears, lions, tigers etc., but only because these were liberated by the homonymous animal rights group at the same time as the killer virus struck the world.

37 Representations of the post-pandemic condition can also take a cautionary character, like it is the case in Margaret Atwood's pandemic trilogy; for discussion, see: Paul L. McEuen, "Science Fiction: A Post-Pandemic Wilderness," Nature 500(398-399) (August 22, 2013) doi:10.1038/500398a

38 David Arnold, "The Place of 'the Tropics' in Western Medical Ideas since 1750," Tropical Medicine and International Health 2(4) (April 1997), 303.

39 Arnold, "The Place of 'the Tropics' in Western Medical Ideas since 1750," 305.

40 Arnold, "The Place of 'the Tropics' in Western Medical Ideas since 1750," 306.

41 Arnold, "The Place of 'the Tropics' in Western Medical Ideas since 1750," 307. 
42 The extent of this corpus is such that only some key publications may be mentioned here: Warwick Anderson, Colonial Pathologies: American Tropical Medicine, Race, and Hygiene in the Philippines (Durham, NC: Duke University Press, 2006); Michael Osborne, "Acclimatizing the World: A History of the Paradigmatic Colonial Science," Osiris 15 (2000): 135-151; Randall M. Packard, The Making of a Tropical Disease: A Short History of Malaria (Baltimore: The Johns Hopkins University Press, 2007); Julyan G. Peard, Race, Place and Medicine: The Idea of the Tropics in 19th Century Brazilian Medicine (Durham, NC: Duke University Press, 1999); Douglas M. Haynes, Imperial Medicine: Patrick Manson and the Conquest of Tropical Disease (Philadelphia: University of Pennsylvania Press, 2001); Alison Bashford, "Is White Australia Possible? Race, Colonialism and Tropical Medicine," Ethnic and Racial Studies 23 (2000): 248-271; Pratik Chakrabarti, Bacteriology in British India: Laboratory Medicine and the Tropics (Rochester, NY: University of Rochester Press, 2012); Mark Harrison, "Tropical Medicine in Nineteenth-Century India," British Journal for the History of Science 25 (1992): 299-318; Michael A. Osborne, The Emergence of Tropical Medicine in France (Chicago: The University of Chicago Press, 2014).

43 For recent works examining the development of this form of mastery, see: Beth Fowkes Tobin, Colonizing Nature: The Tropics in British Arts and Letters, 1760-1820 (Philadelphia: University of Pennsylvania, 2004); Amar Wahab, Colonial Inventions: Landscape, Power and Representation in Nineteenth- Century Trinidad (Cambridge: Cambridge Scholars Publishing, 2010); Jiat-Hwee Chang, A Genealogy of Tropical Architecture: Colonial Networks, Nature and Technoscience (London and New York: Routledge, 2014); Corey Ross, "Tropical Nature as Global Patrimoine: Imperialism and International Nature Protection in the Early Twentieth Century," Past \& Present 226 (Issue Suppl. 10) (January 2015): 214-239; James. S. Duncan, In the Shadows of the Tropics: Climate, Race and Biopower in Nineteenth Century Ceylon (London and New York: Routledge, 2007).

44 Nancy Leys Stepan, Picturing Tropical Nature (London: Reaktion Books, 2001).

45 Arnold, "The Place of 'the Tropics' in Western Medical Ideas since 1750," 310.

46 Stephanie Boluk and Wylie Lenz, "Infection, Media, and Capitalism: From Early Modern Plagues to Postmodern Zombies," Journal for Early Modern Cultural Studies 10(2) (Fall/Winter 2010), 135.

47 Mark Harrison, Contagion: How Commerce Has Spread Disease (New Haven: Yale University Press, 2012). For an analysis of the entangled miasmatic and germ epistemologies of this imaginary, see in particular the recent work of David Barnes: David S. Barnes Cargo, "Infection,' and the Logic of Quarantine in the Nineteenth Century," Bulletin of the History of Medicine 88(1) (2014): 75-101; David S. Barnes, "'Until Cleansed and Purified': Landscapes of Health in the Interpermeable World," Change Over Time 6(2) (Fall 2016): 138-152.

48 Rod Edmond, "Returning Fears: Tropical Disease and the Metropolis," In Tropical Visions in an Age of Empire, eds. Felix Driver and Luciana Martins, pp. 175-194 (Chicago: The University of Chicago Press, 2005).

49 Kelly Enright, The Maximum of Wilderness: The Jungle in the American Imagination (Charlottesville: Virginia University Press, 2012). Characteristically, in such real-life cases (that is to say all of them) when viruses fail to bring about the end of the world, they are often depicted as returning or "reced[ing] into the jungle" (Khan \& Patrick 2016: 59). For comparative "colonial tropes in apocalyptic thinking", see: Mary Manijikian, Apocalypse and Post-Politics: The Romance of the End (Lanham: Lexington Books, 2012).

50 Arnold, The Tropics and the Traveling Gaze, 82. See also: Edmond, "Returning Fears: Tropical Disease and the Metropolis". On the relation between degeneration and the fear of infectious diseases from the tropics, see also: Christos Lynteris, "Yellow Peril Epidemics: The Political Ontology of Degeneration and Emergence," In Yellow Perils: 


\section{The post-pandemic condition}

China Narratives in the Contemporary World, eds. Frank Billé and Soren Urbansky 35-59 (Honolulu: Hawaii University Press, 2018).

51 Ali Khan and William Patrick, The Next Pandemic: On the Front Lines against Humankind's Gravest Dangers (New York: PublicAffairs 2016), 244.

52 Danowski and Viveiros de Castro, The Ends of the World, 21.

53 William Cronon, "The Trouble with Wilderness: Or, Getting Back to the Wrong Nature," Environmental History 1(1) (January 1996): 7-28. For a detailed genealogy of Eden as garden and wilderness, see: Carolyn Merchant, Reinventing Eden: The Fate of Nature in Western Culture (London and New York: Routledge, 2003). For the way in which it has been visualized, see: Alessandro Scafi, Mapping Paradise: A History of Heaven on Earth (London: The British Library, 2006).

54 Danowski and Viveiros de Castro, The Ends of the World, 25.

55 Danowski and Viveiros de Castro, The Ends of the World, 25; Alan Weisman, The World Without Us (London: Virgin Books 2007). The creators of The Last of Us, for example, have reflected on the influence of the book on their depiction of post-pandemic cities. Ben Hanson, "The Story and Environments of the Last of Us," Gameinformer, February 8, 2012, accessed October 2, 2017 www.gameinformer.com/b/features/archive/ 2012/02/08/the-story-and-environments-of-the-last-of-us.aspx

56 Hence, contra Pierre-Henri Castel (2018), these visions of the end having a different structural position in our anthropological imaginary than inclusive nature-bound utopias developed in philosophical and political writing since the Renaissance.

57 Joseph Masco, The Nuclear Borderlands: The Manhattan Project in Post-Cold War New Mexico (Princeton, NJ: Princeton University Press, 2006), 15.

58 Susan Buck-Morss, "Aesthetics and Anaesthetics: Walter Benjamin's Artwork Essay Reconsidered," October 62 (Autumn 1992), 22.

59 Marc Berdet, "Eight Thesis on Phantasmagoria," Anthropology \& Materialism 1 (2013) https://am.revues.org/225\#toctoln3

$60 \mathrm{See}$, for example, the way in which these narratives allow for reconceptualizations of agency in: Yannick Rumpala, "Que faire face à l'apocalypse? Sur les représentations et les ressources de la science-fiction devant la fin d'un monde," Questions de Communication 30 (2016): 309-334.

61 Boyle, After the Plague, 293.

62 Boyle, After the Plague, 293.

63 Boyle, After the Plague, 293.

64 Jack London, The Scarlet Plague (Croydon: Hesperus Press, 2013), 14.

65 London, The Scarlet Plague, 62.

66 See also London's short story "The Unparalleled Invasion" for a eugenicist vision of germ warfare as racial purification. For analysis, see: Elana Gomel, "The Plague of Utopias: Pestilence and the Apocalyptic Body," Twentieth Century Literature 46(4) Literature and Apocalypse (2000): 405-433; John N. Swift, "Jack London's "The Unparalleled Invasion': Germ Warfare, Eugenics, and Cultural Hygiene," American Literary Realism 35(1) (Fall 2002): 59-71.

67 London, The Scarlet Plague, 32.

68 Tony Robinson, "Foreword," In London, The Scarlet Plague, viii.

69 For studies drawing a broader comparison between late nineteenth/early twentieth century and contemporary epidemic fears, see: Boluk and Lenz, "Infection, Media, and Capitalism: From Early Modern Plagues to Postmodern Zombies"; Lynteris, "Yellow Peril Epidemics: The Political Ontology of Degeneration and Emergence"; Nancy Tomes, "Epidemic Entertainment: Disease and Popular Culture in Early-TwentiethCentury America," American Literary History 14(4) (Winter 2002): 625-652; Nancy Tomes, "The Making of a Germ Panic: Then and Now," American Journal of Public Health 90(2) (February 2000): 191-198.

70 Candace Slater, "Amazonia as Edenic Narrative," In Uncommon Ground: Rethinking the Human Place in Nature, ed. William Cronon (New York: W.W. Norton \& Co, 1996). 
71 Station Eleven's Picador paperback cover rhymes with the rewilding theme discussed above, showing the drawing of deer roaming in an empty high-rise city. For a broader analysis of the novel, see: Pieter Vermeulen, "Beauty That Must Die: Station Eleven, Climate Change Fiction, and the Life of Form,"Studies in the Novel 50(1) (Spring 2018): 9-25.

72 Emily St. John Mandel, Station Eleven (London: Picador, 2014), 150.

73 Mandel, Station Eleven, 192. It is worth noting here that whereas in Cold War postapocalyptic imaginaries technology destroys biological life, in pandemic scenarios biological life destroys techne.

74 This is a narrative that is entangled with a popular view of societal collapse as a terminal process. Against this image, as it has been cultivated by works like Jared Diamond's bestseller Collapse (2005), archaeologists have recently promoted scientific understandings of societal collapse as at once a destructive and a generative phenomenon. In particular, in a letter to Science, Harvey Weiss and Raymond S. Bradley (2001: 609-610) have argued that collapse is "an adaptive response to otherwise insurmountable stresses". For a recent review of epidemics and collapse in historical literature, see: Ian Morris, "Plagues and Socioeconomic Collapse," In Plagues, eds. Jonathan L. Heeney and Sven Friedemann, pp. 136-167 (Cambridge: Cambridge University Press, 2017).

75 Riffel, "Animals at the End of the World," 166.

76 Cornelius Castoriadis, Figures of the Thinkable, translated by Helen Arnold (Stanford, CA: Stanford University Press, 2007), 226. It should be noted here that while in his dialogue with Francisco Varela, Castoriadis (2011: 68) expressed his dislike for the notion of "emergence", he in fact often used it in his own writings on self-creation.

77 Laurent Van Eynde, "La pensée de l'imagination de Castoriadis du point de vue de l'anthropologie philosophique," In L'imaginaire selon Castoriadis. Themes et enjeux, eds. Sophie Klimis and Laurent Van Eynde (Brussels: Facultes Universitaires SaintLouis, 2006), 67, my translation.

78 Castoriadis, Figures of the Thinkable, 71.

79 Cornelius Castoriadis, TheImaginary Institution of Society (Cambridge: MIT Press, 1998), 172.

80 Paul Ricoeur and Cornelius Castoriadis, "Dialogue on History and the Social Imaginary," In Ricoeur and Castoriadis in Discussion: On Human Creation, Historical Novelty and the Social Imaginary, ed. Suzi Adams, pp. 3-20 (Lantham: Rowman and Littlefield, 2017), 11. 


\section{Conclusion}

\section{Catastrophism beyond closure}

A turn of phrase variously attributed to Fredric Jameson or Slavoj Žižek is often repeated in treatises about the end of the world: "It is easier to imagine the end of the world than the end of capitalism". ${ }^{1}$ It is true that, as an instituted imaginary, the pandemic imaginary appears to be reproducing a vision of humanity enclosed between two imaginable futures: the continuation of the capitalist present and a fall into a state of listless anomy - capitalisme ou barbarie. However, this study has resisted following the analytical pathway of this formula. This is because doing so would be disorienting from an approach of the imaginary that sees it not simply as some trick, fiction, or technique of power but as the continuous, instituting capacity at the foundations of being social. To say that imaginations of the end of the world are an attribute of what Mark Fisher has called "capitalist realism" that is, "the widespread sense that not only is capitalism the only viable political and economic system, but also that it is now impossible even to imagine a coherent alternative to it" - would be to misrecognize the actual, political ontology of the imaginary and its operation in human societies as being merely ideological. ${ }^{2}$

What we may call normative catastrophism - such as this book has shown to be carried over in a wide range of scientific, entertainment, and philosophical significations and practices - has been recently (if perhaps unintentionally) succinctly summarized in an article in The Guardian about the persistent lure of "Apocalypse TV":

We know what happens when the world ends. Well, we've seen it on TV. The Walking Dead shows how our most primal forms emerge as survival eclipses existence. Societal collapse ignites our desire for normality, à la The Stand. Vultures swoop down, aiming to refashion what's left in their own image, as we see on Under the Dome. And, like The Leftovers' Kevin and Nora, we ask why we were spared, and whether or not that makes us the lucky ones. ${ }^{3}$

And yet, when it comes to the "next pandemic", as an event posing an existential risk to humanity, a more nuanced approach linking instituted imaginaries of the end of the world with a "loss" particular to our present social predicament becomes necessary. 


\section{Losing the world}

In his critique of "apocalyptic reason", the French philosopher Michaël Fœssel has argued that "the only philosophically serious sense of the end of the world is that which envisages it under the horizon of its loss". ${ }^{4}$ Fossel (who follows Lawrence Buell in taking the end of the world to be "a metaphor for the present") proceeds from Günther Anders' syllogism that we live in a "humanity for which the 'world' and the experience of the world have lost any value". ${ }^{5}$ Hence, for Fœssel, the fear or anticipation of the end of the world relies, in the first place, in an experience "of loss in the world": "We are afraid of the end of the world because it has already begun and is repeated daily in an environment where technique and the particular type of dispossession, of which it is the instrument, reign". ${ }^{6}$ Fossel thus underlines that this experience of loss is, as Walter Benjamin had already noted, linked to a loss of experience, in the sense that what is lost is not the world as such but our ability, as human subjects, to have a meaningful impact on the world; what Fœssel calls "faire monde" or our capacity to "make world". 7

This may sound paradoxical, or even scandalous, in a time where notions of the Anthropocene, as an age when our planet's very geology is supposed to be formed by human activity, are becoming hegemonic in academia through their investment with sentiments of urgency and opposition, if not outright despair. Yet Fœssel's notion of loss is not necessarily contradictory to these readings, for it is a loss that concerns not humankind as a whole but human subjects as individuals or collectives confronted with and enclosed by a (fetishized and hence alienated) social relation of their own making: capital. As an end of a capacity, rather than of a thing, the end of the world marks for Fœssel a platform for thinking about the present; a process freed from both the object-oriented metaphysics of Anthropocene narratives (reaching their climax in Timothy Morton's recent works) and the biopolitics of urgency present in existential risk thinking, including Jean-Pierre Dupuy's call for an "enlightening catastrophism". 8

While maintaining a focus on dispossession or alienation, what becomes pertinent in this approach of the "end" is to understand how the loss in the world (as a loss for the capacity to "make world") depends on a pervasive "return of the theme of 'life' in the political as well as in the theoretical field". ${ }^{9}$ For Fœssel this "imperative of conserving life" constitutes the pivot of normative catastrophism:

The alternative between life and the world may seem abstract compared to the social and ecological issues facing humanity today. Yet we need to return to it if we want to prevent catastrophism from imposing itself as the only answer to the promises that modernity has not been able to keep. To make a world rather than abandon oneself to the flow of life, to choose the horizon of the possible against the automatic deployment of life, to reinvest the modern project of 'making world' without yielding to the vitalism of security and 
ecology: such could be the call of this reflection which is also a contribution to a new cosmopolitanism. ${ }^{10}$

Developed fully in his book, Après la fin du monde [After the End of the World], the idea of an opposition between world and life leads Fœssel to conclude that the "imperative of life" in the face of the end of the world results in the perpetuation of a social desire for "immunization", in Roberto Esposito's sense of the term. ${ }^{11}$ A desire, Fœssel notes, that is underlined by "an obsession for the survival of identity" and that in turn puts in place and legitimates security and biosecurity apparatuses against future catastrophes.

In critiques of "capitalism realism", imagining the end of the world functions as little more than an ideological smokescreen preventing us from realizing that what, in fact, we cannot imagine is an alternative to capitalism. By contrast, in Fœssel's work what he calls "apocalyptic reason" is the result of the actual loss in the world - a process that, in turn, puts in place biopolitical apparatuses of "immunity" that perpetuate this loss. Hence, Fœssel's affinity with Jean-Luc Nancy's critique of catastrophe is related to "the dissipation of any vision of a "true humanity". ${ }^{12}$ "The possibility of representing a 'total" human, free from alienation, and emancipated from all natural, economic, and ideological subjection", Nancy writes, "has faded away in the very progress of general equivalence becoming the equivalence and interconnection of all goals and all possibilities". ${ }^{13}$ Nancy here refers explicitly to "general equivalence" in the Marxist sense of the term: as a regime of value that "absorbs, well beyond the monetary and financial sphere but thanks to it and with regard to it, all the spheres of existence of humans, and along with them all things that exist". ${ }^{14}$ Hence, for Nancy, "catastrophes have become equivalent because they all derive from the same catastrophe: the civilization of equivalence that imposes capitalism as destiny". ${ }^{15}$ In other words, the end of the world in the form of an evental catastrophe (or chain of catastrophes) is seen by Nancy as the result of the world having already been lost to capital/capitalism, in the sense that the former has become indistinct from the latter both as a globalized social relation and as a geological process.

In these philosophical critiques of the end of the world, we can thus identify two approaches that converge on the shared appreciation of the significance of "loss", without, however, succumbing to what Walter Benjamin called "left melancholia" - a form of analytical conformism that often haunts studies of extinction under the umbrella of the Anthropocene. ${ }^{16}$ On the one hand, in Nancy's short and influential treatise on the 2011 nuclear disaster in Fukushima, "equivalence" qua the loss of the world to capital/capitalism is not simply the cause of catastrophe but one may say an anthropological catastrophe in itself that then inexorably leads to an environmental one. ${ }^{17}$ On the other hand, in Fœssel's work the loss of the world to technique, as a process that curtails our capacity to "make world", is the precondition for the end of the world becoming a universal concern, which, in turn, leads to further alienation from our world-making capacity by prioritizing life over the world as what needs to be protected and preserved. 
Where does this leave our critique of the pandemic imaginary as an instituted imaginary? It is at this point that it becomes pertinent to stress that what matters for an anthropology of human extinction is not simply to demonstrate the workings of the instituted imaginary, or the way in which "there is always a conservative ideal on the horizon of the ethics of the catastrophe, to the point that what must be done (or, conversely, what to refrain from) is evaluated by the yardstick of the possible disappearance of what surrounds us" but also to explore the way in which this instituted imaginary relates to the instituting capacity of the imaginary. ${ }^{18}$

\section{Between instituted and instituting}

It is a common mistake to think that autonomy and heteronomy are two opposed forms, forces or destinies of human societies tied together in an "epic struggle". ${ }^{19}$ Following this approach, it is easy to arrive at a binary like the one proposed by Shinichiro Asayama in his recent work on catastrophism and climate change. ${ }^{20}$ Asayama's schema opposes, on the one hand, what following Ulrich Beck he calls "emancipatory catastrophism", and, on the other hand, what he coins "apocalyptic catastrophism". ${ }^{21}$ The first "emancipatory catastrophism" (much like Dupuy's "enlightening catastrophism") involves the "imagination of a cosmopolitan horizon of global climate risk and [is] oriented to changing the mode of operation of modern society toward coping with 'cosmopolitan climate", ${ }^{22}$ Climate change, or the existential risk it poses to human societies, is thus seen as presenting us with "hidden" window of opportunity (perhaps humanity's last) for a process that Beck calls world-metamorphosis (Verwandlung), which involves "bringing climate change into our everyday practice to transform the meanings of human life". ${ }^{23}$ The second, "apocalyptic catastrophism", by contrast involves "the imagination of a dire future climate and the discourse to feed the idea of a 'techno-fix' as an alternative to curbing GHG emissions". ${ }^{24}$ For Asayama, the idea of the apocalyptic is here employed to convey "the apocalypse of a changed climate" and the "demise of politics", resulting from the abandonment of politics to technoscientific management, exemplified by geoengineering. ${ }^{25}$ Focused on transformation and catharsis, emancipatory catastrophism is thus posed at one end of the political spectrum, as a force promoting the opening up of "the space of deliberation", while apocalyptic catastrophism, focused as it is in the technoscientific reinvention of human mastery in extremis, is posed at the other end, as a force that fosters the urgent closure of this space as humanity's only hope for survival.

Rather than subsume the pandemic imaginary in this binary between "emancipatory catastrophism" and "apocalyptic catastrophism" - the one, via an act of "anthropological shock", opening up an opportunity for a "rebirth of modernity", the other "putting democracy on hold" through technologies of fear - we should take note of Castoriadis' approach of the tension between the instituting and the instituted faculty of the imaginary: "There will always be a distance between society as instituting and what is, at every moment, instituted". ${ }^{26}$ This distance is, however, "not something negative or deficient; it is one of the expressions 
of the creative nature of history", in the sense that it is "what prevents it from fixing itself once and for all into the 'finally found form' of social relations and of human activities, what makes a society always contain more than what it presents". 27

Taking a critical distance from perspectives that would reduce the pandemic imaginary to a dead weight of capitalist ideology, we thus need to assume a more dynamic approach. This distinctly punctuates Castoriadis' understanding of the imaginary:

Instituted society is not opposed to instituting society as a lifeless product to an activity which brought it into being; it represents the relative and transitory fixity/stability of the instituted forms-figures in and through which the radical imaginary can alone exist and make itself exist as social-historical. ${ }^{28}$

Rather than seeing it simply as a form or force of closure, we need to consider the instituted imaginary as the ground on which any society's autopoetic faculty is articulated and expressed through reflection, which in turn leads to a recognition of "the inertia of the already-instituted" and to "itself as the source of its own otherness". ${ }^{29}$ But how exactly are we to understand the way in which the tension between the instituting and the instituted imaginary plays out in social self-creation?

\section{Self-creation reconsidered}

An important contributor to the study of Castoriadis' philosophy of self-creation has proposed that the key to this puzzle is an aspect of the imaginary that is rarely associated with his analytic. Nicolas Poirier has identified this as being suspension. ${ }^{30}$ Tracing the affinities between Castoriadis and phenomenological approaches of the imaginary, Poirier explains that "putting into suspense the given determinations is what introduces play into situations whose configuration would appear to be definitive and which thus seem to exclude any other perspective from its field" ${ }^{31}$ Jeff Klooger has in turn proposed an approach of the relation between the instituting and the instituted aspect of the imaginary that, on the one hand, does less violence to Castoriadis' own theory, while, on the other hand, maintaining the "tension" at the heart of Poirier's interpretation. In Klooger's reading, the tension between the instituting and the instituted imaginary is foundational of social autopoiesis:

Self-creation inevitably involves both a striving for determination and against it, the establishment of boundaries as well as their rejection, the struggle to escape and transcend them. This dichotomy merely represent twin aspects of one and the same activity: self-creation as a perpetual mode of being. ${ }^{32}$

Accepting that the closure of an instituted society is never complete, and that partial closure, to the extent that it is historically in place, is part of a dynamic 
tension between heteronomy and autonomy, allows us to consider even the most heteronomic imaginary as not merely repressive, conserving, or reproductive. As part of an instituted imaginary, visions that pervade a wide range of popular and scientific representations of the next pandemic revolve around a projected inability of humankind to re-emerge in a world that is itself re-emerging as a result of humankind's "loss" of mastery. This may be said to be a heteronomous imaginary par excellence, to the extent that it sanctions ideas about what makes us human (mastery) as a transcendental nomos - an irreducible and unchangeable fact of human nature. Yet rather than reading this instituted imaginary through what Sneath, Holbraad, and Pedersen have identified as a "closet-functionalist" prism of instrumentality (Who or what does this imaginary serve? How is it rendered useful to this or that class, or political/economic system?), or as a surrogate for dialectics, Castoriadis' approach allows us to understand its anthropological import as an indispensable element of social self-creation. ${ }^{33}$ Following Klooger's reading of Castoriadis, and dispensing with the dialectical fantasy of overcoming "the distinction and tension between instituting and instituted society", we may thus be able to understand normative catastrophism (as embodied by the pandemic imaginary) not simply as a heteronomic matrix of significations but as always already part of autonomy as "a transformation of these two aspects of the social" that reaches out at the "creation of a new type of institution, one that it is not predicated on the repudiation and alienation of the source of self-creation". ${ }^{34}$

However, if the instituted imaginary is not to be seen as an obstacle to but as a component of social self-creation, and if we are to avoid a left-melancholic gesture that would reduce the "union and tension of instituting and of instituted society, of history made and history in the making" to a Hegelian dialectic, we should resist engaging in the usual practice of rummaging through the ruins of today for the germs of tomorrow's overcoming. ${ }^{35}$ Such move would have required us, at this stage, to conclude in a hopeful note, by providing some glimpses of what might one day transform the pandemic imaginary from an instituted to an instituting capacity. Thus, we would have proceeded by what we may qualify as a historicist parathesis; that is, by laying out of a series of examples (drawn from literature, film, art, etc.), where the supposed seeds of this political ontological transformation from the instituted to the instituting (or from heteronomy to autonomy) may be sensed, so that they might at some later point be "expanded" to take historical significance. This would be a fruitless exercise. For if what Arjun Appadurai has called an "ethics of possibility" is indeed part of the pandemic imaginary, this is not limited to such elements as it may "increase the horizons of hope, that expand the field of the imagination" so that anticipation may give way to aspiration. ${ }^{36}$

For the future to emerge out of its present heteronomic condition what is needed is far more than a reactivation of the "productive" capacity of the imagination or a restitution of the future "as an alterity of the present, rather than as a distant eventuality". ${ }^{37}$ Instead, what becomes necessary is much more difficult and much more demanding: a reimagining of the imaginary itself as a creative, rather than simply a productive, force. This entails an ability to envision an "emergent future" beyond the dichotomy of hope and despair, on the basis of a perspective 
of not only the human species and its societies but also of the nonhuman world as "essentially unfinished and in a state of process". ${ }^{38}$ A political ontological transformation can only occur once we abscond historicist quietism and accept that the autonomy-heteronomy tension is an integral and irreducible part of any futureoriented sociality - a process that needs "to be engaged with at the level of the imaginary and without trying to dispense with it". ${ }^{39}$

This has been the method followed by Human Extinction and the Pandemic Imaginary, a study aimed at illuminating the way in which humanity is configured and transformed when we consider it from the vantage point of its pandemicborne extinction. If anthropology, as Tim Ingold argues, is indeed "an inquiry into the conditions and possibilities of human life in the world" but also, to echo Christina Toren's recent critique of the idea of "human nature", the study of the "historical process of human autopoesis", the anthropological study of human extinction offers us a unique vantage point for examining the limits of these conditions and possibilities as instituted in the process of social self-creation. ${ }^{40}$ To such investigation, Castoriadis' political ontology offers a philosophical key. This is not only because it allows for an anthropological understanding of the imaginary beyond the binary straightjacket of "functionalism" and "constructivism" but also because it proposes an alluring alternative to mastery as the defining trait of being human and of human/nonhuman interaction. Neglected by anthropologists but pertinent in a time when the political and ontological aspects of human/ nonhuman relations are becoming central to anthropological investigation, the idea of society as self-creation offers vital tools for conceiving humankind's relation with the world as other than a project for mastery.

\section{Notes}

1 As Matthew Beaumont (2014) has noted, the actual quote, appearing in Jameson (1994), as the result of "probably misremembering some comments made by H. Bruce Franklin about J. G. Ballard". More recently, Jameson (2003: 76) has reflected: "We can now revise that and witness the attempt to imagine capitalism by way of imagining the end of the world".

2 Mark Fisher, Capitalist Realism (Winchester: Zero Books, 2009), 1. It is important that Fisher chose to formulate this principle by way of analyzing a quasi-pandemic film, Children of Men (2006).

3 Randall Colburn, "Apocalypse TV: Why Can't We Get Enough of World-Ending Telly?," The Guardian, January 8, 2018, accessed January 11, 2018 www.theguardian. com/tv-and-radio/2018/jan/08/apocalypse-tv-hard-sun-the-leftovers. Here The Stand refers to the American TV miniseries based on Stephen King's homonymous book where a weaponized influenza strain has been unleashed on Earth (Garris 1994). Under the Dome was another American TV series based on a Stephen King novel, depicting a community that wakes up surrounded by an impenetrable if invisible "dome", and the social consequences of this (Vaughan 2013-2015). The Leftovers was an American TV series based on a novel by Tom Perrotta, which depicted the social and psychological consequences of the sudden vanishing of $2 \%$ of the planet's human population (Lindelof and Perrotta 2014-17).

4 Michaël Fœssel, "La 'fin du monde': une métaphore pour le présent?," Esprit 388(10) (October 2012): 37, my translation. 
5 Lawrence Buell, The Environmental Imagination: Thoreau, Nature Writing, and the Formation of American Culture (Cambridge, MA: Harvard University Press, 1996); Günther Anders, L'Obsolescence de l'homme, translated by Christophe David (Paris: Éditions de l'Encyclopédie des nuisances, 2002), 15, my translation.

6 Fœssel, "La 'fin du monde': une métaphore pour le présent?," 36, emphasis in the original, my translation.

7 Fœssel, "La 'fin du monde': une métaphore pour le présent?," 37, my tranlsation. See also Walter Benjamin, "The Storyteller," In Theory of the Novel: A Historical Approach, ed. Michael McKeon, pp. 77-93 (Baltimore and London: John Hopkins University Press, 2000).

8 Jean-Pierre Dupuy, Pour un catastrophisme éclairé (Paris: Le Seuil, 2004); Timothy Morton, Dark Ecology: For a Logic of Future Coexistence (New York: Columbia University Press, 2016); Timothy Morton, Humankind: Solidarity with Nonhuman People (London: Verso, 2017).

9 Fœssel, "La 'fin du monde': une métaphore pour le présent?," 41, my translation.

10 Fœssel, "La 'fin du monde': une métaphore pour le présent?," 41, my translation.

11 M. Fœssel, Après la fin du monde, Critique de la raison apocalyptique (Paris: Seuil, 2012), 269-270, my translation.

12 Jean-Luc Nancy, After Fukushima: The Equivalence of Catastrophes (New York: Fordham University Press, 2014), 33.

13 Nancy, After Fukushima, 33.

14 Nancy, After Fukushima, 5.

15 Cyril Neyrat, "L'arche et le Titanic. Films-catastrophe et cinema du desastre," Critique 783-784 Penser la Catastrophe (aout-septembre 2012), 752, my translation.

16 Walter Benjamin, "Left-Wing Melancholy," In The Weimar Republic Sourcebook, eds. Anton Kaes, Martin Jay and Edward Dimendberg, pp. 304-306 (Berkeley, CA: The University of California Press, 1994 [1931]). See also: Ezno Traverso, Left-Wing Melancholia: Marxism, History, and Memory (New York: Columbia University Press, 2016). Wendy Brown (1999: 20) usefully summarizes the meaning of this term: "In Benjamin's enigmatic insistence on the political value of a dialectical historical grasp of 'the time of the Now,' left melancholy represents not only a refusal to come to terms with the particular character of the present, that is, a failure to understand history in terms other than 'empty time' or 'progress'." For a review of melancholia in Anthropocene and extinction studies and its critiques, see: Romain Noël, "Une science mélancolique," Critique 860-861 (2019): 136-150.

17 In this sense, Nancy is closer to Dupuy's metaphysics of urgency but also to the realism expressed in the recent work of Adriana Petryna and Paul Wolff Mitchell (2017: 347) on "catastrophic forms" where it is argued that, "Whatever cognitive constraints are invoked, the Anthropocene is not about fatalism, nihilism, or blind chance. It is about a continued ability to create knowledge to address the scope of existential threats. Along with the critical work of dismantling a global political economy erected on fossil fuels, it is also about taking whatever leap in the evolutionary dark is required to come to terms with the reality of abrupt change". However, Nancy's analysis retains an understanding that the global political economy is built primarily on social relations, such as alienated labor and domination, rather than simply on "fossil fuel".

18 Michaël Fœssel, Frédéric Worms, Simon Leplâtre and Marc-Olivier, "La catastrophe est-elle une politique?," Esprit 374(5) (May 2011): 60, my translation.

19 Laura Bieger, Ramon Saldivar and Johannes Voelz, "The Imaginary and Its Worlds: An Introduction," In The Imaginary and Its Worlds: American Studies after the Transnational Turn, eds. Laura Bieger, Ramon Saldivar and Johannes Voelz, pp. vii-xxviii (Lebanon, NH: Dartmouth College Press, 2013), xvii.

20 Shinichiro Asayama, “Catastrophism toward 'Opening Up' or 'Closing Down'? Going beyond the Apocalyptic Future and Geoengineering," Current Sociology 63(1) (2015): 89-93. 


\section{Conclusion}

21 Ulrich Beck, "Emancipatory Catastrophism: What Does It Mean to Climate Change and Risk Society?," Current Sociology 63(1) (2015): 75-88.

22 Shinichiro, "Catastrophism toward 'Opening Up' or 'Closing Down'?," 90-91.

23 Shinichiro, "Catastrophism toward 'Opening Up' or 'Closing Down'?," 92. For an extensive discussion of this thesis, see: Ulrich Beck, The Metamorphosis of the World: How Climate Change Is Transforming Our Concept of the World (London: Polity, 2016).

24 Shinichiro, "Catastrophism toward 'Opening Up' or 'Closing Down'?," 90.

25 Shinichiro, "Catastrophism toward 'Opening Up' or 'Closing Down'?," 92.

26 Shinichiro, "Catastrophism toward 'Opening Up' or 'Closing Down'?," 92; Cornelius Castoriadis, The Imaginary Institution of Society (Cambridge, MA: MIT Press, 1987),

27 Castoriadis, The Imaginary Institution of Society, 73.

28 Castoriadis, The Imaginary Institution of Society, 227.

29 Castoriadis, The Imaginary Institution of Society, 132-133.

30 For an anthropological examination of suspension as integral to scientific thinking, see: Matei Candea, "Suspending Belief: Epoché in Animal Behavior Science," American Anthropologist 115(3) (2013): 423-436.

31 Nicolas Poirier, "Castoriadis et l'imaginaire radical: Une confrontation avec la phénoménologie," Bulletin d'analyse phénoménologique 13(2) (Actes 10) (2017): 465, my translation. For further discussion on Castoriadis and phenomenology, see: Suzi Adams, Castoriadis's Ontology: Being and Creation (New York: Fordham University Press, 2011).

32 Jeff Klooger, Castoriadis: Psyche, Society, Autonomy (Amsterdam: Brill Press, 2009). 29.

33 David Sneath, Martin Holbraad and Morten Axel Pedersen, "Technologies of the Imagination: An Introduction," Ethnos, 74(1) (2006): 5-30.

34 Klooger, Castoriadis: Psyche, Society, Autonomy, 32.

35 Castoriadis, The Imaginary Institution of Society, 184. For an example of this, as regards climate change, see: Nicholas Beuret and Gareth Brown, "The Walking Dead: The Anthropocene as a Ruined Earth," Science as Culture 26(3) (2017): 330-354.

36 Arjun Appadurai, The Future as Cultural Fact: Essays on the Global Condition (New York: Verso, 2013), 295.

37 Appadurai, The Future as Cultural Fact: Essays on the Global Condition; SarahPink, Yoko Akama and Annie Fergusson, "Researching Future as an Alterity of the Present," In Anthropologies and Futures: Researching Emerging and Uncertain World, eds. Juan Francisco Salazar, et al., pp. 133-150 (London and New York: Bloomsbury, 2017), 133.

38 Ruth Levitas, "Educated Hope: Ernst Bloch on Abstract and Concrete Utopia," Utopian Studies 1(2) (1990), 18, 17.

39 Kathleen Lennon, Imagination and the Imaginary (London and New York: Routledge, 2015), 88.

40 Tim Ingold, “Anthropology Contra Ethnography," HAU: Journal of Ethnographic Theory 7(1) (2017): 22; Christina Toren, "Human Ontogenies as Historical Process: An Anthropological Perspective," In Why We Disagree about Human Nature, eds. Elizabeth Hannon and Tim Lewens, pp. 170-185 (Oxford: Oxford University Press, 2018), 182. 


\section{Bibliography}

Anonymous. "The Biohazard Symbol.” https://cws.auburn.edu/shared/content/files/1621/ biohazard-history.pdf

Anonymous. "Chita Teenagers Not Suffering from Bird Flu." April 28, 2006 www. besttopnews.com/news/news/28-04-2006/22133-0/

Anonymous. "Chinese Embassy in Russia: The Death of the Woman Has Not Been Diagnosed with SARS." Flutrackers, April 15, 2009 www.flutrackers.com/forum/showthread. php?t=99392\&page $=2$

Anonymous. "Chinese Woman Dies from Suspected SARS on Moscow-Bound Train." Novosti, April 15, 2009 http://en.ria.ru/world/20090415/121145477.html

Anonymous. "Mediki vuiyasnyat, popala li v Rossiyu atipochnaya pnevmoniya." BBC Russia, April 16, 2009 http://news.bbc.co.uk/hi/russian/russia/newsid_8001000/8001412.stm

Anonymous. "Suspected SARS Death on Russian Train Confirmed as Pneumonia." Novosti, April 16, 2009 http://en.ria.ru/russia/20090416/121157796.html

Anonymous. "Contagion Production Notes: Hollywood: Warner Bros: Pictures, 2011.” www. visualhollywood.com/movies_2011/contagion/notes.pdf

Anonymous. "Germ Warfare.” Post Magazine, December 1, 2013.

Anonymous."1992: Sarajevo's Zoo in Wartime.” CNN, May 22, 2014 http://edition.cnn. com/videos/world/2014/05/22/pkg-1992-amanpour-bosnia-sarajevo-zoo.cnn

Anonymous. "The New Plague: We're One Mutation Away from the End of the World as We Know It” (Cover). New Scientist, May 9-15, 2015.

Ackerknecht, Erwin H. "Anticontagionism between 1821 and 1867, the Fielding H. Garrison Lecture.” International Journal of Epidemiology 38 (2009): 7-21.

Adams, Suzi. "Castoriadis and Autopoesis.” Thesis Eleven 88(1) (2007): 76-91.

Adams, Suzi. Castoriadis's Ontology: Being and Creation. New York: Fordham University Press, 2011.

Adams, Suzi. “Autonomy.” In Cornelius Castoriadis: Key Concepts, edited by Suzi Adams, 1-12. London and New York: Bloomsbury, 2014.

Adams, Suzi (ed.). Ricoeur and Castoriadis in Discussion: On Human Creation, Historical Novelty and the Social Imaginary. Lanham: Rowman and Littlefield, 2017.

Adorno, Theodor W. Über Walter Benjamin: Aufsätze, Artikel, Briefe. Frankfurt: Suhrkamp, 1990.

Afeissa, Hicham-Stéphane. La fin du monde et de l'humanité. Essai de généalogie du discours écologique. Paris: Presses Universitaires de France, 2014.

Agamben, Giorgio. The Open: Man and Animal, translated by Kevin Attell. Stanford, CA: Stanford University Press, 2004.

Agamben, Giorgio. The Time That Remains: A Commentary on the Letter to the Romans, translated by Patricia Dailey. Stanford, CA: Stanford University Press, 2005. 
Agamben, Giorgio. The Use of Bodies, translated by Adam Kotsko. Stanford, CA: Stanford University Press, 2016.

Agamben, Giorgio. The Fire and the Tale, translated by Lorenzo Chiesa. Stanford, CA: Stanford University Press, 2017.

Agamben, Giorgio. The Mystery of Evil: Benedict XVI and the End of Days, translated by Adam Kotsko. Stanford, CA: Stanford University Press, 2017.

Agamben, Giorgio. Taste, translated by Francis Cooper. London, New York and Calcutta: Seagull Books, 2017.

Ahuja, Neel. Bioisecurities: Disease Interventions, Empire, and the Government of Species. Durham, NC: Duke University Press, 2016.

Ali, S. Harris and Roger Keil (eds.). Networked Disease: Emerging Infections in the Global City. Oxford: Blackwell Publishers, 2008.

Anders, Günther. Die Antiquiertheit des Menschen Bd. I: Über die Seele im Zeitalter der zweiten industriellen Revolution. Munich: C.H. Beck, 2002.

Anders, Günther. L'Obsolescence de l'homme, Sur l'âme à l'époque de la deuxième révolution industrielle (1956), translated by Christophe David. Paris: Éditions de 1'Encyclopédie des Nuisances/ Éditions Ivrea, 2002.

Anders, Günther. Le temps de la fin. Paris: L'Herne, 2007.

Anders, Günther. Hiroshima est partout. Paris: Seuil, 2008.

Anderson, John. "Images Show What Could Happen If Britain Was Hit by the Last of Us Virus." ShopTo, June 13, 2013 www.shopto.net/news/43167/Images-show-what-couldhappen-if-Britian-got-The-Last-of-Us-virus

Anderson, Warwick. "The Possession of Kuru: Medical Science and Biocolonial Exchange." Comparative Studies in Society and History 42(4) (2000): 713-744.

Anderson, Warwick. Colonial Pathologies: American Tropical Medicine, Race, and Hygiene in the Philippines. Durham, NC: Duke University Press, 2006.

Anshelm, Jonas and Martin Hultman. Discourses of Global Climate Change: Apocalyptic Framing and Political Antagonisms. London and New York: Routledge, 2015.

Appadurai, Arjun. The Future as Cultural Fact: Essays on the Global Condition. London: Verso, 2013.

Arnason, Johann P. "Institution.” In Cornelius Castoriadis Key Concepts, edited by Suzi Adams, 101-106. London and New York: Bloomsbury, 2014.

Arnason, Johann P. "Castoriadis and Ricoeur on Meaning and History: Contrasts and Convergences." In Ricoeur and Castoriadis in Discussion: On Human Creation, Historical Novelty and the Social Imaginary, edited by Suzi Adams, 49-75. Lanham: Rowman and Littlefield, 2017.

Arnold, David. "The Place of 'the Tropics' in Western Medical Ideas since 1750." Tropical Medicine and International Health 2(4) (April 1997): 303-313.

Arnold, David. The Tropics and the Traveling Gaze: India, Landscape, and Science, 18001856. Washington, DC: The University of Washington Press, 2006.

Artaud, Antonin. The Theater and Its Double. New York: Grove Press, 1958.

Asayama, Shinichiro. 'Catastrophism toward 'Opening Up' or 'Closing Down'? Going beyond the Apocalyptic Future and Geoengineering." Current Sociology 63(1) (2015): 89-93.

Atkinson, John E. "Turning Crises into Drama: The Management of Epidemics in Classical Antiquity." Acta Classica 44 (2001): 35-52.

Bachvarona, Mary R. and Dorota Dutsch. "Mourning a City 'Empty of Me': Stereotypes of Anatolian Communal Lament in Aeschylus' Persians." In The Fall of Cities in the Mediterranean: Commemoration in Literature, Folk-Song, and Liturgy, edited by 
Mary R. Bachvarona and Dorota Dutsch, 79-105. Cambridge: Cambridge University Press, 2017.

Bacot, A., George F. Petrie and Captain R. E. Todd. "The Fleas Found on Rats and Other Rodents, Living in Association with Man, and Trapped in the Towns, Villages and Nile Boats of Upper Egypt." Journal of Hygiene 14(4) (December 1914): 498-508.

Barker, Sheila. "Poussin, Plague, and Early Modern Medicine." The Art Bulletin 86(4) (December 2004): 659-689.

Barnes, David S. 'Cargo, 'Infection,' and the Logic of Quarantine in the Nineteenth Century." Bulletin of the History of Medicine 88(1) (2014): 75-101.

Barnes, David S. “'Until Cleansed and Purified': Landscapes of Health in the Interpermeable World." Change Over Time 6(2) (Fall 2016): 138-152.

Barthes, Roland. Camera Lucida, translated by Peter Howard. New York: Hill and Wang, 1981. Bashford, Alison. "Is White Australia Possible? Race, Colonialism and Tropical Medicine." Ethnic and Racial Studies 23 (2000): 248-271.

Bashford, Alison and C. Hooker (eds.). Contagion: Historical and Cultural Studies. London and New York: Routledge, 2014.

Baudrillard, Jean. "The Anorexic Ruins." In Looking Back at the End of the World, edited by Dietmar Kamer and Christoph Wulf, translated by David Antal, 29-45. New York: Semiotext(e), 1989.

Bauman, Zygmunt. “A Natural History of Evil.” S.I.M.O.N., March 22, 2012 http://simon. vwi.ac.at/index.php/swl-reader/21-a-natural-history-of-evil

Beall, E. F. "Hesiod's Prometheus and Development in Myth." Journal of the History of Ideas 52(3) (July-September 1991): 355-371.

Beaumont, Matthew. "Imagining the End Times: Ideology, the Contemporary Disaster Movie, Contagion." In Žižek and Media Studies: A Reader, edited by Matthew Flisfeder and Louis-Paul Willis, 79-89. Basingstone: Palgrave Macmillan, 2014.

Beck, Ulrich. "Emancipatory Catastrophism: What Does It Mean to Climate Change and Risk Society?" Current Sociology 63(1) (2015): 75-88.

Beck, Ulrich. The Metamorphosis of the World: How Climate Change Is Transforming Our Concept of the World. Cambridge: Polity Press, 2016.

Ben Ari, Tamara, Simon Neerinckx, Kenneth L. Gage, Katharina Kreppel, Anne Laudisoit, Herwig Leirs and Nils Chr. Stenseth. "Plague and Climate: Scales Matter". PLoS Pathogens 7(9) (2011): e1002160. https://doi.org/10.1371/journal.ppat. 1002160.

Benitez, Marry Ann. "Scientists Revisit Outbreak Hospitals." South China Morning Post, March 2, 2005 www.scmp.com/article/490922/scientists-revisit-outbreak-hospitals

Benjamin, Walter. Reflections: Essays, Aphorism, Autobiographical Writings, edited by Peter Demetz. New York: Schocken, 1986.

Benjamin, Walter. "The Work of Art in the Age of Mechanical Reproduction", translated by Harry Zohn. In Illuminations, 217-251. New York: Schocken, 1986 [1936].

Benjamin, Walter. "Left-Wing Melancholy." In The Weimar Republic Sourcebook, edited by Anton Kaes, Martin Jay and Edward Dimendberg, 304-306. Berkeley, CA: The University of California Press, 1994 [1931].

Benjamin, Walter. "The Storyteller." In Theory of the Novel: A Historical Approach, edited by Michael McKeon, 77-93. Baltimore and London: John Hopkins University Press, 2000 [1936].

Berdet, Marc. "Chiffonnier contre flâneur: Construction et position de la Passagenarbeit de Walter Benjamin." Archives de Philosophie 75(3) (2012): 425-447.

Berdet, Marc. "Eight Thesis on Phantasmagoria." Anthropology \& Materialism 1 (2013) https://am.revues.org/225\#tocto1n3 
Berger, James. After the End: Representations of Post-Apocalypse. Minneapolis: University of Minnesota Press, 1999.

Berger, Jonah. Contagious: Why Things Catch On. New York and London: Simon \& Schuster, 2013.

Beuret, Nicholas and Gareth Brown. "The Walking Dead: The Anthropocene as a Ruined Earth." Science as Culture 26(3) (2017): 330-354.

Bibel, David J. and T. E. Chen. "Diagnosis of Plague: An Analysis of the Yersin-Kitasato Controversy.” Bacteriological Reviews 40(3) (September 1976): 633-651.

Bieger, Laura, Ramon Saldivar and Johannes Voelz. "The Imaginary and Its Worlds: An Introduction." In The Imaginary and Its Worlds: American Studies after the Transnational Turn, edited by Laura Bieger, Ramon Saldivar and Johannes Voelz, vii-xxviii. Lebanon, NH: Dartmouth College Press, 2013.

Biehl, João. Vita: Life in a Zone of Social Abandonment. Berkeley, CA: The University of California Press, 2005.

Bihari Mukharji, Projit. "Cat and Mouse: Animal Technologies, Trans-Imperial Networks and Public Health from Below, British India, c. 1907-1918." Social History of Medicine https://doi.org/10.1093/shm/hkx024

Bloom, Barry R. “Lessons from SARS.” Science 300(5620) (May 2, 2003): 701.

Bloomfield, Samuel Thomas (trans.). The History of Thucydides, Vol. 1. London: Longman, 1829.

Boeckl, Christine M. Images of Plague and Pestilence: Iconography and Iconology. Kirksville, MO: Truman State University Press, 2000.

Boluk, Stephanie and Wylie Lenz. "Infection, Media, and Capitalism: From Early Modern Plagues to Postmodern Zombies.” Journal for Early Modern Cultural Studies 10(2) (Fall/Winter 2010): 126-147.

Boluk, Stephanie and Wylie Lenz (eds.). Generation Zombie: Essays on the Living Dead in Modern Culture. Jefferson: McFarland \& Co, 2011.

Bond, Henry. Lacan at the Scene. Cambridge, MA: The MIT Press, 2009.

Bostrom, Nick. "Existential Risks: Analyzing Human Extinction Scenarios and Related Hazards." Journal of Evolution and Technology 9 (March 2002) www.jetpress.org/ volume9/risks.html

Bostrom, Nick. "Existential Risk Prevention as Global Priority." Global Policy 4(1) (February 2013): 15-31.

Boyle, T. C. After the Plague. New York: Viking Press, 2011.

Braden, Christopher R., Scott F. Dowell, Daniel B. Jernigan and James M. Hughes. "Progress in Global Surveillance and Response Capacity 10 Years after Severe Acute Respiratory Syndrome." Emerging Infectious Diseases 16(6) (2013): 864-869.

Braidotti, Rosi. "Posthuman Critical Theory." In Critical Posthumanism and Planetary Futures, edited by D. Banerji and M. R. Paranjape, 13-31. Singapore: Springer 2016.

Branswell, Helen. “'Superspreaders' Could Turn New Coronavirus into SARS-Like Event: Experts." The Canadian Press, March 25, 2013 www.ctvnews.ca/health/superspreaderscould-turn-new-coronavirus-into-sars-like-event-experts-1.1210070

Brantlinger, Patrick. Dark Vanishings: Discourse on the Extinction of Primitive Races, 1800-1930. Ithaca, NY: Cornell University Press, 2003.

Brassier, Ray. Nihil Unbound: Enlightenment and Extinction. New York: Palgrave Macmillan, 2007.

Breban, Romulus, Raffaele Vardavas and Sally Blower. "Theory versus Data: How to Calculate $\mathrm{R}_{0}$ ?" PLoS One (March 2007) http://dx.doi.org/10.1371/journal.pone.0000282 
Briggs, Charles. "Pressing Plagues: On the Mediated Communicability of Virtual Epidemics." In Plagues and Epidemics: Infected Spaces Past and Present, edited by D. A. Herring and Alan C. Swedlund, 39-60. Oxford: Berg, 2010.

Briggs, Charles and M. Nichter. "Biocommunicability and the Biopolitics of Pandemic Threats." Medical Anthropology 28(3) (2009): 189-198.

Brown, Hannah and Ann H. Kelly. "Material Proximities and Hotspots: Toward an Anthropology of Viral Hemorrhagic Fevers." Medical Anthropology Quarterly 28(2) (2014): 280-303.

Brown, Wendy. "Resisting Left-Wing Melancholy." Boundary2 26(3) (1999): 19-27.

Brown, Wendy. Walled States, Waning Sovereignty. Cambridge, MA: Zone Books, 2010.

Bruzzone, Rachel. "Polemos, Pathemata, and Plague: Thucydides' Narrative and the Tradition of Upheaval." Greek, Roman, and Byzantine Studies 57(4) (2017): 882-909.

Buck-Morss, Susan. “Aesthetics and Anaesthetics: Walter Benjamin's Artwork Essay Reconsidered." October 62 (Autumn 1992): 3-41.

Buck-Morss, Susan. "The City as Dreamworld and Catastrophe." October 73 (Summer 1995): 3-26.

Buell, Lawrence. The Environmental Imagination: Thoreau, Nature Writing, and the Formation of American Culture. Cambridge, MA: Harvard University Press, 1996.

Bull, Malcolm. "On Making Ends Meet." In Apocalypse Theory and the Ends of the World, edited by Malcolm Bull, 1-17. Oxford: Oxford University Press, 1995.

Buxton, Richard G. A. "Blindness and Limits: Sophokles and the Logic of Myth." Journal of Hellenic Studies 100 Centenary Issue (1980): 22-37.

Cacciari, Massimo, Alessandro Carrera and Massimo Verdicchio. "Empire and Katechon: A Question of Political Theology (from Paul, 2 Thessalonians 2)." In Europe and Empire, edited by Massimo Cacciari, Alessandro Carrera and Massimo Verdicchio, 145-157. New York: Fordham University Press, 2016.

Caduff, Carlo. "Pandemic Prophecy, or How to Have Faith in Reason." Current Anthropology 55(3) (June 2014): 296-315.

Caduff, Carlo. "Sick Weather Ahead: On Data-Mining, Crowd-Sourcing, and White Noise." The Cambridge Journal of Anthropology 32(1) (June 2014): 32-46.

Caduff, Carlo. The Pandemic Perhaps: Dramatic Events in a Public Culture of Danger. Berkeley, CA: The University of California Press, 2015.

Caillois, Roger. "Mimicry and Legendary Psychasthenia." 1935 http://generation-online. org/p/fpcaillois.htm

Calder Williams, Evan. Combined and Uneven Apocalypse. Hants: Zero Books, 2011.

Candea, Matei. "Suspending Belief: Epoché in Animal Behavior Science." American Anthropologist 115(3) (2013): 423-436.

Canosa, R. Tempo di peste: magistrate e untori nel 1630 a Milano. Rome: Sepere, 2000.

Caroll, Michael P. "Lévi-Strauss, Freud, and the Trickster: A New Perspective Upon an Old Problem." American Ethnologist 8(2) (1981): 301-313.

Castel, Pierre-Henri. Le Mal qui vient. Essai hâtif sur la fin des temps. Paris: Éditions du Cerf, 2018.

Castoriadis, Cornelius. The Imaginary Institution of Society, translated by Kathleen Blamey. Cambridge, MA: The MIT Press, 1987 [1975].

Castoriadis, Cornelius. Fait et à faire; Les carrefours du labyrinthe, Vol. 5. Paris: Seuil, 1997.

Castoriadis, Cornelius. "The Imaginary: Creation in the Social-Historical Domain." In The Castoriadis Reader, edited by David Ames Curtis. Oxford: Blackwell, 1997 [1989]. 
Castoriadis, Cornelius. "L'anthropogonie chez Eschyle et chez Sophocle." In La Grèce pour penser l'avenir, edited by Marc Augé, Cornélius Castoriadis, Maria Daraki, Philippe Descola, Claude Mossé, André Motte, Gilbert Romeyer-Dherby and Marie-Henriette Quet, 151-172. Paris: L'Harmattan, 2000.

Castoriadis, Cornelius. Figures of the Thinkable, translated by Helen Arnold. Stanford, CA: Stanford University Press, 2007 [1999].

Castoriadis, Cornelius. "Life and Creation: Cornelius Castoriadis in Dialogue with Francisco Varela", translated by John V. Garner. In Postscript on Insignificance: Dialogues with Cornelius Castoriadis, edited by Gabriel Rockhill, 58-73. New York and London: Continuum, 2011.

Castoriadis, Cornelius. "E $\mathrm{\varepsilon v \theta \varepsilon \rho í \alpha} \mathrm{\eta ்} \mathrm{H \sigma v \chi í \alpha} \mathrm{[fragment} \mathrm{from} \mathrm{interview} \mathrm{to} \mathrm{Stella} \mathrm{Mane,}$ 1990]."YouTube, December 21, 2012 www.youtube.com/watch?v=N_OB6oFAePE

Centres for Disease Control and Prevention. "Remembering SARS: A Deadly Puzzle and the Efforts to Solve It." Centres for Disease Control and Prevention, April 26, 2013 www.cdc.gov/about/history/sars/feature.htm

Chakrabarti, Pratik. Bacteriology in British India: Laboratory Medicine and the Tropics. Rochester, NY: University of Rochester Press, 2012.

Chamayou, Grégoire. Les chasses à l'homme: Histoire et philosophie du pouvoir cynegetique. Paris: La Fabrique, 2010.

Chan, Margaret. "The Lessons of SARS, 10 Years On." South China Morning Post, February 20, 2013 www.scmp.com/comment/insight-opinion/article/1154055/lessonssars-10-years

Chan, Paul K. S. and Martin C. W. Chan. "Tracing the SARS-Coronavirus." Journal of Thoracic Disease 5(S2) (2013): S118-S121.

Chang, Jiat-Hwee. A Genealogy of Tropical Architecture: Colonial Networks, Nature and Technoscience. London and New York: Routledge, 2014.

Chernela, Janet. “A Species Apart: Ideology, Science and the End of Life." The Anthropology of Extinction: Essays on Culture and Species Death, edited by Genese Marie Sodikoff, 18-38. Bloomington and Indianapolis: Indiana University Press, 2012.

Chinese Medical Association. "Consensus for the Management of Severe Acute Respiratory Syndrome." The Chinese Medical Journal 116(11) (November 2003): 1603-1635.

Christensen, Allan Conrad. Nineteenth-Century Narratives of Contagion: 'Our Feverish Contact'. London and New York: Routledge, 2005.

Christie, Deborah and Sarah Juliet Lauro. Better Off Dead: The Evolution of the Zombie as Post-Human. New York: Fordham University Press, 2011.

Clasen, Mathias. "Vampire Apocalypse: A Biocultural Critique of Richard Matheson's I am Legend." Philosophy and Literature 34(2) (October 2010): 313-328.

Clémot, Hugo. "Une lecture des films d'horreur épidémique." Tracés. Revue de sciences humaines 11 (2011): 167-184.

Colburn, Randall. “Apocalypse TV: Why Can't We Get Enough of World-Ending Telly?” The Guardian, January 8, 2018 www.theguardian.com/tv-and-radio/2018/jan/08/apocalypsetv-hard-sun-the-leftovers

Collier, Stephen J. and Andew Lakoff. "Vital Systems Security: Reflexive Biopolitics and the Government of Emergency." Theory, Culture and Society 32(2) (2015): 19-51.

Collins, Harry and Trevor Pinch. The Golem: What You Should Know about Science. Cambridge: Cambridge University Press, 2012.

Connon, Linda H. Climate Change and Anthropos: Planet, People and Places. London and New York: Routledge, 2010. 
Cooser, Amanda. "Google Maps Hack Turns any Street View into an Urban Jungle." CNET, March 19, 2014 www.cnet.com/news/google-maps-hack-turns-any-street-view-into-anurban-jungle/

Coste, Florent, Adrien Minard and Aurélien Robert. "Contagions. Histoires de la précarité humaine." Tracés. Revue de sciences humaines 21 (2011): 7-20.

Crapanzano, Vincent. Imaginative Horizons: An Essay in Literary-Philosophical Anthropology. Chicago: The University of Chicago Press, 2004.

Cronon, William. "The Trouble with Wilderness: Or, Getting Back to the Wrong Nature." Environmental History 1(1) (January 1996): 7-28.

Cunningham, Andrew. "Transforming Plague: The Laboratory and the Identity of Infectious Disease." In The Laboratory Revolution in Medicine, edited by Andrew Cunningham and Perry Williams, 209-244. Cambridge: Cambridge University Press, 1992.

Cunningham, David and Alexandra Warwick. "The Ambassadors of Nil: Notes on the Zombie Apocalypse." In Apocalyptic Discourse in Contemporary Culture: Post-Millenial Perspectives of the End of the World, edited by Monica Germana and Aris Mousoutzanis. London and New York: Routledge, 2014.

Danowski Déborah and Eduardo Viveiros de Castro. The Ends of the World, translated by Rodrigo Nunes. Cambridge: Polity Press.

Darwin, Charles. On the Origins of Species by Means of Natural Selection, or, the Preservation of Favoured Races in the Struggle for Life. Madison Park: Pacific Publishing Studio, 2010 [1859].

Davey, Thomas Herbert. and William Paterson Hay Lightbody. The Control of Disease in the Tropics: A Handbook for Medical Practitioners, Second edition. London: H.K. Lewis \& Co, 1961.

Davis, Mark. “'Is It Going to Be Real?' Narrative and Media on a Pandemic." Forum: Qualitative Social Research 18(1) (January 2017) www.qualitative-research.net/index. $\mathrm{php} /$ fqs/article/view/2768/4067

Dawsey, Jason. "After Hiroshima: Günther Anders and the History of Anti-Nuclear Critique." In Understanding the Imaginary War: Culture, Thought and Nuclear Conflict, 1945-90, edited by Matthew Grant and Benjamin Ziemann. Manchester: Manchester University Press, 2016.

Deleuze, Gilles and Felix Guattari. Capitalism and Schizophrenia II: A Thousand Plateaux. New York and London: Continuum, 2004.

Dellamora, Richard. "Introduction." In Postmodern Apocalypse: Theory and Cultural Practice at the End, edited by Richard Dellamora. Philadelphia: University of Pennsylvania Press, 1995.

de Martino, Ernesto. La fin du monde: Essai sur les apocalypses culturelles. Paris: Editions de l'Ecole des Hautes Etudes en Sciences Sociales, 2016.

Derrida, Jacques and John P. Leavey, Jr. "Of an Apocalyptic Tone Recently Adopted in Philosophy." Semeia 23 (1982): 3-37.

Descola, Philippe. La Fabrique des images: Visions du monde et formes de la representation. Paris: Musée du quai Branly and Somogy, 2010.

Descola, Philippe. Beyond Nature and Culture, translated by Janet Lloyd. Chicago: The University of Chicago Press, 2013.

Diamond, Jared. Collapse: How Societies Choose to Fail or Succeed. New York: Viking Press, 2005.

Dodds, Eric R. The Greeks and the Irrational. Berkeley, CA: The University of California Press, 1951. 


\section{Bibliography}

Newman Dorland, William Alexander. The American Illustrated Medical Dictionary. Philadelphia and London: W.B. Saunders \& Company, 1900.

Dosse, François. "The Social Imaginary as Engine of History in Ricoeur and Castoriadis", translated by Natalie J. Doyle. In Ricoeur and Castoriadis in Discussion. On Human Creation, Historical Novelty and the Social Imaginary, edited by Suzi Adams, pp. 139-169. Lanham: Rowman and Littlefield, 2017.

Draper Lowe, London and Faye I. Hummel. "Disaster Readiness for Nurses in the Workplace: Preparing for the Zombie Apocalypse." Workplace Health and Safety 62(5) (2014): 207-213.

Drezner, Daniel W. "Metaphor of the Living Dead: Or, the Effect of the Zombie Apocalypse on Public Policy Discourse." Social Research: An International Quarterly 81(4) (Winter 2014): 825-849.

Drucker, Johanna. Graphesis: Visual Forms of Knowledge Production. Cambridge, MA: Harvard University Press, 2014.

Duncan, James. S. In the Shadows of the Tropics: Climate, Race and Biopower in Nineteenth Century Ceylon. London and New York: Routledge, 2007.

Dupuy, Jean-Pierre. Pour un catastrophisme éclairé. Quand l'impossible est certain. Paris: Seuil, 2004.

Dupuy, Jean-Pierre. "Enlightened Doomsaying and the Concern for the Future." Ritsumeikan Studies in Language and Culture 24(4) (March 2013): 7-13.

Dupuy, Jean-Pierre. The Mark of the Sacred, translated by B. Debevoise. Stanford, CA: Stanford University Press, 2013.

Dupuy, Jean-Pierre. La guerre qui ne peur pas avoir lieu. Essai de métaphysique nucléaire. Paris: Desclée de Brouwer, 2018.

Echenberg, Myron J. Plague Ports: The Global Urban Impact of Bubonic Plague, 18941901. New York: New York University Press, 2007.

Edmond, Rod. "Returning Fears: Tropical Disease and the Metropolis." In Tropical Visions in an Age of Empire, edited by Felix Driver and Luciana Martins, 175-194. Chicago: The University of Chicago Press, 2005.

Ehgartner, Ulrike, Patrick Gould and Marc Hudson. "On the Obsolescence of Human Beings in Sustainable Development." Global Discourse, an Interdisciplinary Journal of Current Affairs and Applied Contemporary Thought 7(1) After Sustainability - What? (July 2017): 66-83.

Elton, Charles. Animal Ecology. London: Sidgwick \& Jackson, 1927.

Engelmann, Lukas. "Fumigating the Hygienic Model City: Bubonic Plague and the Sulfurozador in Early-Twentieth-Century Buenos Aires." Medical History 62(3): 360.

Enright, Kelly. The Maximum of Wilderness: The Jungle in the American Imagination. Charlottesville: Virginia University Press, 2012.

Esposito, Roberto. Immunitas: The Protection and Negation of Life. Cambridge: Polity Press, 2011.

Evans, Nicholas H. 2018. "Blaming the Rat? Accounting for Plague in Colonial Indian Medicine." Medicine, Anthropology, Theory 5(3): 15-42.

Falco, Miriam. "New SARS-like Virus Poses Medical Mystery." CNN, September, 242012 http://thechart.blogs.cnn.com/2012/09/24/new-sars-like-virus-poses-medical-mystery/

Faubion, James D. "Untitled" [Comment to C. Caduff "Pandemic Prophecy, or How to Have Faith in Reason"]. Current Anthropology 55(3) (2014): 306-307.

Fava, Sergio. Environmental Apocalypse in Science and Art: Designing Nightmares. London and New York: Routledge, 2013.

Fischer, Michael M. J. Anthropological Futures. Durham, NC: Duke University Press, 2009.

Fisher, Mark. Capitalist Realism. Winchester: Zero Books, 2009. 
Flemming, Marc. “'Super-Spreader' Survivor Has Become Scapegoat.” The Times, April 23, 2003 www.thetimes.co.uk/tto/news/world/article1987274.ece

Fœssel, Michaël. Après la fin du monde, Critique de la raison apocalyptique. Paris: Seuil, 2012.

Fœssel, Michaël. "La "fin du monde”: une métaphore pour le présent?" Esprit 388(10) (October 2012): 31-41.

Fœssel, Michaël, Frédéric Worms, Simon Leplâtre and Marc-Olivier. "La catastrophe estelle une politique?" Esprit 374(5) (May 2011): 54-70.

Forth, Scott. “A Biophysicist Fact-Checks World War Z's Swarming, Sniffing, Tireless Zombies." Vulture, June 25, 2013 http:/www.vulture.com/2013/06/biophysicist-assessesworld-war-z.html

Foucault, Michel. Abnormal: Lectures at the Collège de France, 1974-1975, translated by Graham Burchell. London: Picador, 2004.

Foucault, Michel. The Courage of the Truth (The Government of Self and Others II): Lectures at the Collège de France, 1983-1984, translated by Graham Burchell. Basingstoke: Palgrave Macmillan, 2011.

Fowkes Tobin, Beth. Colonizing Nature: The Tropics in British Arts and Letters, 17601820. Philadelphia: University of Pennsylvania, 2004.

Fraustino, Julia Daisy and Liang Ma. "CDC'S Use of Social Media and Humor in a Risk Campaign: 'Preparedness 101: Zombie Apocalypse'." Journal of Applied Communication Research 43(2) (2015): 222-242.

Fressard, Olivier. "Castoriadis, le symbolique et l'imaginaire." In L'imaginaire selon Castoriadis: Thèmes et enjeux, edited by S. Klimis and L. Van Eynde, 119-150. Brussels: Facultés Universitaires Saint-Louis, 2006.

Fuggle, Sophie. "To Have Done with the End-Times: Turning the Apocalypse into a Nonevent." In Apocalyptic Discourse in Contemporary Culture: Post-Millennial Perspectives on the End of the World, edited by M. Germana and A. Mousoutzanis. London and New York: Routledge, 2014.

Gallagher, James. "Ebola 'Super-Spreaders' Cause Most Cases.” BBC News, February 14, 2017www.bbc.com/news/health-38955871

Gammeltoft, Tine M. "Toward an Anthropology of the Imaginary: Specters of Disability in Vietnam." Ethnos 42(2) (June 2014): 153-174.

Gaonkar, Dilip Parameshwar. "Toward New Imaginaries: An Introduction.” Public Culture 14(1) (2002): 1-19.

Garcia, Angela. The Pastoral Clinic: Addiction and Dispossession along the Rio Grande. Berkeley, CA: The University of California Press, 2010.

Garrett, Laurie. The Coming Plague: Newly Emerging Diseases in a World Out of Balance. New York: Farrar, Straus and Giroux, 1994.

Gear, Jennifer. "Performing Plague: Antonio Zanchi and the Dynamics of Spectatorship at the Scuola Grande di San Rocco in Venice.” Renaissance Studies (2017)doi:10.1111/ rest. 12360

Gerlach, Neil and Sheryl N. Hamilton. "Trafficking in the Zombie: The CDC Zombie Apocalypse Campaign, Diseaseability and Pandemic Culture." Refractory: A Journal of Entertainment Media 23 (2014) https://refractory-journal.com/cdc-zombie-apocalypsegerlach-hamilton/

Gersdorf, Catrin. The Poetics and Politics of the Desert: Landscape and the Construction of America. Amsterdam: Rodopi, 2008.

Ginzburg, Carlo. Threads and Traces: True False Fictive, translated by Anne C. Tedeschi. Berkeley, CA: The University of California Press, 2012.

Godelier, Maurice. L'imaginé, l'imaginaire et le symbolique. Paris: CNRS, 2015. 


\section{Bibliography}

Gomel, Elana. "The Plague of Utopias: Pestilence and the Apocalyptic Body." Twentieth Century Literature 46(4) Literature and Apocalypse (2000): 405-433.

Gooding, Francis. "Feathered, Furred or Coloured." The London Review of Books 40(4) (February 22, 2018): 14-16.

Gould, George M. An Illustrated Dictionary of Medicine, Biology and Allied Sciences. Philadelphia: P. Blakiston, Son \& Co, 1894.

Guitton, Matthieu J. and Cecile Cristofari. "Does Surviving the Zombie Apocalypse Represent a Good Model of Human Behaviour in Response to Pandemics?" Journal of Public Health Management Practice 20(4) (2014): 375-377.

Guterl, F. The Fate of the Species: Why the Human Race May Cause Its Own Extinction and How We Can Stop It. London and New York: Bloomsbury, 2012.

Halabi, Monique, Alexander Dao, Kyle Chen and Brandon Brown. "Zombies: A Pop Culture Resource for Public Health Awareness.” Emerging Infectious Diseases 19(5) (2013): 809-813.

Hanson, Ben. "The Story and Environments of the Last of Us." Gameinformer, February 8, 2012 www.gameinformer.com/b/features/archive/2012/02/08/the-story-and-environmentsof-the-last-of-us.aspx

Haraway, Donna. Staying with the Trouble: Making Kin in the Chthulucene. Durham, NC: Duke University Press, 2016.

Hardy, Anne. "Animals, Disease and Man: Making Connections." Perspectives in Biology and Medicine 46(2) (Spring 2003): 200-215.

Harper, Kyle. "How Microbes Have Destroyed Civilisations in Catastrophic Biological Events.” Star2, December 16, 2017 www.star2.com/health/2017/12/16/microbes-candestroy-civilisations/\#SWPAUfAODChlrUcc.99

Harrison, Mark. "Tropical Medicine in Nineteenth-Century India." British Journal for the History of Science 25 (1992): 299-318.

Harrison, Mark. Contagion: How Commerce Has Spread Disease. New Haven: Yale University Press, 2012.

Harrison, Mark. "Pandemics." In The Routledge History of Disease, edited by M. Jackson, 129-146. London and New York: Routledge, 2017.

Hasian, Marouf A. Representing Ebola: Culture, Law, and Public Discourse about the 2013-2015 West African Ebola Outbreak. Madison, NJ: Fairleigh Dickinson University Press, 2016.

Hassan, Zaiton, E. Purwati, Son Radu, R. A. Rahim, and G. Rusul. "Prevalence of Listeria spp and Listeria Monocytogenes in Meat and Fermented Fish in Malaysia". Southeast Asian Journal of Tropical Medicine and Public Health, 32(2) (2001): 402-407.

Haynes, Douglas M. Imperial Medicine: Patrick Manson and the Conquest of Tropical Disease. Philadelphia: University of Pennsylvania Press, 2001.

Heesterbeek, J. A. P. and Klaus Dietz. "The Concept of $R 0$ in Epidemic Theory." Statistica Neerlandica 50(1) (1996): 89-110.

Heffernan, M., R. J. Smith and L. M. Wahl. "Perspectives on the Basic Reproductive Ratio." Journal of the Royal Society Interface 2(4) (2005): 281-293.

Heise, Ursula K. Imagining Extinction: The Cultural Meanings of Endangered Species. Chicago: The University of Chicago Press, 2016.

Hell, Julia. "Katechon: Carl Schmitt's Imperial Theology and the Ruins of the Future." The Germanic Review: Literature, Culture, Theory 84(4) (2009): 283-326.

Hellerman, Caleb. "How 'Contagion' Spread to the Big Screen.” CNN, September 14, 2011 http://edition.cnn.com/2011/09/13/health/contagion-big-screen/

Heller-Roazen, Daniel. The Enemy of All: Piracy and the Law of Nations. Cambridge, MA: MIT Press, 2009. 
Hill, Logan. "How to Build a True Urban Jungle." New York Magazine [undated] http:// nymag.com/movies/features/41551/

Hinchliffe, Steven, John Allen, S. Lavau, Nick Bingham and Simon Carter. "Biosecurity and the Topologies of Infected Life: From Borderlines to Borderlands." Transactions of the Institute of British Geographers 38(4) (October 2013): 531-543.

Hinchliffe, Steven, Nick Bingham, John Allen and Simon Carter. Pathological Lives: Disease, Space and Biopolitics. London: Wiley-Blackwell, 2016.

Holmes, Michael. "Baghdad Zoo: A Different Battle." CNN, April 17, 2003 http://edition. cnn.com/2003/WORLD/meast/04/16/sprj.nilaw.baghdad.zoo/

Holowchak, Mark. "Interpreting Dreams for Corrective Regimen: Diagnostic Dreams in Greco-Roman Medicine." Journal of the History of Medicine and Allied Sciences 56(4) (October 2001): 382-399.

Honigsbaum, Mark. “'Tipping the balance': Karl Friedrich Meyer, Latent Infections, and the Birth of Modern Ideas of Disease Ecology.” Journal of the History of Biology (2015) doi:10.1007/s10739-015-9430-7

House of Commons Parliamentary Papers [C.2262]. "Parliamentary Session: 1878-79, Plague." Papers relating to the Modern History and Recent Progress of Levantine Plague: Prepared from Time to Time by Direction of the President of the Local Government Board, with Other Papers.

How It Should Have Ended. "How World War Z Should Have Ended." YouTube, October 29, 2013 www.youtube.com/watch?v=Ow2Uh51IMh4

Huddleston, Chad. “Are You Prepared for Zombies?" American Anthropological Association Blog, April 11, 2012 htpp://blog.aaanet.org/2012/04/11/are-you-prepared-for-zombies

Hughes Fowler, B. "The Imagery of the Prometheus Bound." The American Journal of Philology 78(2) (1957): 173-184.

Hulak, Florence. "Que permet de penser le concept d'imaginaire social de Charles Taylor?"Philosophiques 37(2) (Fall 2010): 275-585.

Hulskamp, Maithe Armido Aroesja. "Sleep and Dreams in Ancient Medical Diagnosis and Prognosis." PhD diss., Newcastle University, 2008.

Hustis, Harrier. "Responsible Creativity and the 'Modernity' of Mary Shelley's Prometheus." SEL Studies in English Literature 1500-1900 43(4) (Autumn 2003): 845-858.

India Office Records and Private Papers. Mahamari Disease [Fever] Prevailing in Garhwal. British Library IOR/F/4/2472/138452: 1836-1851.

Ingold, Tim. Lines: A Brief History. London and New York: Routledge, 2007.

Ingold, Tim. "Anthropology Contra Ethnography." HAU: Journal of Ethnographic Theory 7(1) (2017): 21-26.

Irving, Andrew. "Granite and Steel." In Reflections on Imagination. Human Capacity and Ethnographic Method, edited by Mark Harris and Nigel Rapport, 135-160. Farnham: Ashgate, 2015.

Jameson, Fredric. The Seeds of Time. New York: Columbia University Press, 1994.

Jameson, Fredric. "Future City." New Left Review 21 (May-June 2003): 65-79.

Jasanoff, Sheila and Sang-Hyun Kim (eds.). Dreamscapes of Modernity: Sociotechnical Imaginaries and the Fabrication of Power. Chicago: The University of Chicago Press, 2015.

Jay, Martin. "The Apocalyptic Imagination and the Inability to Mourn." In Rethinking Imagination: Culture and Creativity, edited by Gillian Robinson and John F. Rundell, 30-47. London and New York: Routledge, 1994.

Jha, Alok. "A Deadly Disease Could Travel at Jet Speed around the World: How Do We Stop It in Time?" The Guardian, November 12, 2013 www.theguardian.com/science/2013/ nov/12/deadly-disease-modern-global-epidemic 


\section{6}

Jonas, Hans. The Imperative of Responsibility: In Search of an Ethics for the Technological Age. Chicago: The University of Chicago Press, 1985.

Jones, Susan D. and Anna A. Amramina. "Entangled Histories of Plague Ecology in Russia and the USSR." History and Philosophy of the Life Sciences 40(49) (2018) https://doi. org/10.1007/s40656-018-0220-3

Jung, Susan. "Selfie Frenzy as Jamie Oliver Tours Hong Kong Market and Restaurants." The South China Morning Post, March, 24, 2015 www.scmp.com/lifestyle/arts-culture/ article/1746348/selfie-frenzy-jamie-oliver-tours-hong-kong-market-and

Kamper, Dietmar. "Between Simulation and Negentropy: The Fate of the Individual in Looking Back on the End of the World", translated by David Antal. In Looking Back at the End of the World, edited by Dietmar Kamer and Christoph Wulf, 96-105. New York: Semiotext(e), 1989.

Karp, Andrew. "The Disease of Inflexibility in Aeschylus' 'Prometheus Bound'." Mediterranean Studies 6 (1996): 1-12.

Keck, Frédéric. "Une sentinelle sanitaire aux frontières du vivant: Les experts de la grippe aviaire à Hong Kong." Terrain 54 (2010): 26-41.

Keck, Frédéric. Un Monde Grippé. Paris: Flammarion, 2010.

Keck, Frédéric. Claude Lévi-Strauss, une introduction. Paris: Pocket, 2011.

Keck, Frédéric. "From Purgatory to Sentinel: 'Forms/Events' in the Field of Zoonoses." Cambridge Anthropology 32(1) (Spring 2014): 47-61.

Keck, Frédéric. "Untitled" [Comment to C. Caduff "Pandemic Prophecy, or How to Have Faith in Reason"]. Current Anthropology 55(3) (June 2014): 309.

Keck, Frédéric. "Ebola, entre science et fiction." Anthropologie \& Santé 11 (2015) doi: 10.4000/anthropologiesante. 1870

Keck, Frédéric. "L'alarme d'Antigone:les chimères des chasseurs de virus." Terrain 64 (2015): 3-19.

Keck, Frédéric. "Liberating Sick Birds: Poststructuralist Perspectives on the Biopolitics of Avian Influenza." Cultural Anthropology 30(2) (2015): 224-235.

Keck, Frédéric. "Sentinel Devices: Managing Uncertainty in Species Barrier Zones." In Modes of Uncertainty: Anthropological Cases, edited by Limor Samimian-Darash and Paul Rabinow, 165-181. Chicago: The University of Chicago Press, 2015.

Keck, Frédéric. "'Preparedness' Theorizing the Contemporary." Cultural Anthropology Website, September 30, 2016 https://culanth.org/fieldsights/961-preparedness

Keck, Frédéric. "Stockpiling as a Technique of Preparedness: Conserving the Past for an Unpredictable Future." In Cryopolitics: Frozen Life in a Melting World, edited by Joanna Radin and Emma Kowal, 117-142. Cambridge, MA: MIT Press, 2017.

Keck, Frédéric and Andrew Lakoff. "Figures of Warning." Limn 3 (June 2013) http://limn. it/figures-of-warning/

Keck, Frédéric and Christos Lynteris. "Zoonosis: Prospects and Challenges for Medical Anthropology." Medicine Anthropology Theory 5(3) (2018) https://doi.org/10.17157/mat.5.3.372

Keeling, Matt J. and Bryan T. Grenfell. "Individual-Based Perspectives on $\mathrm{R}_{0}$." Journal of Theoretical Biology 203 (2000): 51-61.

Keller, Catherine. Apocalypse Now and Then: A Feminist Guide to the End of the World. Minneapolis: Fortress Press, 1996.

Kerényi, Károly. Prometheus: Archetypal Image of Human Existence, translated by Ralph Manheim. Princeton: Princeton University Press, 1997 [1956].

Kermode, Frank. The Sense of an Ending: Studies in the Theory of Fiction. Oxford: Oxford University Press, 1966. 
Khan, Ali S. "Preparedness 101: Zombie Apocalypse." Centers for Disease Control and Prevention, Public Health Matters Blog, May 16,2011 https://blogs.cdc.gov/publichealthmatters/ 2011/05/preparedness-101-zombie-apocalypse/

Khan, Ali S. and William Patrick. The Next Pandemic: On the Front Lines against Humankind's Gravest Dangers. New York: PublicAffairs, 2016.

Kiku, Adato. Picture Perfect: Life in the Age of the Photo Op. Princeton: Princeton University Press, 2008.

King, Nicholas B. "Security, Disease, Commerce: Ideologies of Postcolonial Global Health." Social Studies of Science 32(5-6) Postcolonial Technoscience (October-December 2002): 763-789.

King, Nicholas B. "The Scale Politics of Emerging Diseases." Osiris 2nd Series 19 Landscapes of Exposure: Knowledge and Illness in Modern Environments (2004): 62-76

Klapp, Orrin. “Creation of Popular Heroes.” American Journal of Sociology 56 (1948): 135-141.

Klooger, Jeff. Castoriadis: Psyche, Society, Autonomy. Amsterdam: Brill Press, 2009.

Klooger, Jeff. "From Nothing: Castoriadis and the Concept of Creation." Critical Horizons a Journal of Philosophy and Social Theory 12(1) (2011): 29-47.

Kolbert, Elizabeth. The Sixth Extinction: An Unnatural History. New York: Henry Holt and Company, 2014.

Krauss, Rosalind. The Optical Unconscious. Cambridge, MA: MIT Press, 1993.

Kruvand, Marjorie and Maggie Silver. "Zombies Gone Viral: How a Fictional Invasion Helped CDC Promote Emergency Preparedness." Case Studies in Strategic Communication 2 (2013): 34-60.

Kuletz, Valerie. The Tainted Desert: Environmental Ruin in the American West. London and New York: Routledge, 1998.

Kupferschmidt, Kai. "Did Poor Ventilation Lead to MERS 'Superspread' in Korea?" Science (June 5 2015) doi:10.1126/science.aac6802

Lachenal, Guillaume. "Lessons in Medical Nihilism: Virus Hunters, Neoliberalism, and the AIDS Pandemic in Cameroon." In Para-States and Medical Science: Making African Global Health, edited by Paul Wenzel Geissler, 103-141. Durham, NC: Duke University Press, 2015.

Lakoff, Andrew. "The Generic Biothreat, or, How We Became Unprepared." Cultural Anthropology 23 (2008): 399-428.

Lahr, Angela M. Millennial Dreams and Apocalyptic Nightmares: The Cold War Origins of Political Evangelicalism. New York: Oxford University Press, 2007.

Lakoff, Andrew. "Toward a Genealogy of Global Health Security." In Contagion: Health, Fear Sovereignty, edited by Bruce Magnusson and Zahi A. Zalloua, 44-70. Seattle: University of Washington Press, 2012.

Lakoff, Andrew. Unprepared: Global Health in a Time of Emergency. Berkeley, CA: The University of California Press, 2017.

Lanci, Yari. "Zombie 2.0: Subjectivation in Times of Apocalypse." Journal for Cultural and Religious Theory 13(2) (Spring 2014): 25-37.

Latour, Bruno. The Pasteurization of France, translated by Alan Sheridan. Cambridge, MA: Harvard University Press, 1993.

Lau, M. "Angela Merkel Begins Visit to China with Trip to Sichuan Wet Market." The South China Morning Post, July 6, 2014 www.scmp.com/news/china/article/1548104/ angela-merkel-begins-visit-china-trip-sichuan-wet-market

Lau, Max S. Y., Benjamin Douglas Dalziel, Sebastian Funk, Amanda McClelland, Amanda Tiffany, Steven Riley, C. Jessica E. Metcalf and Bryan T. Grenfell. "Spatial and Temporal 


\section{Bibliography}

Dynamics of Superspreading Events in the 2014-2015 West Africa Ebola Epidemic." Proceedings of the National Academy of Sciences of the United States of America 114(9) (February 2017): 2337-2342.

Laurance, Jememy. "Sars Victim Who Infected 133 Will Remain in Quarantine." The Independent, April 10, 2003 www.independent.co.uk/news/science/sars-victim-whoinfected-133-will-remain-in-quarantine-114666.html

Lauro, Sarah Juliet (ed.). Zombie Theory: A Reader. Minneapolis: University of Minnesota Press, 2017.

Leach, Neal. Camouflage. Cambridge, MA: MIT Press, 2006.

Leakey, Richard and Robert Lewin. The Sixth Extinction: Patterns of Life and the Future of Humankind. New York: Anchor Books, 1995.

Lederberg, Joshua, Robert E. Shope and Stanley C. Oaks (eds.). Emerging Infections: Microbial Threats to Health in the United States. Washington, DC: National Academy Press, 1992.

Lennon, Kathleen. Imagination and the Imaginary. London and New York: Routledge, 2015.

Leslie, John. The End of the World: The Science and Ethics of Human Extinction. London and New York: Routledge, 1996.

Leung, P. C. and E. E. Ooi. SARS War. Hong Kong: World Scientific Publications, 2003.

Lévi-Strauss, Claude. "La leçon de sagesse des vaches folles." Etudes Rurales 157-158 (2001): 9-14.

Levitas, Ruth. "Educated Hope: Ernst Bloch on Abstract and Concrete Utopia." Utopian Studies 1(2) (1990): 13-26.

Levy, David L. and André Spicer. "Contested Imaginaries and the Cultural Political Economy of Climate Change.” Organisation 20(5) (September 2013): 659-678.

Leys Stepan, Nancy. Picturing Tropical Nature. London: Reaktion Books, 2001.

Li, Y., S. Duan, I. T. S. Yu and W. Wong. "Multi-Zone Modelling of Probable SARS Virus Transmission by Airflow Between Flats in Block E, Amoy Gardens." Indoor Air 15 (2004): 96-111.

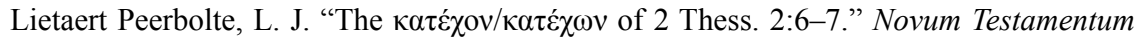
39(2) (April 1997): 138-150.

Liu, Sze-ki. "An Ethnographic Comparison of Wet Markets and Supermarkets in Hong Kong." The Hong Kong Anthropologist 2 (2008): 1-51.

Lloyd-Smith, John O., S. J. Schreiber, P. E. Kopp and W. M. Getz. "Superspreading and the Effect of Individual Variation on Disease Emergence." Nature 438(17) (November 17, 2005): 355-359.

Lock, Margaret. "Breast Cancer: Reading the Omens." Anthropology Today 14(4) (August 1998): 7-16.

London, Jack. The Scarlet Plague. Croydon: Hesperus Press, 2013.

Long, Thomas L. AIDS and American Apocalypticism: The Cultural Semiotics of an Epidemic. New York: State University of New York Press, 2005.

Lovgren, S. "The Mystery of the SARS Virus: How Is It Spread?" National Geographic News, April 9, 2003 http://news.nationalgeographic.com/news/2003/04/0409_030409_ sars.html

Lowe, Celia. "Viral Clouds: Becoming H5N1 in Indonesia." Cultural Anthropology 25(4) (2010): 625-649.

Lynch, Lisa. "The Neo/Bio/Colonial hot Zone: African Viruses, American Fairytales." International Journal of Cultural Studies 1(2) (1998): 163-196. 
Lynteris, Christos (ed.). Cambridge Anthropology 32(1) Epidemic Events and Processes (March 2014).

Lynteris, Christos. Ethnographic Plague: Configuring Disease on the Chinese-Russian Frontier. London: Palgrave Macmillan, 2016.

Lynteris, Christos. "The Prophetic Faculty of Epidemic Photography: Chinese Wet Markets and the Imagination of the Next Pandemic." Visual Anthropology 29(2) Medicine, Photography and Anthropology (2016): 118-132.

Lynteris, Christos. "A Suitable Soil: Plague's Breeding Grounds at the Dawn of the Third Pandemic.” Medical History 61(3) (June 2017): 343-357.

Lynteris, Christos. "Zoonotic Diagrams: Mastering and Unsettling Human-Animal Relations." Journal of the Royal Anthropological Institute N.S. 23(3) (September 2017): 463-485.

Lynteris, Christos. "The Frankfurt School, Critical Theory and Anthropology." In Schools and Styles of Anthropological Theory, edited by Matei Candea, 159-172. London and New York: Routledge, 2018.

Lynteris, Christos. "Pestis Minor: The History of a Contested Pathology." Bulletin of the History of Medicine 93(1) (2019): 55-81.

Lynteris, Christos. "Plague Masks: The Visual Emergence of Anti-Epidemic Personal Protection Equipment." Medical Anthropology 37 (2018): 442-457.

Lynteris, Christos. "Yellow Peril Epidemics: The Political Ontology of Degeneration and Emergence." In Yellow Perils: China Narratives in the Contemporary World, edited by Frank Billé and Soren Urbansky 35-59. Honolulu: Hawaii University Press 2018.

Lynteris, Christos and Nicholas H. Evans. "Introduction: The Challenge of the Epidemic Corpse." In Histories of Post-Mortem Contagion: Infectious Corpses and Contested Burials, edited by Christos Lynteris and Nicholas H. Evans, 1-25. London: Palgrave Macmillan, 2018.

MacPhail, Theresa. "A Predictable Unpredictability: The 2009 H1N1 Pandemic and the Concept of 'Strategic Uncertainty' within Global Public Health.” Behemoth 3 (2010): 57-77.

Magnusson, Bruce and Zahi A. Zalloua. "Introduction: The Hydra of Contagion." In Contagion: Health, Fear Sovereignty, edited by Bruce Magnusson and Zahi A. Zalloua, 3-24. Seattle: University of Washington Press, 2012.

Manjikian, Mary. Apocalypse and Post-Politics: The Romance of the End. Lanham: Lexington Books, 2012.

Marcus, George E. (ed.). Technoscientific Imaginaries: Conversations, Profiles, and Memoirs. Chicago: The University of Chicago Press, 1994.

Martin, Andrew. "The Scientific A-Team Saving the World from Killer Viruses, Rogue AI and the Paperclip Apocalypse." The Guardian, August 30, 2014 www.theguardian.com/ technology/2014/aug/30/saviours-universe-four-unlikely-men-save-world

Martin, Emily. Flexible Bodies: Tracking Immunity in American Culture from the Days of Polio to the Age of AIDS. Boston: Beacon Press, 1994.

Martin, Sean. "Apocalypse Warning: Ancient Viruses Could REAWAKEN and Cause Global Epidemic." The Express, May 10,2017 www.express.co.uk/news/science/802779/ Apocalypse-warning-Ancient-virus-arctic-permafrost

Martuccelli, Danilo. "Cornelius Castoriadis: promesses et problèmes de la creation." Cahiers internationaux de sociologie 2(113) (2002): 285-305.

Masco, Joseph. The Nuclear Borderlands: The Manhattan Project in Post-Cold War New Mexico. Princeton: Princeton University Press, 2006.

Masco, Joseph. "'SurvivalIs Your Business': Engineering Ruins and Affect in Nuclear America." Cultural Anthropology 23(2) (May 2008): 361-398. 
Masco, Joseph. “The End of Ends.” Anthropological Quarterly 85(4) (Fall 2012): 1107-1124.

Masco, Joseph. "Catastrophe's Apocalypse." In The Time of Catastrophe: Multidisciplinary Approaches to the Age of Catastrophe, edited by Christopher Dole, Robert Hayashi, Andrew Poe and Austin Sarat, 19-46. London and New York: Routledge, 2015.

Mason, Katherine A. Infectious Change: Reinventing Chinese Public Health after an Epidemic. Stanford, CA: Stanford University Press, 2016.

Mattern, Susan P. Prince of Medicine: Galen in the Roman World. Oxford: Oxford University Press, 2013.

McCollom, Molly. "DragonKhan." Centers for Disease Control and Prevention, Public Health Matters Blog, October 2011 http://blogs.cdc.gov/publichealthmatters/2011/10/ dragonkhan/

McEuen, Paul L. "Science Fiction: A Post-Pandemic Wilderness.” Nature 500(398-399) (22 August 2013) doi:10.1038/500398a

McGinn, Bernard. Visions of the End: Apocalyptic Traditions in the Middle Ages. New York: Columbia University Press, 1979.

McNeil, Donald G. and Lawrence K. Altman. "How One Person Can Fuel an Epidemic." New York Times, April 15, 2003 www.nytimes.com/2003/04/15/science/how-one-personcan-fuel-an-epidemic.html

Merchant, Carolyn. Reinventing Eden: The Fate of Nature in Western Culture. London and New York: Routledge, 2003.

Metger, Paul. Katechon: II Thess 2.1-12 im Horizont apokalyptischen Denkens. Berlin: Walter de Gruyter, 2005.

Meyer, Karl F. "Sylvatic Plague." American Journal of Public Health 28(10) (1938): 1153-1164.

Meyer, Karl F. "The Ecology of Plague.” Medicine 21(2) (1942): 143-174.

Meyer, Robinson. "Human Extinction Isn't That Unlikely." The Atlantic, April 29, 2016 www.theatlantic.com/technology/archive/2016/04/a-human-extinction-isnt-thatunlikely/480444/

Michoud, J. L. "Report on the Health of Mengtsz for the Year Ended 30thApril 1894." China Imperial Maritime Customs Medical Reports, 1894, Special Series, No. 2.

Mitchell, Peta. Contagious Metaphor. London and New York: Bloomsbury, 2012.

Mitchell, Scott and Sheryl N. Hamilton. "Playing at Apocalypse: Reading Plague Inc. in Pandemic Culture." Convergence: The International Journal of Research into New Media Technologies (17 January 2017) https://doi.org/10.1177/1354856516687235

Mitchell, William J. T. The Last Dinosaur Book: The Life and Times of a Cultural Icon. Chicago: The University of Chicago Press, 1998.

Mitchell-Boyask, Robin. Plague and the Athenian Imagination. Cambridge: Cambridge University Press, 2007.

Mollaret, Henri H. and Jacqueline Brossollet. Yersin: Un pasteurien en Indochine. Paris: Belin, 2017.

Moore, Henrietta L. The Subject of Anthropology: Gender, Symbolism and Psychoanalysis. London: Polity Press, 2007.

Morris, Ian. "Plagues and Socioeconomic Collapse." In Plagues, edited by Jonathan L. Heeney and Sven Friedemann, 136-167. Cambridge: Cambridge University Press, 2017.

Morse, Stephen S. "Factors in the Emergence of Infectious Diseases." Emerging Infectious Diseases 1(1) (1995): 7-15.

Morton, Timothy. Hyperobjects: Philosophy and Ecology after the End of the World. Minneapolis: University of Minnesota Press, 2013. 
Morton, Timothy. Dark Ecology: For a Logic of Future Coexistence. New York: Columbia University Press, 2016.

Morton, Timothy. Humankind: Solidarity with Nonhuman People. London: Verso, 2017.

Mossman, J. M. "Chains of Imagery in Prometheus Bound." The Classical Quarterly 46(1) (1996): 58-67.

Motti, Claudia. "Le germe et le kratos: Réflexions sur la creation politique à Athènes." In Cornelius Castoriadis, Ce qui fait la Grèce: Tome 3, Thucydide, la force et le droit, 13-26. Paris: Seuil, 2011.

Mouzakitis, Angelos. "Creation ex nihilo." In Cornelius Castoriadis Key Concepts, edited by Suzi Adams, 53-64. London and New York: Bloomsbury, 2014.

Mukharji, Projit Bihari. "Cat and Mouse: Animal Technologies, Trans-Imperial Networks and Public Health from Below, British India, c. 1907-1918." Social History of Medicine 31(3) (2017): 510-532.

Mulhall, Stephen. On Film. London and New York: Routledge, 2001.

Müller, Christopher John. Prometheanism: Technology, Digital Culture and Human Obsolescence. Lanham: Rowman and Littlefield, 2016.

Munro, Martin. Tropical Apocalypse: Haiti and the Caribbean End Times. Charlottesville: University of Virginia Press, 2015.

Myerhoff, Barbara G. and William R. Larson. "The Doctor as Culture Hero: The Routinization of Charisma." Human Organization 24 (1965): 188-191.

Myers, Norman. "An Expanded Approach to the Problem of Disappearing Species." Science N.S. 193(4229) (1976): 198-202.

Myers, Norman. The Sinking Ark: A New Look at the Problem of Disappearing Species. Oxford: Pergamon Press, 1979.

Nancy, Jean-Luc. After Fukushima: The Equivalence of Catastrophes. New York: Fordham University Press, 2014.

Naphy, William G. Plagues, Poisons and Potions: Plague-Spreading Conspiracies in the Western Alps c. 1530-1640. Manchester: Manchester University Press, 2001.

Napier, A. David. Masks, Transformation, and Paradox. Berkeley, CA: The University of California Press, 1986.

Napier, A. David. "Penser 'vaccinologiquement': une sélection qui n'est pas vraiment naturelle." In L'Aventure de la vaccination, edited by Anne-Marie Moulin. Paris: Fayard, 1996.

Napier, A. David. The Age of Immunology: Conceiving a Future in an Alienating World. Chicago: The University of Chicago Press, 2002.

Napier, A. David. "Epidemics and Xenophobia, or, Why Xenophilia Matters." Social Research: An International Quarterly 84(1) (Spring 2017): 59-81.

Narat, Victor, Lys Alcayna-Stevens, Stephanie Rupp and Tamara Giles-Vernick. "Rethinking Human: Nonhuman Primate Contact and Pathogenic Disease Spillover." EcoHealth 14(4) (2017): 840-850.

Nardelli, Matilde. "No End to the End: The Desert as Eschatology in Late Modernity." Tate Papers 22 (Autumn 2014) www.tate.org.uk/research/publications/tate-papers/22/ no-end-to-the-end-the-desert-as-eschatology-in-late-modernity

Navaro-Yashin, Yael. "Affective Spaces, Melancholic Objects: Ruination and the Production of Anthropological Knowledge." Journal of the Royal Anthropological Institute N.S. 15(1) (March 2009): 1-18.

Neyrat, Cyril. "L'arche et le Titanic. Films-catastrophe et cinema du desastre." Critique 783-784 Penser la Catastrophe (aout-septembre 2012): 739-753. 


\section{Bibliography}

Nishiura, Hiroshi, Akira Endo, Masaya Saitoh, Ryo Kinoshita, Ryo Ueno, Shinji Nakaoka, Yuichiro Miyamatsu, Yueping Dong, Gerardo Chowell, Kenji Mizumoto. "Identifying Determinants of Heterogeneous Transmission Dynamics of the Middle East Respiratory Syndrome (MERS) Outbreak in the Republic of Korea, 2015: A Retrospective Epidemiological Analysis.” The British Medical Journal Open 6 (2016): e009936. doi:10.1136/ bmjopen-2015-009936

Nixon, Kari and Lorenzo Servitje (eds.). Endemic: Essays in Contagion Theory. London: Palgrave Macmillan, 2016.

Noël, Romain. "Une science mélancolique.” Critique 860-861 (2019): 136-150.

Normille, Dennis. "Understanding the Enemy." Science 339(6125) (15 March 2013): $1269-1273$.

North Manchurian Plague Prevention Service. "The Role of the Tarbagan in the Epidemiology of Plague.” North Manchurian Plague Prevention Service Reports (1918-1922): 83-98.

Noury, Mathieu. "Cornelius Castoriadis, Sociologue? Critique sociologique del'ontologie de la création imaginaire sociale." Aspects Sociologiques 18(1) (2011): 77-78.

Okely, Judith. Anthropological Practice: Fieldwork and the Ethnographic Method. London: Berg, 2012.

Orwin, Clifford. "Stasis and Plague: Thucydides on the Dissolution of Society." The Journal of Politics 50(4) (November 1988): 831-847.

Osborne, Michael A. "Acclimatizing the World: A History of the Paradigmatic Colonial Science." Osiris 15 (2000): 135-151.

Osborne, Michael A. The Emergence of Tropical Medicine in France. Chicago: The University of Chicago Press, 2014.

Ostherr, Kirsten. Cinematic Prophylaxis: Globalization and Contagion in the Discourse of World Health. Durham, NC: Duke University Press, 2005.

Packard, Randall M. The Making of a Tropical Disease: A Short History of Malaria. Baltimore: Johns Hopkins University Press, 2007.

Paik, Peter Y. From Utopia to Apocalypse: Science Fiction and the Politics of Catastrophe. Minneapolis: University of Minnesota Press, 2010.

Pavese, Cesare. "Concerning Certain Poems Not Yet Written." In Cesare Pavese Selected Poems, translated by Margaret Crosland. London: Penguin, 1969 [1943].

Peard, Julyan G. Race, Place and Medicine: The Idea of the Tropics in 19th Century Brazilian Medicine. Durham, NC: Duke University Press, 1999.

Peckham, Robert. "Infective Economies: Empire, Panic, and the Business of Disease." Journal of Imperial and Commonwealth History 41(2) (2013): 211-237.

Peckham, Robert. "Matshed Laboratory: Colonies, Cultures, and Bacteriology.” In Imperial Contagions: Medicine, Hygiene, and Cultures of Planning in Asia, edited by Robert Peckham and David M. Pomfret, 123-150. Hong Kong: Hong Kong University Press, 2013.

Peckham, Robert. "Game of Empires: Hunting in Treaty-Port China." In Eco-Cultural Networks and the British Empire, edited by James Beattie, Edward Mellilo and Emily O'Gorman, 202-232. London and New York: Bloomsbury, 2014.

Pemberton, Neil. "The Rat-Catcher's Prank: Interspecies Cunningness and Scavenging in Henry Mayhew's London.” Journal of Victorian Culture 19(4) (2014): 520-535.

Pensky, Max. "Method and Time: Benjamin's Dialectical Images." In The Cambridge Companion to Walter Benjamin, edited by D. S. Ferris, 177-198. Cambridge: Cambridge University Press, 2004.

Perrey, Christophe. Un ethnologue chez les chasseus de virus. Enquête en Guyane française. Paris: L'Harmattan, 2012. 
Petryna, Adriana and Paul Wolff Mitchell. "On the Nature of Catastrophic Forms.” BioSocieties 12(3) (March 2017): 1-24.

Philmus, Robert M. and David Y. Hughes (eds.). H. G. Wells: Early Writings in Science and Science Fiction. Berkeley, CA: The University of California Press, 1975.

Pink, Sarah, Yoko Akama and Annie Fergusson. "Researching Future as an Alterity of the Present." In Anthropologies and Futures: Researching Emerging and Uncertain World, edited by Juan Francisco Salazar, Sarah Pink, Andrew Irving and Johannes Sjöberg, 133-150. London and New York: Bloomsbury, 2017.

Pinney, Christopher. "The Prosthetic Eye: Photography as Cure and Poison." Journal of the Royal Anthropological Institute 14(S1) (April 2008): 33-46.

Poindexter, Mark. "Apocalyptic Dread and the Planet of the Apes." In Apocalyptic Chic: Visions of the Apocalypse and Post-Apocalypse in Literature and Visual Arts, edited by Barbara Brodman and James E. Doan, 165-182. Madison, NJ: Fairleigh Dickinson University Press, 2018.

Poirier, Nicholas. L'ontologie politique de Castoriadis. Création et institution. Paris: Payot, 2011.

Poirier, Nicolas. "Castoriadis et l'imaginaire radical: Une confrontation avec la phénoménologie.” Bulletin d'analyse phénoménologique XIII 2(Actes 10) (2017): 458-477.

Poleykett, Branwyn. "Building Out the Rat: Animal Intimacies and Prophylactic Settlement in 1920s South Africa." February 7, 2017 https://aesengagement.wordpress.com/ 2017/02/07/building-out-the-rat-animal-intimacies-and-prophylactic-ssettlement-in1920s-south-africa/

Porter, Natalie. "Bird Flu Biopower: Strategies for Multispecies Coexistence in Việt Nam." American Ethnologist 40(1) (2013): 132-148.

Preston, Richard. "Crisis in the Hot Zone." New Yorker (26 October 1992): 58.

Preston, Richard. The Hot Zone. New York: Anchor, 1994.

Quamenn, David. Spillover: Animal Infections and the Next Human Pandemic. London: W. W. Norton\& Co., 2012.

Quamenn, David. Ebola: The Natural and Human History. London: The Bodley Head, 2014.

Rabinow, Paul. Essays on the Anthropology of Reason. Princeton: Princeton University Press, 1996.

Radin, Joanna. "Never Ending Stories: Narrating Frozen Evidence of Infectious Epidemics Past." Somatosphere, Science, Medicine, and Anthropology, June 22, 2016 http:// somatosphere.net/2016/06/never-ending-stories-narrating-frozen-evidence-ofinfectious-epidemics-past.html

Raggio, Olga. "The Myth of Prometheus: Its Survival and Metamorphoses up to the Eighteenth Century." Journal of the Warburg and Courtauld Institutes 21(1/2) (January-June 1958): 44-62.

Rennie, Alexander. "Report on the Plague Prevailing in Canton during the Spring and Summer of 1894." Imperial Customs Maritime Report for the Year Ended 30th September, 1894,47 th and 48th issues.

Reynolds Whyte, Susan. Questioning Misfortune: The Pragmatics of Uncertainty in Eastern Uganda. Cambridge: Cambridge University Press, 1997.

Rheinberger, Hans-Jörg. Toward a History of Epistemic Things: Synthesizing Proteins in the Test Tube. Stanford, CA: Stanford University Press, 1997.

Richter, Gerhard. "A Matter of Distance: Benjamin's One-Way Street through The Arcades." In Walter Benjamin and the Arcades Project, edited by B. Hanseen, 132-256. London and New York: Continuum, 2005. 


\section{Bibliography}

Ricoeur, Paul and Cornelius Castoriadis. "Dialogue on History and the Social Imaginary." In Ricoeur and Castoriadis in Discussion: On Human Creation, Historical Novelty and the Social Imaginary, edited by Suzi Adams, 3-20. Lanham: Rowman and Littlefield, 2017.

Riffel, Casey R. "Animals at the End of the World: Notes toward a Transspecies Eschatology." In Making Animal Meaning, edited by Linda Kalof and Georgina M. Montgomery, 159-172. East Lansing: Michigan State University Press, 2011.

Robinson, Tony. "Foreword." In Jack London, The Scarlet Plague. Croydon: Hesperus Press, 2013.

Rocher, Emile. La Province Chinoise du Yunnan. Paris: Lerous, 1879.

Rogaski, Ruth. Hygienic Modernity, Meaning of Health and Disease in Treaty-Port China. Berkeley, CA: The University of California Press, 2004.

Rogaski, Ruth. "Vampires in Plagueland: The Multiple Meanings of Weisheng in Manchuria." In Health and Hygiene in Chinese East Asia: Policies and Publics in the Long Twentieth Century, edited by Angela K. Ch. Leung and Charlotte Furth, 132-159. Durham, NC: Duke University Press, 2011.

Rogers, Leonard and J. W. D. Megaw. Tropical Medicine. London: J. \& A. Churchill, 1930.

Rollins, James. The 6th Extinction: A SIGMA Force Novel. New York: William Morrow \& Company, 2014.

Rosaldo, Renato. Culture and Truth: The Remaking of Social Analysis. Boston: Beakon Press, 1993.

Rose, Deborah, Tom Van Dooren and Matthew Chrulew. "Telling Extinction Stories." In Extinction Studies: Stories of Time, Death, and Generations, edited by Deborah Rose, Tom Van Dooren and Matthew Chrulew. New York: Columbia University Press, 2017.

Rosen, Elizabeth K. Apocalyptic Transformation: Apocalypse and the Postmodern Imagination. Lanham: Lexington Books, 2008.

Rosenberg, Charles E. "What Is an Epidemic? AIDS in Historical Perspective." Daedalus 118(2) Living with AIDS (Spring 1989): 1-17.

Rosenthal, Peggy. "The Nuclear Mushroom Cloud as Cultural Image." American Literary History 3(1) (Spring 1991): 63-92.

Ross, Corey. "Tropical Nature as Global Patrimoine: Imperialism and International Nature Protection in the Early Twentieth Century." Past \& Present 226(S10) (January 2015): 214-239.

Rova, Michele Augusto, Marta Benedetti and Giancarlo Cesana. "Pandemic Fear and Literature: Observations from Jack London's the Scarlet Plague." Emerging Infectious Diseases 20(10) (October 2014): 1753-1757.

Roy, Rohan Deb. "Nonhuman Empires, Comparative Studies of South Asia." Africa and the Middle East 35(1) (May 2015): 66-75.

Rumpala, Yannick. "Que faire face à l'apocalypse? Sur les représentations et les ressources de la science-fiction devant la fin d'un monde." Questions de communication 30 (2016): 309-334.

Samimian Darash, Limor. "A Pre-Event Configuration for Biological Threats: Preparedness and the Constitution of Biosecurity Events." American Ethnologist 36(3) (2009): 478-491.

Samimian Darash, Limor. "Governing Future Potential Biothreats: Toward an Anthropology of Uncertainty." Current Anthropology 54(1) (2013): 1-22.

Sampson, Tony D. Virality: Contagion Theory in the Age of Networks. Minneapolis: University of Minnesota Press, 2012.

Sanford, Sarah, Jessica Polzer and Peggy McDonough. "Preparedness as a Technology of (In)security: Pandemic Influenza Planning and the Global Biopolitics of Emerging Infectious Disease." Social Theory \& Health 14(1) (2016): 18-43. 
Sartre, Jean-Paul. The Imaginary: A Phenomenological Psychology of the Imagination. London and New York: Routledge, 2001 [1940].

Sayer, Karen. "The 'Modern' Management of Rats: British Agricultural Science in Farm and Field during the Twentieth Century." British Journal for the History of Science 2 (2017): 235-263.

Scafi, Alessandro. Mapping Paradise: A History of Heaven on Earth. London: The British Library, 2006.

Schell, Heather. "Outburst! A Chilling Story about Emerging-Virus Narratives and Pandemic Social Change.” Configurations 5(1) (Winter 1997): 93-133.

Scherpe, Klaus R. and Brent O. Peterson. "Dramatization and De-Dramatization of "the End': The Apocalyptic Consciousness of Modernity and Post-Modernity." Cultural Critique 5 (1986): 95-129.

Scholem, Gershom. The Messianic Idea in Judaism: And Other Essays on Jewish Spirituality. New York: Schocken, 1995.

Schuster, Joshua. "Life after Extinction." Parrhesia 27 (2017): 88-115.

Schweitzer, Dhalia. "Pushing Contagion: How Government Agencies Shape Portrayals of Disease." The Journal of Popular Culture 50(3) (2017): 445-465.

Schweitzer, Dhalia. Going Viral: Zombies, Viruses, and the End of the World. New Brunswick: Rutgers University Press, 2018.

Scranton, Roy. "Apocalypse." Theorizing the Contemporary, Cultural Anthropology Website, June 28, 2017 https://culanth.org/fieldsights/1151-apocalypse

Scutti, Susan and Bijan Hosseini. "Mystery Illness Claims 12 Lives in Liberia." CNN, May 5, $2017 \mathrm{http}: / /$ edition.cnn.com/2017/05/01/health/liberia-mystery-illness-who/

Serres, Michel. Parasite. Minneapolis: University of Minnesota Press, 2007.

Servitje, Lorenzo. "H5N1 for Angry Birds: Plague Inc., Mobile Games, and the Biopolitics of Outbreak Narratives." Science Fiction Studies 43(1) Digital Science Fiction (March 2016): 85-103.

Severi, Carlo. L'objet-personne: Une anthropologie de la croyance visuelle. Paris: Rue d'Ulm-Musée du quai Branly, 2017.

Shah, Nayan. Contagious Divides: Epidemics and Race in San Francisco's Chinatown. Berkeley, CA: The University of California Press, 2001.

Shaviro, Steven. The Cinematic Body. Minneapolis: University of Minnesota Press, 1993.

Sheasby, Walt. "Anti-Prometheus, Post-Marx: The Real and the Myth in Green Theory." Organization \& Environment 12(1) (March 1999): 5-44.

Shelley, Mary. The Last Man. Ware: Wordsworth, 2004 [1826].

Shen, Zhuang, Fang Ning, Weigong Zhou, Xiong He, Changyin Lin, Daniel P. Chin, Zonghan Zhu and Anne Schuchat. "Superspreading SARS Events, Beijing, 2003." Emerging Infectious Diseases 10(2) (February 2004): 25-260.

Silver, Maggie. Preparedness 101: Zombie Pandemic. Atlanta: Centers for Disease Control, U.S. Department of Health and Human Services, 2011.

Simond, Marc, Margaret L. Godley and Pierre D. E. Mouriquand. "Paul-Louis Simond and His Discovery of Plague Transmission by Rat Fleas: A Centenary." Journal of the Royal Society of Medicine 91(2) (February 1998): 101-104.

Singer, Brian. "The Later Castoriadis: Institution Under Interrogation." Canadian Journal of Political and Social Theory 4(1) (Winter 1980): 75-101.

Singer, Merrill. Introduction to Syndemics: A Critical Systems Approach to Public and Community Health. San Francisco: Jossey-Bass, 2009.

Singh, Julietta. Unthinking Mastery: Dehumanism and Decolonial Entanglements. Durham, NC: Duke University Press, 2017. 
Skrimshire, Stefan (ed.). Future Ethics: Climate Change and Apocalyptic Imagination. London and New York: Continuum, 2010.

Slater, Candace. "Amazonia as Edenic Narrative." In Uncommon Ground: Rethinking the Human Place in Nature, edited by William Cronon. New York: W.W. Norton \& Co., 1996.

Slomann, Vilheml. Bicorporates: Studies in Revivals and Migrations of Art Motifs. Copenhagen: Munksgaard, 1967.

Słotwińska, Karolina. "The Rising Multitude: Zombie Invasion and the Problem of Biopolitics in Max Brooks's World War Z.” Polish Journal for American Studies 9 (2015): $151-164$.

Smets, A. James Elkins, Catherine Burdick, Aud Sissel Hoel, Elizabeth Birk, Rachel Mundy, Regan Golden-McNerney, Mari-Jose Mondzain, Tom Mitchell, Joel Snyder, Merel Van Tilbirg and Si Han. "Image Notation, Graph . . ." In What Is an Image?, edited by James Elkins and Maja Naef, 91-104. University Park: Pennsylvania State University Press, 2011.

Smith, Michael. "SARS Lessons: Stay Alert for Emerging Pathogens." Medpage Today, April 22, 2013 www.medpagetoday.com/InfectiousDisease/Surveillance/38611

Smith, Shawn Michelle. At the Edge of Sight: Photography and the Unseen. Durham, NC: Duke University Press, 2013.

Smith, Shawn Michelle (ed.). Photography and the Optical Unconscious. Durham, NC: Duke University Press, 2017.

Sneath, David, Martin Holbraad and Morten Axel Pedersen. "Technologies of the Imagination: An Introduction." Ethnos 74(1) (2006): 5-30.

Sodikoff, Genese Marie. "Introduction: Accumulating Absence: Cultural Products of the Sixth Extinction." In The Anthropology of Extinction: Essays on Culture and Species Death, edited by Genese Marie Sodikoff, 1-16. Bloomington and Indianapolis: Indiana University Press, 2012.

Sodikoff, Genese Marie. “The Multispecies Infrastructure of Zoonosis.” In The Anthropology of Epidemics, edited by Frédéric Keck, Ann H. Kelly and Christos Lynteris, 102120. London and New York: Routledge, 2019.

Song, Huai-Dong, Chang-Chun Tu, Guo-Wei Zhang, Sheng-Yue Wang, Kui Zheng, LianCheng Lei, Qui-Xia Chen, Yu-Wei Gao, Hui-Qiong Zhou, Hua Xiang, Hua-Jun Zheng, Shur-Wern Wang Chern, Feng Cheng, Chun-Ming Pan, Hua Xuan, Sai-Juan Chen, HuiMing Luo, Duan-Hua Zhou, Yu-Fei Liu, Jian-Feng He, Peng-Zhe Qin, Ling-Hui Li, Yu-Qi Ren, Wen-Jia Liang, Ye-Dong Yu, Larry Anderson, Ming Wang, Rui-Heng Xu, Xin-Wei Wu, Huan-Ying Zheng, Jin-Ding Chen, Guodong Liang, Yang Gao, Ming Liao, Ling Fang, Li-Yun Jiang, Hui Li, Fang Chen, Biao Di, Li-Juan He, Jin-Yan Lin, Suxiang Tong, Xiangang Kong, Lin Du, Pei Hao, Hua Tang, Andrea Bernini, Xiao-Jing Yu, Ottavia Spiga, Zong-Ming Guo, Hai-Yan Pan, Wei-Zhong He, Jean-Claude Manuguerra, Arnaud Fontanet, Antoine Danchin, Neri Niccolai, Yi-Xue Li, Chung-I Wu, and GuoPing Zhao. "Cross-Host Evolution of Severe Acute Respiratory Syndrome Coronavirus in Palm Civet and Human." Proceedings of the National Academy of Sciences of the United States of America 102 (2005): 2430-2435.

Sontag, Susan. Illness as Metaphor and AIDS and Its Metaphors. London: Penguin, 2009. Stallybrass, Peter and A. White. "The City: The Sewer, the Gaze and the Contaminating Touch." In Beyond the Body Proper: Reading the Anthropology of Material Life, edited by Judith Farquhar and Margaret Lock, 266-286. Durham, NC: Duke University Press, 2007.

Stankiewicz, Damien. "Against Imagination: On the Ambiguities of a Composite Concept." American Anthropologist 118(4) (2016): 796-810. 
Starobinski, Jan. La relation critique (L'oeil vivant II). Paris: Gallimard, 2001 [1977].

Steger, Manfred B. and Paul James. "Levels of Subjective Globalization: Ideologies, Imaginaries, Ontologies." Perspectives on Global Development and Technology 12 (2013): 17-40.

Stein, Richard A. "Super-Spreaders in Infectious Diseases." International Journal of Infectious Diseases 15 (2011): e510-e513.

Stengers, Isabelle. In Catastrophic Times: Resisting the Coming Barbarism, translated by Andrew Goffey. London: Open Humanities Press, 2015.

St. John Mandel, Emily. Station Eleven. London: Picador, 2014.

Strauss, Claudia. "The Imaginary." Anthropological Theory 6 (2006): 322-344.

Strozier, Charles B. Apocalypse: On the Psychology of Fundamentalism in America. Eugene: Wipf and Stock, 2012.

Swift, John N. “Jack London's 'the Unparalleled Invasion': Germ Warfare, Eugenics, and Cultural Hygiene.” American Literary Realism 35(1) (Fall 2002): 59-71.

Swyngedouw, Erik. "Apocalypse Forever? Post-Political Populism and the Spectre of Climate Change." Theory, Culture \& Society 27(2-3) (March-May 2010): 213-232.

Taussig, Michael. Walter Benjamin's Grave. Chicago: The University of Chicago Press, 2006.

Taylor, Bryan C. "Nuclear Pictures and Metapictures." American Literary History 9(3) (Autumn 1997): 567-597.

Taylor, Bryan C. “'Our Bruised Arms Hung Up as Monuments': Nuclear Iconography in Post-Cold War Culture." Critical Studies in Media Communication 20(1) (2003): 1-34.

Taylor, Charles. Modern Social Imaginaries. Durham, NC: Duke University Press, 2003.

Taylor, George. "On the Cusp: Ricoeur and Castoriadis at the Boundary." In Ricoeur and Castoriadis in Discussion: On Human Creation, Historical Novelty and the Social Imaginary, edited by Suzi Adams, 23-48. Lanham: Rowman and Littlefield, 2017.

Thacker, Eugene. "The Shadows of Atheology, Epidemics, Power and Life after Foucault." Theory, Culture \& Society 26(6) (2009): 134-152.

Than, Ker. “'Zombie Virus' Possible via Rabies-Flu Hybrid.” National Geographic News, October 27, 2010 http://news.nationalgeographic.co.uk/news/2010/10/1001027-rabiesinfluenza-zombie-virus-science/

Thompson, Mark. "The Last of Us: 3 Key Observations to Understand the Ending." What Culture, November 30, 2013 http://whatculture.com/gaming/last-us-3-key-observationsunderstand-ending

Tomes, Arnaud. "Introduction à la pensée de Castoriadis." In Cornelius Castoriadis, L'imaginaire comme tel (texte etabli par Arnaud Tomes), 11-142. Paris: Hermann, 2007.

Tomes, Nancy. "The Making of a Germ Panic: Then and Now." American Journal of Public Health 90(2) (February 2000): 191-198.

Tomes, Nancy. "Epidemic Entertainment: Disease and Popular Culture in Early-TwentiethCentury America." American Literary History 14(4) (Winter 2002): 625-652.

Toscano, Alberto. "The Promethean Gap: Modernism, Machines, and the Obsolescence of Man.” Modernism/Modernity 23(3) (September 2016): 593-609.

Traverso, Ezno. Left-Wing Melancholia: Marxism, History, and Memory. New York: Columbia University Press, 2016.

Treichler, Paula. "AIDS, Homophobia and Biomedical Discourse: An Epidemic of Signification." Cultural Studies 1(3) (1987): 263-305.

Tsing, Anna L. The Mushroom at the End of the World: On the Possibility of Life in Capitalist Ruins. Princeton: Princeton University Press, 2015.

Tu, Changchun, Gary Crameri, Xiangang Kong, Jinding Chen, Yanwei Sun, Meng Yu, Hua Xiang, Xianzhu Xia, Shengwang Liu, Tao Ren, Yedong Yu, Bryan T. Eaton, Hua Xuan 


\section{Bibliography}

and Lin-Fa Wang. "Antibodies to SARS Coronavirus in Civets." Emerging Infectious Diseases 10(12) (2004): 2244-2248.

Tucker, Jennifer. Nature Exposed: Photography as Eyewitness in Victorian Science. Baltimore: Johns Hopkins University Press, 2013.

Upshur, Ross, Jerome Singh and Nathan Ford. "Apocalypse or Redemption: Responding to Extensively Drug-Resistant Tuberculosis." Bulletin of the World Health Organization 87 (2009): 481-483.

Van Dijk, Paul. Anthropology in the Age of Technology: The Philosophical Contribution of Gunther Anders. Amsterdam: Brill, 2000.

Van Eynde, Laurent. "La pensée de l'imagination de Castoriadis du point de vue de l'anthropologie philosophique." In L'imaginaire selon Castoriadis. Thèmes et enjeux, edited by Sophie Klimis and Laurent Van Eynde, 63-74. Brussels: Presses de l'Université Saint-Louis 2006.

Varlik, Nukhet. Plague and Empire in the Early Modern Mediterranean World: The Ottoman Experience, 1347-1600. Cambridge: Cambridge University Press, 2015.

Vermeulen, Pieter. "Beauty That Must Die: Station Eleven, Climate Change Fiction, and the Life of Form." Studies in the Novel 50(1) (Spring 2018): 9-25.

Verran, John, M. Crossely, K. Carolan, N. Jacobs and M. Avos. "Monsters, Microbiology and Mathematics: The Epidemiology of a Zombie Apocalypse." Journal of Biological Education 48(2) (2014): 98-104.

Virilio, Paul. Art and Fear. New York and London: Continuum, 2004.

Vox, Lisa. Existenial Threats: American Apocalyptic Beliefs in the Technological Era. Philadelphia: University of Pennsylvania Press, 2017.

Wagner-Lawlor, Jennifer A. "Performing History, Performing Humanity in Mary Shelley's the Last Man." SEL Studies in English Literature 1500-1900 42(4) (Autumn 2002): 753-780.

Wahab, Amar. Colonial Inventions: Landscape, Power and Representation in NineteenthCentury Trinidad. Cambridge: Cambridge Scholars Publishing, 2010.

Wald, Priscilla. "Cultures and Carriers: 'Typhoid Mary' and the Science of Social Control." Social Text 52/53 Queer Transexions of Race, Nation, and Gender (Autumn-Winter 1997): 181-214.

Wald, Priscilla. Contagious: Cultures, Carriers, and the Outbreak Narrative. Durham, NC: Duke University Press, 2008.

Wang, Ming and Bryan T. Eaton. "Bats, Civets and the Emergence of SARS." Current Topics in Microbiology and Immunology 315 (2007): 325-344.

Wang, Ming, Meiying Yan, Huifang Xu, Weli Liang, Biao Kan, Bojian Zheng, Honglin Chen, Han Zheng, Yanmei Xu, Enmin Zhang, Hongxia Wang, Jingrong Ye, Guichang Li, Machao Li, Zhigang Cui, Yu-Fei Liu, Rong-Tong Guo, Xiao-Ning Liu, Liu-Ha Zhan, Duan-Hua Zhou, Ailan Zhao, Rong Hai, Dongzhen Yu, Yi Guanand and Jianguo Xu. "SARS-CoV Infection in a Restaurant from Palm Civet." Emerging Infectious Diseases 11(12) (2005): 1860-1865.

Webley, Stephen J. "Wondering the Digital Wonderlands: The Interactive Images and Legends of Disaster: Desire and Ideology in Post-Apocalyptic Videogames." In Apocalyptic Chic: Visions of the Apocalypse and Post-Apocalypse in Literature and Visual Arts, edited by Barbara Brodman and James E. Doan, 211-228. Fairleigh: Dickinson University Press, 2018.

Webster, Joseph. "The Eschatology of Global Warming in a Scottish Fishing Village." Cambridge Anthropology 31(1) (March 2013): 68-84. 
Webster, Richard. "New Ends for Old: Frank Kermode's the Sense of an Ending." The Critical Quarterly (Winter 1974) www.richardwebster.net/kermode.html

Weisman, Alan. The World Without Us. London: Virgin Books, 2007.

Weiss, Harvey and Raymond S. Bradley. "What Drives Societal Collapse?" Science 291(5504) (26 January 2001): 609-610.

Wellcome Trust. "What Do We Do If a Pandemic Happens? The Science of the Last of Us." YouTube, September 26, 2016 www.youtube.com/watch?v=krnPbgMZdHI

Wells, Herbert G. “Zoological Retrogression.” 1891 https://en.wikisource.org/wiki/ Zoological_Retrogression

Wells, Herbert G. "The Extinction of Man." 1894 www.online-literature.com/wellshg/ certain-personal-matters/24/

White, Louise. Speaking with Vampires: Rumor and History in Colonial Africa. Berkeley, CA: The University of California Press, 2000.

Whitehall, Geoffrey. "The Aesthetic Emergency: The Avian Flu Effect." In Contagion: Health, Fear Sovereignty, edited by Bruce Magnusson and Zahi A. Zalloua, 71-98. Seattle: University of Washington Press, 2012.

Willerslev, Rane. Soul Hunters: Hunting, Animism, and Personhood among the Siberian Yukaghirs. Berkeley, CA: The University of California Press, 2007.

Williams, Joel. "These Zoo Animals Survived the Battle to Retake Mosul from ISIS." CNN, February 3, 2011, http://edition.cnn.com/2017/02/02/middleeast/iraq-mosul-zooanimals-trnd/index.html

Wills, John. "'Welcome to the Atomic Park': American Nuclear Landscapes and the 'Unnaturally Natural'." Environment and History 7(4) (November 2001): 449-472.

Wilson, Edward O. The Future of Life. New York: Knopf, 2002.

Wolfe, Nathan D., Ananias A. Escalante, William B. Karesh, Annelisa Kilbourn, Andrew Spielman and Altaf A. Lal. "Wild Primate Populations in Emerging Infectious Disease Research: The Missing Link?” Emerging Infectious Diseases 4 (1998): 149-158.

Woods, Abigail Angela Cassidy, Michael Bresalier and Rachel Mason Dentinger (eds.). Animals and the Shaping of Modern Medicine: One Health and its Histories. London: Palgrave Macmillan, 2017.

Worboys, Michael. Spreading Germs Disease Theories and Medical Practice in Britain, 1865-1900. Cambridge: Cambridge University Press, 2000.

World Health Organisation (WHO). Consensus Document on the Epidemiology of SARS, 2013 www.who.int/csr/sars/en/WHOconsensus.pdf

World Health Organization (WHO). List of Blueprint Priority Diseases, February 2018 www.who.int/blueprint/priority-diseases/en/

World Health Organisation (WHO), Department of Communicable Disease Surveillance and Response. Consensus Document on the Epidemiology of Severe Acute Respiratory Syndrome (SARS) Produced by the Severe Acute Respiratory Syndrome (SARS) Epidemiology Working Group and the Participants at the Global Meeting on the Epidemiology of SARS, 16-17 May 2003 www.who.int/csr/sars/en/WHOconsensus.pdf

Wu Lien-teh, W. H. Chun and Roger Pollitzer (eds.). Plague: A Manual for Medical and Public Health Workers. Shanghai: National Quarantine Service, 1936.

Yang, Sarah. "Small Groups of Superspreaders Lead Most Infections, New Study Says." UC Berkeley Press Release, November 16, 2005 https://www.berkeley.edu/news/media/ releases/2005/11/16_super.shtml

Yar, Majit. Crime and the Imaginary of Disaster: Post-Apocalyptic Fictions and the Crisis of Social Order. London: Palgrave Macmillan, 2014. 
Yersin, Alexandre. "La peste bubonique à Hong Kong." Annales de l'Institut Pasteur 8 (1894): 662-667.

Zambon, Maria and Karl G. Nicholson. "Sudden Acute Respiratory Syndrome May Be a Rehearsal for the Next Influenza Pandemic." British Medical Journal 326 (2003): 669-670.

Zand, Sahar. "The Animals Rescued from War Zones." BBC News, August 31, 2017 www. bbc.co.uk/news/av/world-middle-east-41104849/the-animals-rescued-from-war-zones

Zhan, Mei. "Civet Cats, Fried Grasshoppers, and David Beckham's Pajamas: Unruly Bodies after SARS." American Anthropologist N.S. 107(1) (March 2005): 31-42.

Zheng, C. "Relevance of Traditional Wet Markets, as a Communal Space that Promotes Community Bonding, in Singapore's Public Housing Estates." Asian Urban Epicenters: Collaborative Platform for Sharing Thoughts on Asian Urbanism htpp:// asianurbanepicenters.com/?p=1734

Žižek, Slavoj. How to Read Lacan. London: Granta Publications, 2006.

\section{Filmography}

Amiel, Jack and Michael Begler (dirs.). The Knick. Culver City: Anonymous Content, 2014.

Bergman, Ingmar (dir.). The Seventh Seal (Det Sjunde Inseglet). Stockholm: AB Svensk Filmindustri, 1957.

Boyle, Danny (dir.). 28 Days Later. London: DNA Films and the British Film Council, 2002.

Buñuel, Luis (dir.). Simon of the Desert (Simón del desierto). Mexico City: Gustavo Alatriste, 1965.

Carter, Chris and Kim Manners (dirs.). The X Files. Los Angeles, CA: 20th Century Fox Television, 1993.

Cuarón, Alfonso (dir.). Children of Men. Hollywood: Strike Entertainment, 2006.

Darabont, Frank (dir.). The Walking Dead. American Movie Classics, 2010.

del Toro, Guillermo and Chuck Hogan (dirs.). The Strain. Hollywood: FX Productions, 2009.

Fong, Norhaya A. A Tale of Two Esthers. Singapore: IMprint Media, 2015.

Foster, Marc (dir.). World War Z. Hollywood: Paramount Pictures, 2013.

Francis, Freddie and Steven Sekely (dirs.). The Day of the Triffids. London: Allied Artists Pictures and Security Pictures, 1962.

Garris, Mick (dir.). The Stand. Hollywood: Greengrass Productions, Laurel Entertainment Inc, 1994.

Gilliam, Terry (dir.). Twelve Monkeys. Hollywood: Universal Pictures, 1995.

Godard, Jean-Luc (dir.). Weekend (Week-end). Paris: Athos Films, 1967.

Kazan, Elias (dir.). Panic in the Streets. Hollywood: 20th Century Fox, 1950.

Lawrence, Francis (dir.). I Am Legend. Hollywood: Warner Bros. Pictures, 2007.

Lindelof, Damon and Tom Perrotta (dirs.). Leftovers. Hollywood: Warner Bros. Television \& HBO Entertainment, 2014.

Matalas, Terry and Travis Fickett (dirs.).12 Monkeys. Los Angeles, CA: Atlas Entertainment, 2015.

Petersen, Wolfgang (dir.). Outbreak. Warner Bros. Pictures, 1995.

Romero, George (dir.). Day of the Dead. Hollywood: Dead Films Inc., Laurel Entertainment Inc., 1985.

Scott, Ridley (dir.). Alien. Hollywood: 20th Century Fox, 1979. 
Soderbergh, Steven (dir.). Contagion. Hollywood: Warner Bros. Pictures, 2011.

Straley, Bruce and Neil Druckmann (dirs.). The Last of Us. Santa Monica, CA: Naughty Dog, 2013.

Sturges, John (dir.). The Satan Bug. Mirisch Corporation, 1965.

Tarr, Béla (dir.). The Turin Horse (A torinói ló). Budapest: T. T. Filmmühely, 2011.

Vaughan, Brian K. (dir.). Under the Dome. Los Angeles, CA: CBS Television Studios, 2013.

Visconti, Luchino (dir.). Death in Venice (Morte a Venezia). Rome: Alfa Cinematografica, 1971.

von Trier, Lars (dir.). Epidemic. Copenhagen: Elementfilm A=S, Det Danske Filminstitut, 1987.

Wise, Robert (dir.). The Andromeda Strain. Hollywood: Universal Pictures, 1971.

Wyatt, Rupert (dir.). Rise of the Planet of the Apes. Hollywood: 20th Century Fox, 2011. 


\section{Index}

Abraham 111

Adams, Suzi 22n82

Adorno, Theodor 9, 13, 14

Aeschylus 16, 90, 91, 98n77, 128

Africa 30, 56, 74n86, 100-101; West Africa 64, 73n72

Agamben, Giorgio 9, 27, 30, 35, 44, 74n88

Amritsar massacre 66

Anders, Günther 1, 31-32, 40n53, 40n54, 137

Anderson, Warwick 47

anomy xi, 15, 27-32, 35-36, 103, 118, 120,130 n 12,136 ; mystery of $30,35-36$ anthrax 64

Anthropocene 1, 2, 4, 25, 137, 138, $143 n 16,143 n 17$

anthropogenesis $5,13,16,35,77-98,106$, 126

anticipation $\mathrm{x}, 2,9,14,16,25,29,54,60$, 99, 129, 137, 141

Antigone 92

antimicrobial resistance (AMR) 4, 7

apocalypse xi, 8, 15, 24-41, 106, 139; apocalyptic potential $8,15,25,26$,

$36,37 \mathrm{n} 2,89$; apocalyptic structure

27-30; apocalyptic tone 89; blindness

to 31 ; eschaton $8,27-30,32,35,118$;

katechon 15, 27-30, 35, 39n28, 118;

and Kingdom 15, 26, 29; parousia 27,

32 ; perdition $28,103,125-128$; post-

apocalypse/post-apocalyptic $17,31,118$, 119, 126, 129; and revelation 24, 26;

see also anomy; eschatology; time;

world, end of

Apollo Smyntheus 50

Arkhipov, Vasili Alexandrovich 40-41n57

Arnold, David 123-124

Artaud, Antonin 103

Asayama, Shinichiro 139

Asclepius 67
Atamanovka 77

autonomy and heteronomy $11,13,22 \mathrm{n} 82$, 23n96, 139, 140-141, 142

autopoiesis (self-creation) xi, 11-13, 17, 92, 128-129, 135n76, 140-142

Babel 111

bacteriology 45, 46, 48, 49, 64, 66, 80

Baldwin, Charles 42

Barthes, Roland 66, 69

bat $56,64,102$

Baudrillard, Jean 31

Beck, Ulrich 139

Benjamin, Walter xii, 9, 14, 44, 54, $75 \mathrm{n} 102,88,122,137,138,143 \mathrm{n} 16$

Berger, James 118

Bergman, Ingmar 100

bicorporate 42

biodiversity 2,4

biopolitics 4, 6, 7, 9, 13, 16, 25, 35, 44, 45, $46,48,53,54,57,63,67,78,79,80$, 82-87, 92-93, 100, 105, 108, 110, 112, $115 \mathrm{n} 29,117 \mathrm{n} 51,137,138$

biosecurity $34,57,60,85,86,138$

Blagoveshchensk 77

Boccaccio, Giovanni 103

Bond, Henry 65

Bostrom, Nick 4

Boyle, T. C. 121, 126

Brassier, Ray 119

Breton, André 23n104

Brown, Hannah 83

Brown, Wendy 58, 143n16

Bruzzone, Rachel 122

Buck-Morss, Susan 14, 123, 126

Buell, Lawrence 137

Bull, Malcolm 122

Buñuel, Luis 131n26

burial $6,28,65$

bushmeat $74 \mathrm{n} 86$ 
Cacciari, Massimo 27

Caduff, Carlo 7, 8, 25, 33, 57, 59, 67, 69n9

Caillois, Roger 113

camouflage 109, 112

capitalism 4, 5, 31, 36, 88, 92, 124; capitalist realism 136, 138, 142n1; disaster capitalism 25

Casel, Odo 35

Castoriadis, Cornelius 10-13, 21n68, 21n80, 22n81, 22n82, 23n96, 28, 87, 90-92, 129, 135n76, 139-142, 144n31; see also imaginary

catastrophe 4, 5, 15, 16, 26, 29, 31, 33, $4 \ln 57,97 \mathrm{n} 72,118,122-123,126$, $13 \ln 27,138$; equivalence 123,138 catastrophism 17, 136-142; enlightened 137; normative 24, 25, 137, 141

Camus, Albert 100

Chamayou, Grégoire 16, 111

Chernela, Janet 3-4

China 47, 48, 62-64, 77-78, 84-85

Chinese Medical Association 85

Chita 77

city, empty 122,127

climate change $1,2,8,24,25,26,38 \mathrm{n} 17$, 40n55, 56, 59, 119, 139, 144n35

collapse 15-16, 119, 126-129, 130n12; social 28; societal 56, 103, 120, 135n74; stock market 87,88

colonial/colonialism $3,35,46,47,48,63$, $66,123-125$

commodity 104

contagion $16,63,78,81,86-88,92$, 97n71, 100, 101, 106; see also film corpse $6,28,39 \mathrm{n} 33$

cosmology (mythocosmological) 5, 16, 25, $36,44,67,99,113,121,125$

cosmopolitanism 138, 139

Creel, R. H. 47

Cronon, William 125

culture $2,6,10,12$; culture hero 16,89 , 99-117; cultural vector 33; see also nature

cybernetics $49,59,72 \mathrm{n} 41$

Danowski, Déborah 1, 13, 15, 27, 31, 33, 39n39, 125

Darwin, Charles 3

Darwinism 110, 119, 124; Social Darwinism 127

Dawsey, Jason 31

DDT 51, 53, 54, 58

degeneration $3,125,133 \mathrm{n} 50$

Deleuze, Gilles 53, 106

Derrida, Jacques 26
Descola, Philippe 15, 19n25, 53, 126

Diagnosis 67-68

diagram 15, 45, 65, 69, 81, 79-91; Disease Diagram 53-54, 57-59, 62; spidergram 59-61; zoonotic cycles 49-53, 57, 58, $59,71 \mathrm{n} 36,72 \mathrm{n} 39,72 \mathrm{n} 40,72 \mathrm{n} 44$

dialectics 51, 59, 112, 123, 141, 143n16

Diamond, Jared $135 \mathrm{n} 74$

Dick, Philip 119

disaster 1, 122-123, 138; see also capitalism

disinfection 57, 78

Dodds, Eric 68

Dosse, François $21 \mathrm{n} 68$

Dupuy, Jean-Pierre 31, 41n57, 137, 139

Durkheim, Émile 28

Ebola x, 7, 33, 34, 42, 56, 59-61, 64, 69n3, 73n72, 83, 100-101, 104, 115n21, $117 \mathrm{n} 57$

ecology, disease $6,48,49,64$

economy: political 5, 16, 25, 62, 78, 86-87, $92,104,115 \mathrm{n} 29,143 \mathrm{n} 17$; visual 65

Eden (Edenic) 125-128

Edmond, Rod 125

emergency $61,88,97 \mathrm{n} 71,104$

emptiness 128

end, the; see also time; world

electromagnetic pulse (EMP) 4, 24

entanglement 57-62

environmentalism 125

enzootic 51

epidemiology: epidemiological reasoning $6,16,34,45,48,49,53,60,78,80,82$, $85-86$; material proximities $83,84,86$; see also culture, culture hero epistemology 1, 15, 45, 79, 124 epizootic 51

eschatology xi, 15, 25, 29, 37n3

Esposito, Roberto 27, 138

exchange, value $103,12 \ln 26$

Faubion, James 25-26, 29

festival: Dragon*Con 104

film: 28 Days Later 106, 109; Alien 110;

The Andromeda Strain 100, 104, 105;

The Book of Eli 121; A Boy and His Dog

121; Contagion 8, 63, 93n11, 101-104, 105; Death in Venice 100; Day of the

Dead 106; I Am Legend xi, 74n86, 108, 121, 123; Outbreak 42, 56, 58, 100-102, 114n6; The Planet of the Apes (1968) 115n22, 131n26; The Seventh Seal 100; Simon of the Desert 131; 


\section{Index}

Twelve Monkeys 104, 132n36; Weekend 130n12; World War Z x, 58, 105-106, 108-113, 116n40, 117n51

Fischer, Michael 98n85

Fisher, Mark 136, 142n2

flea $46-51,110$

Florence 103

Fœssel, Michaël 17, 67, 137-138

Foucault, Michel 53, 66, 68, 111

Frazer, James 87

Fukushima 1, 138

fumigation $46,54,58$

functionalism $8,37 \mathrm{n} 2,141,142$

funeral 28, 33

future $x, 2,3,8,12-13,17,25,31-34$, $36,56,65-68,101-102,126-128,136$, 141-142; non-future $\mathrm{x}, \mathrm{xi}, 79,92,118$

\section{Galen 67-68}

Garrett, Laurie 7, 39n41, 55, 62, 73n63, 114

Gates, Bill 57, 73n67

Gerlach, Neil 2

Gilgamesh 99

Global Health x, 54, 55, 88

globalization 4, 45, 55

global warming 4,5

Godard, Jean-Luc 130n12

Gomel, Elana 8-9, 26, 29, 105

Guandong 80

Guattari, Felix 106

Hamilton, Sheryl 2

Harrison, Mark 35

Hasian, Marouf 69

Heilongjiang 77

Heise, Ursula 4

Hesiod 68, 97-98n74

Himalayas 70n19

Hinchcliffe, Steven 53, 57

Hiroshima 31-32, 101

HIV/AIDS 64, 101, 110

Holbraad, Martin 12, 141

Hollywood x, 1, 8, 58, 93n11, 100, 101, $103,110,114 \mathrm{n} 6$

Hong Kong 46, 62, 63, 64, 80-84, 103-104

hope $9,29,32,40 \mathrm{n} 57,58,66,93,108$, 126, 141; blind 90

Horkheimer, Max 9

hospital: Prince of Wales Hospital 83-84, 86

Hughes Fowler, Barbara 90

human/nonhuman relations $6,8,9,13,14$, $15,16,45,54,58,59,62,66,68,88,142$ von Humboldt, Alexander 124 humors $68,13 \ln 30$ hunting 59, 65, 74n86, 110, 123, 130n19; man-hunting 111-113, 117n53

hygiene 62; see also modernity

ignorance 89, 123

imaginary: and anthropology $12,22 \mathrm{n} 86$, 22n109; civic 28; creative 22n81, 87; instituted vs instituting $10,11-13,17$, $128,129,136,139-140,141$; nuclear 121-122; pandemic 10-15, 17, 23n99, $26,29,30,33,34,35,36,44,45,54,57$, $59,62,64,69,78,81,92,98 \mathrm{n} 82,99$, $100,103,112,114,118,119,120,123$, $125,127,128,129,139,141$; social 12 , 13, 21n68; technoscientific 12

imagination 10-12, 31, 40n54, 87, 124, $136,139,141$; imagination-deficit 31-32

immunology 6, 34, 113, 117n49

India 46, 70n19, 108-109, 112

infection $6,16,48-51,53,57,59,65,69$, $79,81,82-83,108,109,112-113$

influenza 8, 25, 42, 64, 77, 104, 142n3; Spanish Flu 56

infrastructure 47, 78, 81, 83-84, 86, 92, 96n57

Ingold, Tim 12, 142

invisibility 15, 34, 65-68, 108

isolation 77,85

Japan 48

Jerusalem 58, 108, 111

John Chrysostom 27

Jonas, Hans 1

jungle 58, 66, 121, 130n17, 133n49

Kabbalah 111

Kant, Immanuel 12

Keck, Frédéric 8, 15, 59, 67, 72n44

Keller, Catherine 78

Kelly, Ann 83

Kermode, Frank 26, 37n2

Khan, Ali S. 66, 81, 104, 106, 132n33

Kiku, Adato 101, 102

King, Nicholas 6-7, 55

kinship 102, 129

Klapp, Orrin 99

Klooger, Jeff 140-141

Koch, Robert 64

Kremlin 5

laboratory 71,101

Lacan, Jacques 10, 21, 26, 65

Lachenal, Guillaume 74n86

Lakoff, Andrew 59, 67, 87 
Larson, William 99

Latour, Bruno 65

Lawrence, Francis 108, 121

Leach, Neil 112

Leakey, Richard 2

Lederberg, Joshua 7, 55, 59, 100

Leslie, John 4

Lévi-Strauss, Claude 8, 9, 20n51, 87, 109

Lewin, Roger 2

listeria $75 n 99$

Liu, Sze-ki 62

Lloyd-Smith 82, 85

London, Jack 35, 127-128, 134n66

looting 103, 120

mad cow disease 8, 20n51

Mallon, Mary (Typhoid Mary) 79-80

Manchuria 47, 48, 78

Mandel, Emily St. John 128

Manson, Patrick 124

Maoism 89

market, wet 30, 62-64, 68

Martino, Ernesto de 31, 32, 40n46, 41n58

Marxism 89, 138

Masco, Joseph 33, 122, 126

mask (masking) 42, 102, 112, 117n49

mastery $1-23,27,28,30,32,33,35,36$, $45,54,58,66,69,88-92,104,105$, $118-120,124,125,126,128,129$, $133 n 42,139,141,142$

Mauss, Marcel 21n80

Meillassoux, Quentin 119

melancholia 122; left 138, 141, 143n16

messianism 89, 97n71

Meyer, Karl F. 3, 49

miasma 124, 133n 47

microscope 8, 34, 64-66

Middle East Respiratory Syndrome (MERS) 34, 81, 96n57

Milan 94n18

modernity 14,56 ; hygienic $46,48,58,62$, $87,88,97 \mathrm{n} 68,125,137$

Morse, Stephen S. 6, 7, 55, 59

Morton, Timothy 32, 137

Moscow 77

Mossad 108-109, 113

mutation (mutant) 7, 25, 35, 42, 67, 101, $127,132 \mathrm{n} 33$

Myerhoff, Barbara 99

Myers, Norman 2-3

myth/mytheme/mythic $4,5,8,9,13,14$, $15,16,25,27,19,30,32,33,35,36$, $44,58,63,67,78,79,80,81,87-93$, 100, 106, 109, 114, 122; see also cosmology
Nagasaki 31-32

Nancy, Jean-Luc 17, 87, 122-123, 138, $143 \mathrm{n} 17$

Napier, A. David 113, 117n49

Narat, Victor 54, 61

Nardelli, Matilde 26, 121

nature: and culture 17, 19n26, 53, 91, 104, 113, 126-127; human 5, 15, 16, 35, 36, 141, 142; see also ontology; rewilding

Navaro, Yael 122

New York 108, 122, 123, 127; Manhattan 108, 120-121, 130; Times Square 123, 127,130 n 19

Nimrod 111

North Korea 109, 111-113

nuclear: catastrophe 1, 4, 9, 15, 31-33, 32, 121; Cuban Missile Crisis 41n57; postnuclear 17, 121-123, 126; winter 32; see also imaginary

Oedipus 8, 122

Okely, Judith 23n104

One Health 36

ontology $1,2,6,7,9,10,16,17,22 \mathrm{n} 86$, $25,27,31,35,36,44,45,48,53,54,55$, $57,59,60,63,67,69,88,91,92,100$, $103,105,109,110,112,113,119,120$, $125,128,129,142$; naturalist $19 \mathrm{n} 26,53$, 91, 126, 127; political 11, 13, 29, 36, $139,141,142$

Orwin, Clifford 28

Ostherr, Kirsten 42, 100-101, 115n21

outbreak narrative $7,8,81,104$

Page, Max 122

panic 77

parrhesia (truth-telling) 68

Pasteur, Louis 67, 113

Paul, St. 14, 27, 30

Pausanias 122

Pavese, Cesare 9

Peckham, Robert 77, 94n23, 116n41

Pedersen, Morten Axel 12, 141

Pentagon 5

Pericles 28-29

Petersen, Wolfgang 42, 56, 100

phantasmagoria 123,126

phenomenology $81,140,144 \mathrm{n} 31$

photography x, xi, $15,28,45$; epidemic 46 , 64-66, 68; prophetic 66-69; see also plague

Pinney, Christopher 66

pirate 44

plague xi, $8,16,28,34,45-52,53,56,58$, 64-66 


\section{Index}

Poe, Edgar Allan 35

poetics 9

Poirier, Nicolas 140

posthumanism 31

Poussin, Nicolas 122-123

precaution $25,85,93$

preparedness, pandemic $1,7,8,13,16$, $23 \mathrm{n} 99,25,30,35,44,57,59,67,79,85$, 86, 104, 106

Preston, Richard 7, 39n41, 55, 56, 62, 69n $4,73 n 78,100$

prevention 15, 30, 51, 55, 58, 59, 92

Prometheus 16, 89-91, 97-98n74, 98n77; anti-Prometheus 78, 86-92; Prometheanism 4, 97n73, 105; Promethean gap 31, 40n53

prophecy: Delphic oracle 68; medical 68; pandemic 8-9, 16, 25, 29-30, 61, 62, 66-67, 69; see also photography public health $\mathrm{x}, 7,24,47,49,55,82,84$, $86,87,93 \mathrm{n} 11,102$

Quammen, David 56, 59, 61-62, 63, 67 quarantine $46,78,85,120$

rabies $45,106,109$

ragpicker 14, 23n104

rat 46-51, 59, 63, 66; Danysz virus 47; deratization $46,70 \mathrm{n} 25$; rat-proofing 46 , $51,53,54,57$

Rees, Martin 16n33

Renaissance 50, 122, 134n 54

reservoir, disease $6,47,51,53,56,64$; pathogen maintenance 49

revolution $87,89,97 \mathrm{n} 72,103,112$

rewilding $17,120-125,126,135 \mathrm{n} 71$

Rheinberger, Hans-Jörg 49

Riffel, Casey 119, 129

risk, existential xi, xii, 1, 4, 5, 24, 25, 35, 41n61, 45, 73n67, 81, 99, 113, 136, 137, 139

ritual $4,8,32,126$

Robinson, Tony 127

Rodwell, James 46

Rogaski, Ruth 46, 48, 58

Romanticism 8, 14, 31, 125

Rome 118-119

Romero, George 91, 105

Rosaldo, Renato 2

ruins/ruination $31,32,121-123,126$, $13 \ln 26,141$

Russia 47, 48, 77-78

sacrifice 9, 19, 93; self-sacrifice 103

salmonella 75

Samimian-Darash, Limor 59
Sartre, Jean-Paul 10-11

Schmitt, Carl 27, 39n28

Schuster, Joshua 119

science fiction (SF) 2, 18n12, 24, 32, 35, 104, 105, 119

Scott, Ridley 110

Scranton, Roy 25

Sebastian, St. 50

sentinel 7, 57, 67, 69

seriality 33-34

Serres, Michel 113

serum 101,108

Severe Acute Respiratory Syndrome (SARS) x, 7, 16, 33, 34, 45, 63, 64, 77-78, 80-85; Amoy Gardens 83, 84, 86; Metropole Hotel 80, 81, 83; see also superspreader

Severi, Carlo 15

Shaviro, Steven 105

Shelley, Mary 8, 35

Siberia 47, 77, 117n53

signification 14, 17, 21n68, 141; floating signifier $62,69,110$

Simond, Paul-Louis 46

simulation 31

Singapore $63,94 \mathrm{n} 19$

Singh, Julietta 120

Sinoe 33

smallpox 53, 109

Smith, Shawn Michelle 65-66

Sneath, David 12, 141

Soderberg, Steven 63

Sodikoff, Genese 2

Sophocles 8, 92, 98n84, 122

South Africa 47, 70

sovereignty $27,29,58,109,111,113,130 \mathrm{n} 12$

speciation 119,129

species-being 3, 15, 32, 33, 88, 109, 120

spillover $6,7,35,44,56,57,59,60,62$, 63, $75 \mathrm{n} 99$

Stalinism 89

stasis 32

Stone Age 126

Strauss, Claudia 10

superspreader 16, 77-98, 106, 110

surveillance $7,34,57$

suspension 129, 140, 144n30

Swyngedouw, Erik 26

symbolic 4, 5, 10, 11, 21n68, 42, 50, 62, $63,64,67,68,69,104$

Tarde, Gustave 87

Tarr, Bela 32-33

Taussig, Michael 88

Taylor, Charles 12

techne 16, 89-91, 128, 135n73 
technology 4, 5, 12, 54, 91, 99, 135n73; of power, pastoral CF cynegetic 111

Thacker, Eugene 53

theology, political 28, 112

Thucydides xi, 12, 28, 103, 122

time $8,15,25-36,51,67,83,85,97 \mathrm{n} 71$, $101,105,118,122$; time of the end CF end of time 15, 26, 27-30, 31, 36

Tomes, Arnaud 10

Toren, Christina 142

totalitarianism 5,112

von Trier, Lars 100

tropics 34, 58, 100, 123-125; tropicalization $123,125,128$

Tsing, Anna 31

Tucker, Jennifer 64-65

TV shows: Cordon 120; The Leftovers 136, 142n3; The Stand 136, 142n3; The Strain 44; The Twelve Monkeys 6; The Twilight Zone 122; Under the Dome 136, 142n3; The Walking Dead 106, 108, 136 typhus 34

unconscious: collective 10; optical 65, $75 \mathrm{n} 102$

United States (USA) 7, 41n57, 47, 79, 100 101

US Centers for Disease Control and Prevention (CDC) 7-8, 16, 29-30, 33, 34, 44, 57, 66, 73n72, 80, 81, 102, 104, 106-108, 115n20, 116n33, 132n33

utopia/utopianism 3, 32, 40n57, 91, 125 , 126; sanitary-utopianism $16,51,53,57$, $58,59,62$

vaccine $102-105,108-109,112$

videogames $\mathrm{x}, 18 \mathrm{n} 12,37 \mathrm{n} 6,106,132 \mathrm{n} 33$; The Last of Us xi, 123, 130n19, 132n33 viral/virality $16,36,88,91,92,97 \mathrm{n} 69$

Virilio, Paul 89

virulence 35,124

virus: killer $\mathrm{x}, 16,30,44,88,90,100$, $102,125,132 \mathrm{n} 36$; hunters 61 ; viral indeterminacy 67

Visconti, Luchino 100

Viveiros de Castro, Eduardo 1, 9, 13, 15 , $27,31,33,39 n 39,125$

vortex 42,44

Wald, Priscilla 7-8, 79, 80, 81, 94n19

War: Cold War 1, 5, 31, 45, 121, 122; Peloponnesian 28; Syria 132n35; Yugoslavia 132n35; see also nuclear

Weisman, Alan 125

Wells, H. G. 3

Wolfe, Nathan $61,74 \mathrm{n} 86$

World: end of $1,4,8,9,15,17,24-41$, $42,43,44,67,69,78,92,99,106,113$, $115 \mathrm{n} 22,125,130 \mathrm{n} 12,131 \mathrm{n} 26,132 \mathrm{n} 33$, 133n49, 136, 137; loss in/of 17, 79, 93n10, 118, 128-129, 137-139

World Health Organization (WHO) 30, 33, $45,57,80,83,103-104,110$

Yersin, Alexandre 46

Zaire 62, 101, 115n21

Zanchi, Antonio 123

Zhan, Mei 63

Zohar 111

zombie (living-dead) x, xii, 8, 16, 37n1, 58, 91, 98n $82,105-113,115 \mathrm{n} 29$, $115 \mathrm{n} 30,117 \mathrm{n} 59$

zoo $123,132 \mathrm{n} 35$

zoonosis xii, 1, 6, 8, 15, 35, 42-76, 101, 106, 130n17 


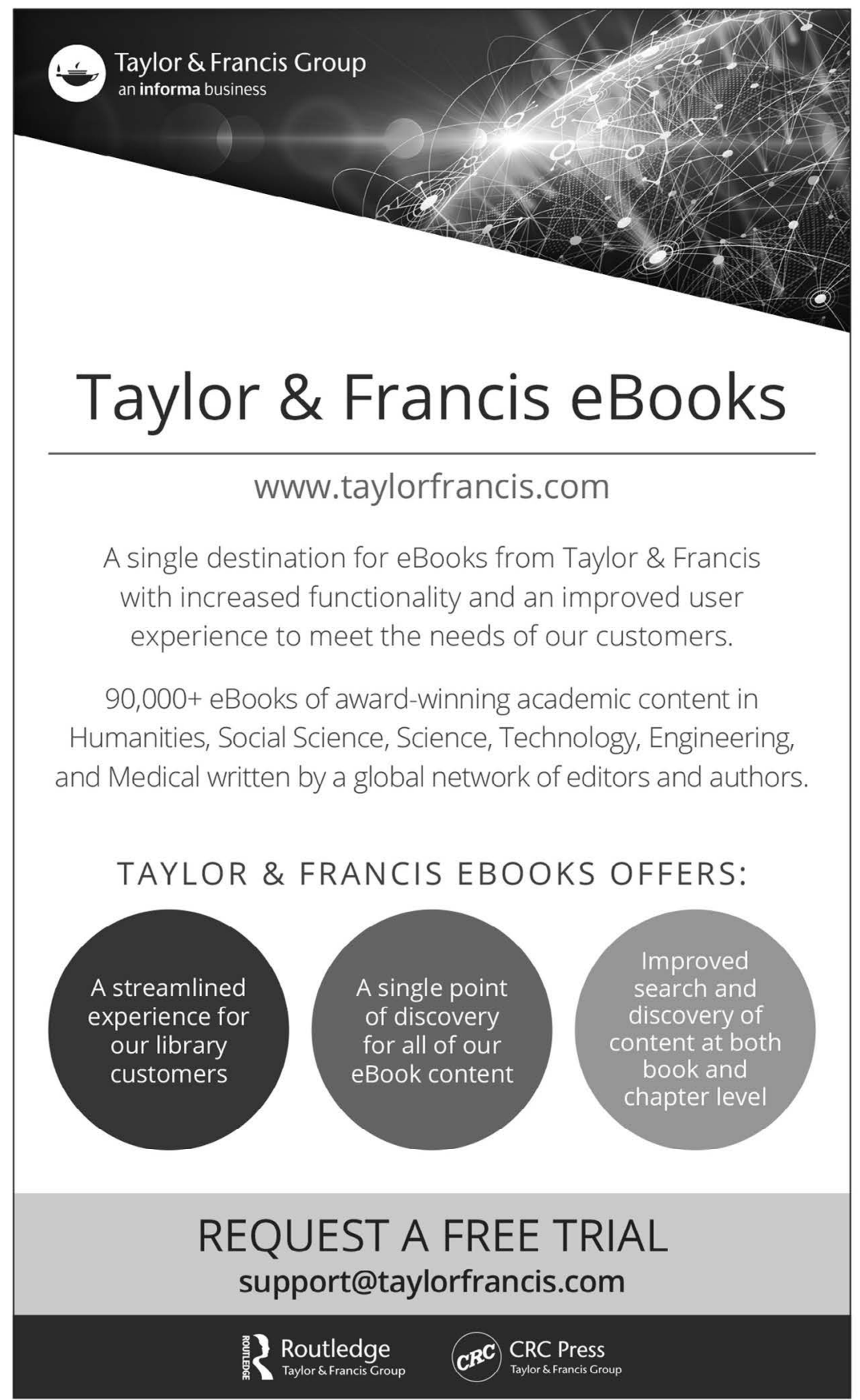

